AUG 201990

Compliments of Dr. \& Urs. Newell E. Good

Technical Series, No. 27, Part I.

U. S. DEPARTMENT OF AGRICULTURE, BURFAU OF FNITOMOIAGI'

L. O. HOWARD, Entomologist and Chief of Bureau.

\title{
CLASSIFICATION OF THE ALEYRODIDE.
}

PART I.

BY

A. L. QUAINTANCE,

In Charge of Ineciduous Fruit Insect Investigations.

AND

A. C. BAKER,

Expert.

IsSUEd MARCH 6, 1913.

WASHINGTON:

GOVERNMENT PRINTING OFFIOE.

1913. 

Technical Series, No. 27, Part 1.

U. S. DEPARTMENT OF AGRICULTURE) BUREAU OF ENTOMOLOGY.

L. O. HOWARD, Entomologist and Chief of Bureau.

\section{CLASSIFICATION OF THE ALEYRODIDE! PART I.}

BY

A. L. QUAINTANCE,

In Charge of Deciduous Fruit Insect Investigations.

AND

A. C. BAKER,

Expert.

Issued March 6, 1913.

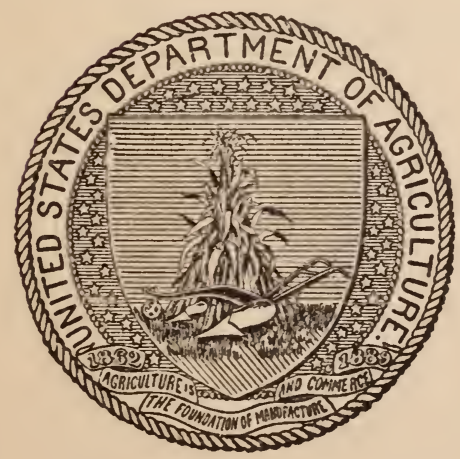

WASHINGTON:

GOVERNMENT PRINTING OFFIOE.

1918. 


\section{BUREAU OF ENTOMOLOGY.}

L. O. HowARD, Entomologist and Chief of Burcau.

C. L. MarlatT, Entomologist and Acting Chief in Absence of Chief.

R. S. Clifton, Executive Assistant.

W. F. TAstet, Chief Clerk.

F. H. ChitTenden, in charge of truck crop and stored product insect investigations.

A. D. HopkINs, in charge of forest insect investigations.

W. D. Hunter, in charge of southern field crop insect investigations.

F. M. WEBSTER, in charge of cercal and forage insect investigations.

A. L. QUAINTANCE, in charge of deciduous fruit insect incestigations.

E. F. Phillips, in charge of bee culture.

D. M. Rogers, in charge of preventing spread of moths, field woork.

Rolla P. CurRie, in charge of editorial work.

MaBel Colcokd, in charge of library. 


\title{
LETTER OF TRANSMITTAL.
}

\author{
U. S. Department of Agriculture, \\ Buread of Entomology, \\ Washington, D. C., August 14, 1912.
}

Sir: I have the honor to transmit herewith for publication as Technical Series No. 27, Part I, of this bureau a manuscript dealing with the insects of the family Aleyrodidæ, or white flies. This family includes several species of insects of the greatest economic importance, and other species are attracting attention by reason of their increasing abundance and injuries. The bureau is therefore frequently called upon to determine these insects, not only from this country but from many parts of the world. This family has been much neglected by entomologists and there has thus not been established a system of classification for the various forms. It is the aim of the present paper to furnish this needed system of classification, which, it is believed, will be found most useful to those interested in the family. Part II will contain an account of the species of the large and important genus Aleyrodes and will complete the monograph of the family.

Respectfully,

L. O. Howard,

Entomologist and Chief of Bureau.

Hon. James WiLson,

Secretary of Agriculture. 
Digitized by the Internet Archive in 2013 


\section{CONTENTS.}

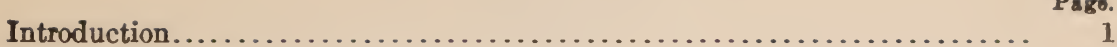

Morphology of the Aleyrodidæ................................ 2

Classification.................................................. 16

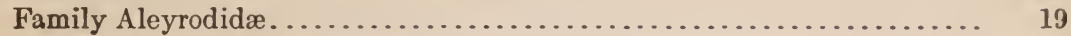

I. Subfamily Udamoselinæ.......................... 20

Genus Udamoselis.................................. 20

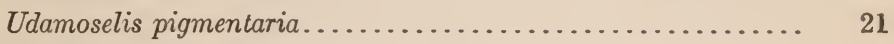

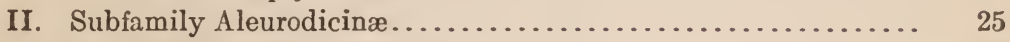

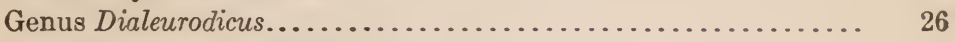

Dialeurodicus cockerellii........................ $\quad 26$

Dialeurodicus silvestrii.......................... 28

Dialeurodicus tessellatus........................ $\quad 30$

Dialeurodicus pulcherrimus......................... 31

Genus Leonardius.................................. 33

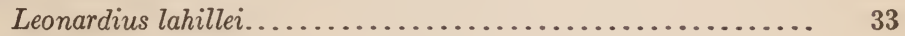

Genus Aleurodicus............................... 41

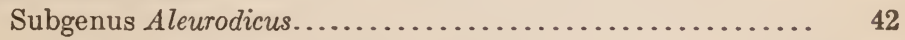

Aleurodicus anonæ.............................. 44

(Aleurodicus) Aleyrodes asarumis................. $\quad 45$

Aleurodicus coccolobæ......................... $\quad 46$

Aleurodicus cocois......................... 47

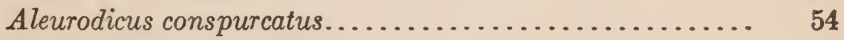

Aleurodicus destructor.......................... $\quad 56$

Aleurodicus dugesii............................ $\quad 57$

Aleurodicus guppyii.......................... $\quad 59$

Aleurodicus jamaicensis....................... 60

Aleurodicus holmesii.......................... 61

Aleurodicus neglectus......................... 63

Aleurodicus ornatus............................ 65

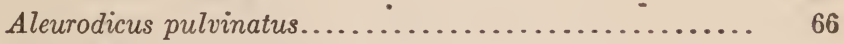

Aleurodicus trinidadensis..................... 69

Subgenus Lecanoideus......................... $\quad 70$

Aleurodicus (Lecanoideus) giganteus................. $\quad 70$

Aleurodicus (Lecanoideus) mirabilis ................ $\quad 72$

Subgenus Metaleurodicus....................... $\quad 73$

Aleurodicus (Metaleurodicus) altissimus............. 73

Aleurodicus (Metaleurodicus) cardini................. $\quad 75$

Aleurodicus (Metaleurodicus) minimus............... $\quad 77$

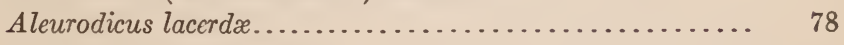

Aleurodicus phalænoides...................... $\quad 79$

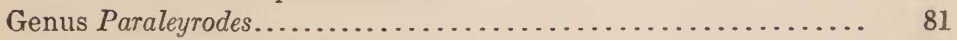

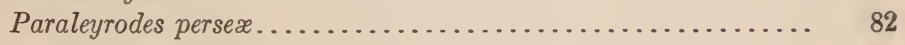

Paraleyrodes urichii........................... 83

III. Subfamily Aleyrodinæ.......................... 84

Genus Aleurochiton................................. 85

Aleurochiton aceris.............................. 85

Aleurochiton forbesii.............................. 88

Genus Aleyrodes.................................. 91

Genus Neomaskellia.............................. 91

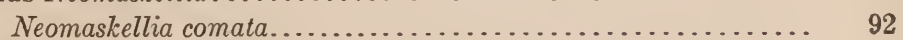

Literature referred to in the text............................... 93 


\section{ILLUSTRATIONS.}

PLATES.

Prate I. Figs. 1-12.-Wing renation in the Aleyrodidx

II. Figs. 1-7.-Anatomical details in the Aleyrodidæ-_-_-_-_--

III. Figs. 1-6.-Diagrams of aleyrodid structures_-_-_-_-_-_-_--

IV. Figs. 1-14.-Dialeurodicus cockerellii _._-___-_._-

V. Figs. 1-6.-Dialeurociicus silvestrii

VI. Figs. 1-8.-Dialcurodicus tessellatus

VII. Fig. 1.-Pupæe and waxy secretion of Dialeurodicus cockerellii on leaf. Fig. 2.-Tupæ ố Dialeurodicus tessellatus on leaf _-

VIII. Figs. 1-8.-Dialeurodicus pulcherrimus_-__-_-_-_-_-_-_--

IX. Figs. 1-14.-Leonardius lahillei

X. Figs. 1-12.-Aleurodicus anono

XI. Figs. 1-9.-Aleurodicus coccolobø

XII. Figs. 1-15.-Aleurodicus cocois

XIII. Figs. 1-7.-Aleurodicus destructor

XIV. Fig. 1.-Pupæe of Alcurodicus cocois on leaf, showing waxy secretion. Fig. 2.-Pupæ of Aleurodicus destructor on leaf, showing waxy secretion

XV. Figs. 1-13.-Aleurodicus dugesii

XVI. Figs. 1-11.-Aleurodicus guppyii

XVII. Fig. 1.-Punse of Aleurodicus dugesii on leaf, showing waxy secretion. Fig. 2.-Pupæ of Aleurodicus guppyii on leaf, showing waxy secretion

XVIII. Leaf infested with Aleurodicus guppyii, showing waxy secretion of pupse

XIX. Figs. 1-5.-Aleurodicus jamaicensis. Figs. 6-11.-Aleurodicus holmesii

XX. Figs. 1-11.-Aleurodicus neglectus _.

XXI. Fig. 1.-Aleurodicus holmesii: Pupæ on leaf, showing waxy secretion. Fig. 2.-Aleurodicus neglectus: Pupx on leaf, showing waxy secretion

XXII. Figs. 1-5.-Alcurodicus ornatus. Figs. 6-9.-Alcurodicus pulvinatus

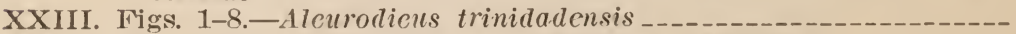

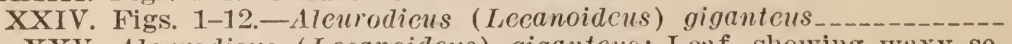
XXV. Aleurodicus (Lceanoidcus) gigantcus: Leaf, showing waxy se-
cretion of punæ and trails of secretion left by adults.---

XXVI. Figs. 1-5.-Alcurodicus (Iscanoideus) mirabilis. Figs. 6-11.-

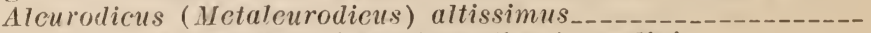

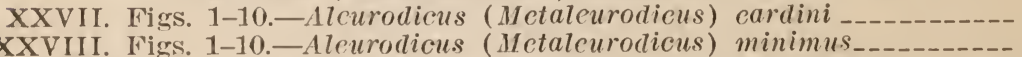

XXVIII. Figs. 1-10.-Aleurodicus (Mctalcurodicus) minimus_.
XXIX. Fig. 1.-Aleurodicus (Jecanoideus) mirabilis: Pupe on leaf, showing wax. Fig. 2.-Aleurodieus (Metaleurodieus) altissimus: Pupse on leaf, showing waxy secletion. Fig. 3.-Aleurodicus (Jeluleurodicus) minimus: Pupse on leaf, showing waxy secretioll_

XXX. Figs. 1-9. -l'araleyrodes persere

XXXI. Figs. 1-9.-P'uraleyrorles urichii

XXXII. Figs. 1-7.-17euroeliton aceris.

XXXIII. Firs. 1-10.-Aleurochiton forbesii

XXXIV. Figs. 1-S.-Neomaskellia comata

TEXT FIGURES.

Fio. 1. Genealogical diagram of the Aleyrodidx

2. Wings of Idamoselis pigmenlaria

3. Head of Inaleurodicus cockerellii

4. Leonardius lahillei; Pupa case, details

5. Lemardius lahillei, showing wax rods___.

6. Aleurodirus cocois: Insects in situ, pupa case, adult, abdomen_...-

7. Aleurodicus cocois: Adult mile and female, detalils_............-

8. Aleurodions cocois: Egrg, larve, and details_-_-_-_-

9. Alcurodirus cocois: Skin of full-grown larva_-_._-

10. Wings of Aleurodicus conspureatus

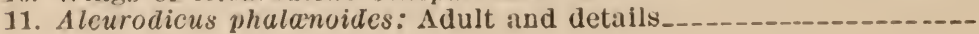




\section{CLASSIFICATION OF THE ALEYRODIDE-PART I.}

\section{INTRODUCTION.}

Few groups of insects have been more neglected by entomologists and collectors than the Aleyrodidæ. It is believed that comparatively few of all the species which undoubtedly exist have as yet found their way into collections. The family is widely distributed in the temperate and tropical regions of the world, and it will perhaps, when thoroughly worked, prove to be about as rich in species as the Coccidæ or Aphididæ.

Beginning with Maskell's paper, which appeared in 1895, there have followed a number of publications dealing with the Aleyrodidx, most of them systematic in character, but some dealing with the biology and habits of certain species of considerable economic importance. These papers have come from widely separated parts of the world, as New Zealand, the United States, India, Europe, Japan, etc., and indicate an increasing and widespread interest in these insects.

Until 1907 only two genera for the family were recognized, Aleyrodes and Aleurodicus. Since this date, however, three additional genera have been established, namely, Aleurochiton, Paraleyrodes, and Udamoselis, the discovery of which has thrown much light on the probable position of the Aleyrodidx in relation to other families of insects, and on the lines of descent of the several subgroups within the family itself.

The insect collections of the United States National Museum and of the Bureau of Entomology contain a large amount of material of this family received from correspondents from many parts of the country, and have been recently considerably augmented by the large series of specimens attained by Mr. R. S. Woglum, of the Bureau of Entomology, in connection with his search for natural enemies of the citrus white fly (Aleyrodes citri R. \& H.) in the Orient. The bureau also has, as stated in an earlier publication, through the kindness of the New Zealand Institute, the temporary custody of the Maskell collection of Aleyrodidx, including nearly all of his types. It has therefore seemed appropriate to undertake, at this time, a revision of the group as a whole, and to determine as 
accurately as possible a system of classification based upon the natural relationship of the various forms.

The present paper deals with certain features of the anatomy and external structure of the Aleyrodidx, and attempts to show the position of the family among homopterous insects. All species of the family at present known are treated, save those belonging to Aleyrodes, and this genus will be made the subject of a later publication.

It is hoped by the writers that this paper will facilitate the classication of these insects and further stimulate the interest already evidenced in them.

MORPHOLOGY OF THE ALEYRODIDE.

THE EGG.

The eggs of insects belonging to this family are elongate-oval in shape and are smooth on the surface or variously sculptured. This egg marking is often one of the simplest means of distinguishing between two closely allied species. The eggs are provided at or near their larger end with a stalk which, in such species as Aleurodicus holmesii, is extremely long. (Pl. XIX, fig. 6.) It serves as an attachment for the egg, but it also seems to direct the spermatozoa at the time of fertilization. At this time the stalk is filled with protoplasm and the mycropylar structure is plainly visible within the egg just at its entrance. After fertilization this protoplasm dries up and the stalk becomes a hollow tube. Cary, in his work on embryology, ${ }^{1 a}$ arrives at a similar conclusion, for he says:

The spermatozoan moves up through the protoplasm contained in the stalk of the egg, while the female pronucleus moves down and comes to lie at the entrance of the stalk. Immediately after the act of fertilization the protoplasmic contents of the stalk shrivel and dry up.

If, however, the primary function of this stalk is for the direction of the spermatozoa, it is strange that there should be such great variation in its length. It is certainly, however, not comparable to the protective stalk in eggs of such forms as Chrysopa, for it is not a waxy secretion but an extension of the chorion. The eggs of some psyllids, which are closely related to the aleyrodicls, possess stalks, but their exact function is unknown to $11 \mathrm{~s}$.

The arrangement of the eggs upon the leaf varies greatly with different species. The females of some insert the set $x$ into the tissues and, ising the rostrum as center and the body as radius, placo the eggs in regular circles. This habit was first noticed by Réaumur in 1736 , whose interesting observation we here quote. ${ }^{2}$

Pour y parvenir, \& pour avoir l'histoire de notre petit papillon, le 25. Juin je choisis une feuille sur laquelle il $\mathbf{y}$ en avoit un seul très-tranquille, \& que je 
jugeai y vouloir faire ses oeufs; je marquai l'endroit de la feuille où il étoit. Je trouvai, le lendemain 26. le papillon dans la même place; le 27 . il n'en avoit pas changé, mais tout auprès de lui il y avoit un petit espace à peu près circulaire, aisé à distinguer du reste de la feuille; il étoit poudré d'une poudre blanche, de celle qui blanchit toutes les parties de ce papillon; la elle éteignoit la vivacité du verd. Cet espace avoit environ une ligne de diamétre. Sur sa circonférence j'observai trois petits corps que je crus être des oeufs, \& qui en étoient réellement. Enfin le 28. le papillon s'étoit éloigné d'un demi pouce au plus de la place où je l'avois toûjours trouvé pendant les jours précédens. Il me fut plus aisé alors d'observer sans crainte de l'inquiéter, les petits corps qui étoient arrangés autour de la circonférence du petit espace qu’il avoit blanchi. Avec le secours d'une forte loupe, je reconnus que leur figure étoit assés semblable à celle des oeufs ordinaires, elle tenoit pourtant plus de la cylindrique. Ces oeufs sont oblongs, ce sont de petits cylindres dont les deux bouts sont amenés en pointes arrondies; leur plus grand diamêtre étoit à peu près dirigé vers le centre de l'espace circulaire.

In American literature Dr. Britton appears to have given the first account in 1902, though Davis mentions it in Insect Life, Volume VII, 1894. In describing the habits of a species on lettuce, Dr. Britton says: ${ }^{3}$

The fomale first thrust her beak into the leaf and depositing an egg swung about with her beak still inserted and serving as a pirot, continuing to deposit eggs in a circle of sbout one millimeter in diameter. One of these circles contained six, while another had nine eggs.

The same habit was described and figured by Dr. Back ${ }^{4}$ for Aleyrodes howardi Quaintance, and it has been described in connection with the description of species by the senior author and other writers. Some species, however, use no definite arrangement but scatter the eggs irregularly over the leaf almost exclusively upon the underside. The number of eggs deposited seems to be fairly large if the proper food conditions are found. Dr. Zehntner ${ }^{5}$ gives 150 to 200 eggs for Aleyrodes bergi Signoret, and Morrill and Back ${ }^{6}$ have secured 211 from a female of Aleyrodes citri Riley \& Howard.

Dr. Morrill was the first to note parthenogenesis in this family ${ }^{7}$ and we give therefore his original observations on the subject ${ }^{7 b}$.

Adult females have been isolater on plants previously free from Aleyrodes in any stage, for the purpose of determining the duration of adult life, the number of eggs laid by each female, whether or not parthenogenesis occurs, and, if so, its character. 'The females isolated for the purpose of these observations were seen to emerge from their pupa cases, and consequently there was no possibility of their having been feitilized. The plants upon which these females were kept were growing in small pots covered with lantern chimneys, which were closert at the top with cheesecloth. Four trials were made:

1. April 3, 1902, an unfertilized female began egg laying, and on April 17, three eggs were observed to have hatched.

2. April 17, 1902, an unfertilized female began egg laying, and on April 29 several eggs had hatched.

3. Dec. 8, 1902, a female emerged, was isolated on a tomato plant, and began egg laying Dec. 12 (females usually begin egg laying on the second or third 
day after emergence), and continued, averaging four per day for eleren days. Personal observations were here discontinued, but E. A. Back, an undergraduate student at the Entomological Laboratory, noted that the adult died Jan. 1. 1903. On Jan. 7 I found the plant dead, apparently from cold, and on examina. tion of the leaves I found that about three-fourths of the eggs had hatched, and that some of the larve were in the second instar at the time the plant died. Quite a number of eggs were found that had certainly been laid during my absence, but they were not counted.

4. March 17, 1903, a female emerged from its pupa case, and was isolated on tomato and chickweed growing in the same pot. Egg laying began March 18. Eggs were deposited on the stems and upper and lower surface of the leaves of both plants, making it impossible to count from day to day all the eggs that had been laid. On April 2, forty-nine eggs were counted, and on April 22 eighty more were known to have been added to this number. There were about eight days altogether when the female was in such a position on the plant that no attempt was made to count the eggs for fear of disturbing her. At a very low estimate, twenty-five eggs were laid during these days. The offspring of this female began to emerge as adults on April 22, and the original female was transferred to a chickweed plant growing in another pot. By an sccident I lost on the same day the positive identity of this insect, but I am quite sure that she produced the forty-nine eggs which I counted on April 29, after which observations on this insect were discontinued. So far as observed, all the eggs laid by this female hatched and the young reached maturity, the adults being males without exception.

To summarize these observations, unfertilized eggs hatch and the larvie develop into adults of the male sex. Two females were known to lay fortyfour and one hundred and twenty-nine eggs respectively, and in both cases many more were undoubtedly laid. These same insects lived in the adult condition for twenty-three and more than thirty-six days respectively.

I have tried several times to isolate a female which had certainly been impregnated, but was unsuccessful. It is not impossible to do this, however, and I suspect that when this is done the young produced from fertilized eggs will all devclop into females, giving us a condition similar to that which is generally believed to occur in the honey bees, and known as arrhenotoky.

In regard to the length of adult life, I might further add that in greenhouses where there are millions of live adults on the plants, it is difficult to find a single dead specimen on the benches, providing they have not been killed by artificial means. This is a further indication that natural deaths among adults are rare, and that the adult life of each individual may extend over many weeks.

Should it prove true that unfertilized eggs of this insect produce only males and fertilized eggs only females, then the number of adult males and females will be in direct proportion to the number of unfertilized and fertilized eggs. In Psyche (April, 1903) I gave an estimate of the proportion of the two sexes of Aleyrodes in nature, based on actual count of eighty-five specimens of adult Aleyrodes taken at random, representing four different species. 'The figures given were twenty males to sixty-five females. For the purpose of obtaining a more exact idea of the proportion of the sexes in the present series I counted one hundred adults taken at random, and found twenty-three males to serentyseven females.

Morrill and Back ${ }^{6}$ have further established the phenomenon, in Aleyrodes citri and it is not improbable that it will be found to occur in many species. 
The duration of the egg stage is about 12 days for the commoner forms. Temperature, however, seems to have a considerable influence upon the length of the stage, for in uniformly warm weather a much shorter time is necessary and under unfavorable circumstances the time may be greatly extended. The larva emerges from the egg by means of a longitudinal fissure in the anterior part of the egg and the time required for escaping from the shell varies considerably. In connection with her studies of Aleyrodidæ in California, Miss Bemis observed the hatching of numerous eggs and says: ${ }^{8}$

In the eggs under observation, there elapsed from forty-two minutes to three hours and eight minutes from the time that the shell began to open until the larva was free. The egg that took the greater time was upon dry material and was dari brown in color, the shell when empty keeping its upright position and shape, so that the slow hatching was probably due to the toughness of the chorion.

In our experience the drying of the material upon which the eggs are placed greatly retards or even prevents hatching.

THE HEAD OF THE ADULT.

The head is somewhat triangular in shape and is carried in such a way that its anterior surface is slanting ventro-caudad. The compound eyes are of the agglomerate type. They are usually constricted in the middle (reniform), or in some species are entirely divided by a tongue-shaped portion of the integument. It some= times happens also that the facets of these two sections are different in size. The ocelli are two in number and situated close to the anterior margin of the compound eyes. The position of these ocelli relative to the compound eyes varies in the different species.

The antennæ are placed below the eyes in shallow antennal sockets. They bear a striking resemblance to those of the Aphididæ. As a rule, they are composed of seven segments, of which the third is the longest. The first and second are always short and thick, while the others are elongate, subcylindrical, and covered with numerous imbrications. Circular fringed sensoria occur usually on segments III, V, and VII (see Aleurodicus giganteus, Pl. XXIV, fig. 10), and spike sensoria are sometimes also found. Fine hairs are scattered here and there or are found encircling the segments, and segment VII always terminates in a bristle-like armature. There is great variation in the length of the segments among different species in the genus Aleyrodes as at present understood. As a rule, segment VII is short, often the shortest of all. In species like graminicola, however, it is as long as all the other segments together and in longicornis very much longer. This variation may prove to be of importance in dividing the genus when the forms have been carefully studied. In Paraleyrodes segments III to VII have become united so as to form two. 
The vertex is rounded in most forms and often possesses a median longitudinal ridge or marking. In some forms, however, as in the genera Udamosetis and Dialeurodicus, it is produced into a large cone-shaped structure. This prominence between the insertions of the antennæ in both of these genera seems to point to their close relation.

The frons is rounded when viewed from the side and when viewed from the front it is somewhat $U$-shaped, the bottom of the $U$ forming the suture between it and the clypeus. Its upper edges extend backward. Below the clypeus is the labium, which is trapezium-shaped. The edges of this, as well as those of the clypeus, are slightly turned back so that as the structure lies on the labium there will be a better situation for the setæ. Below the labrum is a triangular sclerite, the epipharynx. All of these sclerites are somewhat united into an elongate triangular structure which, together with the setæ, remains attached to the head and is easily separable from the labium.

The labium is inserted in the base of the head on what is apparently a projection of the thorax. It is of considerable length and is composed of three segments. The relative length of these segments seems to vary in the different forms. Near its proximal end the labium is bent strongly caudad and appears to be grooved for its entire length. At the base this groove is wide, but more centrally it becomes narrower. The first (proximal) segment is much the longest and is narrow. It is in many forms, armed with a few scattered hairs. The second segment is thicker and shorter and the sutures separating it from the first are not well defined. This has no doubt given rise to Marlatt's statement that the labium is two-segmented. ${ }^{\circ}$ The third segment is short in Aleyrodes, while in Aleurodicus it is considerably longer. It is more heavily chitinized than the others and tapers distad. It is covered with numerous hairs and its tip is bilobed. Each of these lateral lobes is armed with three pegged-spiked tasto sensoria situated close together (Pl. II, fig. 4 ). It is noteworthy that very similar lobes and the same number of similar pegged sensoria occur on the labium of the Psyllidic. The labium in that family is also bent on its proximal part.

The maxillary and mandibular. sclerites are present below the frons, the lower extremity of the former becoming projections. The setre, four in number, constitute two pairs. Those of the inner or maxillary pair are closely pressed against ench other and sometimes for this reason appear as only one. 'The outer or mandibular setæe to a certain extent inclose the maxillary ones.

In his excellent paper on the hackberry Psylla, Stough has pointed out the very great similarity between the mouthparts in this family and those of the Psyllida. He says: ${ }^{10}$

The mouthparts, exclusive of the labium, are almost identical with, though larger than, those of the Aleurodidse which I have examined. The same 
sclerites are present, arranged similarly, though somewhat differently shaped. The labrum is much shorter and smaller proportionately than in this family, and the setæe seem to be relatively shorter. The end of the labium has the same lateral processes, but these are relatively smaller. 'The Aleurodid labium has a bend similar to that of Pachypsylla.

THE DIGESTIVE SYSTEM.

(P1. II, fig. 2.)

Our observations on the digestive system of the adult are as follows: Leaving the mouthparts the pharynx is met with as a narrow tube which passes gradually into the œsophagus. In the metathorax there is a distinct enlargement, the midintestine, and from this are given off two large saclike structures. From Cary's work ${ }^{1}$ we consider these gastric cæcæ, for he says, "After the dorsal wall of the enteron has closed a pair of diverticula are given off from near its anterior end." The midintestine is looped, as shown in the illustration, and joins the hind intestine in the anterior part of the body. This latter is narrow but is more dilated caudad of the rasiform orifice, where the anal opening occurs.

The nature of this orifice in the immature stages and the function of the lingula seem to have been imperfectly understood by some recent writers. The older writers, however, apparently had, in general, the correct idea of it. Westwood, for example, in his description of Aleyrodes vaporariorum, ${ }^{11}$ speaking of this structure, says, "With the anal apparatus placed at some distance from the hinder end of the body."

Peal, in 1903, discussed this structure at some length. We quote the following from his paper: ${ }^{12}$

Some time back, while I was examining an aleurodid which in its earlier stages is remarkably flat and transparent, I was fortunate enough to observe the lingula in motion. This organ was shot out beyond the vasiform orifice with extreme rapidity, it being protruded some four or five times a second.

When the lingula was shot out, the vasiform orifice moved in unison, the upper edge being bent inwards while the whole organ moved caudad. The internal opening of the lingula lies directly in the path of the rudimentary circulatory system, and when the organ is in motion it throws the circulatory fluid into a pulsating motion for some distance within the body cavity. I have been unable, so far, to detect the actual formation of the globules of honeydew, but as soon as the lingula comes to rest after a series of protusions a small globule may be seen just within the lower end of the lingula. This globule advances slowly, being apparently forced forward by the movement of the lingula, and after awhile reaches the tip of that organ I have never observed these globules within the lingula of an adult insect, but once on examining an adult male of Aleurodes simula, I perceived a globule of honeydew emerging from the lingula.

There is no doubt that the function of the organ is the secretion of huneydew and the operculum may be regarded as a protective covering to this organ. 
It would appear from this that Peal considered the rasiform orifice as a special secreting structure and honeydew to be connected in some way with the circulation. Miss Bemis seems to have a somewhat similar idea about the lingula, for she says, "In some species there are seen minute, blunt tubes on the apex of the lingula through which the fluid may be secreted."

In the introduction to a paper on Aleyrodidæ ${ }^{13}$ Tullgren discusses the vasiform orifice. His idea of its nature seems to be the correct one, but he does not go into detail, and we believe him wrong in calling the vasiform orifice the anal opening, for the anus proper seems to open within it.

In the forms examined by us the anus appears to open below the lingula (Pl. II, fig. 5) which functions as the supraanal plate. We are unable to find a definite opening at the tip of the lingula. In any case, whether the anus is always at the base or sometimes at the apex, as in the Psyllidæ, this in no way alters the standing of the lingula, which would in either case be the supraanal plate. The operculum is a little more difficult to place. It would not appear strange if it were believed to correspond to the rudimentary last abdominal segment in the Aphididæ, as suggested by Tullgren, for its position in regard to the anal plate is rery similar. It does not, however, often appear as a distinct segment, but looks like the rolled-back edge of the lingula.

The substance known as honeydew is, as implied above; merely the excrement of the insects. It is deposited in large quantities by the larvx, pupæ, and adults and forms a medium for the growth of several fungi. The early pupæ excrete much more than the late pupæ, while the larræ, in the earlier instars, excrete the most of all, the substance being ejected once or twice for every minute, although not always at regular intervals. The salivary glands are two rounded bodies situated one on either side of the head and united by small ducts.

The exact nature of the wound of the puncturing setæ of Aleyrodidæ we have not ascertained, but in all probability it is similar to that made by the $A$ phididx and the Coccidx, where the setx pass around the outer cells and finally puncture the soft bast cells from which the proteid content is taken. These proteid substances form the bulk of the insects' food, while much of the sugars taken in at the same time are passed out as honeydew.

\section{THE WINGS.}

The wings are first noticed in the late embryo as imaginal disks produced as ingrowths of the hypodermis. These, losing their connection with the outer layer, soon take on the appearance of closed 

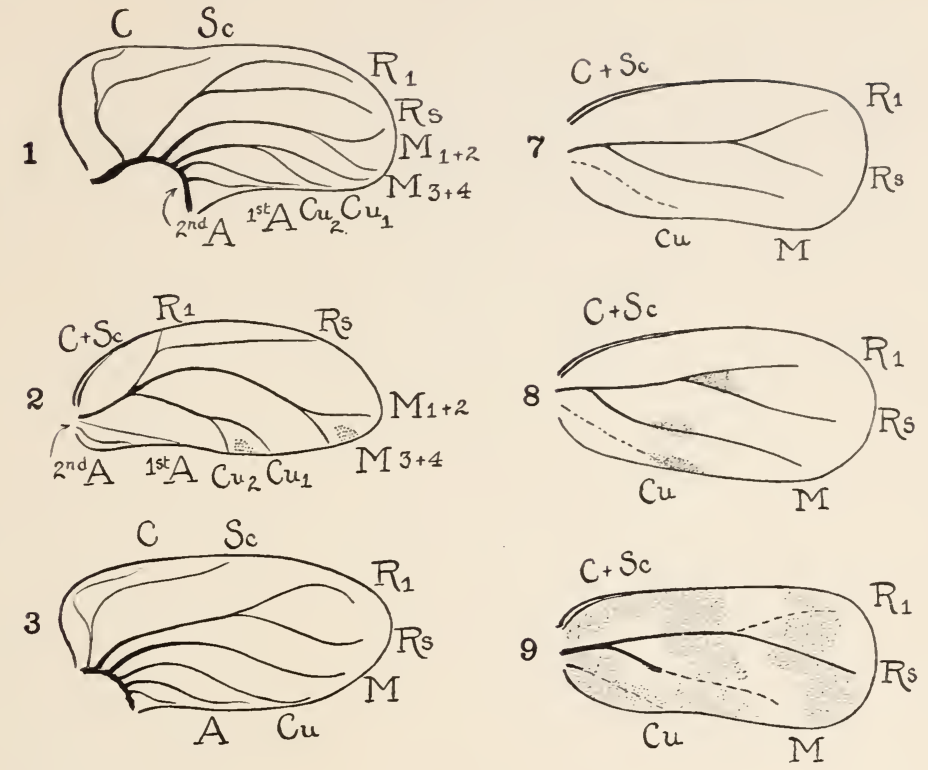

4

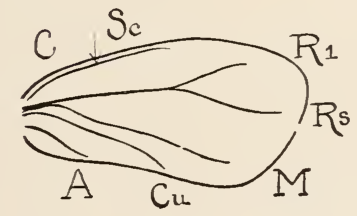

5
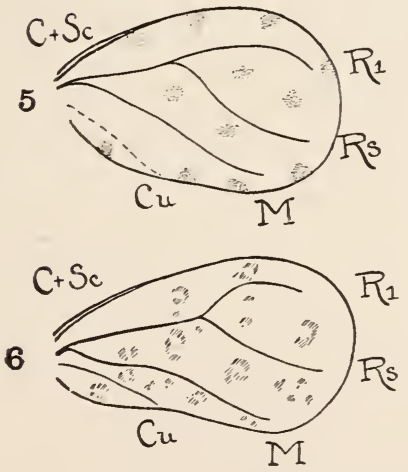
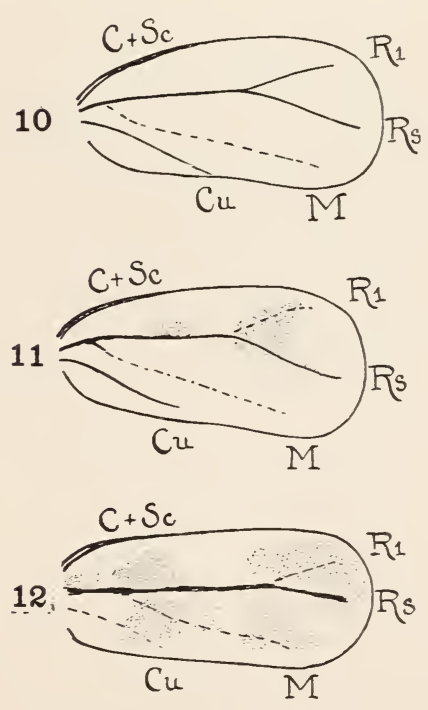

Wing VENATION IN THE ALEyRodide.

Fig. 1.-Theoretical origin of the veins of the psyllid genus Trioza, showing tracheæ. Fig. 2.-Forewing of Trioza sp. Fig. 3.-Theoretical origin of the reins of Alerrodidæ, showing tracheæ. Fig, 4-Forewing of $U$ damoselis pigmentaria. Fig. 5-Forewing of Dialeurodicus cockerelli. Fig. 6.-Forewing of Aleurodicus conspurcatus. Fig. 7.-Forewing of Aleurodicus destructor. Fig. 8.-Forewing of Aleurodicus (M ctaleurodicus) minimus. Fig.9.-Forewing of Paraleyrodes persex. Fig.10.-Forewing of Aleurochiton aceris. Fig. 11.-Forewing of Aleyrodes sp. Fig. 12.-Forewing of Teomaskellia comata. (Original.) 


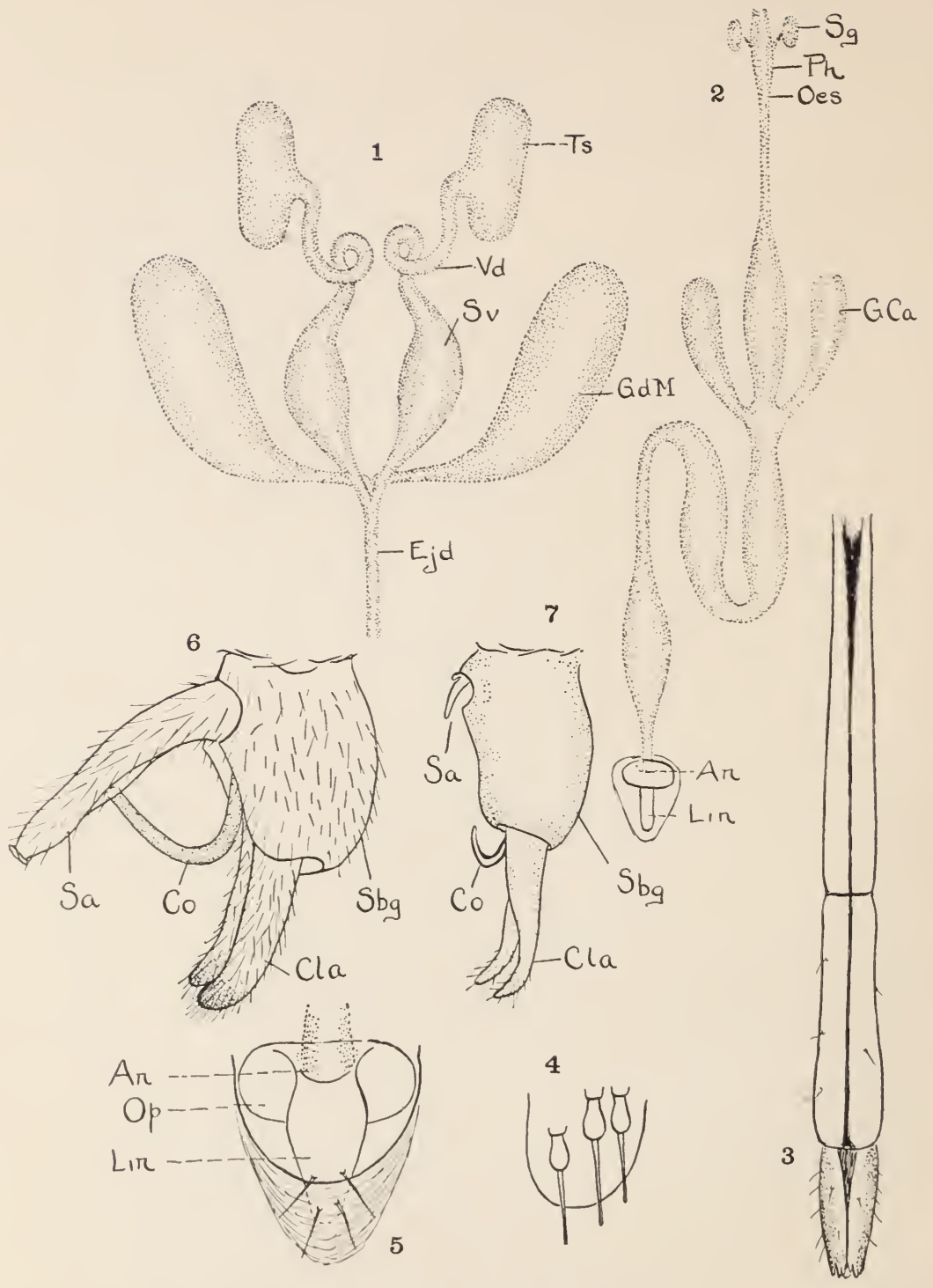

Anatomical Details in the aleyrodide.

Fig. 1.-Male reproductivo organs: $T s$, testis; $V d$, vas deferens; $S v$, seminal vesicle; $G d M$, glandula mucosa; $E j d$, cjact latory (luct. Fig. 2.-D)igestive tract: $S g$, salivary glands; $P h$, pharynx; Ocs, oesophagus; $G C^{\prime} a$, gastric exea; $A n$, anus; 1 in, lingula. Fig. 3.-Labium of Aleyrodes sp. Fig. 4.-Taste sensoria on lobe of apex of labium. Fig. 5- Vasiform orifice, ventral view: A $n$, anus; ()$_{\mu}$, opereulum; $L$ in, lingula. Fig. 6.-Diagram of genital segment of male I'sylla: Sa, supraanal plate; (o), copulatory organ: Cla, claspers; Shg, subgenital plate. Fig. 7.-1)iagram of genital segment of male A leurodicus: $S a$, supraanal plate: $C o$, copulatory organt; C'la, claspers; Shg, subgenital plate. (Original.) 
sacs. During the pupal stage the wing disks come to lie outside the body, the pads are developed, and in the late pupæ the wings themselves are folded up within the case. They are four in number, membranous, and are composed of two thin, superimposed lamellæ. In the preparation of mounts with potassium hydroxid, these plates often become separated and the wings become opaque and sac-like in form. The border of the wings all around in most species is covered with a series of knob-like or bead-like projections on which occur a number of fine hairs. These hairs vary in number. In some species there is a large central hair on each knob with two or three small ones on each side. In others the hairs are subequal in length and very minute. In Aleurodicus the proximal half of the costal margin cf the forewing is armed with a number of large spine-like hairs situated on small receptacles. These hairs are placed a short distance in from the costal margin and are arranged along what apparently represents the subcosta. The hairs are directed distad. The hind wing of all species is armed on the proximal portion of its costal margin with a row of strong curved hairs which aid in keeping the wings together during flight. The number of these hairs varies, but from seven to nine hairs are most usually met with. In the Psyllidæ a similar row of hairs is situated in the same region, but there is usually a larger number. In the Aphididæ, on the other hand, this structure is usually replaced by three hook-like hairs situated, not at the base, but on the distal half of the wing.

To illustrate the venation in this family we will use as a basis of comparison the wing of a species of the psyllid genus Trioza (Pl. I, fig. 2), following the nomenclature as worked out for that genus by Miss Patch. ${ }^{14}$ Comparing with this the wings of Udamoselis pigmentaria Enderlein (Pl. I, fig. 4), we see that the veins of the costal region are separate, although very close. These undoubtedly represent the costa and subcosta. We find that radius ${ }_{1}$ and the radial sector are represented in exactly the same manner as in Trioza. The media and cubitus have a position very similar to these veins in the psyllid, but are not branched, while the first anal, the only one present, is in identically the same position in both forms. For species possessing these veins the subfamily Udamoselinæ has been erected and at present includes only the one known form.

In the genus Aleurodicus (Pl. I, fig. 7) the costal vein is made up of costa and subcosta. These are as a rule united, but in some species they are separated at the base and can be distinctly traced. The veins radius ${ }_{1}$, radial sector, and media, are represented as they are in Udamoselis. The cubitus and anal, however, have disappeared. This disappearance of the cubitus and the retention of the media form one of the main lines of descent in the family and for the forms showing it the subfamily Aleurodicinæ may be erected. It is 
worthy of mention that in minimus Quaintance (Pl. I, fig. 8) the cubitus is represented by a faint line or fold and in conspurcatus (Pl. I, fig. 6) it is retained, this latter species possibly being a connecting form.

In the genus Aleurochiton (Pl. I, fig. 10) this state of affairs does not hold, but an opposite line of descent is indicated and the forms showing this may be grouped in the subfamily Aleyrodinæ. Here the costa and subcosta are united to form one vein. Radius ${ }_{1}$ and the radial sector are present as in Aleurodicus. The media, however, is absent or only faintly indicated in freshly emerged specimens. The cubitus, on the contrary, is well retained and forms a distinct vein. It may be noticed here that the pupa of Aleurochiton has not the large compound pores of Aleurodicus.

In examining a wing of the genus Aleyrodes (Pl. I, fig. 11) we see that the costa and subcosta are again united, the radial sector is retained, but the radius ${ }_{1}$ has disappeared. In some material a faint rudiment of this vein is noticeable. The media, as in Aleurochiton, has entirely disappeared and is made out plainly only in the fresh wing. In some species, however, the rudiment of this vein is noticeable and has been observed as early as the time of Signoret, for he says, speaking of fragaria "Dans cette espece, entre la nervure mediane et la nervure oblique de la base, j'en ai observe le commencement d'une seconde." The cubitus is here retained and forms the second vein of the wing. It is evident, then, that Aleyrodes is an offshoot from Aleurochiton by the reduction of radius ${ }_{1}$. 'This is borne out also by the pupa, which has no large compound pores. The careful work of Miss Patch ${ }^{14}$ on tracheation in this genus corresponds exactly with our observations. She figures and describes the venation in Aleyrodes sp. and shows clearly that the second vein of the wing is the cubitus. Her words are, "The second vein of the wing of Aleurodes is cubitus, as will be seen by comparing figures 44 and 45 , where the second vein is shown to follow the courses of the cubital trachea." In this family Miss Patch, however, treated only the genus Aleyrodes.

The venation in the genus Paraleyrodes (Pl. I, fig. 9) appears at first glance like that of Aleyrodes, but more careful study shows it to be very different. The costa and subcosta are here united and the radial sector is retained. The second vein of the wing, however, is not the cubitus, but the remnant of the media, and can be found as a branch of the main vein. Moreover, in some specimens of persece the cubitus can be seen faintly indicated in its usual position. This venation shows, then, that Paraleyrodes is not closely related to Aleyrodes, but is a branch from Aleurodicus by the reduction of the media and radius ${ }_{1}$. This view is also borne out by the structure of the pupa, which has the compound pores of Aleurodicus, and of the 
foot, which has the paronychium represented by a spine as in that genus.

In Neomaskellia comata Maskell (Pl. I, fig. 12, and Pl. XXXIV) we find the greatest reduction in the family. Here the costa and subcosta are united, and in the body of the wing only one vein, the radial sector, remains. (It should be noted here that Maskell's figure of this species is wrong. Our drawings were made from his type and the small vein he figures does not exist.) It is evident, then. from the venation that comata forms the type of a new genus. This is also indicated by the hairy psyllid-like claspers.

The species Dialeurodicus cockerellii (Quaintance) (P1. I, fig. 5; Pl. IV, fig. 3) shows the same wing venation as Aleurodicus, but the type of vertex and the absence of compound pores immediately place it elsewhere.

In this connection should be mentioned an article by Sophie Rostrup ${ }^{16}$ which, since it is apparently followed by Dr. Max Wolff, deserves some notice. As the communication is short we quote it entire:

Aleurodider er en lille med Skjoldlus og Bladlopper naerbeslaegtet Familie af smaa, møllignende Dyr. Ved et Bes $\emptyset \mathrm{g}$ af mig i Ringsted i August 1905 indsamlede Landbrugskandidat, Gaardejer Pallesen, Kaerehave, Blade af Guler $\varnothing$ dder, angrebne af Krusesyge, paa hvis Underside der fandtes en Del smaa Dyr, om hvilke Hr. Pallesen meddelte mig, at han ofte havde set den paa saadanne Blade. Ved naermere Unders $\phi$ gelse riste de sig at høre til orennievnte Familie. Imidlertid fandtes der ingen udviklede Insekter, kim Larver og Nymfer; saa vidt det kan afg $\varnothing$ res efter dette Udviklingsstadium, synes de at høre til Slaegten Aleurodicus, der hidtil ikke har vaeret kendt fra Evropa. Larver og Nymfer er forsynede med et fint Voksovertraek og sidder uberaegreligt med deres lange, tynde Snabel indboret i Planteraeret og suger af dette. Spørgsmaalet, om disse Dyrs Sugning staar i Forbindelse med Krusesygen og i saa Tilfaelde, hvilken Del de har i denne, kan paa naerraerende Tidspunki ikke afgøres. Drofessor Kølpin Ravn mener oftere at have bemaerket disse Dyr paa Gulerod.

It is evident by examining the figures that the specimens referred to do not represent a species of Aleurodicus, but belong to the Psyllide and are very likely near Trioza. The pulvillus of the foot, the general form, the marginal wax fringe, the wing venation, the lack of vasiform orifice, in fact, all the characters noticeable in these figures are those of the Psyllidæ and not of the Aleyrodidæ. Any ideas, therefore, based on the venation in these figures must be discarded.

\section{MALE GENITAL ORGANS.}

In male Aleyrodidæ the abdomen ends in a heavily chitinized collar on the dorsal surface of which is found the vasiform orifice and from the extremity of which protrude the claspers and the copulatory organ. It does not seem impossible that this last segment represents $61201^{\circ}-13-2$ 
the subgenital plate and has been produced by the fusion of the upper margins of that plate, while the lingula, as explained elsewhere, represents the supraanal plate. This would seem suggested from the state of affairs found in the Psyllidx, for in comparing Psylla sp. (Pl. II, fig. 6) and Aleurodicus sp. (Pl. II, fig. 7) it will be seen that the genital segments are very similar. If in the psyllid the upper margins of the subgenital plate were united above the claspers and the supraanal plate reduced, they would be almost identical. In any case, howerer, the close relation of the two families seems indicated by this structure. The shape and armature of the claspers vary considerably in different species, but as a rule these organs are curved at the distal end and armed with a number of spines. Those of comata are very hairy and psyllidlike. Each clasper generally has on the outer margin of its distal part a rounded shoulder and its distal end is formed into two processes for the attachment of the muscles. The copulating organ is found between the claspers. It is usually single, but in Paraleyrodes persece it appears bifurcate. It is an elongate, subcylindric rod, tapering on its distal part and swollen at the base. In some forms it appears grooved on its upper surface for the reception of the penis, but in others we are not able to make this out, but the two secm fused into one structure. The penis is carried recurved toward the vasiform orifice in a manner very similar to that found in the Psyllidx. The ejaculatory duct extends cephalad some distance from the base of the penis, where it has its origin in the union of the two vasa deferentia.

The testes (Pl. II, fig. 1) are globose or elongate bodies situated one on each side of the median line of the abdomen. The vas deferens, in leaving the testis, is coiled upon itself and then swollen considerably to form the seminal vesicle. Again contracting, it is united with its fellow and forms the ejaculatory duct At this place of union are found the openings of the ducts leading from the two large sac-shaped structures, in all probability the glandulæ mucosæ. The external genital organs of the male are definitely formed in the pupal stage and fairly early in this stage the claspers can be seen fully shaped. They are developed, according to Cary, from the two pairs of posterior abdominal imaginal disks. The reproductive organs can be seen in all the larval stages as a pair of gland-like masses, one on either side of the abdomen.

FEMALE GENITAL ORGANS.

The supragenital segment in female Aleyrodidx shows some variation in form. In Aleyrodes it is broad and crescent-shaped and is armed with regularly placed hairs. It is often difierently pigmented from the surrounding portions of the body and is situated some dis- 

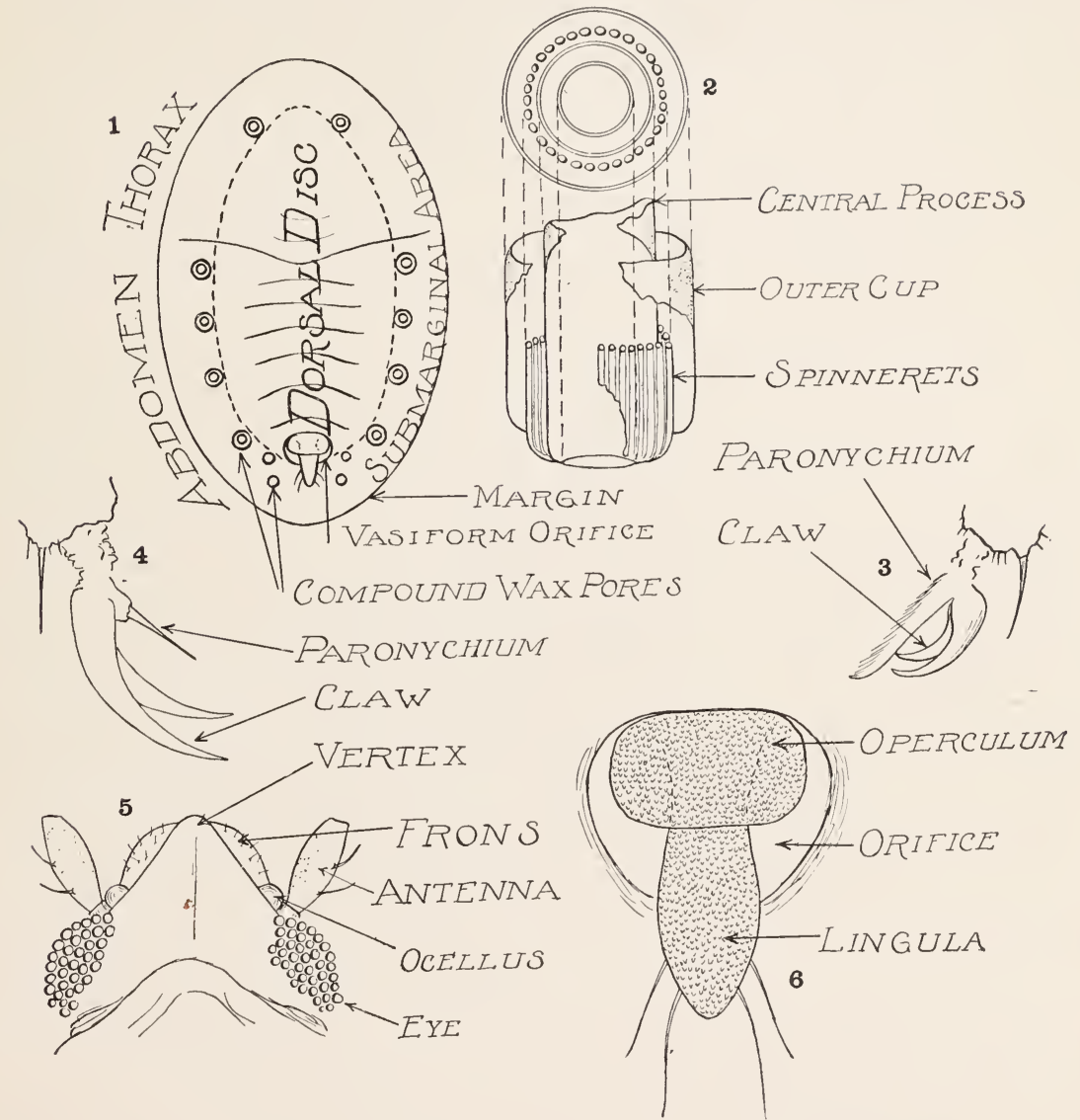

\section{Diagrams of ALEYRODID STRUCTURES.}

Fig. 1.-Pupa case. Fig. 2.-Compound wax pore. Fig. 3.-Foot of subfamily Aleyrodinæ. Fig. 4.Foot of subfamily $\Lambda$ leurodicinæ. Fig. 5.-Head. Fig. 6.-Vasiform orifice. (Origincl.) 

tance cephalad from the tip of the ovipositor. In Dialcurodicus it appears to be very similar in shape, but in Aleurodicus it is narrower and more elongate, while in Paraleyrodes it is rounded. What apparently corresponds to the subgenital plate here is a large structure covering the caudal ventral portion and extending some distance dorsad on each side. The structure of the ovipositor is considerably like that found in the Psyllidæ, while it differs quite markedly from the structure present in the $\Lambda$ phididx. It is composed of six parts, the outer covering of which usually bears a definite number of hairs. These parts are grouped into pairs. The inner and upper pair of these is usually distinct for some distance, at least, and the parts are easily separable. The outer pairs, however, have grown together almost entirely and appear as one pair. Occasionally, though, they can be seen split at their tips, as is the middle pair, and they are sometimes sculptured or serrate. Extending throughout the ovipositor there are a number of chitinized rods. These appear to be composed of parts jointed together and working one against another. There are present toward the tip flattened structures which apparently correspond to the "sting palpi" of the Psyllidx. The ovaries are two in number and very large. They are composed of five-chambered ovarian tubes and in some cases almost entirely fill the abdomen. The receptaculum seminatis is ventral and the oviduct, coiling upon itself considerably, opens between the valves of the ovipositor.

\section{LEGS OF THE ADULT.}

The rudiments of the legs appear very early in the embryonic state, at about the same time as those of the mouthparts. A study of the legs of the adults is interesting, as it tends to throw some light on the position of the family. The three pairs are considerably alike, varying only in the relative lengths of the different segments. The femora and tibix are elongate and armed with spines and hairs. The tibire especially possess sereral longitudinal rows composed of prominent spines placed close together. On the distal third these become fewer in number, excepting for a comblike structure, which is found in at least several species. The distal end of the tibir is surrounded by a number of short spines which, though much weaker, suggest the jumping spines of the Psyllidæ. The tarsus is composed of two segments almost equal in length, and in this regard it is much closer to the Psyllidæ than to the Aphididæ, in which one segment is very much reduced, or to the Coccidæ and some Aphididx, in which it is altogether lost. Attaching the claws and paronychium to the tarsus proper are a number of irregular pieces difficult to make out and which may be part of the tarsus. The foot itself seems much nearer to that of the Psyllidæ than to that of the Aphididæ, for the 
Psyllidæ have a prominent bilobed pulvillus, while the Aphididæ have practically none. In some forms in the Aleyrodinæ the paronychium is very prominent, and in all forms it is represented either by a pad or a spinelike structure. The paronychium in the Aleyrodidæ, however, is never bilobed as in the Psyllidæ, though in some species there is a slight indication of this.

\section{WAX PORES OF PUI'A CASE.}

The secretion of wax is very common in many of the Homoptera and is particularly noticeable in the families related to the Aleyrodidx, namely, Psyllidx, Aphididæ, and Coccidx. In the Psyllidx besides the anal wax glands there are in the larra of many species abdominal and marginal wax glands, the marginal ones of which secrete long, fine, hollow, brittle, waxen hairs, which form a fringe about the insect. In the Aphididæ the glands are usually grouped. In Schizoneura and some species of Pemphigus the secreting cells are arranged in rings, while in Chermes, Mindarius, etc., they are agglomerate in nature, and in some forms these agglomerate pores are surrounded by a chitinized ring.

In the larvæ of the Aleyrodidx we have three types of pores: namely, simple, agglomerate, and compound. In the Aleyrodinæ the dorsal pores present are all simple, though many of them may be larger than other's and arranged in definite rows, producing a fringe comparable to that in the larræ of the Psyllidæ. It is in the Aleurodicinæ that the derelopment of special wax secreting structures is found and this development seems to throw some light on the relation of the forms. In Dialenrodicus the dorsal pores are simple and usually scattered, though in silvestrii the greater number of them are collected into a subdorsal band. In the species lahillei these simple pores have taken on a definite and restricted arrangement, forming agglomerate pores as in some Aphididx. In the center of some of these, however, is found a large, chitinous process which points to these as near the forerumners of the true compound pores in Aleurociicus. This fact, together with the shape of the lingula, wing, etc., seems to indicate that lakillei is the type of a new genus older than Aleurodicus, but not so old as Dialeurodicus. In Aleurorlicus the compound pores have a constant structure in all the species, indicated in Plate III, figure 2. The chitinous ring surrounding the agglomerate pores in some other forms is here a definite elevated cup-like structure. Within this cup the spinnerets are arranged in a ring similar to the ring in Schizoncura, but, unlike these cells, are produced into more or less elevated rods or tubes. Within this ring of spinneret rods is a chitinous process, apparently hollow, which may be very long, as in holmesii, or as short as the outer cup. In P'araleyrodes, while the pore is of the same compound type, it is different in 
appearance, for here the ring of spinnerets is not extended into rodshaped structures, but is seen only at the base. The outer cup is very shallow and the central chitinous process is split into a number of sections. It would appear that in Paralcyrodes the spinnerets and outer cup have become shortened at the same time with the media and radius ${ }_{1}$. The compound pores of the forms belonging to the subgenus Metaleurodicus are of an intermediate nature. The spinnerets are reduced in minima and cardini in a manner comparable to those of Paraleyrodes, but the central process is entire. In altissimus besides the reduction of the spinnerets, the central process is split into three divisions. In these forms, howerer, the lingula is short and generally included, unlike the typical forms of Aleurodicus or Paraleyrodes. Unfortunately the adult of altissimus has never been secured as, from the pupa, it appears to be a very interesting form; but whether it is nearer Paraleyrodes or Aleurodicus can be decided only by an examination of all the stages.

RESPIRATORY SYSTEM.

The respiratory system in Aleyrodidx seems to be more fully developed in the larval stages than in the adults. In some forms, as in those belonging to the citri group, there are in the immature stages special breathing folds developed which are often indicated on the dorsal surface by sculpturing and the outer extremity of each is guarded by stellate or other serrations on the margin of the case. The folds are three in number, there being a latero-thoracic pair and a caudal fold, this latter extending from the vasiform orifice caudad to the margin and forming a $Y$-shaped structure which extends to the posterior thoracic pair of spiracles. In some species, even when the thoracic folds are not noticeable, the caudal fold will be long and deep. The courses of the various tracher have been worked out by Woodworth for Aleyrodes citri and the observations of more recent writers on the subject, as well as those made by ourselves, only substantiate his findings.

In the adult the system follows the same plan as in the larva. There are the same number (four pairs) of spiracles present, one pair of which is abdominal and situated near the vasiform orifice. The trunks and girdle are, however, much more reduced in the mature insect.

\section{METAMORPHOSIS.}

The metamorphosis in this family has always been an interesting and problematical subject of study. During the later larval stages the antennæ, mouthparts, and legs become, to a certain extent, atrophied. In the pupal stage, however, they appear to be, in some cases at least, functional. In Dialeurodicus cockerellii, for example, there 
is not oly a prominent labium in this stage. but it is arned with taste sensoria. The function of the nervous srstem is not suspended during the entire life of alerrodids. but as a similar state of afiairs is fownd in such forms as the Mnscider. this indicates little. The digeative srstem, with a few alterations. seems to pass orer from the larra to the autu. The reproiuctire organs derelop in the pupal stage and sume, though not extensire, histolrsis oceurs. The adults without question feet. for they may be sten in the act and the honerdew excreted is a furher evidence of this. It would appear that during the first part of the last (pupal) instar. the insect lives a life similar to that led in the eariler stages. During the last part. howerer. actirity seems to cease for a short time. While transformation takes place within the larval slin. This change appears to be gradual in some respects and the metamorphosis in the Aleprodida may be considered as of an intermediate type.

The alult emerges through a T-shaped opening on the dorsum of the pupa case. I thort time before this opening is noticed, the insect may be seen fully formed within the case, and as it cromds in frum the elges the rupture takes place. The thorax is first to emerge, followel by the head. The antenna and legs are nest worked free and the insect assumes an upright or recurred position similar to that adopted by many other invects in this process. Finalls the abdomen is morkel free and the insect mores awar. The time normally occupied in this proces is only a few minutes. There the pupa cases are hard. howeter. a much longer time is required and it is not uncommon to see insects struggle for hours and finally die without being able to free themselres. After the adults hare left the case it requires -ome minutes for the wings to expand and the colors and $\pi a x y$ secretion to derelop. Morrill and Backs have giren careful observations on the act of emercence of Aleyrodes citri, which in the main agree with our- here recorded. They also eive the effects of temperature and humidity on the emergence of that species, stating " that temperature and not humidity is the more important factor gorerning emergence in Florida." On the other hand, Mr. R. S. Moglum. of the Bureau of Entomologt, who has made extensive obserrations on this species in India and the Orient, is of the opinion that humidity is the grorerning factor. He states that the emergence of the flies, at least in any number. always follows a rise in humidity, while the optimum teriperature under these conditions, together with a low hamidity. seems to check emergence.

\section{CLASSIEICATION.}

Until recently only two geriera. Aleyrodes and Aleurodicus, were recogaized for the family Alerrodidx. Within the past three or four year however, there have been established the additional genera 
Aleurochiton, Paraleyrodes, and Udamoselis. These genera include species showing a considerable variation in important characters and, with other material available. furnish a basis for the consideration of their relationships and probable lines of descent. Information on these questions is essential for a correct understanding of the position of the family among the Homoptera and for the assignment within the family of the rarious species into natural groups.

Until the recent paper by Dr. Enderlein ${ }^{18}$ no attempt has been made to divide the family into subfamilies, and to date there has been no attempt to show the natural relations of the genera. Enderlein erected the subfamily Udamoselinæ, in which he included also Aleurodicus, and the subfamily Alerrodinæ, in which were placed all other known forms.

In the following classification we restrict Udamoseling to the forms in which both media and cubitus are present. Our reasons for this. our ideas on the relation of the genera and the srstematic position of the family. and a discussion of the subfamilies follow. It appears to us, from a careful study of the different forms. that the Aleyrodidx are not intermediate in position between the Aphididæ and Coccidx but that they form an offshoot from the psrllid stem. This is indicated by the wing renation and by the structure of the mouthparts, legs, and genitalia.

The renation of the wings of this family has been compared with that of a psyllid wing under a separate heading (p.9) and it is clear that the ancestor of the Aleyrodidx had a wing form and renation rery similar to the psyllid type. Under another heading (pp. 12-13) the genitalia of this family and those of the Psyllidid have been compared. The resemblance here is rery striking. In the males only a slight modification of the structure found in the Psyllidæ is necessary to produce the type found in Aleurodicus, while the Aphidida hare a widely different structure. In the females. too, the same condition is found to be true. The oripositors in the two families are remarkably alike. while in the Aphidida this structure shows almost no resemblance. In this second character, then, the two families are thus seen to be closely related.

The mouthparts show the most remarkable resemblance. In fact, with a rariation in form of some parts and a difference in size. the two are identical. Even the same number of similarly formed taste sensoria are present on the labium.

In the legs, again, this similarity is to be noticed. In the presence of the pulvillus and the segmentation of the tarsus, the Alerrodidx are much closer to the Psyllidix than to the Aphididx.

The family itself shows two distinct lines of descent. In the one the media is retained, the cubitus is lost, and large compound wax pores are often dereloped in the pupæ. In the other the media is 
lost, the cubitus is retained, and no pupal compound wax pores are present. This divides the family at once into two distinct subfamilies to which the names Aleurodicinæ and Aleyrodinæ may be applied. Outside of these two subfamilies we have the form Udamoselis pigmentaria, which is much more generalized than any other. It retains both media and cubitus and we place it, at present, alone in the Udamoselinæ. Te have included in the Aleyrodinæ three genera, Aleurochiton, Aleyrodes, and Neomaskellia. The first is the most primitive, and from it Aleyrodes has arisen by the reduction of radius ${ }_{1}$. Neomaskellia, however, seems to have separated earlier than Alcyrodes, for it retains very hairy psyllid-like claspers and the wing venation is more reduced. The genus Aleyrodes at present includes many diversified forms and a careful study of these will no doubt necessitate the breaking up of the genus.

In the subfamily Aleurodicinæ the most primitive form seems to be Dialeurodicus cockerellii. This species, while it has developed the wing venation of Aleurodicus, still retains head characters which ally it to Udamoselis. The pupa, too, has no compound wax pores as in the genus Aleurodicus. With this species as type, Cockerell erected Dialeurodicus and placed it as a subgenus of Aleurodicus. It is evident, however, that this does not represent its true position, but that it is considerably older than Aleurodicus. We therefore make it the type of a genus rather than a subgenus. The species described as Aleurodicus lahillei, as discussed under wax pores (p. 14), shows characters intermediate between Dialeurodicus and Aleurodicus. These characters are so marked and evidently intermediate that we make it the type of a new genus, Leonardius, allied to Dialeurodicus in wing form, vertex, and vasiform orifice, and showing a development toward Aleurodicus in wax-secreting structures. The genus Aleurodicus is separated at once by the wing venation, the dofinite wax-pore structures, and the long exserted lingula. There are, however, forms of this type in general structure which have an included lingula and wax pores tending toward those of Paraleyrodes. For these forms we erect a subgenus, Metaleurodicus. This subgenus does not seem to be directly on the line toward Paraleyrodes. It is, as far as wax pores are concerned, but the lingula seems to place the group by itself.

The genus Paraleyrodes is plainly derived from near Aleurodicus by the reduction of the radius and part of the media, and by the shortening of the spinnerets and the cup of the wax pore. At the same time some of the segments of the antenna have united. It is the most specialized genus of the Aleurodicinæ as Neomasticllia is the most specialized in the Aleyrodinx. The position of the family and the relations of the genera, as we understand them, are shown in figure 1. 


\section{FAMILY ALEYRODIDE W EsTwood.}

Small or minute insects; oviparous, eggs stalked; metamorphosis intermediate; larval stages (except first) quiescent upon leaves of plants; most species surrounded or covered with a waxy secretion.

Mature sexes with four wings which are transparent, white, clouded or mottled with spots or bands. Antennæ in most grenera of seven segments; compound eyes single or divided (reniform); ocelli two. Tarsi of two segments, terminating in two claws and a median process or paronychium; mouthparts suctorial, labium long, 3-segmented,

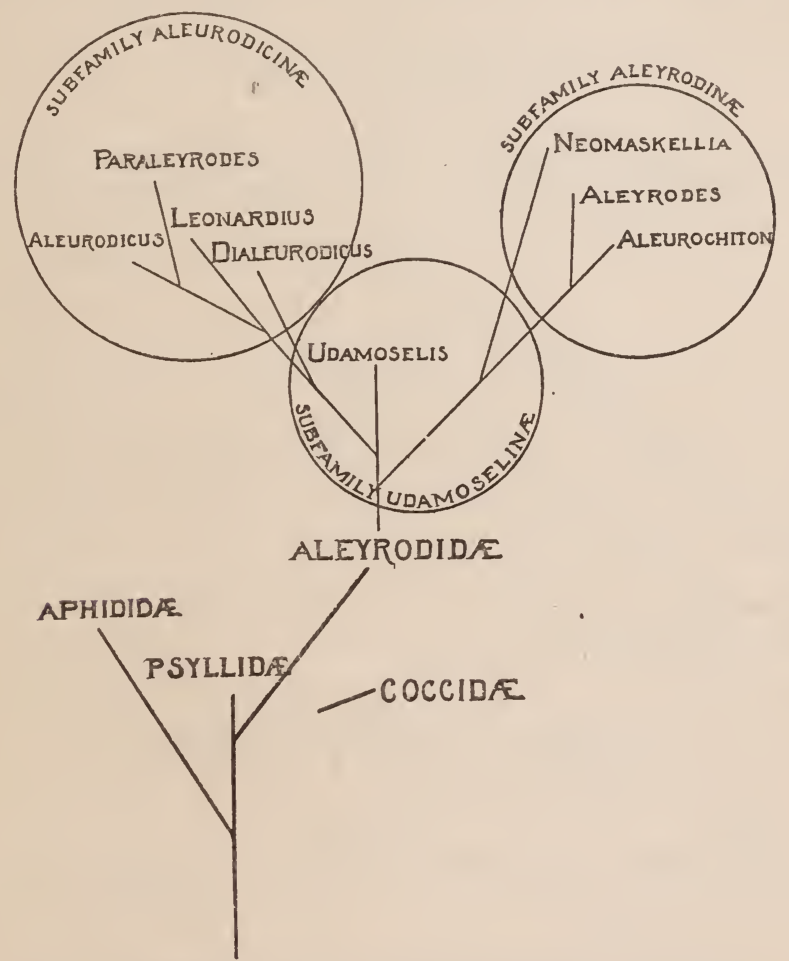

Fig. 1.-Genealogical diagram of the Aleyrodidæ. (Original.)

setæ four; male genitalia a pair of prominent claspers; female genitalia an acute ovipositor. Anus opening dorsally at the so-called "vasiform orifice."

\section{Subfamilies of THe Aleyrodid}

A. Forewing with radius $\mathrm{s}_{1}$, radial sector, media, cubitus, and anal reins present. Vertex produced I. Udamoselince.

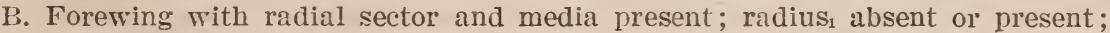
paronychium spine-like.

II. Aleurodicinœ n. subfam.

C. Forewing with radial sector and cubitus present; radius ${ }_{1}$ absent or present; paronychium blade-like. 


\section{Subfamily Udamoseliñ Enderlein.}

The members of this subfamily have the forewing with the costa and subcosta distinct. The radius 1 , radial sector, media, cubitus, and anal vein are present.

One genus only, Udamosetis, is known.

\section{Genus UDAMOSELIS Enderlein.}

Udamosclis Enderlein, Zool. Anz., Bd. 34, N. 7/8, p. 231 (1909).

This genus was erected by Enderlein, who characterized it as follows :

\section{UDAMOSELIS nor. gen.}

(Fig. 2.)

Radialramus und Media bilden im Vorder- und Hinterflügel zusammen eine Gabel, im Vorderflïgel ist der Radialramus rerkürzt. Cubitus im Vorder- und

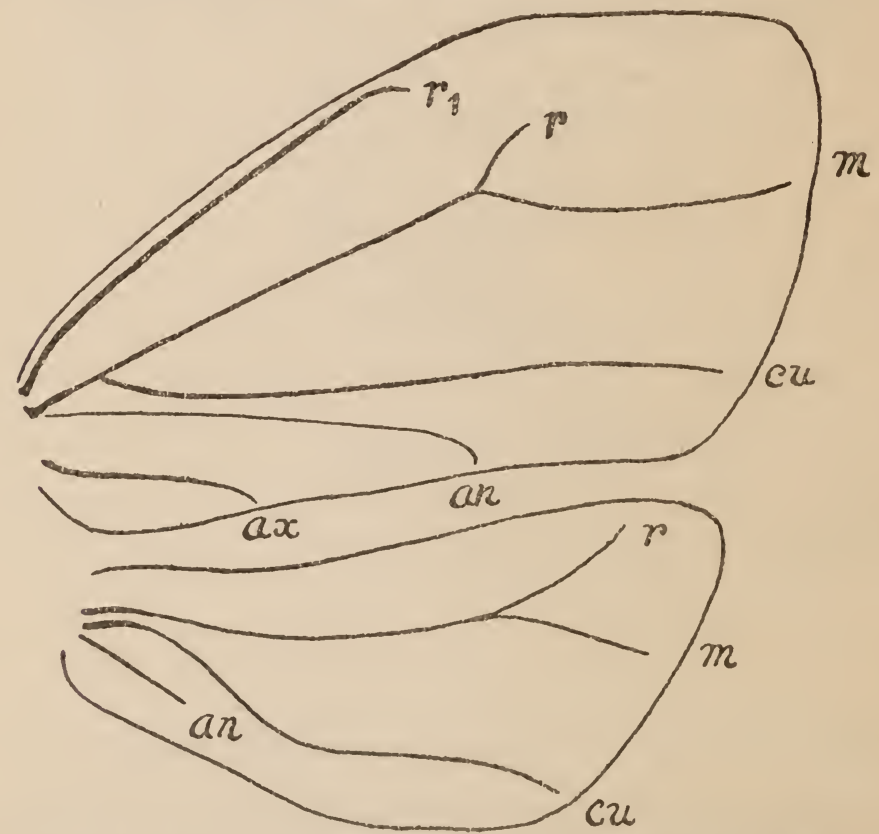

FIG. 2.-Wings of Udamoselis pigmentaria. (Redrawn from Enderlein.)

Hinterfliggel vorhanden, im Vorderfliigel aus der Media nahe der Basis, im Ilinterfliigel dicht neben der Wurzel der Media entspringend. Analis (an) im Vorderflïgel als feine, aber sehr scharfe helle Linie (sutura clavi), in Hinterfligel woniger deutlich. Axillaris $(a x)$ im Vorderfliggel als dentliche Ader entwickelt, sie fehlt im Hinterflügel. Abdomen sehr lang und dunn ( $\hat{o}$ ).

In der Mịtte der Stim ein ziemlich grösser kegelförmiger Höcker. Jede der beiden grossen Ocellen liegen dicht dem Innenrand der Augen nane am Hinterrand des Scheitels an.

Type, pigmentaria Enderlein. 
[Translaticn.]

UDAMOSELIS nor. gen.

(Fig. 2.)

The radial ramus and the media both in the fore and hind wings form a branched fork; in the forewing the radial ramus is shortened. The cubitus is present both in the fore and the hind wing; in the forewing it has its origin in the media near its base, in the hilid wing it starts close to the root of the media. Analis visible in the forewing as a fine but very distinct bright line (sutura clavi), in the hind wing it is less distinct. The axillary $(a x)$ is developed as a distinct rein in the forewing; in the hind wing it is wanting. The abdomen of the male insect is very long and attenuated.

In the middle of the front of the head there is a rather large coneshaped protuberance. Each one of the two large ocelli lies close to the internal margin of the compound eyes near the posterior margin of the occiput.

The terminology of wing-veins used by Dr. Enderlein in the preceding diagnosis does not correspond with our ideas on the subject. As discussed under "The wings," we consider the costa as represented by the margin, and the "fork" as formed by radius ${ }_{1}$ and the radial sector. Below we tabulate, therefore, Dr. Enderlein's terms, giving in each case what we consider the correct term:

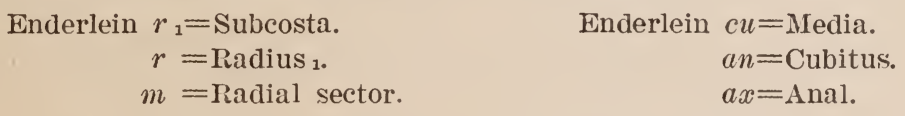

Udamoselis pigmentaria Enderlein.

(Fig. 2.)

Udamoselis pigmentaria Enderlein, Zoologischen Anzeiger, Bd. 3t, No. $7 / 8$, p. 231 (1909).

ORIGINAL DESCRIPTION.

ô. Kopf sehr klein, breiter als lang, kaum so breit wie die Hälfte der Thoracalbreite. Augen sehr gross, blassgelblich, jedes Auge nimmt 1/3 der Kopfbrreite ein und ist von Kopflänge. Scheitel blassgelblich, äusserster Hinterrand in der Mitte schwarz, Scheitelnaht sehr tief, der Hinterrand ziemlich tief stumpfwinkelig ausgeschnitten; die beiden Scheitelhälften klein, etwas länger als breit. Die beiden Basalglieder der Fühler ziemlich dick und braun, Fühlerinsertion zur Hälfte in den Augenrand eingerückt, der Augeninnenrand an dieser Stelle schmal und tief eingebuchtet, Einbuchtung viel tiefer als breit. (Fühlergeissel abgebrochen). Den Zwischenraum zwischen den Fühlerinsertionen füllt ein grosser ziemlich hoher kegelförmiger schwarzer Stirnaufsatz. Clypeus relativ gross, in Gestalt eines gleichseitigen Dreiecks, dessen eine Ecke nach vorn gerichtet ist, rostgelb, mit ziemlich langen und ziemlich dichtstehenden, senkrecht abstehenden 
braunen Haaren besetzt. Rüssel etwas länger als die Kopfhöhe, die beiden Glieder etwa gleichlang, 1. Glied gelblich, am Ende bräunlich;2. Glied gelblich, Endhälfte sclhwarz, nach der Spitze zu allmählich zugespitzt. Wangen sehr liurz, nur vor den Augen, Schläfen fehlen.

Thorax rostbraun, Scutellum und Postscutellum bräunlichgelb. Pronotum kurz, Hinterrand in der Mitte etwas flach eingedrückt. Mesonotum sehr kräftig und dick, hoch gewölbt; Antedorsum schmal, nach hinten lang und spitz ausgezogen und gewölbt, und durch tiefe Parapsidenfurchen abgesetzt; die beiden Seitenflügel der Dorsa in der Mitte kurz vereinigt und durch kleine Furche getrennt; Scutellum als Querwulst, die etwa $2 \frac{1}{2} \mathrm{mal}$ so breit wie lang ist. lich ist das Postscutellum, nur etwas kleiner. Der Hinterrand des Scutellum und Postscutellums setzt sich jederseits in eine scharfe Querleiste fort. Das Andorsum des Metanotum ist fast so gross wie das des Mesonotum, und ist durch eine sehr scharfe Medianfurche in 2 Hälften zerlegt. Auch die Dorsa des Metanotum sind in der Mitte nicht voneinander abgesetzt. Hinter dem Postscutellum fïllt es hinten steil ab.

Abdomen sehr lang und schmal; die sieben ersten Glieder kurz, etwas flach, fast $1 \mathrm{~mm}$. breit und neben den Seiten oben mit Längsfurche; S. und 9. Segment schmäler, röhrenförmig, 8. so lang wie breit, 9. etwa 4 mal so lang wie breit. 1. Tergit kurz, in der Mitte mit drei ziemlich dichstehenden feinen, aber scharfen Längskielen; 2. Tergit mit einem ebensolchen Mediankiel. S. Tergit nach hinten «u etwas steil ansteigend. Am Ende des 1. Drittels der Oberseite des 9. Tergites ein kleiner Höcker, der hinten eingedrückt ist. 1. Sternit sehr kurz, mit feinem Mediankiel; 2. Sternit mit zwei dicht gedrïngten Mediankielen; 3. Sternit vorn mit einem kleinem, flach dreieckigen, etwas eingesenkten Feld, von dem jederseits ein feiner, aber scharfer Kiel ausgeht, beide dirergieren nach hinten zu und stehen senkrecht zueinander; beide Kiele setzen sich geradlinig an ciem 4. Sternit bis zu den Hinterecken fort. Zangen (des $\hat{o}$ ) sehr schlank oval und sehr lang, etwas mehr als $\frac{2}{3}$ des 9 . Segments. Penis kurz. Abdomen oben bräinlichgelb. Mitten der Tergithälften des 2. Tergits mit schwärzlichem Wisch, 8. Tergit schwarz äusserster Hinterrand fein brïunlichgelb gesiiumt; unten bräunlichgelb mit graubriunlichem Hauch.

Beine ziemlich klein und zart, sehr spärlich und kurz pubesziert; blass bräunlichgelb. Schenkel mit kleinen braunen Punkten besprenkelt. Schienen und Tarsen dünn. ausserste Spitze der Schienen und des 1. Tarsengliedes blassbraun, Endhälfte des 2. Tarsengliedes schwarz; die beiden Klanen klein und ziemlich zart, rostgelb. Ein Empodialanhang (Paronychium) ist mit der Iupe nicht erkennbar. Hinterschiene etwas länger als die übrigen, die Tarsenglieder bei allen Beinen fast gleich, und zwar das zweite ungefähr $\frac{2}{3}$ des ersten. Die beiden Tarsenglieder sind zusammen ungeführ die Ïalfte der schiene. Klauenlïnge ungef:ihr $\frac{1}{3}$ der Läinge des 2. Tarsengliedes.

Flügelspitzen beider Flügel ziemlich eckig, aber abgerundet. Die Gabel fast rechtwinkelig in Vorderflügel, spitzwinkelig im Hinterflügel. Clavus im Vorderflïgel gross, bis in die Mitte des Hinterrandes reichend; im Hinterflügel klein, etwa bis zum Ende des ersten Viertels des Hinterrandes reichend. Vorderfliugel relativ breit, Hinterfligel ziemlich schmal, besonders im Basalteil. Cubitus im Ilinterflügel gebogen.

Fliggelfirbung und Zeichnumg auf der Ober- und Unterseite gleichmässig. rirundfarbe des Vorderflïgels ockergelb, nit feiner verwaschener bramer Sinrenkelung, die nur an folgenden Stellen fehlt: ein ziemlich grosser, halbkreisfürniger, mit der Basis dem Aussenrande aufliegender Fleck an der Mündung 
von $m$, ein ebensolcher am Vorderrand dicht vor des Spitze, ein ebensolcher etwas grösser an der Mündung von an, der den Cubitus nahezu tangiert, ein weiterer, etwas kleinerer und verwaschener dicht neben diesem in der Mitte des Hinterrandes und ein nahezu kreisrunder in der Mitte zwischen der Radialgabelungsstelle und dem Cubitus. Zwischen den beiden hellen Flecken am Flügelhinterrand ein ziemlich dunkelbrauner Fleck. Hinterflügel ziemlich dicht und dunkelbraun besprenkelt, Spitze etwas lichter; am Vörderrande am Ende des 1. und am Ende des 2. Drittels je ein grüsserer ockergelber F'leck. Flügel völlig matt, ohne jeden Glanz, ohne Pubescenz und ohne Bestäubung.

Vorderflïgellïnge $5.5 \mathrm{~mm}$.

Hinterflügellänge $3 \frac{3}{4} \mathrm{~mm}$.

Körperlänge $7 \mathrm{~mm}$.

Abdominallänge $4 \frac{3}{4} \mathrm{~mm}$.
Thoracalbreite, $1 \frac{1}{2}$ mm.
Iänge des 9 . Segmentes $1 \frac{3}{4} \mathrm{~mm}$.
Zangenlänge $1 \frac{1}{4} \mathrm{~mm}$.

Vaterland: wahrscheinlich Südamerika. 1 ô.

[Translation.]

Male.-Head very small, wider than long, hardly as wide as onehalf of the thoracic width. Compound eyes very large, pale yellow; each compound eye occupies one-third of the width of the head and equals the head in length. Vertex pale yellow, its extreme posterior margin black in the center. Epicranial suture very deep, the posterior margin deeply cut. The two halves of the vertex small, somewhat longer than wide. The two basal joints of the antennæ rather thick, and brown; the insertion partly in the margin of the compound eyes. The interior margin of the compound eyes deeply sinuate at this place, the sinus being much deeper than wide. (Remainder of the antennæ broken off. $)^{\circ}$ The interval between the insertions of the antennæ is occupied by a large, rather high, cone-shaped, black frontal protuberance. Clypeus relatively large, in the form of an equilateral triangle; one angle being turned to the front, rusty yellow, provided with brown hairs that are rather long and more or less close together, standing off at right angles. Proboscis somerrhat longer than the height of the head, the two joints nearly equal in length. First joint yellowish, brownish at the end; second joint yellowish, black at the end, and gradually coming to an acuminate point. Cheeks very short, only in front of the eyes, "temples" not present.

Thorax reddish brown, scutellum and postscutellum brownish yellow. Pronotum short, its posterior margin having slight flat depression in the center. Mesonotum very robust and thick, highly arched. Antedorsum narrow, attenuated toward the rear end and arched and set off by deep parapsidal furrows; the two lateral wings. of the dorsa united in the middle for a short distance and separated by a small groove. Scutellum in the form of a cross welt which is 
about two and one-half times as wide as it is long. Postscutellum very similar in shape, but somewhat smaller in size. The posterior margin of the scutellum and the postscutellum is continued on each side by an acute crosswise welt. The andorsum of the metanotum is almost as large as that of the mesonotum and is divided by a very sharp median furrow into two halves. The dorsa of the metanotum are likewise not set off from each other in the center. Behind the postscutellum there is an abrupt declivity.

Abdomen very long and narrow; the first seven segments are short, somewhat flat, almost $1 \mathrm{~mm}$. in width, and having along their sides a superior longitudinal furrow; eighth and ninth segments narrower, tubuliform; the eighth as long as it is wide; the ninth about 4 times longer than wide. First tergite short, provided in its center with three quite distinct, fine, but plainly visible, longitudinal keels. Second tergite with one similar median keel. Eighth tergite somewhat steeply acclivous toward the rear. At the end of the first third of the upper side of the ninth tergite is a small protuberance which is indented in the rear part. First sternite very short, provided with a fine median keel; second sternite furnished with two median keels that are closely crowded together; third sternite provided at the front with a small, flatly triangular, somewhat indented field, from which issues on each side a very fine but distinct lieel. These two keels diverge toward the rear and become perpendicular to each other. Both of these keels are continued in a straight line in the fourth sternite as far as the posterior-covers. Forceps (of the male) narrowly oral and very long, at times exceeding two-thirds the length of the ninth segment. Penis short. Upper side of the abdomen brownish yellow. In the center of the second tergite there is a blackish stripe. Eighth tergite black, its extreme posterior margin bordered by a fine brownish-yellow seam. The ventral side of the abdomen brownish yellow, with a brownish-gray cast.

Legs very small and slender, very sparsely and briefly pubescent, pale brownish yellow. Femur sprinkled with small brown dots. Tibix and the tarsi thin; distal ends of both the tibia and the first tarsal joint pale brown; distal half of the second tarsal joint black. The two claws small and quite slender, rusty yellow. An empodial appendage (paronychium) is not visible under the magnifying glass. Posterior tibia somewhat longer than the others; the tarsal joints in all the legs alınost equal in length, the second being about two-thirds as long as the first. The two tarsal joints are together about onehalf the length of the tibia. Length of the claws about one-third the length of the second tarsal joint.

Ends of both wings somewhat angular, but rounded off. The bifurcation almost rectangular in the forewing, but acute-angled in the 
hind wing. Club in the forewing large, extending as far as the middle of the posterior margin. Forewings relatively broad, the hind wings rather narrow, particularly in the proximal part. Cubitus in the hind wing curved.

Color of the wings and markings on the upper and lower sides uniform. Basal color of the forewing ochraceous yellow, with a rather finely increscent brown sprinkling, which is wanting only in the following locations: A pretty large semicircular spot, its base resting on the exterior margin at the mouth of an; another spot at the anterior margin close before the point; a still larger spot near the embouchure of an, which almost touches the cubitus, and furthermore a smaller spot close beside the cubitus in the middle of the posterior margin; finally, an almost circular spot in the middle between the cubitus and the point of bifurcation of the radial vein. Between the two light-colored spots on the posterior margin of the wings there is a spot of rather dark-brown color. Hind wings sprinkled densely with dark-brown spots. Their apices somewhat lighter in color. There is a large ochraceous spot along the anterior margin at the end of the first third and another at the end of the second third of its length. Wings quite colorless, without any luster, without pubescence, and without any powdering.

Length of forewings $5.5 \mathrm{~mm}$.; length of hind wings $3.75 \mathrm{~mm}$.; length of body $7 \mathrm{~mm}$.; length of abdomen $4.75 \mathrm{~mm}$.; width of thorax $1.5 \mathrm{~mm}$.; length of the ninth segment $1.75 \mathrm{~mm}$.; length of forceps $1.25 \mathrm{~mm}$.

Habitat.-In all probability South America. One male.

\section{Subfamily Aleurodicinde n. subfay.}

The members of this subfamily are characterized by the presence in the forewing of the radial sector and media. Radius ${ }_{1}$ may or may not be present, and the cubitus is rarely faintly indicated.

The type genus is Aleurodicus.

Four genera are at present included in the subfamily, which may be separated as follows:

\section{Genera of the Aleurodicina.}

A. Pupa case without large compound pores. Forewing with radius and media well developed; vertex produced; lingula included; antennæ of seven segments

Dialeurodicus.

B. Pupa case with no compound pores, but with agglomerate pores; radius 1 and media well developed; antennxe of seven segments_---_Leonardius.

C. Pupa case with large compound pores; radius ${ }_{1}$ and media well dereloped; antennæ of seven segments Aleurodicus.

D. Pupa case with compound pores; radius ${ }_{1}$ absent; media considerably re= duced; antennæ of four segments

Paraleyrodes. 


\section{Genus DIALEURODICUS (Cockerell) n. gen.}

Forewing with radius ${ }_{1}$, radial sector, and media retained. Vertex produced into a prominent cone-shaped process. Antennæ of seven segments, of which the third is the longest. Paronychium of the foot represented by a stout spine. Pupa case flat; no compound pores present but simple pores, either scattered over the surface or somewhat collected into areas; vasiform orifice small, lingula setose, short conical, included and armed with four spines.

Type, cockerellii Quaintance.

\section{Species of Dialeurodicus.}

I. Dorsum of pupa case with scattered simple pores; large, oval, flat, size about 1.63 by $1.23 \mathrm{~mm}$., yellowish brown; surface without reticulations; wax tubes forming the marginal rim, separated by rather shallow incisions. Adults with large spotted wings__-__cockerellii.

II. Dorsum of pupa case without scattered simple pores; large, oval, flat, size about 1.7 by $1.40 \mathrm{~mm}$. Dark brown to blackish (shiny jet-black on leaf); surface with some reticulations; wax tubes forming margin of rim, separated by deep incisions tessellatus.

III. Dorsum of pupa case with scattered simple pores and a broad subdorsal band all around of closely set simple pores divided by body sutures into six more or less distinct patches. Suborate in shape, size 1.5 by $1.12 \mathrm{~mm}$., marginal wax tubes separated by shallow incisions silvestrii.

IV. Dorsum of pupa case with four pairs of wax-secreting pores on abdominal segments 4 to $\tau$ and a submarginal rim all around of simpie pores. Dorsal disk dark brown, with four radiating patches of same color on each side. Shape elongate, elliptical, narrowed cephalad, size 2.36 by $1.28 \mathrm{~mm}$. Margin of case entire_-__-_____-_pulcherrimus.

\section{Dialeurodicus cockerellii (Quaintance).}

(Pl. IV, figs. 1-14; Pl. VII, fig. 1; text fig. 3.)

Aleurodicus rorkerellii Quaintance, Tech. Series S, Div. Ent., U. S. Dept. Agr., p. 45, (1900).

(IRIGINAL DESCRIPTION.

Pupa casc.-Size about 1.63 by $1.23 \mathrm{~mm}$. ; subovate in shape, smaller end cephalad. Color uniformly yellowish. There is but slight waxy exudation from dorsum. which is more or less mealy. No wax rods have been observed. Dried specimens separate easily from leaf, leaving usually a ring of white mealy wax of the size and shape of case; extending from the periphery inwari are light lines of this mealy wax, more or less distinctly marking the position of the abdominal sutures of the case. Dorsum of pupa case almost flat, but as seen under a hand lens is much wrinkled transversely in dried material. These folds or ridges occur mainly along the body segments and posteriorly become much eurved around the vasiform orifice. Under the microscope the abdominal segments are indistinct and scarcely elevated, except in the medio-dorsal line, where a slight rounded keel may be observed. Margin of case practically en- 
tire. Very slight furrows or thickenings extend mesad a short distance from margin of case, rather marking the margin into more or less distinct rectangular figures. Just within the margin all around is a series of very small disc-like pores, usually one to each of these marginal rectangles. Dorsum roid of well developed setæ, except a pair just within the caudal margin; but there is a pair of small setæ at vasiform orifice, and very minute setæ occur here and there on the dorsum. The five or more pairs of large compound pores, so usual en dorsum of pupa case of Aleurodicus, seem to be absent in this species, but very many minute transparent pores may be detected on dorsum under high power of microscope.

Vasiform orifice subcordate, somewhat longer than wide; cephalic margin straight; at caudal end there is a short, stout, spine-like protrusion. Operculum subrectangular, about half length of orifice; cephalic and caudal margins practically straight, lateral margins rounded; lateral and caudal margins thick; minutely setose. Lingula quite as long as orifice, rery broad, and bearing distally two pairs of setæ, the smaller pair proximad; minutely setose.

Rudimentary legs and antennæ on rentral surface quite distinct. Distal joint of legs with a straight and truncate spine. Antennæ usual, minutely ringed.

A $d u l t$ \%.-Length, about $1.96 \mathrm{~mm}$; forewing, about 2.4 by 1.6 mm. ; length of hind tibia, $0.8 \mathrm{~mm}$; length of hind tarsus, $0 . \tilde{6} 6$ $\mathrm{mm}$.; length of front tarsus, $0.32 \mathrm{~mm}$; color. bright yellow, legs and

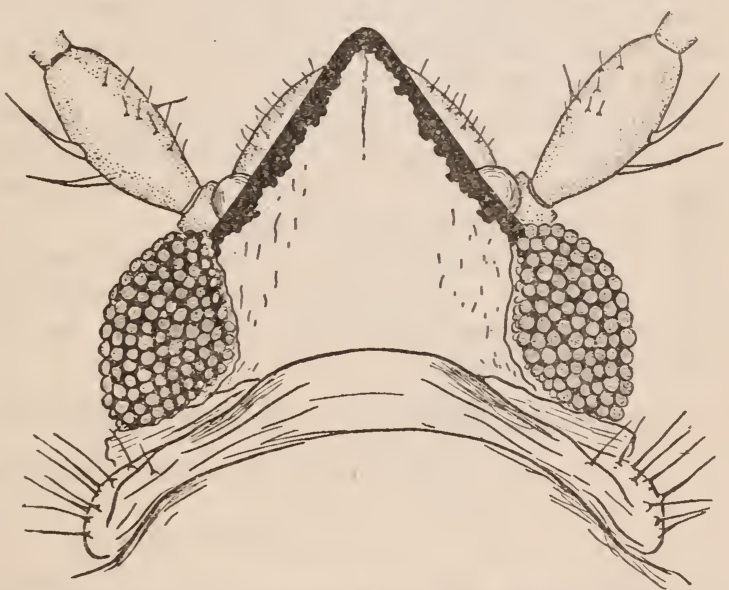

FIG. 3.-Head of Dialeurodicus cockerellii. (Original.)

antennæ paler; wings very broad, and rounded distally. Wings marked with more or less circular spots of brownish black. In forewings, along cephalic margin, are three spots about equidistant, and farther distad, on curre of wing, is a spot somewhat farther from the third spot than are two and three from each other. There is a spot on the margin of outer caudal curve of wing and three spots on the caudal margin, which, howerer, are not equidistant, as in the spots on cephalic margin. Within the area bounded by the distal fork of the rein are two spots, and within the area bounded caudad by the proximal branch are from three to five spots. In hind wings there is a spot on outer cephalic margin. and on the outer caudal margin are two spots. There are two spots in the area bounded by the distal fork of rein, and likewise two spots in the area hounded caudad by the proximal branch of vein. Head as seen from above acute cephalad, and margined with deep reddish or brownish black, continuous with eyes which are of same color. Joint 1 of antennæ short, subcylindrical, distal and irregularly notched or toothed. Joint 2 thick, clubshaped, about three times longer than basal and bearing two or three setæ on outer lateral surface. Joint 3 quite long-quite twice the length of fourth. Distal joint short, terminating in a single seta.

$61201^{\circ}-13-3$ 
Received by the Division of Entomology at Washington from Dr. F. Noack, Instituto Agronomico, Campinas, Estado de S. Paulo, Brazil, on leaves of a myrtaceous plant, March 30, 1898, and again from Dr. Noack, on same plant, June 14, 1898. The writer has also received specimens of this insect from Frof. T. D. A. Cockerell, to whom they had been sent by Dr. Noack. The adults are unique, in the genus Aleurodicus, from the more or less circular spots on the wings. Div. Ent., Nos. 8010 and 8115 . Type pupa-case, S010, described from nine specimens, and specimens on leaf from Prof. Cockerell. Type, adult, 8115, described from two specimens.

Mr. Adolph Hempel ${ }^{19}$ has been able to observe this species in nature, and has added the following interesting descriptive remarks:

Grown larva and pupa yellowish, about 1.87 millim. long and 1.33 millim. wide; very flat; lateral edge thin. Dorsum covered with a dense thick mass of white secretion, arranged in a marginal fringe, and a submarginal oval ring.

Adult male light yellow in color; head, eyes, wings, and anteunæ as in the female Body narrow, 2.21 millim. long. Extent of wings 4.93 millim. Genitalia large, .430 millim. long, forcipate, tips strongly curved. Penis fine, tip curved upward, .190 millim. long.

Eggs small, elongate, slightly curved, light yellowish, with a short peduncle; usually laid in an irregular mass and covered with a fine white powder. The eggs hatch in from 11 to 13 days. The larva stage lasts from 44-16 days, and the pupa stage from 15-16 days.

Hab. Campinas, State of S. Paulo, on the underside of leaves of a cultivated guava (Psidium cattleianum). The entire under surface of the leaves becomes coated with a fine white powder, while the upper surface is usually covered with a black fungus.

\section{Type.-No. 14761, U. S. National Museum. \\ Dialeurodicus silvestrii (Leonardi).}

(Pl. V. figs. 1-6.)

Aleurodicus silvestrii Leonardi, Bollettino del Lab. di Zool. generale e agraria della R. Scuola superiore d'Agricoltura in Portici, vol. 4, pp. $320-322(1910)$.

ORIGINAI, DESCRIPTION.

Larva (ultimo stadio).-Corpo ovale, piatto, un poco piu acuminato all'innanzi che di dietro, provvisto, lungo il margine libero, di una stretta frangia ininterrotta di cera biance nivea.

Al dorso si osservano 6 nastri cerosi bianchissimi, molto vistosi, i quali sono contigui colle loro basi delimitanclo in tal modo un'area centrale di forma esagonale allungata nel senso diametro longitudinale. Quest'area, coperta da pochi glomeruli di cera, viene a costituire, direi quasi, il fondo di un'elegunte cestella i di cui lati sarebbero costituiti dai summentovati nastri cerosi i quali, da prima, si dirigono in alto per pol ripiegarsi, contorti piu o meno, lateralmente.

Denudato l'insetto esso appare di un bel colore vitellino uniforme. I segmenti del corpo somo ben ristinti tra loro specie quelli che costituiscono l'addome. Al dorso, lungo il margine, a breve distanza da esso, si osserva una serie di ghiandole ciripare che corre parallela al margine stesso.

Nell'area mediana dorsale, tutt'all'ingiro, vi sono un gran numero di sbocchi di ghiandole ciripare raccolti in 6 distinti aggruppamenti, de $i$ quali tre sono diposti a destra e tre a sinistra del diametro longitudiuale del corpo dell'insetto. 

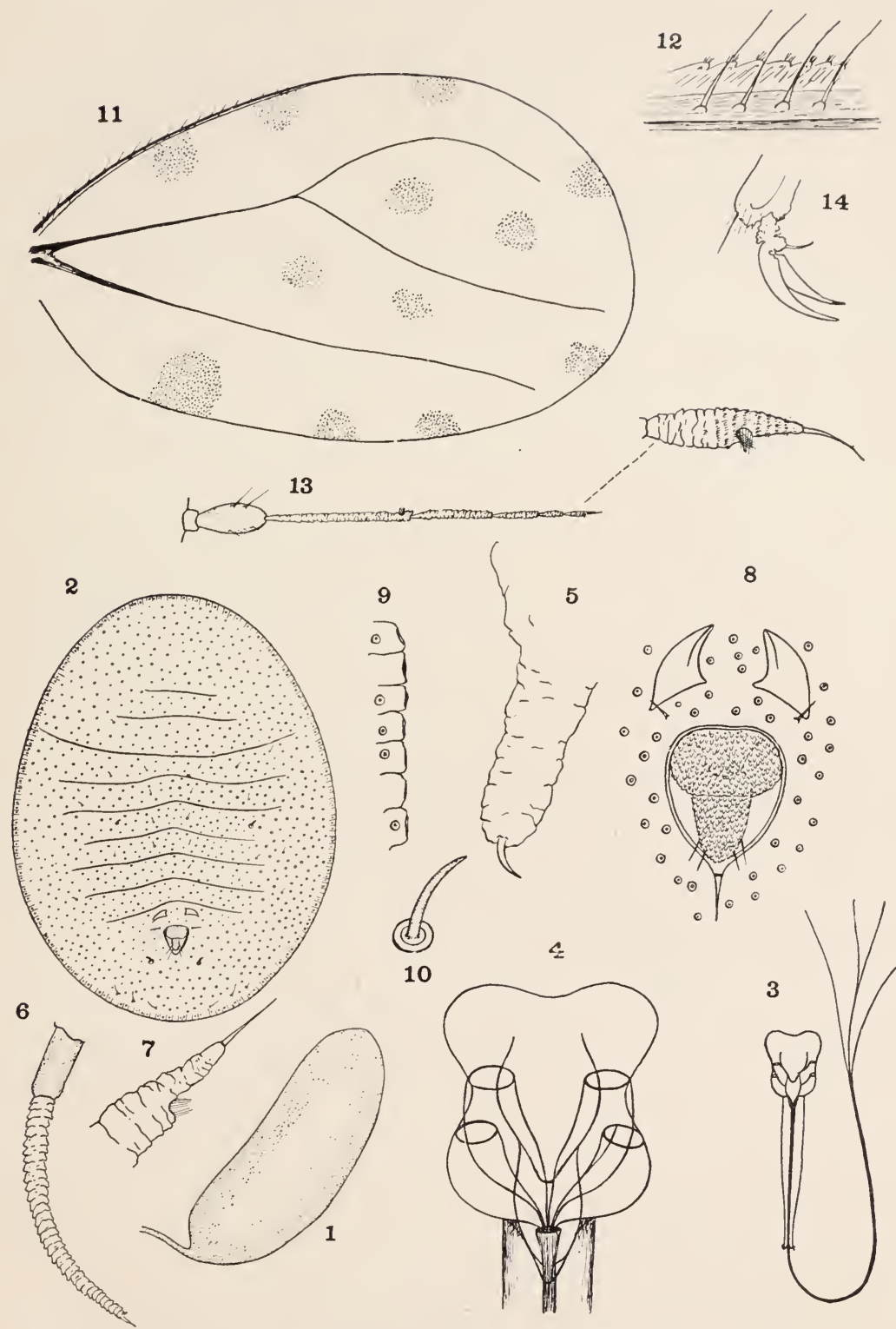

8

DiALEURODICUS COCKERELLII.

Fig. 1.-Egg. Fig. 2.-Pupa case. Fig. 3.-Rostrum. Fig. 4.-Trophic tubercle. Fig. 5.Leg of pupa. Fig. 6.- Intenna of pupa. Fig. 7.-Tip of same. Fig. 8.-Vasiform orifice of pupa. Fig. 9.-Margin of pupa case. Fig. 10.-Dorsal spine of pupa case. Fig. 11.Forewing of adult. Fig. 12.- Costal margin of forewing. Fig. 13.-Intenna of adult. Fig. 14.-Foot of adult. (Original.) 

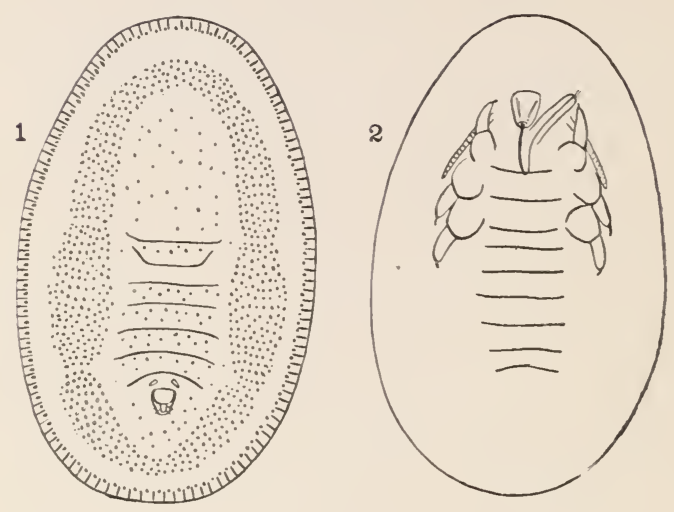

5

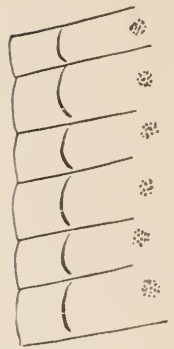

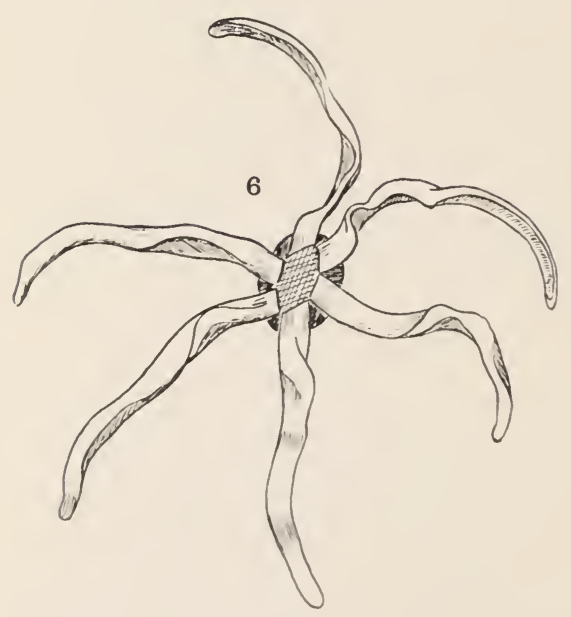
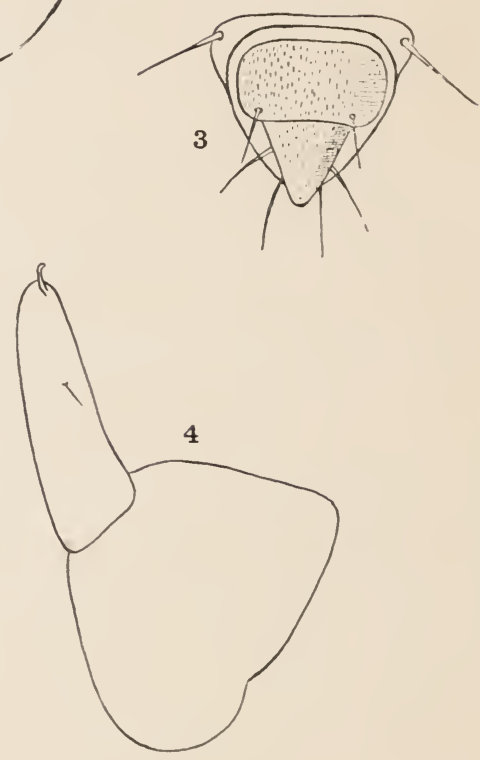

DIALEURODICUS SILVESTRII.

Fig. 1.- P’upa ease, dorsal view. Fig. 2.-Same, ventral view, Fig. 3.-Vasiform orifice

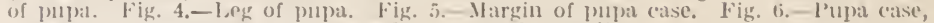
showing wax secretion. (Figures redrawn from Leonardi.) 
L'aggruppamento mediano destro, come il corrispondente di sinistra, sono bene distinti dagli aggruppamenti contigui, di cui i due anteriori, come pure i due posteriori finiscono col confluire tra loro rispettivamente all'apice anteriore ed a quello posteriore del corpo degl'insetto, ove d'altronde i detti aggruppamenti presentano il maggiore ristringimento loro. La cera segregata da si fatte ghiandole ciripare è quella che va a formare i nastri cerosi prima ricordati. Altre ghiandole di simile fabbrica, con disposizione simmetrica, trovansi diffuse sul tegumento compreso tra gli aggruppamenti di cui si è ora tenuto parola, mentre ne è privo, fatta eccezione per la serie di ghiandole circummarginali già descritte, la porzione posta al di là di essi.

L'apertura allale, in confronto di quella della specie precedente, è molto piu ridotta nelle dimensioni e l'opercolo che la ricopre, in paragone, è molto più largo che lungo, la lunghezza, riuscendo, a malo pena più lunga della metà della larghezza. La linguetta per forma, per numero e per disposizione dei peli vistosi di cui è ornata rassomiglia a quella della specie precedente salvo che le dimensioni sono proporzionate a quelle del rispettiro opercolo.

Dal lato del ventre l'insetto non presente nulla di speciale, eccetto le zampe che come nell' Aleurodicus Lahillei portano al loro apice anzichè una ventosa un robusto uncino.

Lunghezza del corpo $1500 \mu$.

Larghezza del corpo $1120 \mu$.

Lunghezza dei nastri cerosi circa $\frac{1}{2}$ centimetro.

Larghezza dei nastri cerosi circa $\frac{1}{2}$ millimetro.

Adulti.-Sconosciuti.

Habitat.-Raccolto a Jalapa (Mexico) su foglie di una pianta rimasta indeterminata.

Gl'insetti per lo più riuniti in numerose colonie, si fissano d'ordinario ai lati della nervatura mediana della foglia disponendosi alternativamente uno di quà e l'altro al di là ai detta nervatura formando nel loro complesso un'elegante disegno che spicca sul verde della foglia grazie alla bianchezza perfetta dei nastri cerosi che si innalzano dal dorso dell'insetto.

\section{[Translation.]}

Larva (last stage).-Body oval, flat, a little more acuminate at the anterior end than at the posterior end, provided along its free margin with a narrow uninterrupted fringe of snowy white wax. At the dorsum there are seen six very white waxy slender tentacles: very conspicuous, which are contiguous at their base, delimiting in this manner a central area of hexagonal shape elongated in the direction of the longitudinal diameter. This area, covered with little globules of wax, constitutes, so to say, the bottom of an elegant cestus ("cestella") the sides of which are formed by the base of the abovenamed waxy tentacles, which at first are directed upward, and then bend down, contorted, more or less, laterally.

When denuded, this insect appears of a beautiful uniform vitelline color. The segments of the body are quite distinct, particularly those that constitute the abdomen. At the back, along the margin, and a short distance from the same, there can be seen a row of wax-producing glands which runs parallel to this margin. 
In the median dorsal area, all around, there are a large number of mouths of wax-producing glands, collected in six distinct groups, of which three are arranged at the right and three at the left of the longitudinal diameter of the body of the insect. The middle group on the right, as well as that on the left, is quite distinct from the contiguous groups, of which the two anterior ones, as well as the two posterior ones, unite respectively at the anterior apex and at the posterior apex of the body of the insect, at which points these groups are of their smallest width. The wax secreted by these wax-producing glands is that which goes to form the above-recorded six waxy tentacles. Other glands of similar nature, symmetrically disposed, are found spread out upon the tegument comprised between the groups of which we have just spoken, but such glands are wanting, with the exception of the row of circummarginal glands already described, on the part of the tegument outside of the principal groups.

The anal aperture, as compared with that of the preceding species, is much smaller in size, and the operculum which covers it is, in comparison, much wider than long, the length being scarcely more than one-half of the width. The lingula, by its shape and by the number and disposition of the sightly hairs with which it is ornamented, resembles that of the preceding species except that the dimensions are proportionate to those of the respective operculum.

As regards the venter the insect presents no special features except the legs which, like those of Aleurodicus lahillei, carry at their apex a robust claw rather than a pulvillus.

Length of body $1.500 \mathrm{~mm}$.; width of body $1.120 \mathrm{~mm}$.; length of the waxy tentacles about $5 \mathrm{~mm}$.; width of the waxy tentacles about $0.5 \mathrm{~mm}$.

Adults.-Not known.

Habitat.-Collected at Jalapa, in Mexico, upon the leaves of a plant the species of which is undetermined.

The insects, for the most part collected in numerous colonies, are ordinarily attached to the sides of the middle vein of the leaf, disposed alternately on the one and the other side of this vein, forming in their totality an elegant design which shines upon the verdure of the leaf, thanks to the perfect whiteness of the waxy tentacles which arise from the back of the insect.

\section{Dialeurodicus tessellatus n. sp.}

(Pl. VI, fig. 1; Pl. VII, fig. 2.)

From Ceara, Brazil, on Eugenia mitchelli. Received January, 1906, from Mr. F. Richa. This species in the pupal stage closely resembles I). coclicrellii, but differs in the character of margin of case, in the vasiform orifice, absence of wax pores on dorsum, and darker color of eggs and pupa case. 
DESCRIPTION.

Egg.-Length about $0.32 \mathrm{~mm}$; color shiny brown or blackish, without markings; stalk short (Pl. VI, fig. 1).

Pupa case.-Size about $1.7 \mathrm{~mm}$. long by $1.40 \mathrm{~mm}$. wide; case flat, applied closely to leaf, the body segments distinct as transverse ridges; color, under hand lens, shiny dark brown or blackish (Pl. VI, fig. 2).

The specimens in hand show no waxy secretions from dorsum of case nor from the marginal wax tubes. The larva have a narrow fringe all around the white wax from the marginal wax tubes. Under microscope, pupa casedorown, the more central portion darker; lighter bands, more evident on the sides, extending transversely across dorsum, marking the segments.

Case without the compound wax pores present in Aleurodicus, and the simple wax pores, scattered over dorsum in cockerellii, are, in the present species, absent. There are, however, numerous minute clear points over entire dorsal surface, some occurring singly and others in pairs, one of which is smaller (Pl. VI, fig. 7). The marginal wax tubes are quite distinct; the incisions deep and acute, notably more so than in cockerellii. Just within the margin all around is a series of simple wax pores on the marginal wax tubes. (Pl. VI, fig. 8.)

Case very flat, the lighter specimens showing a coarse network of darker lines on dorsal surface (Pl. VI, fig. 2) ; margin without spines or setæ. Vasiform orifice cordate, about as broad as long; caudal end terminating in a subcircular orifice or pore; operculum subrectangular, the sides rounded and margins straight-about twice as wide as long. Lingula not exserted, stout, subspatulate, bearing two pairs of spines. (Pl. VI, fig. 6.) On ventral surface, legs, antennæ, and rostrum quite distinct; antennæ rather short, ending in a fingerlike process; rostrum unusually well developed, being about $0.18 \mathrm{~mm}$. long; legs short, stout, ending in single hook. (Figs. 3-5.)

Adults.-Unknown.

Type.-No. 14762, U. S. National Museum. Described from several pupæ in balsam mounts and specimens on foliage.

Dialeurodicus pulcherrimus n. sp.

(Pl. VIII, figs. 1-8.)

This species differs from the typical form in the genus by having the frons produced acutely and extending beyond the cone of the vertex. The shape of the pupa case is also somewhat different from that of cockerellii. The general characters, however, seem to approach most nearly to those of Dialeurodicus. 


\section{DESCRIPTION.}

Pupa case (Pl. VIII, fig. 1).- Shape elongate elliptical, considerably narrower cephalad than cauded; dorsum somewhat rounded, with the abdominal segments distinct, the sutures very plainly marked on the subdorsal area. Vasiform orifice (Pl. VIII, fig. 2) subcordate, as wide as long, with the anterior margin straight; operculum transverse, considerably wider than long, the caudal margin straight but indented at each side, as shown in the figure; on each side of caudal margin, just at base of this indentation, a small seta is situated. Lingula short, conical, and forming together with the operculum almost a perfect cone. Its tip is armed with two pairs of large setw and both operculum and lingula are minutely setose. Margin (Pl. VIII, fig. 3) entire and just within it all around is a row of simple wax pores. On the subdorsal area are four pairs of wax pores, one pair on each of segments 4 to 7 . These pores (Pl. VIII, fig. 4 ) have a clear rim and a central dusky area with a dentate margin. Placed irregularly near these are also noticed a number of minute, clear, pore-like areas.

The case, under the microscope, is transparent, with the exception of a central dark-brown region and four radiating bands of the same color on each side, the position of which are shown in Plate VIII, figure 1. A narrow, colorless, central longitudinal band is present on segments 3 to 8 , inclusive. Each of the dark radiating bands has extending through its center a darker line and the marginal pores are closer together on the dark areas than elsewhere. Size of case $2.368 \mathrm{~mm}$. by $1.28 \mathrm{~mm}$.

Adult female.-Head (Pl. VIII, figs. 6 and 7 ) with the rertex produced into a cone-like process; frons also produced into a similar process, which extends beyond it; lower portion of the frons and face armed with numerous spines. Compound eyes dark brown, constricted in the middle; ocelli prominent, bordered by a dark red area. The antennæ are absent from the specimens at hand. Fore-wing (fig. 4) shaded with brown and mottled with a darker shade of the same color as shown in figure. The extent and intensity of these maculations varies somewhat with the individual; veins brown, the cubitus represented by a transparent "fold;" proximal portion of costal margin armed with stiff hairs and entire margin with small projections on which setæ are situated. Size $2.38 \mathrm{~mm}$. by $1.504 \mathrm{~mm}$. Hind wing with brown maculations, as shown in Plate VIII, figure 4; the proximal portion of the costal margin with usually eleven prominent bristles. Size $1.92 \mathrm{~mm}$. by $0.704 \mathrm{~mm}$. Paronychium of foot (Pl. VIII, fig. 8) armed with a prominent bristle. Lingula of rasiform orifice broad and rounded. Length from vertex to tip of ovipositor $1.91 \mathrm{~mm}$.; fore-tibia $0.48 \mathrm{~mm}$. ; hind tibia $0.8 \mathrm{~mm}$. Color 


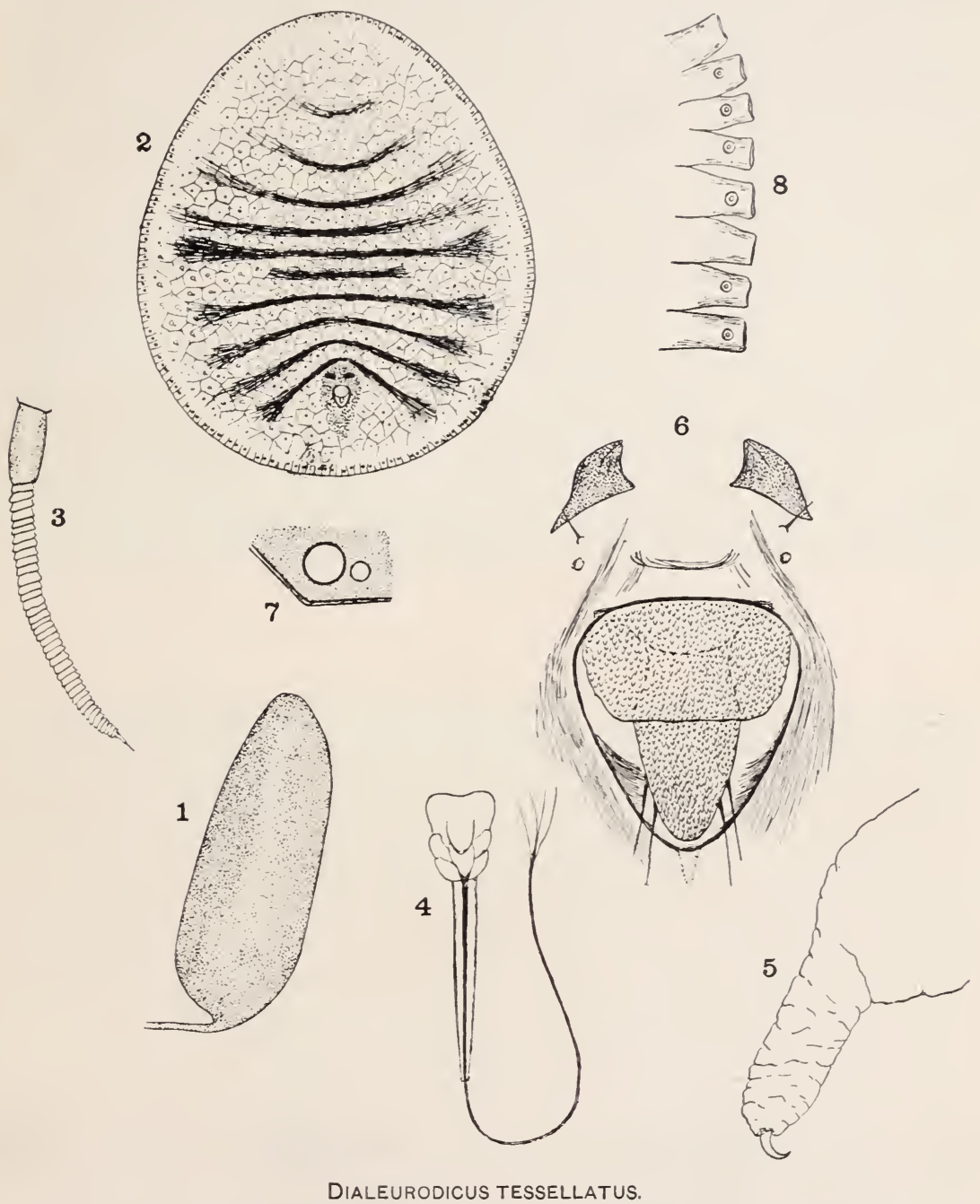

Fig. 1.-Egg. Fig. 2.-Pupa case. Fig. 3.-Antennæ of pupa. Fig. 4.-Rostrum of pupa. Fig. 5.-Leg of pupa. Fig. 6.- Vasiform orifice of pupa. Fig. 7.Paired pores of dorsum of pupa case. Fig. 8.-Margin of pupa case. (Original.) 


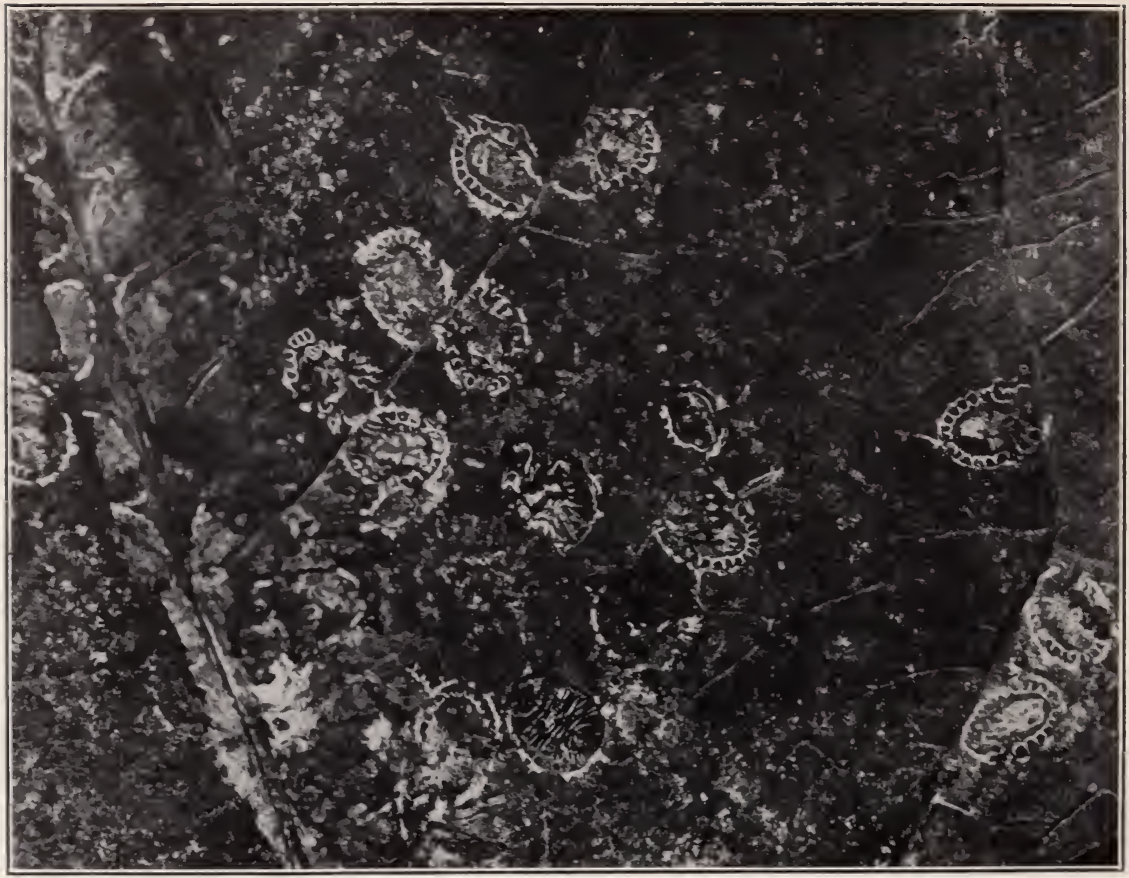

Fig. 1.-Pupe and Waxy Secretion of Dialeurodicus cockerelli on Leaf. (Original.)

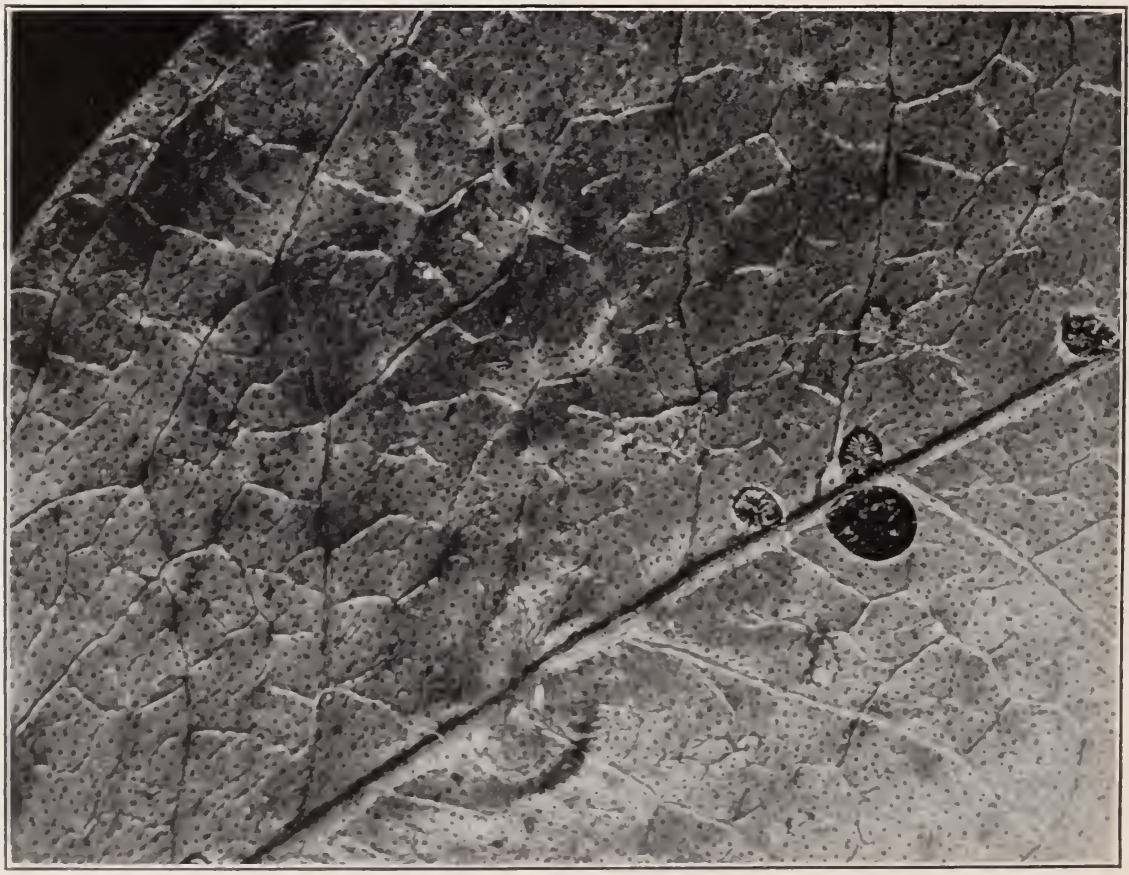

Fig. 2.- Pupe of Dialeurodicus tessellatus on leaf. (Original.) 


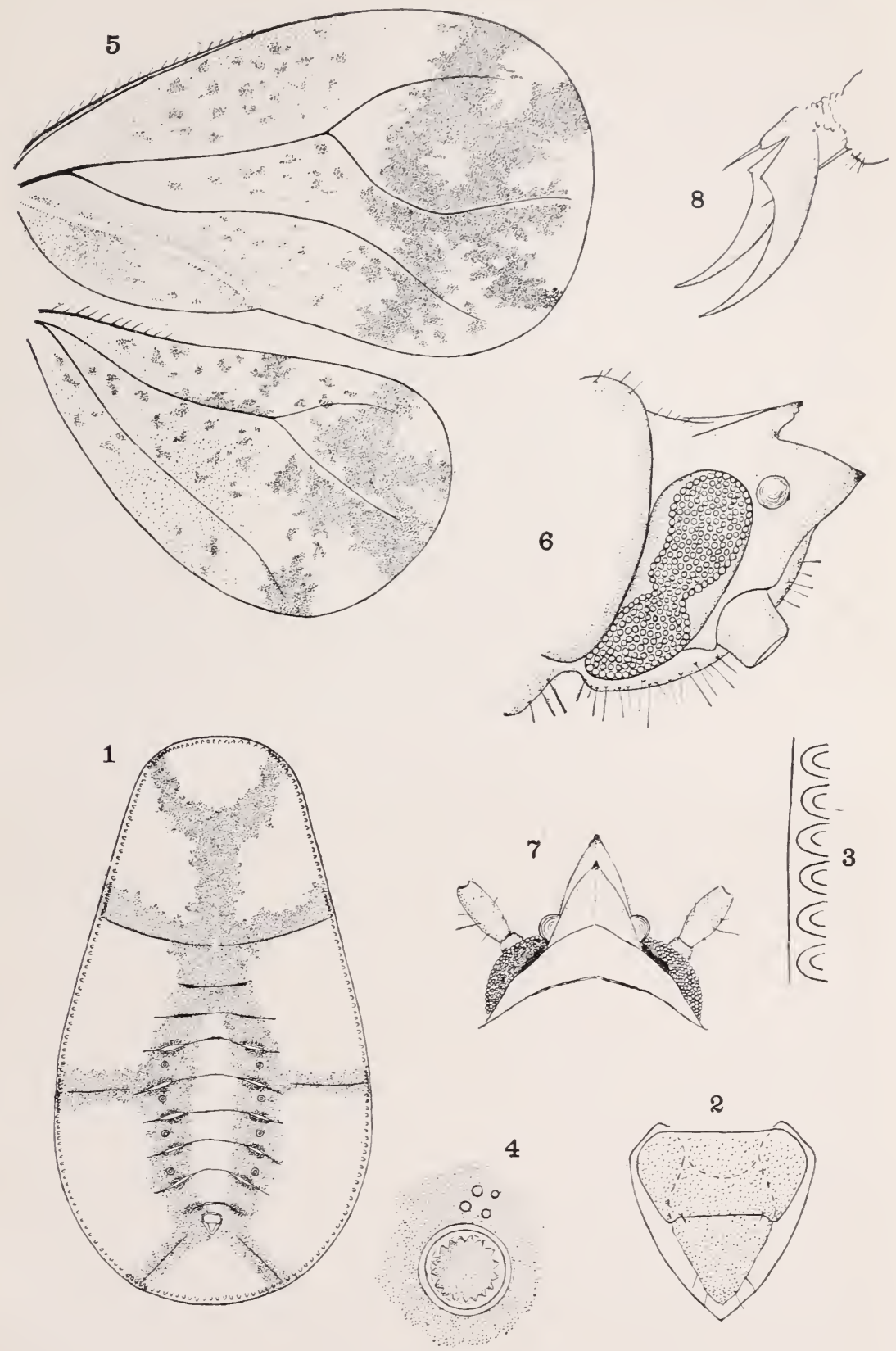

DIALEURODICUS PULCHERRIMUS.

Fig. 1.-Pupa case. Fig. 2.-Vasiform orifice of pupa case. Fig. 3.-Margin of pupa case. Fig. 4.-Subdorsal pores of pupa case. Fig. 5.-Wings of adult. Fig. 6.-Head of adult, lateral view. Fig. 7.--Head of adult, dorsal view. Fig. 8.-Foot of adult. (Fig. 7 less enlarged than Fig. 6.) (Original.) 

yellowish brown; shaded on the thorax, the dorsum of the abdomen, and the articulations of the appendages with dusky to brown.

I/ale.-Unknown.

Type--No. 14778, U. S. National Museum. Described from five females in balsam and two pupa cases, one in balsam and one dry upon the leaf. Taken by Dr. F. W. Urich on coconut in Trinidad.

\section{Genus LEONARDIUS n. gen.}

Forewing with radius ${ }_{1}$, radial sector, and media forming the veins; cubitus present in freshly emerged wing and traces of it sometimes present later; form of wings rounded, color generally mottled. Vertex produced, somewhat cone-shaped. Antennæ of seven segments of which the third is the longest. Paronychium a narrow spined process; púpa case with a series of agglomerate pores, some of which (the two anterior abdominal pairs) take on the nature of compound pores. Lingula of pupa case conical, included, setose, and armed with four spines.

\section{Type, lahillei Leonardi.}

This genus is related to Dialourodicus in the acute vertex and the wing form of the adult and in the character of the vasiform orifice of the pupa case. The tendency toward the development of compound pores in the pupa shows its relation to Aleurodicus.

\section{Leonardius lahillei (Leonardi.)}

(Pl. IX, figs. 1-14; text figs. 4, 5.)

Aleurodicus lahillei Leonardi, Bollettino del Laboratorio di Zoologia generale e agraria della $R$. Scuola superiore d'Agricoltura in Portici, vol. 4, p. 316 (1910).

\section{ORIGINAL DESCRIPTION.}

Larva (ultimo stadio).-Corpo di forma decisamente ovale con polo anteriore appena un po' più acuminato del posteriore, leggermente convesso e circoscritto, lungo il margine, da uno strato, abbastanza cospicuo, di secrezione cerosa biancogrigiastra, sulla quale viene a poggiare l'orlo libero del corpo dell'insetto. Il corpo di questi, lungo il margine ibero, e noterolmente ispessito e presenta tutt' all'ingiro una frangia cerosa ininterrotta e molto breve. Al dorso l'insetto è rivestito da altri glomeruli cerosi e di più presenta, ancora, verso la regione mediana di esso, 4 filamenti cerosi molto lunghi e robusti come si può rilevare dalla (fig. 1).

Eliminata la cera, che piu o meno bene riveste la superficie del corpo dell' insetto, questo, appare di una tinta ferruginea più oscura lungo la regione marginale che non sia verso la regione mediana.

Di più si nota ancora che la regione cefalica del corpo non è ben distintr dal torace quanto quest'ultimo dall'addome, come i segmenti toracici, in confronto degli addominali, sono meno bene separati tra loro.

La consistenza del tegumento dorsale non è uniforme, ma, al contrario, essa mostra delle zone. variabili in dimensioni, in cui la cuticola è assai esile ed 
incolora e tali zone corispondono ad aggruppamenti di numerose e minuscole ghiandole ciripare che colla loro presenza conferiscono a quelle l'aspetto di tante membrane cribrose. Dette zone possiamo distinguerle in due categorie a seconda delle loro dimensioni e tanto le une che le altre, rispetto al diametro longitudinale del corpo, hanno disposizione di perfetta simmetria. Il numero delle zone maggiori è di 7 paia cosi disposte: Un paio situato nella regigne cefalica, un paio sul secondo segmento addominale, un'altro sul IV segmento addominale e gli altri distribuiti un paio per caiscuno dei successivi anelli. Il secondo e terzo paio rappresentano le zone più vistose e sono caraterizzate per presentare, verso il centro, lo sbocco di una grossa ghiandola ciripara provrista di un robusto processo chitiniso conico, più o meno curvato, sul quale viene a modellarsi il lungo filamento ceroso prima ricordato ; le zone successive diminuiscono in dimensioni man mano che si riprocede verso l'estremità posteriore.

Le zone della seconda serie, sono, come si é già osservato, assai meno cospicue e si trovano distribuite particolarmente nella regione cefalica conforme quanto vedesi nella fig. 2 , no. 1 .

Parallelamente al margine del corpo, a breve distanza da esso, corre tutt' all'ingiro una corona di brevi peli distribuiti simmetricamente; un'altro paio di peli cosi fatti possiedono ancora i segmenti toracici ed uno la regione cefalica. I segmenti dell'addome presentano pochi sbocchi di minute ghiandole ciripare anch'esse disposte in serie ora semplice ora duplice.

L'apertura anale presenta l'opercolo piuttosto ampio, poco più largo che lungo con linguetta conica, ottusa all'apice e provvista verso l'estremita, ai lati, di due paia di setole lunghette e abbastanza robuste; un'altro palo di peli meno vistosi sta piantato sull'opercolo, uno a destra e l'altro a sinistra della base della linguetta.

Dal lato de ventre l'insetto non presenta alcunchè di particolare, salvo le zampe rudimentali che diversamente di quanto si nota nelle forme del genere Aleurodes non sono provviste al loro estremo, come quelle, di una grossa ventosa, ma semplicemente di un robusto uncino.

Questo carattere, supnongo, deve essere costante per le specie che rientrano nel gruppo degli Aleurodicus, poichè lo riscontrai anche nella specie che descriverò in appresso, la quale non v'ha dubbio sia un'autentico Aleurodicus, presentando ben distinti tutti i caratteri specifici che servono a tener distinte le forme che compongono detto gruppo dagli altri. Se esso sari convalidato, ripeto, da altre osservazioni potrà fornire un'ottimo carattere diagnostico tutte le volte che per la mancanza delle forme adulte lo stadio corrispondente a quello ora descritto presenti gli altri caratteri poco spiccati di maniera da lasciare lo studioso in dubbio circa il posto da assegnare alla specie.

Tunghezza del corpo $1520 \mu$.

Larghezza " " $1000 \mu$.

Filamenti cerosi lunghi oltre un centimetro.

$$
\text { “ " }
$$

Lunghezza del processo conico che sorregge il filamento ceroso $200 \mu$.

Adulto ․- Forma generale del corpo conforme quella delle specie congenerí. Ali bene sviluppate, le anteriori molto pii ampie delle posteriori, rivestite da una tenuissima secrezione cerosa biancastra.

Tanto le ali anteriori che quelle posteriori presentano numerose macchie brunastre, di sviluppo vario ed a contorni piu o meno frastegliati conforme (quanto osservasi nella fig. 2 , No. 8 .

Zampe piuttosto lunghe, mediocremente robuste, disuguali tra loro essendo pin breve il paio auteriore. Ia variabilitì della lunghezza delle zampe e dovuta specie alla maggiore lunghezaa che raggiungono tra tutti gli articoli 
la tibia ed il tarso, giacché anca, trocantere e feorme in tutte e tre le paía di zampe sono di egual lunghezza. Tutti gli articoli (lella zampe sono formiti di peli i quali nel complesso sono brevi ed esili, i più delicati, ma nunerosi, sono quelli inseriti sull'anca, mentre i più robusti, per quanto brevissimi, sono quelli piantati sulla tibia Ia quale, verso il suo apice distale, presenta ancora due suroni di discrete dimensioni. Il tarso al suo, apice è armato di due lunghe e robuste unghie di cui una al suo margine interno è unidentata, mentre l'altra è iuerme. Tra le due unghie vi ha poi un empodio in forma di lamina fogliare il quale presenta l'orlo marginale esterno fornito di numerosi peluzzi. L'estremiti posteriore dell'addome termina in un ovopositore costituito da 4 pezzi di cui i due estemi hanno l'orlo esterno dentato. I'ultimo steruite mostra un certo uumero di peli disposti simmetricamente (fig. 2, No. 11).

I'apertura anale è riparata da un'opercolo a forma trapezoidale munito di linguetta che arriva a mala pena o di poco o sopravanzare il margine posteriore dell'opercolo.

Nulla posso dire delle antenne con precisione perche i due eseniplari fenmine renuti in mio possesso le averano spezzate; dia resti rinvenuti mi sembra, però, che esse debbano essere conformi o poco dissimili da quelle delle altre specie.

Colore del corpo bruno.

Lunghezza del corpo più di un millimetro e mezzo.

Ala anteriore lunga $2250 \mu$.

“ " larga $1350 \mu$.

“ posteriore lunga $1920 \mu$.

“ " larga $1120 \mu$.

Zampe del I paio lunghe $1660 \mu$

Zampe del II paio lunghe $1750 \mu$

Zampa del III paio lunghe $1940 \mu$

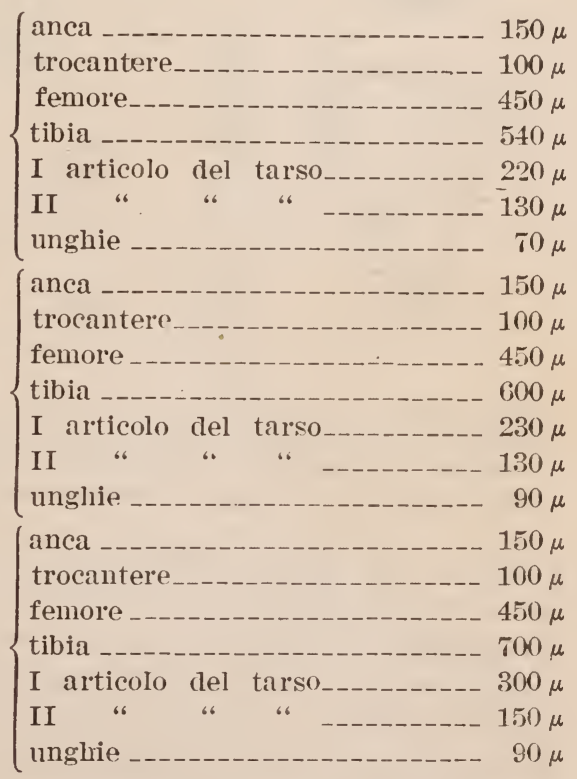

Habitat.-Raccolto nell'Argentina s' una pianta rimasta indeterminata.

L'insetto si rinviene fissato alla pagina superiore delle foglie, in colonie piu o meno numerose e la sua presenza è facilmente avvertibile causa l'ammasso dei lunghi filamenti cerosi dorsali che si intrecciano tra loro in tutte le direzioni formando cosi una specie di rete che probabilmente ha l'ufficio di proteggere gli insetti sottostanti dai nemici che li insidiano. 


\section{[Translation.]}

Lar'a (last stage).-The body is of decisively oval shape, with its anterior end slightly more acuminate than the posterior end. It is slightly convex, and along its margin it is surrounded by a sufficiently conspicuous stratum of a grayish-white waxy secretion, upon which rests the free end of the body of this insect. The body of this insect, along its free margin, is considerably inspissated, and it presents all around an uninterrupted and very narrow waxy fringe. On the dorsum this insect is partially covered by other waxy glomerules, and, furthermore, it has near the median line of the dorsum four very long and robust waxy filaments, such as can be seen in figure 1 [fig. 4].
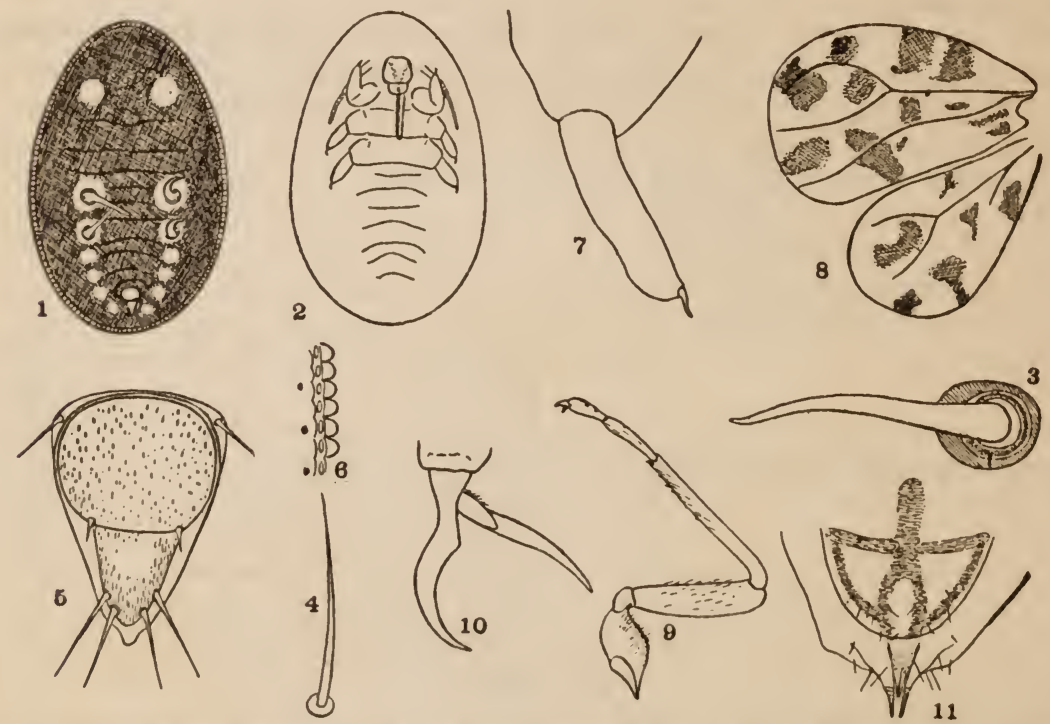

Fif. 4.-Leonardius lahillei: 1, Pupa case, dorsal view; 2, pupa case, ventral view; \$, anterior abdominal wax pore; 4, spine of pupa case; 5 , vasiform orifice of pupa case ; 6 , margin of puna case; 7 , leg of pupa; 8 , wings of adult; 9 , leg of adult; 10 , foot of adult, 11, female genitalia. (Redrawn from Leonardi.)

If the wax, which more or less invests the surface of the body of the insect, is removed its color is a ferruginous tint, darker along the marginal region, but less so toward the central region.

Moreover, it can be noted that the cephalic region of the body is not very distinct from the thorax. The thorax is more distinct from the abdomen, as the divisions between the thoracic segments, as compared with the abdominal segments, are less well marked.

The consistency of the dorsal tegument is not uniform, but, on the contrary, it shows zones, variable in dimension, in which the cuticle is very thin and transparent, and these zones correspond to groups of numerous and minute wax-producing glands whose presence causes these to assume the appearance of so many cribrate membranes. 
These zones we can segregate into two categories according to their dimensions and both, as regards the longitudinal diameter of the body, are arranged in perfect symmetry. The number of the major zones is seven pairs, arranged as follows: One pair situated in the cephalic region, one pair upon the second abdominal segment, another pair upon the fourth abdominal segment, and the others distributed per pair upon each of the succeeding rings. The second and the third pairs represent the most conspicuous zones and are characterized by presenting toward the center the mouth of a thick waxproducing gland provided with a robust chitinous conical process, more or less curved, upon which is placed the long waxy filament formerly described. The succeeding zones decrease in size successively as we proceed backward toward the posterior extremity.

The zones of the second series are, as has already-been stated, much less conspicuous and are distributed chiefly in the cephalic region, as can be observed by examining figure 2, No. 1 [fig. 4, 1].

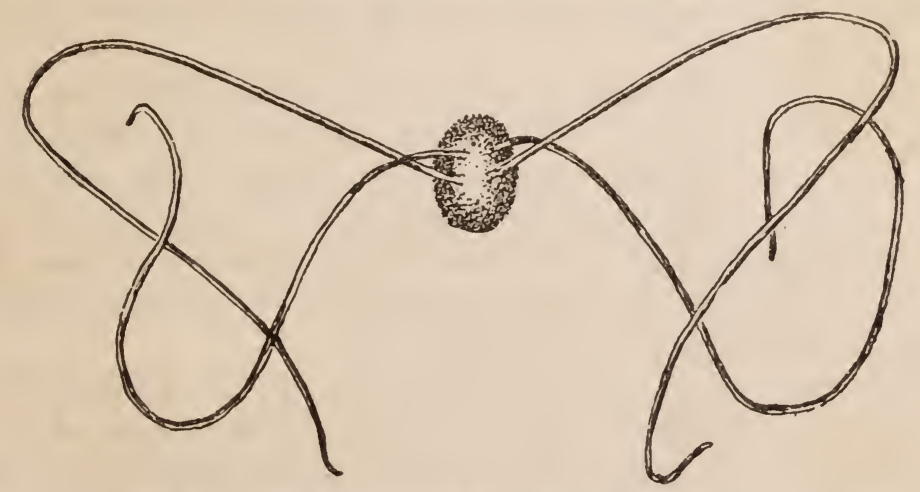

FIG. 5.-Leonardius lahillei, showing wax rods. (Redrawn from Leonardi.)

Parallel to the margin of the body, a short distance therefrom, runs all around a corona of short cilia which are symmetrically distributed. Another pair of cilia occupy also the thoracic segments, and another pair the cephalic region. The segments of the abdomen present a few mouths of minute wax-producing glands which are disposed in rows, sometimes single, sometimes double.

The anal aperture shows the operculum of rather large size, its width slightly exceeding its length, furnished with a conical lingula, obtuse at the apex, and furnished near the end laterally with two pairs of rather long bristles that are quite robust. Another pair of hairs that are less conspicuous is attached to the operculum, one at the right and the other at the left of the base of the lingula.

In regard to the venter, the insect presents no particular features except the rudimentary legs, which differ from those generally noted in the forms of the genus Aleyrodes at their extremity in not 
being provided, like the others, with a pulvillus, but only with a robust claw.

These characteristics, I suppose, are constant in the species which form the group Aleurodicus, because I find them also in the species which I shall describe after this, of which there is no doubt that it is an authentic Aleurodicus, as it presents very distinctly all the specific characteristics which serve to keep distinct from others the forms composing this group. This will be confirmed, I repeat, by other observations which will be able to furnish a perfect diagnostic characterization, notwithstanding the fact that by the absence of the adult forms the corresponding stage of the insect here described presents the other characteristics little conspicuous, so as to leave the author in doubt in regard to the place which ought to be assigned to the species.

Length of body $1.520 \mathrm{~mm}$.; width of body $1.000 \mathrm{~mm}$.; length of waxy filaments exceeds 1 centimeter; thickness of waxy filaments $0.080 \mathrm{~mm}$.; length of the conical process which supports the waxy filament $0.200 \mathrm{~mm}$.

Adult female.-'The general shape of the body conforms to that of the congeneric species. The wings are well developed, the anterior being much larger than the hind wings. They are covered with a very thin, whitish, waxy secretion.

'The forewings as well as the hind wings present numerous brown spots of varying size and with a contour more or less notched, as can be seen from figure 2, No. 8 [fig. 4, 8].

The legs are rather long, of medium thickness, subequal, the anterior pair being shorter. The variability of the length of the legs is due chiefly to the difference in length which exists between all the joints of the tibra and the tarsus, while the coxa, the trochanter, and the femur in all three pairs of legs are of equal length. All the joints of the legs are furnished with cilia which, on the whole, are short and slender. Those inserted on the coxa are more delicate but more numerous, while those inserted on the tibia are more robust and shorter in length. The tibia near its distal apex presents also two spur's of considerable size. The tarsus at its apex is provided with two long, robust claws, one of which at its internal margin is furnished with a tooth, the other being unarmed. Between the two claws there is an empodium in the shape of a foliate lamina in which the external marginal erlge is furnished with numerous fine hairs. The hind end of the abdomen terminates in an ovipositor consisting of four pieces the outside two of which present a dentate external margin. The last sternite shows a certain number of hairs systematically arranged. (Fig 2, No. 11 [fig. 4, 11]). 
The anal aperture is sheltered by an operculum of a trapezoidal shape provided with a lingula which hardly at all, or only a short distance, projects beyond the posterior margin of the operculum.

I can state nothing with precision about the antennæ because in the two female specimens which came into my possession they had been broken off; from the small remainder still intact it seems to me, however, that they are alike in conformation with, or only little dissimilar from, the antennæ of other species.

Color of body brown. Length of body a little more than $1.5 \mathrm{~mm}$; length of forewing $2.250 \mathrm{~mm}$.; width of forewing $1.350 \mathrm{~mm}$.; length of hind wing $1.920 \mathrm{~mm}$.; width of hind wing $1.120 \mathrm{~mm}$.

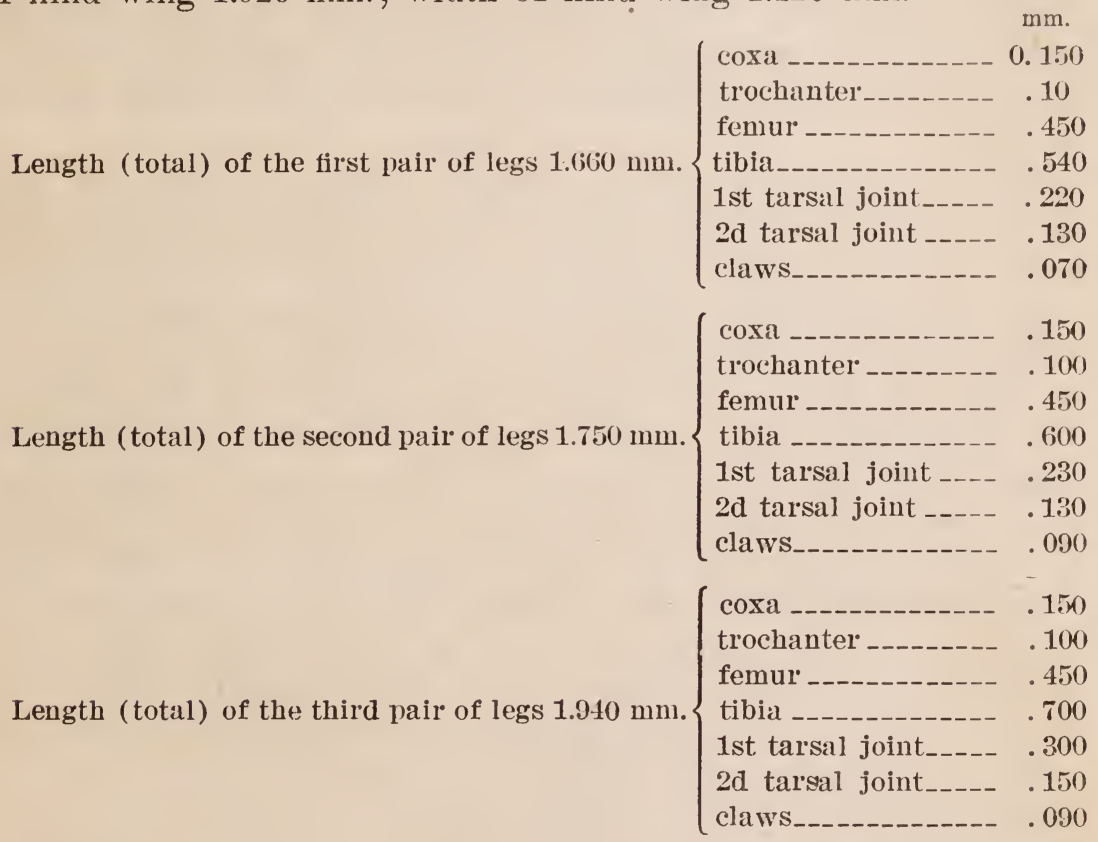

Habitat.-Collected in Argentina upon a plant not classified.

This insect is found attached to the upper surface of the leaves, in colonies more or less numerous, and its presence is readily ascertained because of the accumulation of the long dorsal waxy filaments which are interlaced amongst each other in all directions, thus forming a kind of net whose probable office is the protection of the insects from the enemies which infest it.

On January 18, 1912, Dr. C. W. Hooker sent from Mayaguez, Porto Rico, specimens of an aleyrodid taken on Phoradendron, parasitic on almond. These insects belong to the genus Leonardius herein described. They agree closely with the description of lahillei given by Leonardi. Slight differences are, however, noticeable. In 
our specimens, for example, the forewings are slightly shorter than the body, while in lahillei they are longer. The wings are also somewhat differentily marked, as will be seen from the illustrations, and the legs are relatively shorter in our specimens. We prefer, however, pending a careful comparison of the types, to leare the present form under the name of lahillei and give the following descriptive remarks.

\section{DESCRIPTIVE REMARKS.}

Egg (Pl. IX, fig. 1).-Length, $0.352 \mathrm{~mm}$. Shape elongate elliptical, surface unmarked, but numerous oily globules showing from within; stalk short, inserted slightly laterad of the base; color yellowish, with an orange-red area (part of the embryonic structure) at or near the base; red eyespots of the embryo often visible through the shell.

Pupa case (Pl. IX, fig. 2).-Length, $1.44 \mathrm{nmm}$; width, $0.88 \mathrm{~mm}$. Shape somewhat oval, broadest across the anterior part of the abdomen, narrower cephalad, dorsum slightly rounded, with the segments of the abdomen and the median longitudinal thoracic suture fairly distinct. There are seven pairs of large wax pores on the dorsum, one pair on the thorax, and six pairs on the abdomen. The thoracic pair and the four caudal abdominal pairs are of the agglomerate type (Pl. IX, fig. 4). They consist of a clear marginal area and a central area composed of numerous small papillx or rod-like pores, giving this area the appearance of a brush. The two anterior abdominal pairs (Pl. IX, fig. 5) have something of the nature of the true compound pores of Aleurodicus. There is a central process which is elongate and somewhat curved. Encircling this at the base is a series of spinnerets which are not elevated. The outer cup is shallow and outside it on the derm is a circular area of papillæ-like pores similar to those present in the agglomerate pore. 'This is bounded again by a clear area in which are a few scattered simple pores.

The vasiform orifice (PI. IX, fig. 3) is elongate cordate, with the anterior edge straight and the latero-caudad margin armed with teeth or folds. The caudal end is armed with a prominent projection. The operculum is almost rectangular, with rounded edges, somewhat broader than long and armed on the latero-caudad border with two spines. 'The lingula is conical, rather elongate, included, and armed with four spines. Both operculum and lingula are setose.

A pair of small setæ is situated just cephalad of the vasiform orifice, and within the margin of the case all around is a series of fine seta. The margin itself is entire but just within it (Pl. IX, fig. 6) are two or three rows of rounded papilla-like pores.

The color of the case under the microscope is yellow, shading into reddish brown near the margin. On the leaf it appears brown. 

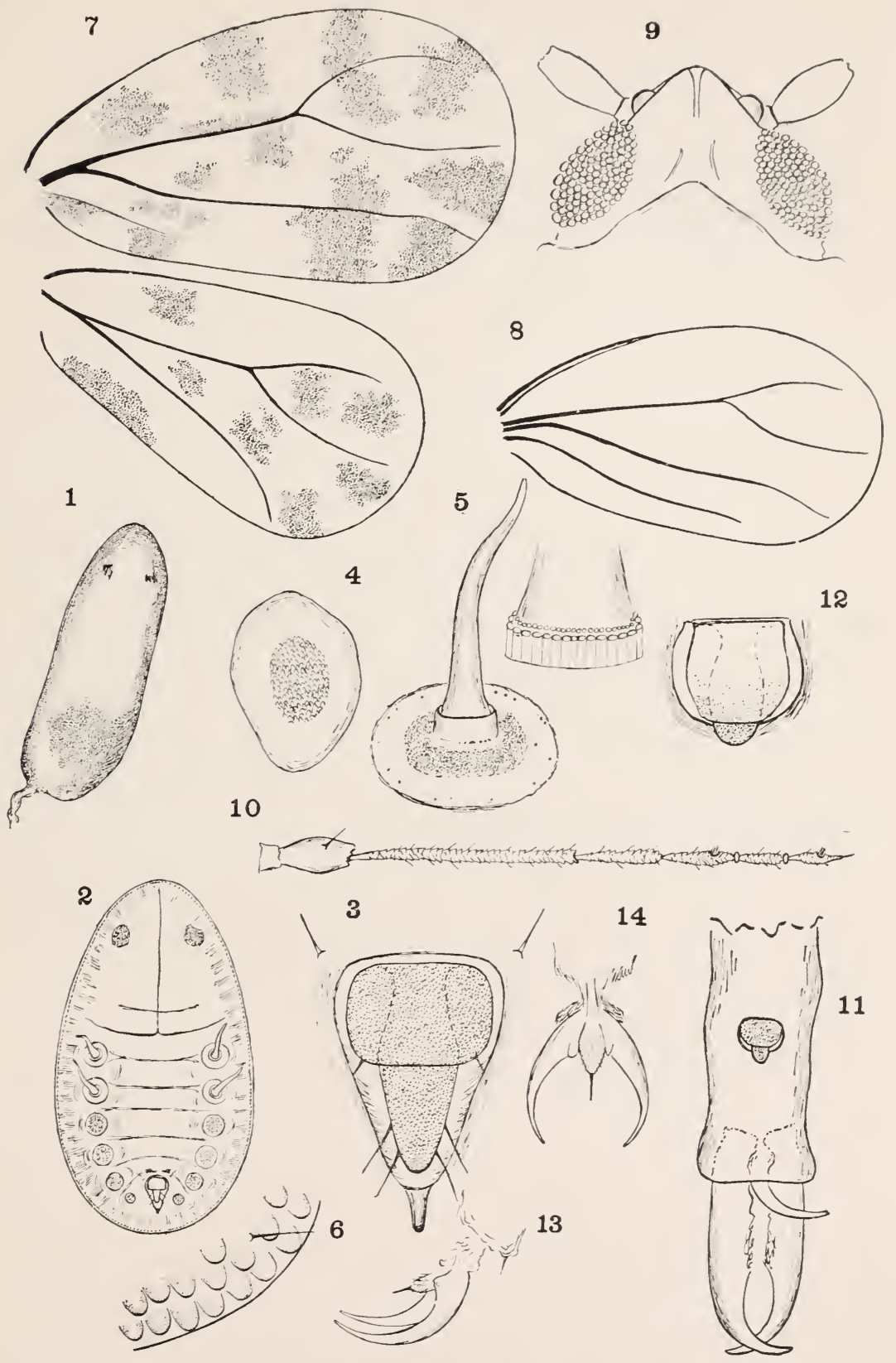

\section{LEONARDIUS LAHILLEI.}

Fig. 1.-Egg. Fig. 2.-Pupa case. Fig. 3.-Vasiform orifice of pupa case. Fig. 4.Agglomerate wax pore of pupa case. Fig. 5.-Compound wax pore of pupa case. Fig. 6.-Margin of pupa case. Fig. 7.-Wings of adult. Fig. 8.-Forewing of freshly emerged specimen, showing the cubitus. Fig. 9.-Vertex of adult. Fig. 10.-Antenna of adult. Fig. 11. Male genitalia. Fig. 12.- Vasiform orifice of adult male. Fig. 13.-Foot of adult. Fig. 14.- Same, showing claws spread. (Original.) 

There is a short, evenly trimmed marginal fringe of white wax all around and from the two anterior abdominal pairs of pores extremely long overhanging white waxen rods are secreted, one from each pore. These give the case the appearance of a phalangid with four white legs. The agglomerate pores secrete a small amount of granular wax.

Adult female.-Length, $2.24 \mathrm{~mm}$. Vertex (Pl. IX, fig. 9) produced, somewhat cone-shaped, with a median longitudinal furrow; ocelli large and distinct. Antennæ (Pl. IX, fig. 10) of seven segments: I, $0.064 \mathrm{~mm}$., cylindrical; II, $0.096 \mathrm{~mm}$., broad, pyriform; III, $0.208 \mathrm{~mm}$., narrow, cylindrical; IV, $0.128 \mathrm{~mm}$., cylindrical; V, $0.08 \mathrm{~mm}$., cylindrical, armed near its distal end with a fringed sensorium; VI, $0.016 \mathrm{~mm}$, cylindrical; VII, $0.064 \mathrm{~mm}$, armed at about its median part with a fringed sensorium and terminating in a bristle. Segments III-VII imbricated and armed with fine hairs. Between segments V and VI and VI and VII small ring-like segments can sometimes be observed.

Forewings $2 \mathrm{~mm}$. long, $1.2 \mathrm{~mm}$. wide, transparent, marked with dark brown, as shown in Plate IX, figure 7; hind wings $1.76 \mathrm{~mm}$. by $0.96 \mathrm{~mm}$., marked with brown, as in Pl. IX, figure 7. In the forewings of freshly emerged adults, before the markings are evident the cubitus can be distinctly seen (Pl. IX, fig. 8).

Fore-tibiæ $0.448 \mathrm{~mm}$.; fore-tarsi, proximal segment $0.192 \mathrm{~mm}$., distal $0.112 \mathrm{~mm}$; hind tibiæ $0.72 \mathrm{~mm}$. ; hind tarsus, proximal segment $0.288 \mathrm{~mm}$., distal $0.144 \mathrm{~mm}$; claws of foot (Pl. IX, fig. 14) well curved and acute, paronychium a narrow hairy structure armed with a central spine; ovipositor acute, armed with the usual spines. Color of head and thorax a reddish brown, shaded on the segments and appendages with dusky. Eyes brownish black, apparently not divided. Abdomen a brownish yellow, the red portions of the eggs within often showing as a red blotch.

Adult male.-In general appearance similar to the female. Forewings $1.84 \mathrm{~mm}$. by $0.9 \mathrm{~mm}$.; length from vertex to tips of claspers $2.64 \mathrm{~mm}$.; genital segment $0.512 \mathrm{~mm}$. long (Pl. IX, fig. 11) ; claspers $0.48 \mathrm{~mm}$., curved and acute; penis short and recurved.

\section{Genus ALEURODICUS Douglas.}

Aleurodicus Morgan, Ent. Mo. Mag. (2) vol. 3, p. 32 (1892).

Forms in this genus have radius ${ }_{1}$, radial sector, and the media present in the forewing, with sometimes an indication of the cubitus. The paronychium is represented by a large spine and the pupa case has large compound wax pores. A study of the forms indicates three subgenera.

Type, anonce Morgan. 


\section{Subgenera of Aleurodicus.}

I. Lingula of pupa case long, spatulate or conical, exserted; lingula of adult long, narrow, and included; compound pores as illustrated in Plate III, fig. 2.

A. Sides of pupa case flat, not deflexed under ventral surface; vertex of adult rounded_-_-_-_-_-_-_-_-_-_-_-_-_Subgen. Aleurodicus.

B. Sides of pupa case deflexed under ventral surface; vertex of adult slightly bilobed_-_-_-_-_-_-_-_-_-_-_-_Subgen. Lecanoideus.

II. Lingula of pupa case short, conical, usually included; lingula of adult broad, rounded, and exserted; compound wax pores of pupa case as illustrated in Plate XXVII, figure 3.-_-_-_-_Subgen. Metaleurodicus.

\section{Subgenus ALEURODICUS n. subgen.}

Fore wings with the reins as given for the genus. Vertex rounded, antennæ of seven segments, of which the third is the longest; claspers of male long and narrow; penis recurved, usually short; pupa case flat, with a number of large compound wax pores of the type illustrated in Plate III, figure 2, and sometimes a number of small reduced ones. Vasiform orifice with a long, setose, spatulate exserted lingula, which is armed with four long spines. Size usually large.

Type, anonce Morgan.

\section{Species of Subgenus Aleurodicus. ${ }^{a}$}

I. Pupa case with seven pairs of compound wax pores, one cephalic pair, and six abdominal pairs.

A. All seven pairs of pores equally developed; size of pupa case 1.33 to 1.5 $\mathrm{mm}$. long by 0.83 to 1 . min. wide; pores broad and shallow; margin of case with irregular rectangular areas and a submarginal row of strong hairs; outline of ('ase subelliptical to ovate; wings white, unmarked_-_-_-_-_-_-_-_-_destructor.

B. The two caudal pairs of wax pores and the cephalic pair more fully developed than the other four pairs, and with very long central chitinized processes; size of pupa case 1 by 0.53 mm., shape elliptical; edge of case with large crenulations; egg with the stalk nuch longer than the egg itself. Case raised on a vertical fringe of white wax and the dorsal surface covered with a plate of fused dirty white wax, through which the compound pores may be seen-_-_-_-__-_._-

C. The two caudal pairs of pores are much smaller than the other fire pair's.

1. Dorsal disk, as well as the submarginal area, covered with numerous simple pores; compound pores very large and well developed; margin of case entire, witl a row of stout hairs just within. Iingula long, with four very prominent hairs; operculum with

\footnotetext{
a It has not seemed wise to attempt to include in this key anone curtis and conspurcatus Enderdein. In the former specles the description is too vague, aud in the latter the immature stages are as yet unknown.
} 
two large hairs on caudal margin, one on either side. Size of pupa case 1.3 by $0.92 \mathrm{~mm}$. Shape broadly elliptical. Forewing of adult (female) $2.27 \mathrm{~mm}$. long, marked with dusky spots, six forming a ring around the margin of the wing, two being central. Segment $\mathrm{V}$ of antenne with a fringed sensorium and a stout spine near its distal end. Waxy secretion of pupa a series of fluted bands from simple wax pores, much longer than case is wide, and from the compound wax pores are produced very long, curling, brittle, glassy wax rods neglectus.

2. Dorsal disc without small simple pores, but the submarginal area all around with very many, forming a band.

a. Exposer portion of lingula of pupa case long and spatulate; operculum without a pair of spines on its caudal margin.

(1). Forewing of adult with one large central reddish brown marking over the radial fork and extending from the costal margin to or beyond the media. Length of forewing (female) $2.60 \mathrm{~mm}$.; genital segment of the male transversely wrinkled or striate. Pupa case with submarginal row of stout hairs; size 1.30 by $0.70 \mathrm{~mm}$. Shape elliptical. A prominent palisade of white wax raises the case from the leaf. Dorsum void of secretion, except the glassy wax rods from compound wax pores_____-_-_guppyii.

(2). Forewing of adult with four transverse gray bands, of which only the third and fourth are joined by a longitudinal band (Pl. XIV). Length of forewing (female) about $2.4 \mathrm{~mm}$. Pupa case ovoid or subelliptical, variable in size, from 1.15 to $1.3 \mathrm{~mm}$. long by 0.7 to $0.85 \mathrm{~mm}$. wide. Dorsum of case powdered with dirty white wax, and case raised by palisade of white wax. Lingula unusually large, dark brown in color dugesii.

b. Exposed portion of lingula of pupa case short and conical; caudal margin of operculum with a pair of spines.

(1). Pupa case broadly elliptical, with two large, dark, latero-dorsad areas extending the full length of the case. Margin entire, with a row of small simple pores some distance within it. All around on the submarginal area is a row of stout hairs. These occur a considerable distance mesad on the dorsum, some of them almost between the compound pores; spinnerets of the compound pores spread apart. Size of case 1.33 by 1.15 $\mathrm{mm}$

pulvinatus.

(2). Pupa case without dark latero-dorsad areas, but of uniform yellowish color; margin entire and just within it a row all around of large boat-shaped simple pores. A submarginal row of long hairs present inserted in about the same region. Spinnerets of compound pores compact. Size of case variable, ranging in length from 0.98 to $1.26 \mathrm{~mm}$, and in width from 0.98 to $0.7 \mathrm{~mm}$. Shape broadly oval, slightly narrower on cephalic end. Forewing of adult with two very faint dusky markings, one extending from the costal margin over the radial fork, the other at the apex of the wing. Length of forewing (female) $2.15 \mathrm{~mm}$.; claspers of male very long and narrow. Immature insects occurring along midrib of leaf and surrounded by a copious secretion of cottony-white wax._-_-_-_-_-_-_-_-_cocois. 
3. Submarginal area of pupa case without a band of small simple pores, but just within the margin all around, one row of disk-like simple pores. Forewing of adult with four more or less distinct dusky areas, one within the radial fork, one on either side of the union of radius ${ }_{1}$ and radial sector, and one on the proximal costal margin. Waxy secretion composed of distinct fine rods.

trinidadensis.

II. Pupa case with six pairs of compound wax pores, there being fire pairs of abdominal pores, of which the caudal pair is reduced.

A. Case with marginal row of large simple wax pores, bearing within several fine rods; margin itself entire and just within it a row of prominent hairs. Compound wax pores with the spinnerets much reduced and short; lingula spatulate, vers long and large, being about three times as long as the operculum, armed with four stout hairs. Size of case 1 by $0.84 \mathrm{~mm}$., shape broadly elliptical. Length of forewing (female) $2 \mathrm{~mm}$. Wings banded with duskr, as shown in Plate XXII, figure 5_-_-_-_-_-_-_ornatus.

B. Pupa case without a marginal row of large, simple wax pores, but the submarginal area corered with numerous vers small pores; margin entire; caudal margin of case with two large spines. Compound wax pores with the central process about the same height as the cup and the spinnerets not reduced and short, but about two-thirds the length of the central process. Lingula very long, spatulate, armed with four hairs. Caudal margin of operculum with two spines or hairs situated near the center.

jamaicensis.

III. Pupa case with fire pairs of compound wax pores, there being four abdominal and one cephalic pair, all of which are equally dereloped. Margin of case entire; just within it a row of large simple pores; smaller pores similar to these are scattered orer the entire dorsum; lingula very long, narrow, tapering, and armed with four hairs. Size of case 1.25 by $0.55 \mathrm{~mm}$.; shape elliptical; waxy secretion fairly abundant, semiflocculent or cottony, and more or less hiding the insects beneath_-_cocolobc.

\section{Aleurodicus anonæ Morgan.}

(Plate X, figs. 1-12.)

Aleurodicus anone Morgan, Ent. Mo. Mag. (2) rol. 3, p. 32 (1S92).

- Fig. 1. Larva of Aleurodicus anonœ, n. sp., surrounded with white secretion.

2. Mouth organs of same; $a$, mandibular; $b$, maxillary setæ; $c$, labium ; d, labrum.

3. Imago, same species, 우 $x 22$.

4. Genital organs of male; $a$, penis.

5. Posterior leg of imago.

6. Labium of same.

7. Genital organs of i imago; $a$, colon.

8. Larva, deprived of the white secretion, $\mathbf{x} 22$.

9. Leg of same.

10. Lateral funnel-shaped secroting gland of same.

11. Anus, colon, and fleum of same.

12. Marginal secretlng glands of same.

- Explanation of Plate I [Plate X], quoted from original description. 


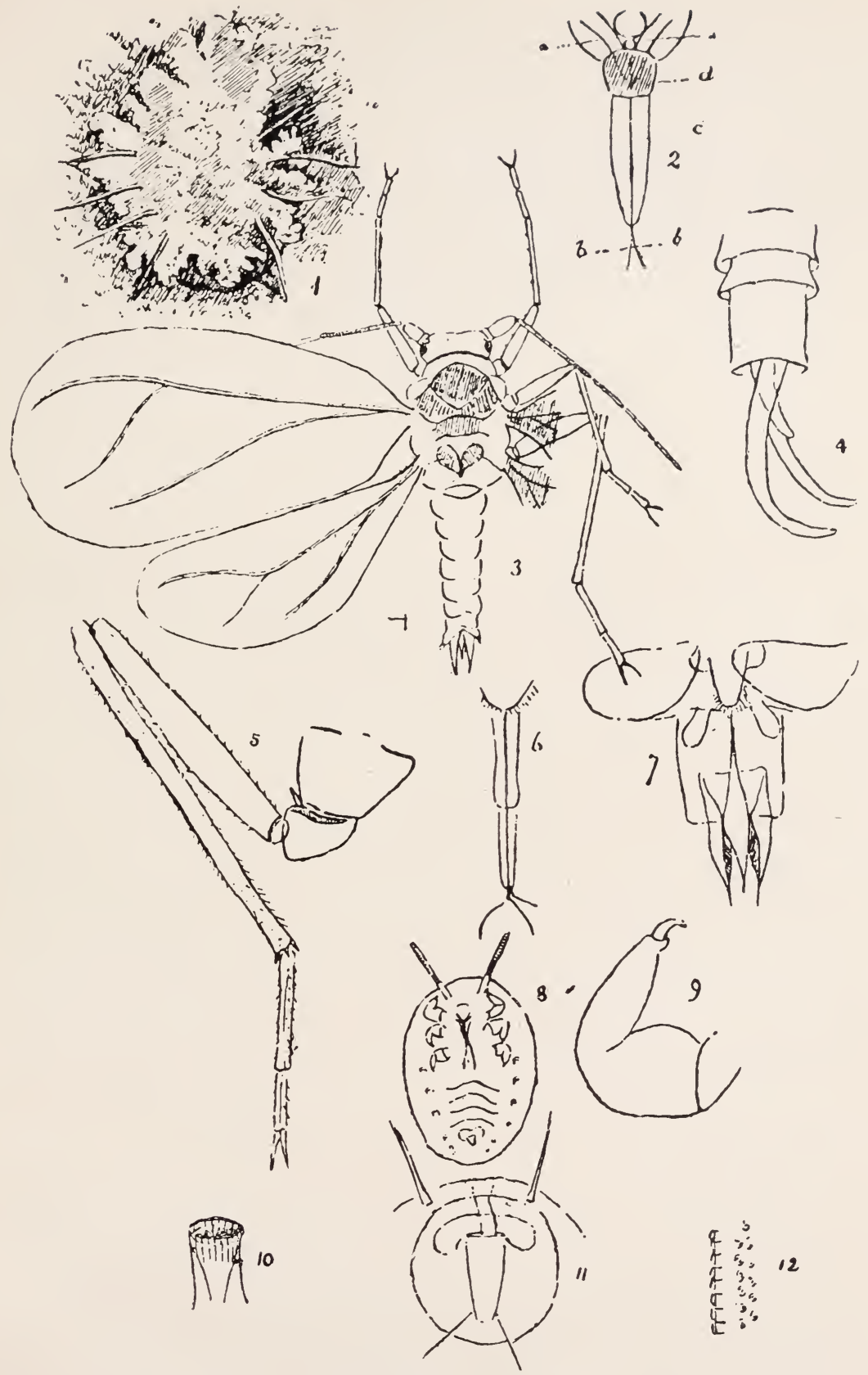

ALEURODICUS ANONF.

Fig. 1.-Larva surrounded with white secretion. Fig. 2.-Mouthparts of same: $a$, Mandibular; $b$, maxillary setæ; $c$, labium; $d$, labrum. Fig. 3.-Imago, same species, female, $\mathrm{x} 22$. Fig. 4.Genital organs of male. Fig. 5-Posterior lex of imago. Fig. 6.-Labium of same. Fig. 7Genital organs of female imago. Fig. 8-Larva, deprived of white secretion, x 22, Fig. 9.Leg of same. Fig. 10.-Lateral funnel-shaped secreting gland of same. Fig. 11.-Anus, colon, and ilium of same. Fig. 12.-Marginal secreting glands of same. (After Morgan.) 

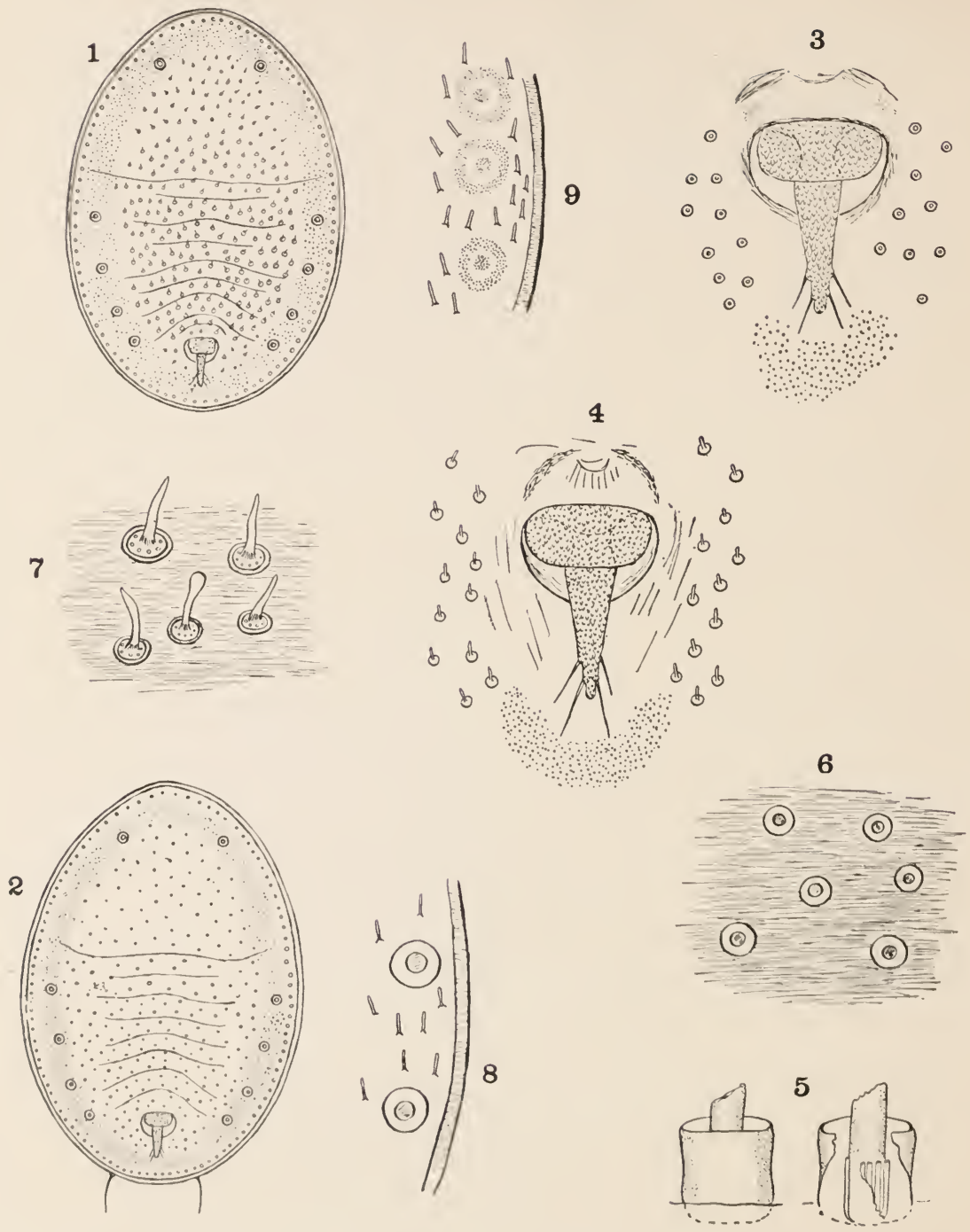

\section{ALEURODICUS COCCOLOBAE.}

Fig. 1. P'upa case parasitized. Fig. 2.- P'upa ease nonparasitized. Fig 3.-Vasiform orifiec of nomparasitized pupa case. Fig. 4. Vasiform orifice of parasitized pupa case. Fig. 5.-Compoumd wax pores of pupac ease. Fig. ti.-Dorsil pores of normal form. Fig. 7 . - Dorsil pores of parasitized forin. Jig. \$. - Margin of normal pupa case. Fig 9.-Margin of parasitized pupa case. (originill.) 
We have seen no example of this species. Material in the burcau collection supposed to be anona, on careful scrutiny, does not fairly conform to the original and rather indefinite description. So far as we are aware anonce has not been rediscovered since it was described. Following is the original description:

Larva. Oval, depressed, ochreous. Longest diameter $1.25 \mathrm{~mm}$. Antennæ apparently only 2-jointed, the second long and lateral, infundibuliform, compound spimnerets on each side, and posterior to these, two more simply constructed and smaller secret-glands on one side, also one on each side anterior to the first pair of legs. Labium one-jointed, prolonged. Labrum quadrilateral. Mandibular organs short, with the maxillary setæ long and fine (Pl. I [X], fig. 2.) Anus large, with long framework of colon easily distinguishable.

$\hat{o}$ and $q$ adult. Length $2.25 \mathrm{~mm}$. Antemmx long, 7 -jointed; basal joint short; second longer; third very long; fourth and fifth subequal; sixth and seventh shorter. Legs long; the posterior pair considerably longer than the others. Tarsus 2-jointed; in the posterior pair of legs the first joint of the tarsus is the longest, in the others equal. Two claws. Tibia and tarsus pinnate. One stout spine at junction of coxa with trochanter. Several small stout spines at junction of tibia and tarsus. Head inserted. Mesonotum chitinous, well developed. Scutellum, a pair of pyriform plates. Wings white, ample, broad; anterior incumbent, length $3 \mathrm{~mm}$. ; posterior, length $2 \mathrm{~mm}$. (PI. I [X]. fig. 3) ; strong central nervure bifurcated near the apex; branch nervure proceeding from the base of the central nervure. Genital organs of female bivalvular, and between the halves is situated the ovipositor (I'l. I [X], fig. 7). In the male the valvular organs are modified in the form of forceps, between which lies the penis (Pl. X, fig. 4). On the last segment of both sexes are two external processes.

Habitat: Anona muricata and Richardia pacifica, Demerara.

(Aleurodicus) Aleyrodes asarumis Shimer.

Aleyrodes asarumis Shimer, 'Trans. Amer. Ent. Soc., vol. 1, p. 281 (1867).

Aleurodicus asarumis Riley and Howard, Insect Life, vol. 5, p. 219 (1893). Aleyrodes actex Britton, Ent. News, vol. 16, p. 65, pl. 4 (1905).

This species was described as an Aleyrodes by Dr. Shimer. It was later transferred to Aleurodicus by Riley and Howard in Insect Life, Volume V, page 219, apparently without an examination of the form, and this placing has been followed by all subsequent writers. In Canada it occurs in large numbers on the underside of the leaves of the wild ginger and the cohosh, the plants from which Shimer described it. An examination of specimens, both of pupa and adults, collected by Prof. T. D. Jarvis, show the species to be an Aleyrodes and not an Aleurodicus. This we would expect, for all known forms of the genus Alcurodicus inhabit the warmer regions. Following Riley and Howard, Dr. Britton considered Shimer's species an Aleurodicus and redescribed and figured the form from the same plant under the name of Aleyrodes actece, in Entomological News, March 1905. His excellent description and figures can now be transferred to Shimer's species and finally settle the standing of asarumis. 
Aleurodicus coccolobæ n. sp.

(Plate XI, figs. 1-8.)

Collected on seagrape (Coccoloba uvifera), Progreso, Yucatan, by Samuel Henshaw, June 24, 1904, and forwarded to the Bureau of Entomology by Professor Cockerell. Only a fragment of leaf bearing a few pupæ is at hand, but the species is so distinct that its recognition from the pupal stage alone will be easy.

\section{DESCRIPTION.}

Pupa case.-Size $1.25 \mathrm{~mm}$. by $0.85 \mathrm{~mm}$.; elliptical in outline, moderately convex. As seen under hand lens the abdominal segments are quite distinct as transverse ridges. Color dull yellowish; parasitized specimens brownish black or plumbeous. There is a fairly abundant secretion of wax more or less hiding the insects beneath. The secretion consists of the usual long wax rods from the compound wax pores and a fairly copious secretion of semiflocculent or cottony wax from dorsum of case. There is a secretion all around of a narrow, short rim of fused glassy wax, seen best upon the removal of the more abundant flocculent secretion, and which largely persists on the leaf after removal of case (Pl. XI, fig. 2).

Under the microscope the case is pale yellow to almost colorless. Dorsum of case thickly covered with pores which, however, in the nonparasitized individuals, are made out with some difficulty. On the more central dorsal area, or dorsal disc, the pores are fairly large and scattered promiscuously. The smaller pores occur in a submarginal zone all around the case, and just within margin all around is a closely set row of pores somewhat larger than those on the dorsal disc (Pl. XI, fig. 2). The location of these pores is very evident in parasitized pupæ (Pl. XI, fig. 1), which condition apparently produces rather important structural changes in the pores. In the case of the pores on the dorsal disc there is produced from center of pore a short papilla or peg, acute, rounded, or swollen at tip. From each of the smaller pores forming the submarginal zone is produced a short finger-like process. The pores just within margin of case all around show a group of small dark granules surrounded by many minute granulations. In the single parasitized pupa of jamaicensis, constituting the type of this species, are to be noted the same minute finger-like processes from the submarginal zone of pores, but the dorsal pores above mentioned appear to be wanting in jamaicensis, and in comparing the lingulæ the species are readily seen to be different.

Margin and dorsum of case apparently without spines, except a pair on caudal end of case. 
On each side of the abdominal region are four compound wax pores, and there is a pair present on the cephalic end of case ( $P$ l. XI, fig. 5). There are no reduced compound pores on caudal end of case as in many species.

Vasiform orifice broadly cordate. Operculum subrectangular and about twice as broad as long, the ends rounded. Lingula long, exserted, tapering regularly from base to narrow tip. Two pairs of spines arise near distal end of lingula (Pl. XI, fig. 3).

Adult.-Unknown.

Type.-No. 14765 , U. S. National Museum. Described from a few pupæ on leaf, and three parasitized specimens in balsam mount.

\section{Aleurodicus cocois (Curtis).}

(Pl. XII, figs. 1-15; Pl. XIV, fig. 1; text figs. 6-9.)

Aleurodes cocois Curtis, Gardeners' Chronicle, 1846, p. 284.

Aleurodicus iridescens Cockerell, Psyche. vol. 8, p. 226 (1898).

This species was described by Curtis from specimens on coconut and was transferred to Aleurodicus by Morgan (1. c.). Later it was fully described by Riley and Howard in Insect Life, Volume V, page 314 , and later Cockerell described what appears to be the same insect as Aleurodicus iridescens in Psyche, June, 1898. These three descriptions and the figures accompanying them are herewith reproduced.

\section{ORIGINAL DESCRIPTION.}

[Fig. $6(1,2,3,4,5)$.

Aleyrodes cocois (the Cocoa-nut Aleyrodes). There is a little white mealy fly which sometimes infests the cabbages, and an allied species has been sent from the West Indies, which differs from it in its structure and economy. We are indebted to Sir Robert Schomburgk for specimens of this curious and destructive insect, the publication of whose history will be acceptable to the cultivator of exotics, and it is to be hoped that it may lead to the discovery of some mode of extirpating it. Sir Robert says, "On my arrival in Barbadoes, I was forcibly struck with the withered appearance of the Cocoa-nut trees. and I hare since been told that a disease is prevailing amongst them which threatens to destroy all the Cocoa-nut trees in the island. This remarkable disease showed itself in the island after the fatal hurricane in 1831, and there are only a few trees which are not afflicted by it. It is no doubt to be ascribed to an insect allied to Aleyrodes. A great many of the plantations of Cocoa-nut trees which formerly vielded an income of $200 \mathfrak{f}$ or $300 £$ per annum have not a single tree which bears fruit. The lower leaves die first and fall off, the flowers follow, or if nuts should have been formed they dwindle away and do not arrive at maturity; ultimately the budding leaves are attacked, and the crown drops off, leaving the withered trunk.

"It is considered that this disease has been introduced since the hurricane, from some of the neighbouring islands, when it became necessary to replace a number of Cocoa-nut trees which had been destroyed; but some pretend that it bas been occasioned by the introduction of guano. Smoking, \&c., has been of 
no avail, and as the insect most sagaciously places itself under the leaflet, where it is protected against the weather, the heariest rain does not affect it. It has been advised to root up all Cocon-nut trees in the island. and after the lapse of a year, when it is thought the insect may be destroyed, to replant the plantations from seeds imported from an island where the insect does not exist.

" On carefully examining the leares of the Cocoa-nut, it is evident there are two distinct insects upon the under surface, an Aleyrodes and a Coccus. They adhere to the under side of the leaf, and are surrounded by a whitish cottony or resinous powder; both sexes of the Aleyrodes at rest and with their wings closed are exhibited, of their natural size, on a portion of the leaf (fig. 1) [fig. 6. 1], and also some oval animals producing the white powder in abundance from the margins of their sides, and these I suppose are the larva state of the Aleyrodes. There are also numbers of white linear cases, as shown at fig. 5 [fig. 6, 5], which I conceive to be the pupæ of a male Coccus; indeed I found one of the perfect insects sticking to the surface. At fig. 2 [fig. 6. 2] I have represented the under side of one of the larvæ; it is oval, concave, ochreous, and shining, with six minute legs and rentral wings, like a female Coccus; but I could not detect any proboscis or antenur. I must, howerer, observe that the objects had all suffered from extreme pressure and great heat, and it is not

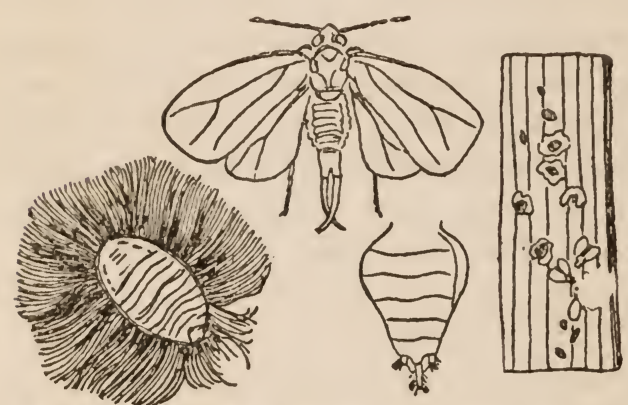

FIG. 6.-Aleurodicus cocois: 1, Insects on leaf; 2, pupa case; 3, adult; 4, abdomen. (From Curtis.) unusual for the proboscis to be broken off in remoring such animals from the surface on which they are feeding."

The winged specimens are larger than any of our British Aleyrodes, and from the neuration of the wings being different, as well as from the remarkable anal forceps of the male, this insect might with great propriety be separated from the genus Aleyrodes. A. cocois is bright ochreous, the head is rounded, the eyes are black, oval, and notched on the inside, and I think I could discern two minute ocelli on on the inner margins; the antennæe are as long as the thorax, slender, and apparently seven-jointed, basal joint stoutish; second, the longest. The rostrum is stout and moderately long; the thorax is nearly orbicular, the scutel distinct, the abdomen short and oval in the male, with the last segment long, narrowed, and cylindrical, producing two long incurved claws, forming a pair of forceps (fig. 3) [fig. 6, 3]; wings apparently horizontal in repose, clothed with white scales or hairs, giving them a powdered appearance; superior ample, subelliptical, with a strong costal nervure, and a furcate one with a longitudinal nervure beneath it, issuing from near the base; inferior wings smaller, with a single forked nervure. Six legs slender, hinder long but simple; the tarsi biarticulate, basal joint the longest, the second terminated by two slender claws. Female similar, but the abdomen is ovate-conic, the apex terminated by a very acute transparent valve with a small oval hairy lobe on each side (fig. 4). [fig. 6, 4].

As insects will remain in an embryo state for long periods, every vestige of the infested trees should be burnt as soon as they are taken down, and the most diligent search must be made after the Aleyrodes upon plants of the same natural order as the Cocoa-nut, to ascertain if there are not colonies established elsewhere. There is the larva of a little beetle, called scymnus, 
which destroys the European Aleyrodes, and it is remarkable that no parasitic insect should have appeared to check the increase of the Cocoa-nut species, but this may arise from the disease having been imported without its usual attendant antidote. Fumigating with sulphur would arrest the plague, if it could be applied; but then it ought to be done simultaneously to be effective, or else at a season when the insects are inactive--Ruricola.

\section{RILEY'S AND HOWARD'S DESCRIPTION.}

(Figs. 7, 8, 9.)

The egg (fig. 41, a) [fig. 8, a].-We know the egg only from specimens taken from the bodies of gravid females. Length, $0.29 \mathrm{~mm}$; greatest width, $0.11 \mathrm{~mm}$.; length of pedicel, $0.064 \mathrm{~mm}$. From these measurements it will be seen that the

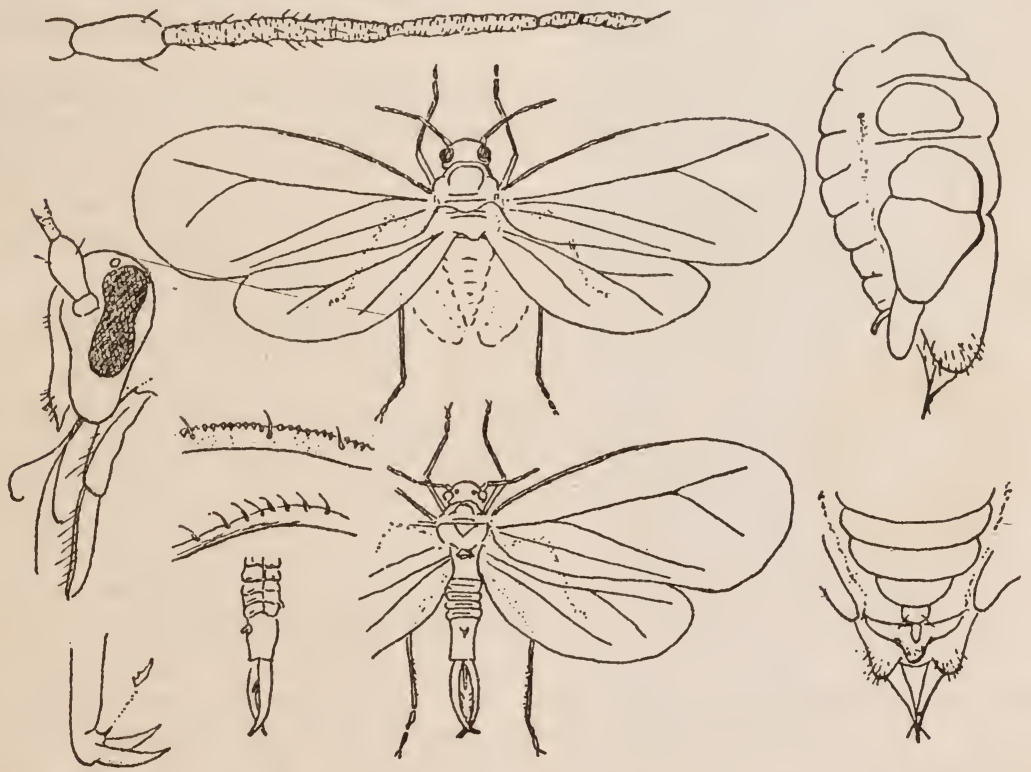

FIG. 7.-Aleurodicus cocois: $a$, Adult female; $b$, side view of abdomen; $c$, dorsal view of abdomen; $d$, antenna ; $e$, head from side; $f$, costa of forewing; $g$, costa of hind wing : $h$, tarsus ; $i$, pulvillus; $k$, adult male; $l$, claspers. (From Riley and Howard.)

egg is broader in proportion to its length than that of Aleyrodes citri. The pedicel, instead of arising from the base of the egg, has its origin on the side, somewhat above the base, as shown at fig. 41, $a$. No sculpturing is observable.

Neuly-hatched larva, first stage (fig. 41, b) [fig. 8, b].-What we assume from its size to be the first stage has been sparingly found in a more or less dried up condition upon the leaves of guava received. It is $0.41 \mathrm{~mm}$. long and $0.19 \mathrm{~mm}$. wide, regularly elliptical, flattened and smooth. Twelve hairs of medium length protrude from each side. Antennæ short, apparently five-jointed, joints subequal. Rostrum one-jointed, arising from a point half way between the middle of the body and the anterior extremity. The dorsal anal pore is distinct, and the long conical organ protrudes.

Larva, intermediate stage (fig. $41, d, g$ ) [fig. $8, d, g] .-\mathrm{A}$ stage intermediate between the newly hatched larva and that which seems full grown has been 
found and carefully studied. It is flattened, of short, oval form, $1.02 \mathrm{~mm}$. long and $0.8 t \mathrm{~mm}$. wide. The legs are plain and are short, stout, and apparently three-jointed. The basal joint is very stout, nearly as broad as long; the second joint is slender, about twice as long as broad; the third joint is very short, and bears a single, stout, curred hook. The rostrum is distinct, one jointed, and three filaments protrude. Each abdominal segment bears laterally a large, complicated pore, from which protrudes a glassy filament, short in this stage, but very long in the following. A smaller pore is situated just laterad of the base of the antenna and those on the anal and pre-anal segments are smaller than those on the others. Antennæ six-jointed. Joint 1 short, stout; joints 2 and 3 long, sub-equal in length, and each five times as long as 1 ; joint 4 one-half as long as 2 or 3 ; joint 5 one-half as long as 4 , sharply pointed at tip. Dorso-anal pore large, distinct; protrusile organ conical in shape, supported by a tri-lobed chitinous framework. Entire dorsal surface of body finely granulate, the ventral surface granulate laterally to the large pores. Each ventralabdominal segment bears a transverse row of eight small secretory pores, each of which seems to be tri-cellular.

Adult larva (fig. 40) [fig. 9].-Closely resembles the preceding, except that it is much more convex, anci has very. long glassy filaments and an abundant

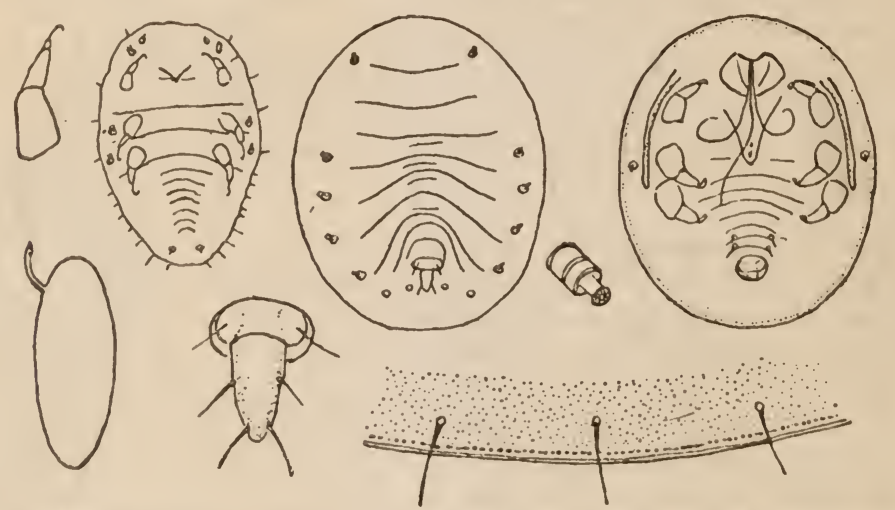

Fig. 8.-Aleurodicus cocois: $a$, Egg; $b$, first larva; $c$, leg of same; $d$, intermediate larva, dorsal view; $e$, protrusile organ of same; $f$, secretory pore of same; $g$, intermediate larva, ventral view; $h$, margin of body of same. (From Riley and Howard.)

secretion of white wax. Abdominal segments very distinct, arched anterodorsally, with a medium longitudinal ridge. The skin of this larva splits transverso-dorsally along the hinder edge of the thorax, and from the middle of this slit medially and longitudinally to the cephalic end of the body. From this double slit the pupa presumably emerges.

Adult female (fig. 39, a) [fig. 7,a].-Length, $2.1 \mathrm{~mm}$; expanse, $4.1 \mathrm{~mm}$. Color dull honey-yellow; eyes darker; abdomen, when swollen with eggs, much lighter and bordered with abundant waxy secretions. Antemix six-jointed. Basal joint short, stout; joint 2 (scape) twice as long, equal to it in width; flagellum rugoso-annulate; joint 3 longest, more than twice as long as 1 and 2 together. and equal in length to 4,5 , and 6 together. In driml specimens it becomes espeeially constricted at two points; joint 4 rather more than half as long as 3 ; joint 5 less than half as long as 4 ; join 6 equal in length to 5 . Joint 6 with a bistle at tip, the other joints with sparse, short bristles. Ifead conical when seen from above, the rostrum plainly 2-jointed, but perhaps with a basal joint; the apical joint acute, nearly as long as the preceling joint. Eyes pyriform, large. 
Two ocelli, large and conspicuous. Wings large, subopaque, median vein divided at two-thirds wing length. Costa of fore-wing finely crenulate to tip, furnished with sparse bristles arising below edge of wing. Costa of hind wing with 8 or 9 rather long bristles or hairs near base. Legs slender, moderately long, hind tibia with an internal row of bristles, tarsi 2-jointed, two large tarsal hooks, with a median basal hook-like appendage much smaller than the lateral hooks. Abdomen with six plain tergites, but five visible urites. Sixth tergite bearing a pronounced median curved papilla; ovipositor acute.

Adult male (fig. $39, k$ ) [fig. $7, k$ ]. - Resembles the female except in being more slender and longer by virtue of the two large forficular claspers, nearly as long as the entire abdomen and which gave the average specimen a total length of 2.8 nim., as against $2.1 \mathrm{~mm}$. for the female. Between the two claspers is a short curved style rather more than onethird the length of the claspers. Sixth tergite bears a median papilla and the fourth urite a similar one. Color of abdomen much darker than in female, particularly at hind border of segments; claspers still darker.

\section{COCKERELL'S DESCRIPTION OF ALEU- RODICUS IRIDESCENS.}

Agrees with A. asarumis in having some blackish coloration at the forking of the wing-vein, but differs in having the body and legs a deep chrome yellow, and the eyes not divided. Length of anterior wing $2 \mathrm{~mm}$; wings noticeably iridescent; a blackish line on the costa. Pupx along the mid-rib of the leaf, as in Aleurodicus pulvinala (Maskell as Aleurodes), surrounded by abundant cottony secretion. Pupæ dark grey or plumbeous, varying to brownish, structural characters as usual in the genus. Vasiform orifice semicircular; operculum very broad, broadly truncated at end. Four large round orifices on each side of the abdomen, some distance from the margin, but not nearly so large as Maskell figures for pulvinata; four very much

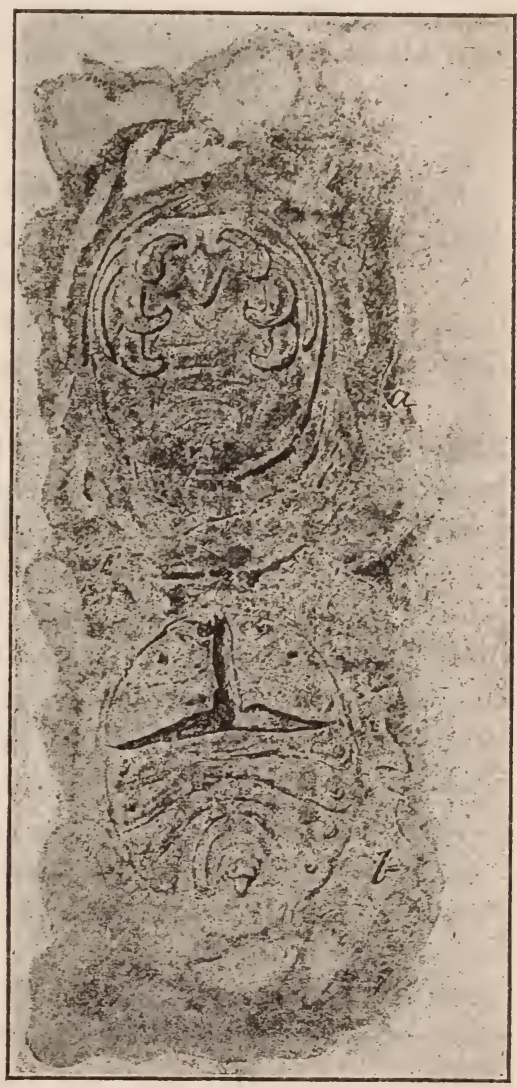

FIG. 9.-Aleurodicus cocois: a, Skin of full-grown larva from below; $b$, skin of full-grown larva from above. (From Riley and Howard.) smaller orifices in the caudal region, laterad of the rasiform orifice, the two hindmost nearer to each other than are the anterior ones; two of the large orifices at the cephalic end, and also four small ones as in pulvinata, but they are very minute.

Hab.-Ocean beach between El Faro and San Pedro, Tabasco, Mex., June 12 , 1897 , on "Jicaco," a bush with large leares growing on the sand flats (Townsend) Div. Ent. 7824.

In the original description there is little given by means of which this species could be distinguished from others in the same genus. 
Realizing this, Riley and Howard made a careful description of the form. The material upon which their descriptions were based is preserved in the bureau collection, and the following includes a study of this same material. Unfortunately, a slight marking on the forewings of the species was not considered of importance by Riley and Howard, as it was no doubt overlooked by Curtis. This oversight has led Cockerell into the error of redescribing the form as iridescens. Now, however, that Riley and Howard's specimens, Cockerell's types, and many other examples are at hand for study, there is little doubt that all these forms are the same species.

\section{DESCRIPTIVE REMARKS.}

Pupa case.-The pupa cases representing the Riley and Howard material and those composing Cockerell's types, as well as numerous others, are identical in structure as follows: The case (Pl. XII, fig. 2) is surrounded by a row of bristle-like hairs inserted on the dorsum just within the margin. There are usually 13 of these to a side. One pair of long, prominent caudal hairs is also present. Margin entire, and within it all around (Pl. XII, fig. 7) is a row of large, simple, boat-shaped pores and the submarginal area is covered with very many minute, simple ones. Along the median thoracic region there are four pairs of small tubercled setæ and on the cephalolateral portion a pair of large compound pores of the type illustrated in Plate XII, figure 6. The abdominal region has along each side four large compound pores similar to the thoracic pair, and on either side of the vasiform orifice are two reduced ones. The vasiform orifice is nearly cordate and just cephalad of it is a pair of setx, one on each side. The operculum is subelliptical, broader than long, and armed caudad with two prominent bristles. The lingula is conical, exserted, and possesses two pairs of bristles. Both operculum and lingula are minutely setose.

On the underside (Pl. XII, fig. 3) the mouthparts, legs, and antennæ are distinct. The trophic tubercle is large, the labium quite distinct, while the setæ are usually carried in the form of a loop. The antennx are of two segments, $0.33 \mathrm{~mm}$. long, and the proximal segment is short, subcylindrical, and unarmed. The distal one is much longer and annulated. At its distal end a short unguis is present and at the base of this a fringed sensorium. The legs are short, thick, of two segments, and armed with a solitary curved claw (Pl. XII, fig. 4).

There is considerable variation in the size of the pupa cases, and on this ground it might be possible to separate iridescens from cocois. Since, however, we have considerable difference in the cases of the latter species, depending upon locality and food plants, it seemśs hardly justifiable to select the larger specimens and call them a differ- 

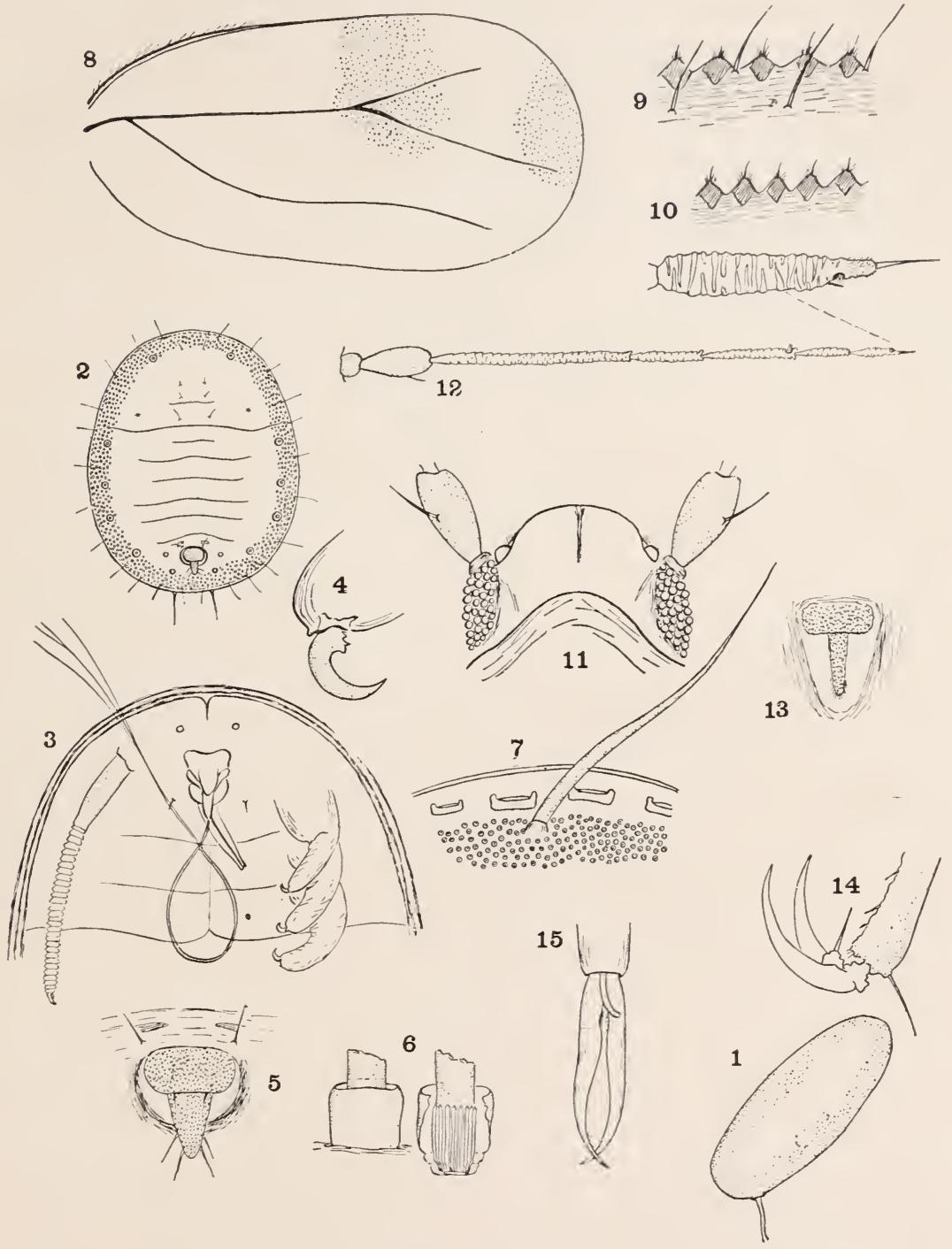

ALEURODICUS COCOIS.

Fig. 1.-Egg. Fig. 2.-Pupa case. Fig. 3.-Portion of venter of pupa case. Fig. 4.-Claw of pupa. Fig. 5-Vasiform orifice of pupa case. Fig. 6.-Compound wax pore of pupa case. Fig. 7.-Margin of pupa case, showing boat-shaped pores. Fig. 8.-Forewing of adult. Fig. 9.-Proximal costal margin of forewing. Fig. 10.-Distal costal margin of same. Fig. 11. - Head of adult. Fig. 12.-Antenna of adult. Fig. 13.- Vasiform orifice of adult. Fig. 14.-Foot of adult. Fig. 15.-Male genitalia. (Original.) 

ent species. On the other hand, we have specimens from the Canal Zone in which the pupa cases are of quite a different form from the usual type, being broader. There appear three varieties, one with a large and comparatively elongate pupa, one with a small elongate pupa, and one with a broad pupa. In these there appear no structural differences. The larger material, that which we might call the iridescens material, has an average of $1.22 \mathrm{~mm}$. by $0.92 \mathrm{~mm}$., the smaller material an average of $1.06 \mathrm{~mm}$. by $0.75 \mathrm{~mm}$., while the Canal Zone material, lot No. 6768, has an average of $1 \mathrm{~mm}$. by $0.89 \mathrm{~mm}$. The largest specimen found in any material was $1.26 \mathrm{~mm}$. by $0.98 \mathrm{~mm}$. and the smallest $0.98 \mathrm{~mm}$. by $0.7 \mathrm{~mm}$.

The arrangement of the pupæ upon the leaf in reference to the median vein and the waxy secretion developed about them is similar in Cockerell's type of iridescens and in cocois (Pl. XIV, fig. 1). The difference in host would easily account for the slight difference seen. Adults.- Some variation is shown in the adults, first, as to size and, secondly, as to wing marking. The type of Cockerell's iridescens in the U. S. National Museum collection is a small male and will be discussed under that sex. The vertex (Pl. XII, fig. 11) is rounded and the antennæ (Pl. XII, fig. 12) are of seven segments, not six, as stated by Riley and Howard. Segment III is much the longer; II, IV, and V nearly equal in length, while VI and VII are somewhat shorter. All the segments are imbricated, and V and VII are armed with fringed sensoria. The paronychium of the foot is the usual spine, and the basal segment of the tarsus is nearly twice as long as the distal one. The forewings are armed on the costal margin (Pl. XII, fig. 9) with conical hairy projections and two alternate rows of large bristle-like hairs. The remainder of the margin (Pl. XII, fig. 10) lacks these hairs. The wings are marked with two dusky patches, one from the costal margin crossing the radial fork and the other at the distal extremity of the wing. In most forms these patches, especially the distal one, are very indistinct, but many degrees of intensity of shading occur, and in specimens from Progreso, Yucatan, lot No. 3286, the clouding is quite marked. Some dry specimens in which we were not able to distinguish any marking showed it quite plainly when balsam mounts were made.

The female genitalia are of the ordinary Aleurodicus type. The forewing is $2.15 \mathrm{~mm}$. by $1.15 \mathrm{~mm}$, the hind tibix $0.77 \mathrm{~mm}$., and the tarsi together $0.307 \mathrm{~mm}$.

The males show a great range in size. This is shown in a comparative measurement of parts. The type of iridescens has claspers 0.4 $\mathrm{mm}$. long, and the width of the genital segment is $0.22 \mathrm{~mm}$. In material of cocois, from different regions and hosts, a range from 0.4 $\mathrm{mm}$. to $0.92 \mathrm{~mm}$. is met with in the claspers, depending upon the size of the individual. The average seems to be nearly $0.8 \mathrm{~mm}$. In 
the wings a similar variation is met with. In endearoring to determine whether Cockerell's type was different from the forms of cocois, a large series of male wings was measured. Some were found smaller than Cockerell's iridescens and some larger, while in every case the relative position and lengths of the veins were practically identical. The average length of the forewing is $2 \mathrm{~mm}$. and its width $0.89 \mathrm{~mm}$., and the hind tibiæ average $0.7 \mathrm{~mm}$.

The species is represented from the following localities and upon the following hosts:

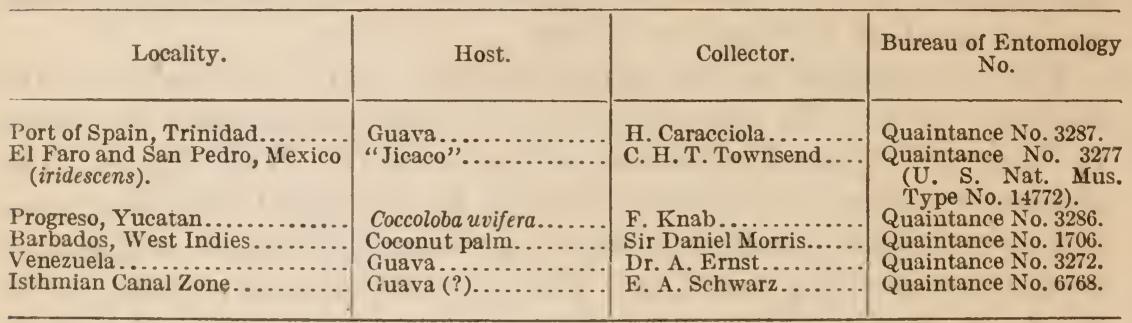

Aleurodicus conspurcatus Enderlein.

(Fig. 10.)

Aleurodicus conspurcatus Enderlein, Stett. Ent. Zeit., 1909, p. 282.

The following is Enderlein's diagnosis of this species. It is unknown to us in nature, but evidently shows a relation to species more generalized than those of this genus by the retention of the cubitus (Enderlein's analis). When all the stages are known, it may be necessary to remove it to one of the earlier genera.

\section{ORIGINAL DESCRIPTION.}

Hell bräunlich gelb, Augen grau; Beine blass ockergelblich; Spitzenhälfte des Abdomen grau, Seiten der Basalhälfte ockergelb. Abdomen selı schmal und schlank ( $\hat{o})$, letztes Glied etwi $2 \frac{1}{2}$ mal so lang wie breit, vorletztes etwa so lang wie breit, beim $q$ gedrungen und kurz. Endzange des $\hat{o}$ sehr lang und schlank, und erst am Ende nach innen umgebogen, etwa $\frac{3}{4}$ des letzten Segmentes; l'enis in Form eines stibchenförmigen Auhangs am Grunde der Zangen und zwischen ihnen, sehr kurz (nur etwa $\frac{1}{4}$ der Zangenlänge), dïnn und senkrecht aufgerichtet. Stirmand von oben gesehen eine etwas abgerundete rechtwinklige Ecke bildend.

Flïgel hyalin, weiss bestiubt; Vorler- und Hinterfligel mit kleinen, unregelmässig geformten, braunen, spirilich rerteilten Flecken. Die Costa im Vorderfligel fein, aber deutlich; der Radialramus $(r)$ in beiden Flïgeh in der Mitte stark nach dem Aussenrande zu umgebogen. Der Cubitus endet in beiden Fluigeln an der Hinterecke des Aussenrandes; im forderfligel ist er nahe der Basis stark, nabe dem Ende schwach wellig gebuchtet. Analis im Vorderfligel fein aber deutllch bis zur Mindung in der Mitte des Hinterrandes zu verfolgen; in Hintertligel fehlt sie. In beiden Fligeln erreichen Media und $r u$ nicht ganz den Flïgelrand, der Radialramus endet ziemlich weit rom Fligelrand entferut. 
Körperlänge ô $2.5 \mathrm{~mm}$., $+2 \mathrm{~mm}$.; Abdominallänge ô $1.75 \mathrm{~mm}$., \& $1 \mathrm{~mm}$.; Vorderflügellauge $\hat{\delta} \quad 2.5 \mathrm{~mm}$., $\uparrow 3 \mathrm{~mm}$., Hinterflügellange $\hat{o} \quad 2.1 \mathrm{~mm}$., $\uparrow 2.75$ $\mathrm{mm}$. Grösste Vorderflügelbreite $\hat{\delta} 1.5 \mathrm{~mm}$, \& $2 \mathrm{~mm}$. Grösste Hinterflügelbreite ô $1.15 \mathrm{~mm}$., 우 $1.5 \mathrm{~mm}$.

Süd-Brasilien. Santa Catharina. 13 Exemplare (3ô und 10 \&). Gesammelt von Lüderwaldt.

Typen im Stettiner Zoologischen Museum.

\section{[Translation.]}

Clear brownish yellow. Compound eyes gray. Legs pale ochreyellow, lower half of abdomen gray, the lateral part of the basal
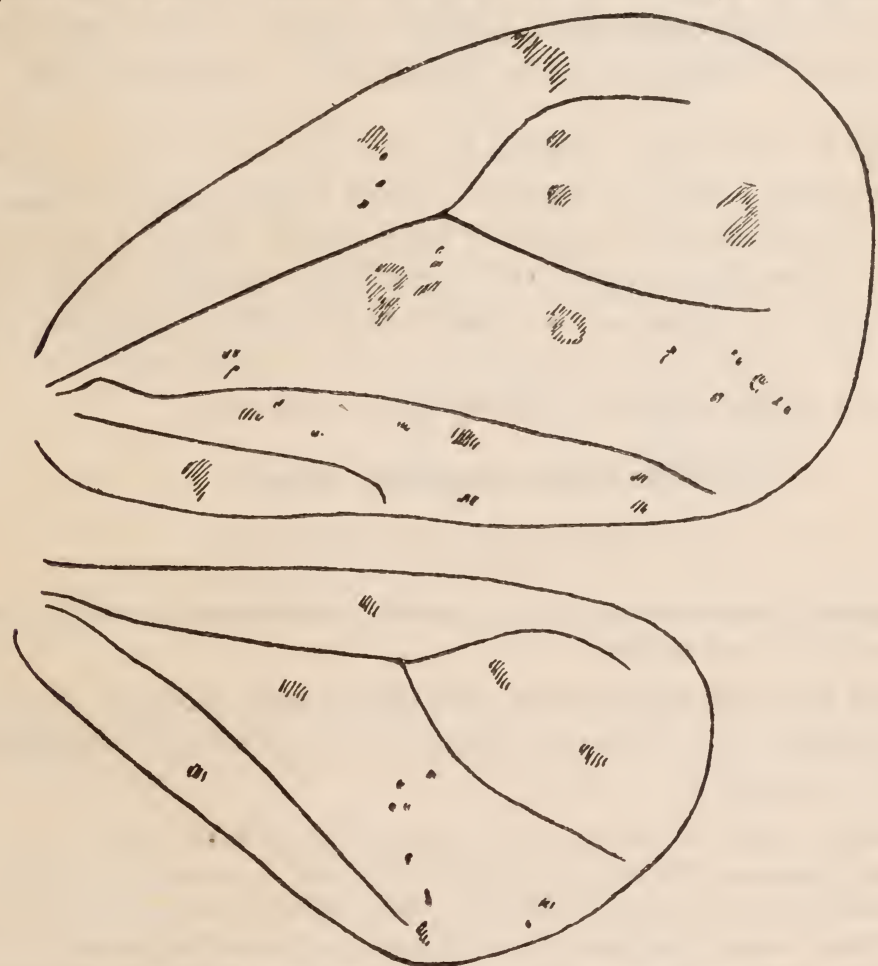

Fig. 10.-Wings of Aleurodicus conspurcatus. (Redrawn from Enderlein..)

half ochraceous yellow. Abdomen very small and narrow (male), its last segment about two and one-half times as long as wide, penultimate segment about as long as it is wide, in the case of the female short and contracted. Final forceps of the male very long and attenuated, at its termination curved inward, about at the distance of three-fourths of the last segment. Penis in the shape of staff-like appendix at the base of the forceps and situated between them, very short (only about one-fourth the length of the forceps), thin, and erected in a perpendicular direction. Front margin of the head, viewed from above, forming a somewhat rounded rectangular angle. 
Wings hyaline, powdered with white. Both the forewings and the hind wings provided with small, irregularly formed, brown spots that are sparsely scattered. Costa in the forewing fine, but distinct. Radial sector $(r)$ in both wings strongly bent in the middle toward the exterior margin. In both wings the cubitus terminates in the hind corner of the exterior margin. Cubitus in the forewing is strongly sinuate at its base, but near its end it is only slightly undulated and sinuate. "Analis" in the forewing fine, but can be followed distinctly as far as its bouchare in the middle of the posterior margin, not present in the hind wing. Media and cubitus in both wings not quite reaching the margin of the wings, and the radial sector terminating quite a distance from the margin of the wings.

Length of the body, male $2.5 \mathrm{~mm}$., female $2 \mathrm{~mm}$; length of abdomen, male $1.75 \mathrm{~mm}$., female $1 \mathrm{~mm}$.; length of forewings, male $2.5 \mathrm{~mm}$., female $3 \mathrm{~mm}$.; length of hind wings, male $2.1 \mathrm{~mm}$., female $2.75 \mathrm{~mm}$.; greatest expanse of forewings, male $1.5 \mathrm{~mm}$., female $2 \mathrm{~mm}$.; greatest expanse of hind wings, male $1.15 \mathrm{~mm}$., female $1.5 \mathrm{~mm}$.

Southern Brazil, Santa Catharina; 13 specimens.

\section{Aleurodicus destructor Mackie.}

(Pl. XIII, figs. 1-7; Pl. XIV, fig. 2.)

Aleurodicus destructor Quaintance, Mackie, Philippine Agricultural Review, vol. 5, p. 142 (1912).

Coconut leaves infested with this insect were received August 22, 1911, from Mr. G. E. Nesom, director of agriculture, Manila, P. I., with the statement:

This scale is often found upon the stems of young fruit and in some calses, due to their presence, the tree is unable to set fruit. According to the natives, trees infested with this insect often die. Many of the owners of coconut groves in the vicinity where this scale is prevalent are rather frightened, and seem to believe that if something is not done to check this insect their groves will be completely destroyed.

From the above it would appear that this insect is an important enemy of the coconut, exceeding, perhaps, in destructiveness its congener cocois, long known from the West Indies.

\section{DESCRIITION.}

Egg.-About $0.31 \mathrm{~mm}$. long, elongate in shape, yellow to brownish in color, dusted with powdered wax. Stalk short, eggs prostrate on leaf. Shell delicate, collapsing upon escape of larva, unmarked.

Pupa case.-Size 1.33 to $1.5 \mathrm{~mm}$. long by 0.83 to $1 \mathrm{~mm}$. widé, subelliptical to ovate in shape; some examples narrowed cephalad. 
Tech. Series 27, Bureau of Entomology, U. S. Dept. of Agriculture.

Plate XiIi.
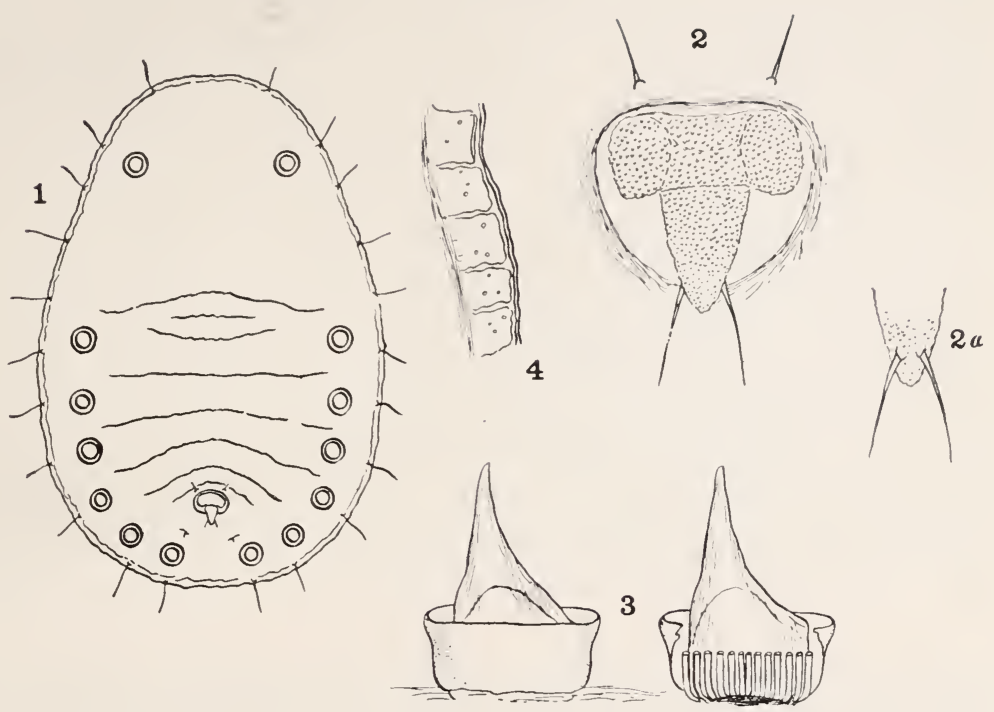

5
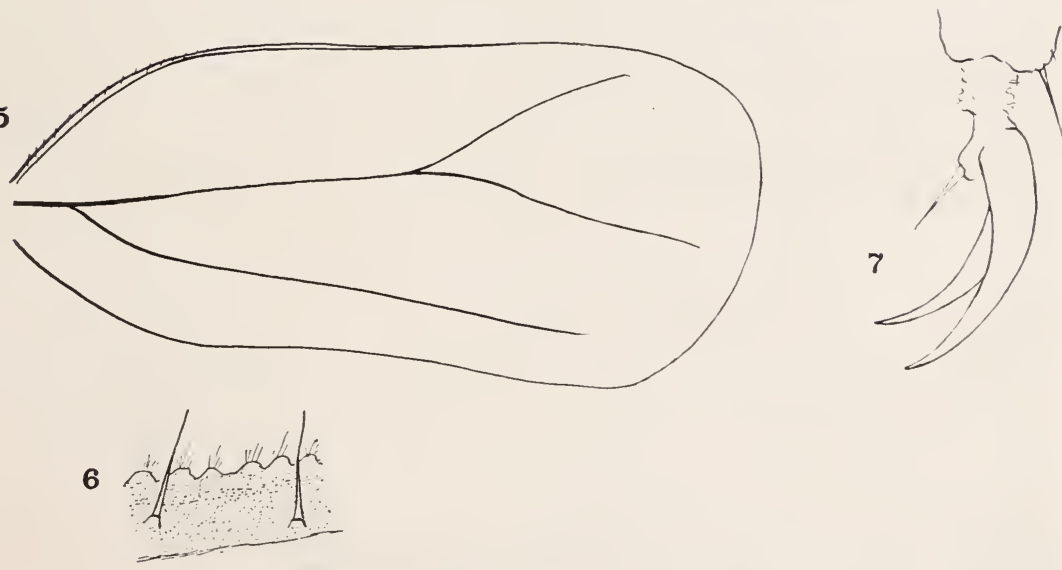

ALEURODICUS DESTRUCTOR.

Fig. 1.-Pupa case. Fig. 2.-Vasiform orifice of pupa case. Fig. 3.-Compound pore of pupa case. Fig. 4. -Margin of pupa case. Fig. 5. -Forewing of adult. Fig. 6. -Costal margin of forewing. Fig. 7.-Foot of adult. (Original.) 


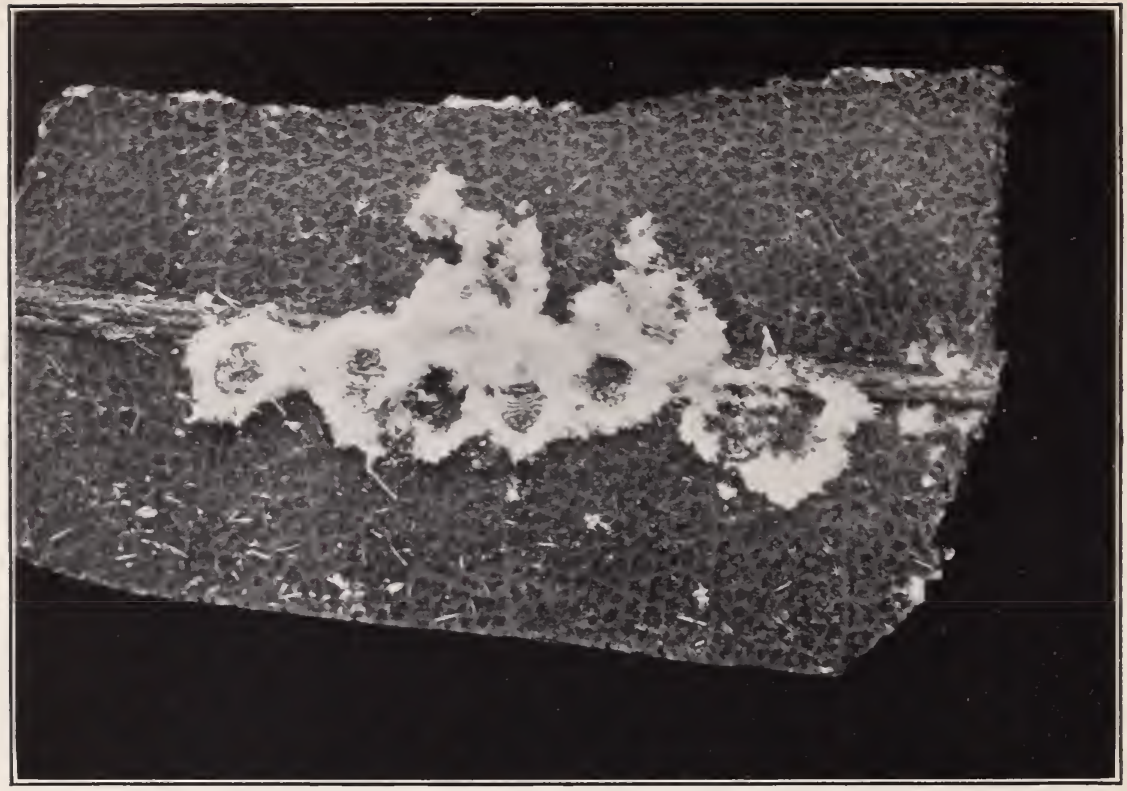

Fig. 1.-Pupe of Aleurodicus cocois on Leaf, Showing Waxy Secretion. (Original.)

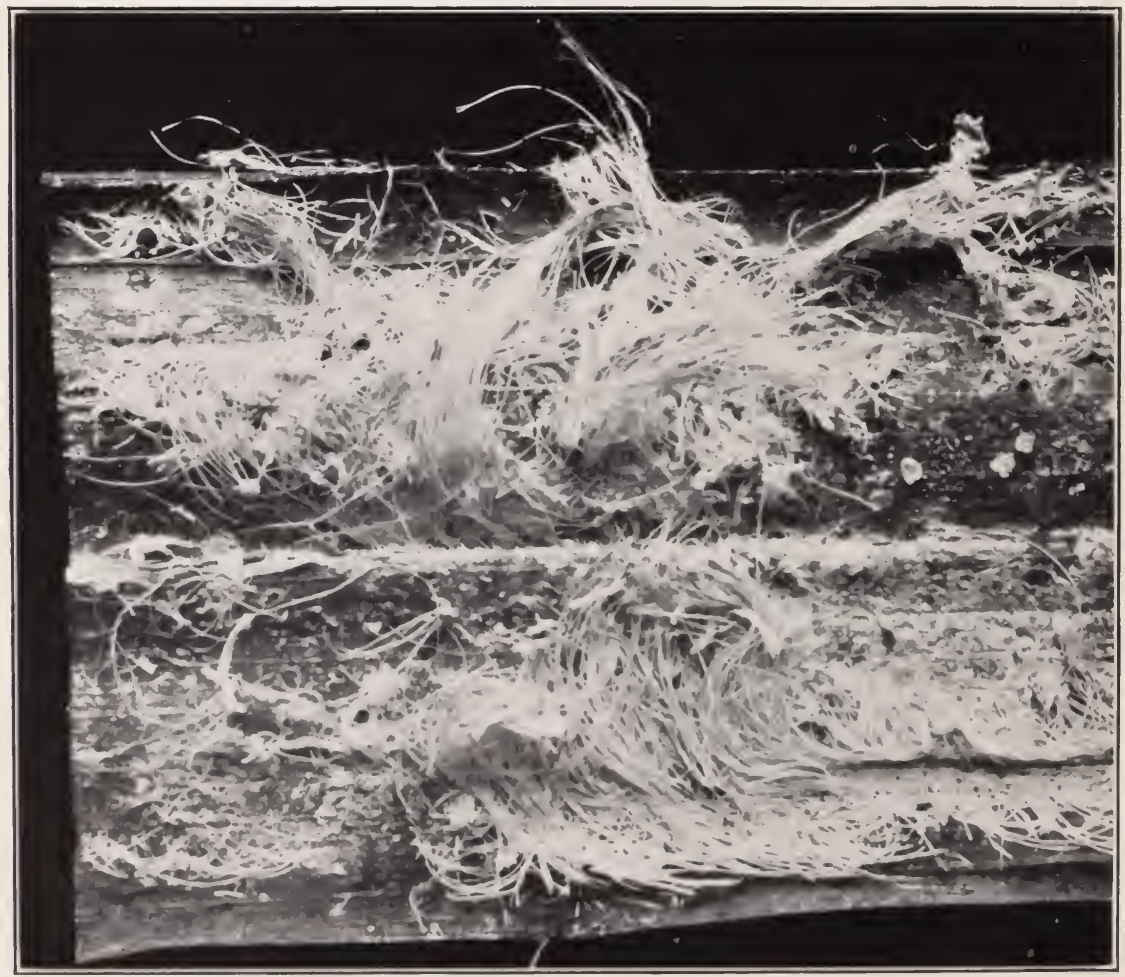

Fig. 2. Pupe of Aleurodicus destructor on leaf, Showing Waxy Secretion. 


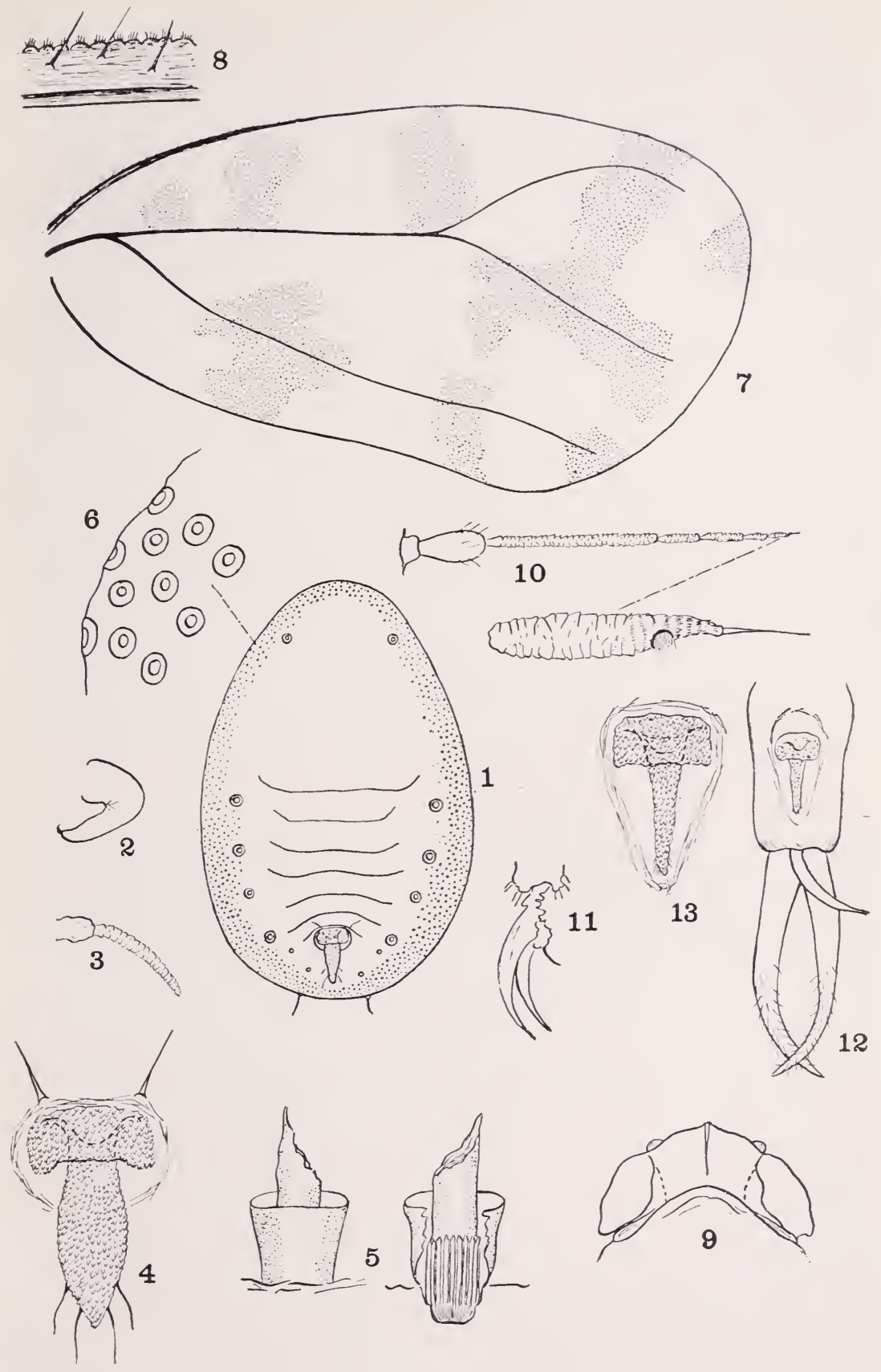

ALEURODICUS DUGESII.

Fig. 1.-Pupa case. Fig. 2.- Leg of pupa. Fig. 3.-Antenna of pupa. Fig. 4.Vasiform orifice of pupa. Fig. 5.-Compound pores of pupa. Fig. 6.-Margin of pupa. Fig. 7.-Forewing of adult. Fig. 8.-Costal margin of same. Fig. 9.-Head of adult. Fig. 10.- Intenna of adult. Fig 11.-Foot of adult. Fig. 12.-Dale genitalia. Fig. 13.-Vasiform orifice of adult. (Original.) 


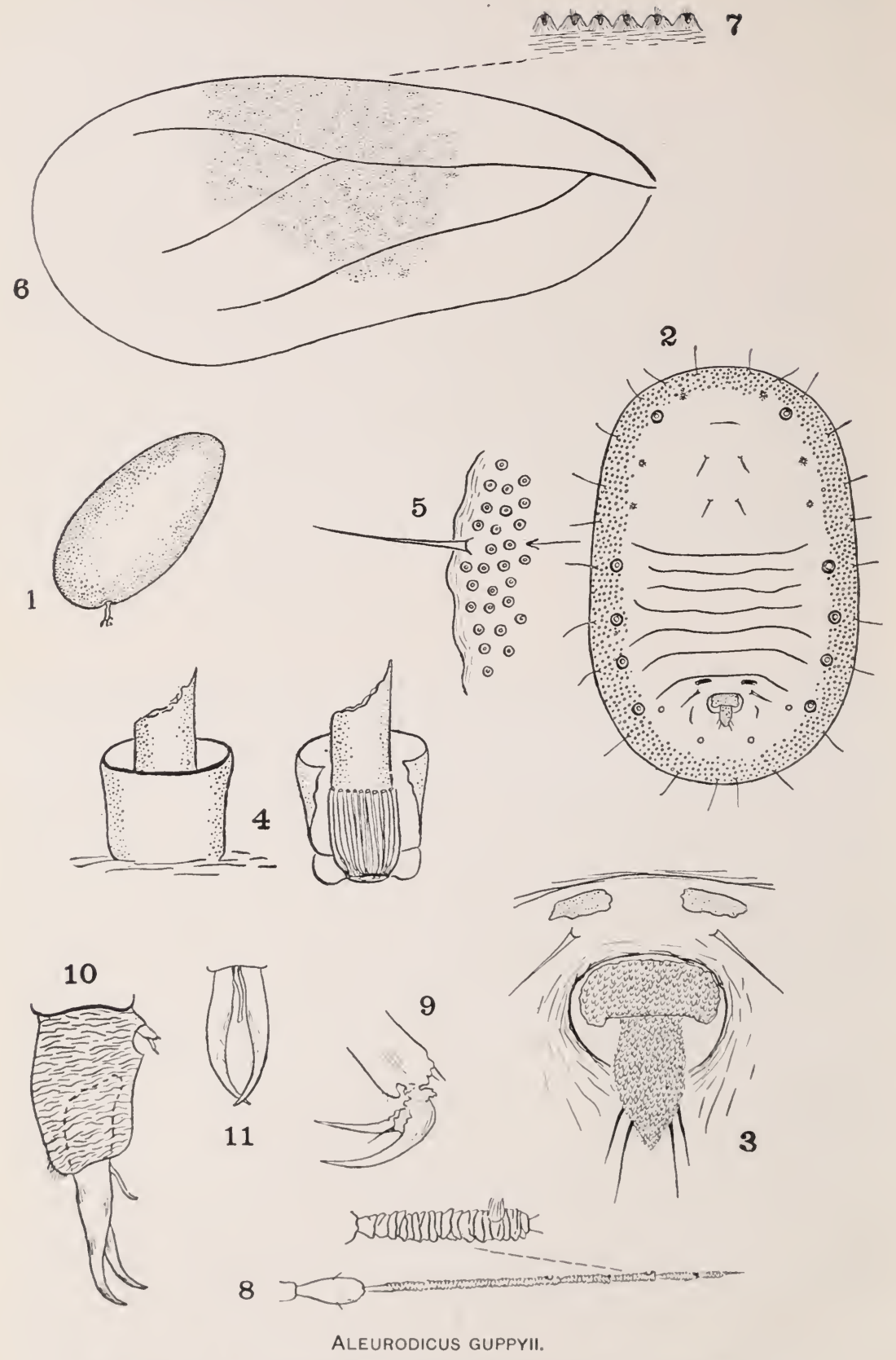

Fig. 1.- Eigg. Fig. 2.-Pupa case. Fig. 3.-Vasiform orifice of pupa ease. Fig. 4.- Compound pores of pupa case. Fig. 5.-Margin of pupa case. Fig. ti.Forewing of adult. Fig. 7. - Costal margin of forewing. Fig. S.-Antenna of adult. Fig. 9.-Foot of adult. Fig. 10.-Male genitalia. Fig. 11.-Same, dorsal view. (Original.) 


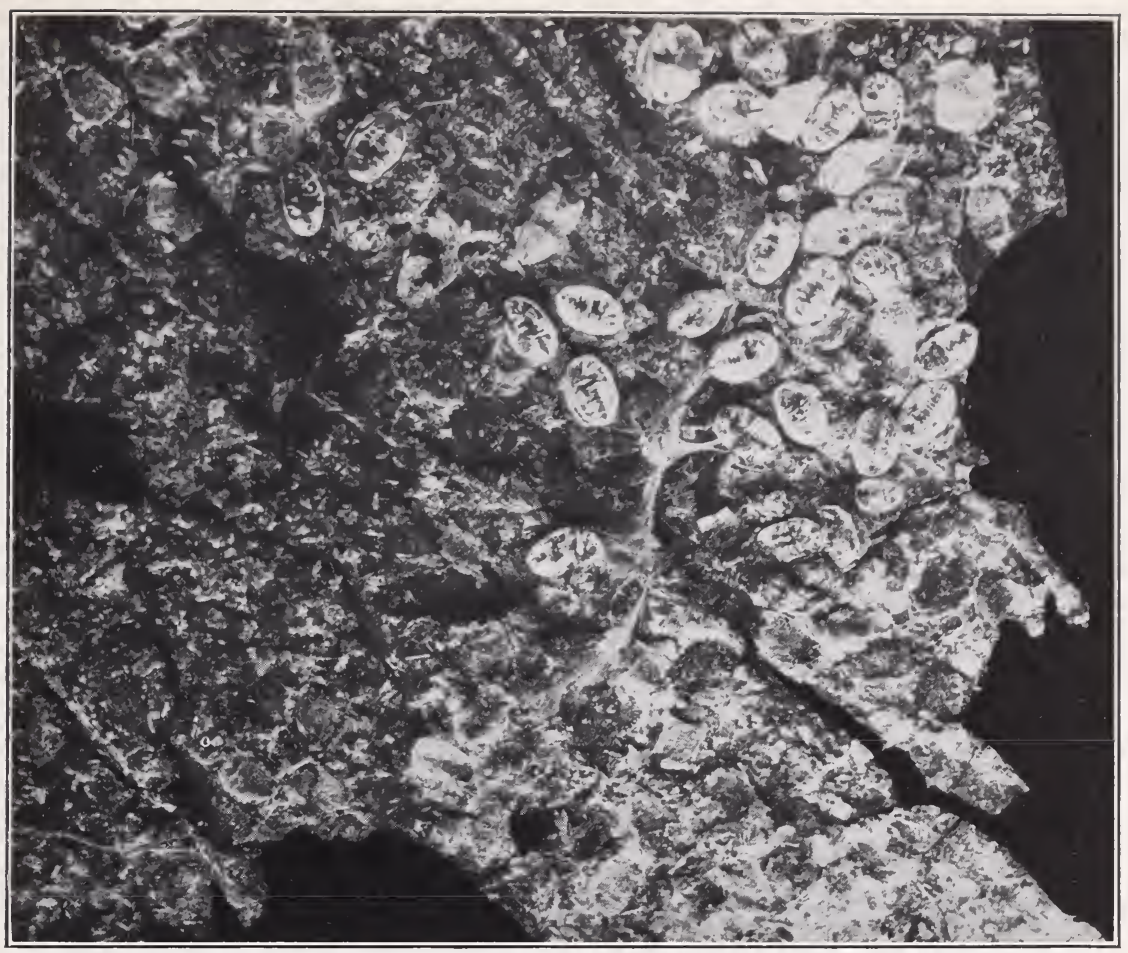

Fig. 1.-Pup ORIGINAL.)

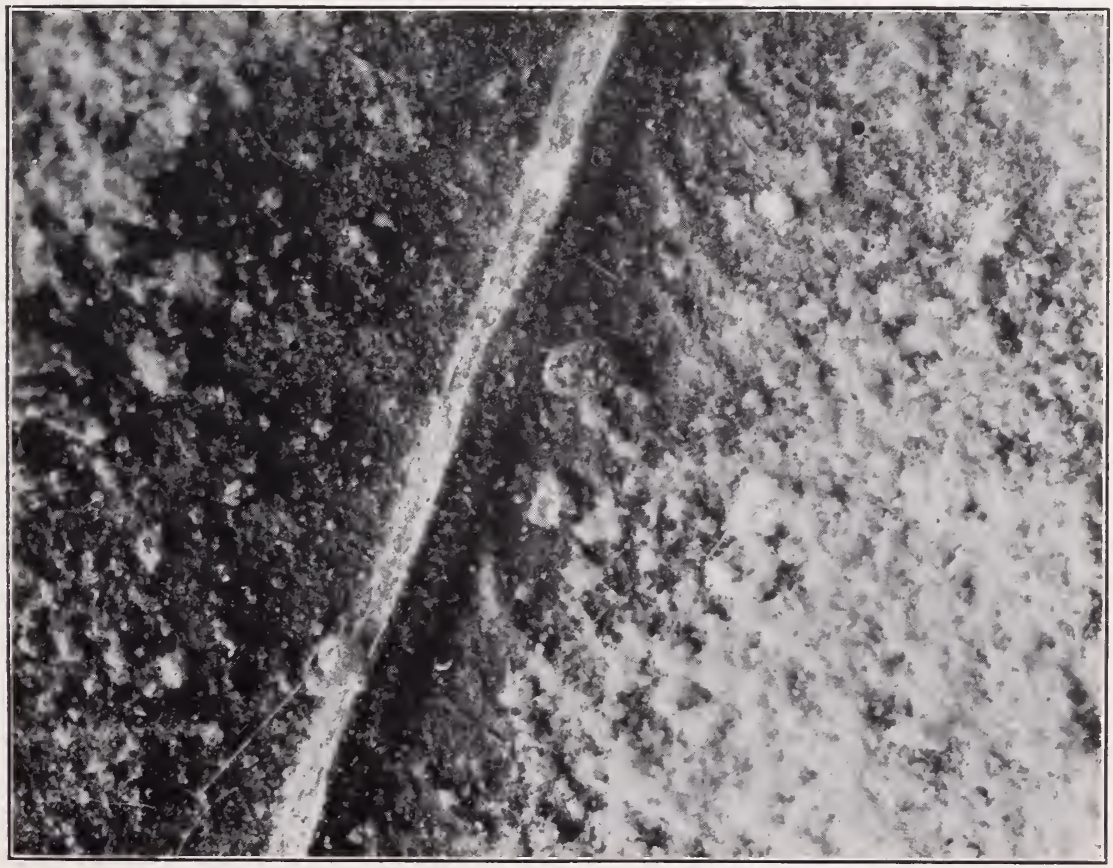

Fig. 2.-PuPA of Aleurodicus guppyil on LeAF, SHOWING WAXY Secretion. 


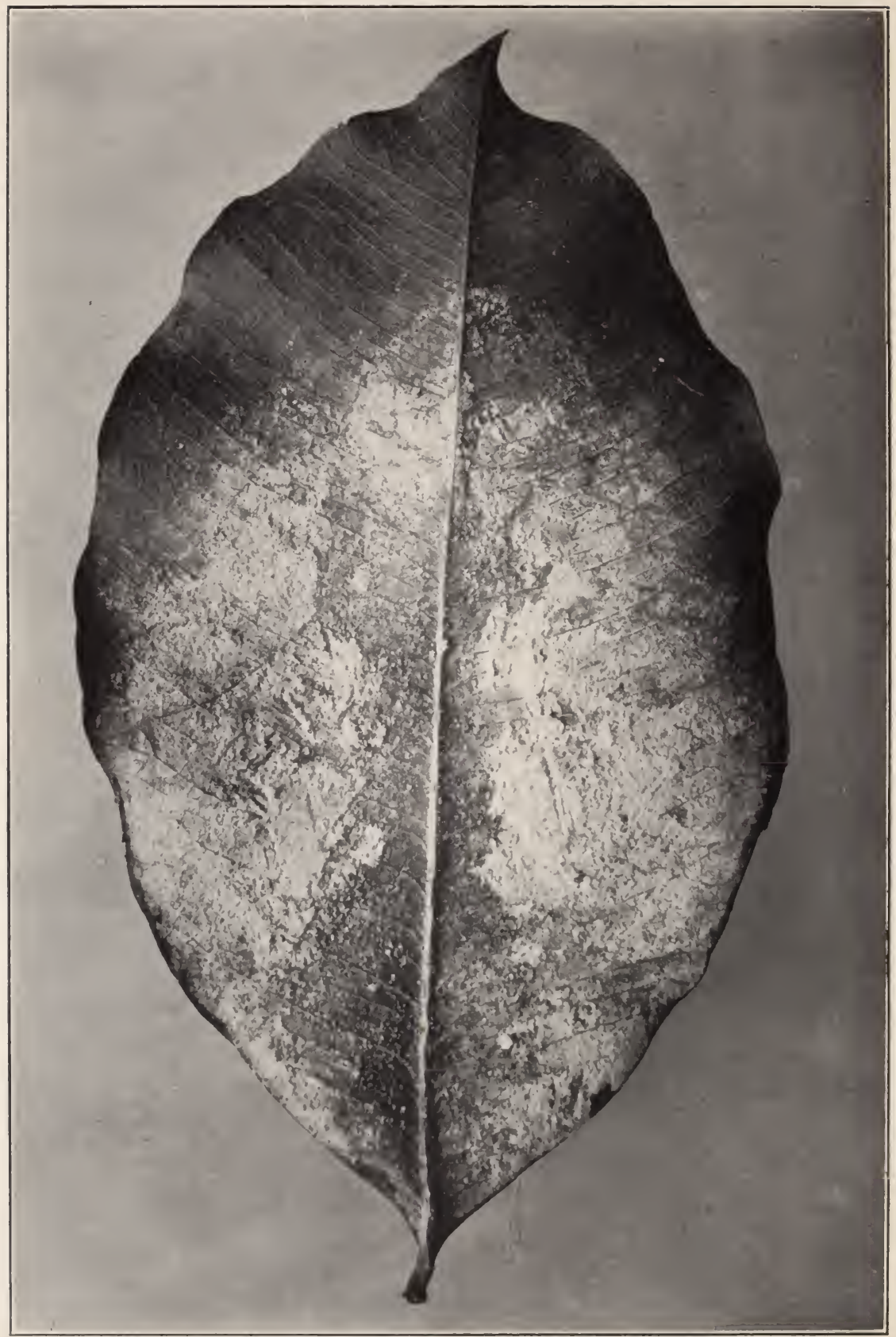

Leaf Infested With Aleurodicus guppyil, Showing Waxy Secretion of Pupa. ORIGINAL.) 
Dorsum but little convex, body segments quite distinct in the dried specimens (Pl. XIII, fig. 1). There is a very copious secretion of white wax covering the lower surface of the infested leaves and completely hiding the insects beneath (Pl. XIII, fig. 2). The wax rods, from the compound wax pores, are unusually long, attaining in more perfect specimens a length of from 12 to $15 \mathrm{~mm}$. Generally, however, these rods are more or less broken and are intermingled with bands or plates of wax from the marginal wax tubes. There is a short vertical fringe of white wax often persisting on the leaf after the pupa case has disappeared.

The color is yellowish to brownish, some specimens, as seen under hand lens, being dark brown. The empty case is colorless. There is a narrow marginal rim composed of the short, squarish wax tubes, the incisions being shallow and acute (Pl. XIII, fig. 4). On the dorsum there are seven pairs of very conspicuous compound wax pores, six pairs on the abdomen about equally developed, and a pair on the cephalic region of about half the size of the former. From the marginal area all around arise a series of spines, 10 to 12 on a side, and there is a pair cephalad of the vasiform orifice.

Vasiform orifice subcordate, about as wide as long. Operculum subrectangular, about twice as wide as long. Lingula spatulate, rather short and broad, bearing a pair of spines (Pl. XIII, fig. 2). The rudimentary legs and antennæ are quite evident on the ventral surface, and exhibit the usual structures for the typical forms of this genus.

Adult.-A single imperfect male was found among the pupæ on the leaves. The wings are without markings (Pl. XIII, fig. 5).

This species, from the structure of the pupa case, suggests neglectus, common on Anona spp., guava, Ficus, etc., in the West Indies, but differs in that the wings are not spotted or banded, in the large size of the two caudal pairs of compound wax pores, and there are differences in the lingula. From cocois it differs in numerous particulars, as will be noted on comparison. This is the third species of this genus recorded from outside of tropical America, though it may have been introduced in the Philippines along with its food plant.

Type.-No. 14766, U. S. National Museum. Described from numerous eggs, pupæ in balsam mounts, and infested leaves.

\section{Aleurodicus dugesii Cockerell.}

(Pl. XV, figs. 1-13; Pl. XVII, fig. 1.)

Aleurodicus dugesii Cockerell, Can. Ent., vol. 28, p. 302 (1896).

Specimens of this species are in the Bureau of Entomology collection from several localities in Mexico, and on several different food plants, as follows: Oaxaca, on Hibiscus; Guanajuato, on Anona and 
Hibiscus rosa-sinensis; Guadalajara, on Hibiscus; and on mulberry, locality unknown. The original description by Prof. Cockerell follows:

Length $1 \frac{2}{3} \mathrm{~mm}$.; length of anterior wing, $2 \frac{1}{4} \mathrm{~mm}$.; its greatest breadth nearly $1 \frac{1}{2} \mathrm{~mm}$. Pale grayish-ochreous, corered with white meal, abdomen beneath shining silvery. Wings white; upper wings iridescent, with markings similar to those of $A$. ornatus, but very pale gray and quite different in detail. There are four gray bands crossing the wings, of which only the third and fourth are joined by a longitudinal band. The first (basal) band bends abruptly inwards after crossing the main nervure, which branches so near the base of the wing that there are practically two nervures, the first gray band failing in the angle between them, but strong again beyond the second. Second gray band broad as far as the first nervure, just beyond it interrupted broadly, but continued as a large, nearly circular gray patch, the greater part of which is above the second nervure, which it meets at its fork; after that failing, but reappearing strongly a little way down the lowest branch of the nervure and thence passing downwards, becoming very faint. Fourth band broad, passing across the end of the fork, bent inwards, joining the continuation of the third band after the break, itself forking at its lower end. The curve of the fourth band leaves a white apical area in which there is a gray spot. There is also a gray spot at the tip of the second nervure.

The pupæe occur on the under sides of the leaves and are of the usual typeoval, flat, pale ochreous, with white mealy powder.

Habitat.-Guanajuato, Mexico, on Hibiscus rosa-sinensis. Sent by Dr. Alfred Dugès in great quantity. Dr. Dugès writes that it is also found on the largeleafed Begonia and other plants, and it does not appear to do them a great deal of harm. It is the first Aleurodicus described from Mexico, and is most nearly allied to the Jamaican A. ornatus, Cockerell. The genus now includes five species, all neotropical except the U. S. A. asarumis (Shimer, 1867).

\section{DESCRIPTIVE REMARKS.}

Egg.-About $0.3 \mathrm{~mm}$. long; stalk short, from one side of end; color dusky; shell unmarked.

Pupa case.-Size rather variable, from 1.15 to $1.3 \mathrm{~mm}$. in length, by 0.7 to $0.85 \mathrm{~mm}$. in width. Ovoid or subelliptical in shape; brownish in color, as seen on leaf, varying to plumbeous in some specimens, probably parasitized. Case moderately convex, raised somewhat by a vertical fringe all around of white wax (PI. XVII, fig. 1). Dorsum of case powdered with dirty white wax, and from the compound wax pores are produced the usual brittle glassy wax rods (Pl. XV, fig. 1).

Under microscope, empty case colorless, except the prominent lingula, which is dark brown. Abdominal segments distinct. Marginal fifth or sixth of case all around with many small round simple wax pores (Pl. XV, fig. 6). On dorsum also are seven pairs of compound wax pores, one on cephalic end and six on abdomen, the last two pairs being much reduced ( $\mathrm{Pl}$. XV, fig. 5). There is a pair of strong spines on caudal margin of case. 
Vasiform orifice large, cordate, about as broad as long. Operculum short and broad, the caudal margin concave. Lingula very prominent, spatulate, dark brown in color, bearing distally two pairs of spines (Pl. XV, fig. 4). On ventral surface legs and antennæ are quite distinct.

Adult female.-Forewings about $2.4 \mathrm{~mm}$. long by $1.3 \mathrm{~mm}$. wide; legs long and slender. Hind tibia $0.9 \mathrm{~mm}$. long; basal tarsal joint $0.23 \mathrm{~mm}$. long, distal tarsal joint $0.14 \mathrm{~mm}$. long.

Adult male.-Essentially as in female, though tibia and tarsus are slightly longer in each case. Valves of forceps long, narrow, and strongly curved at tip (0.86 $\mathrm{mm}$. in length).

Type.-No. 14764, U. S. National Museum.

Aleurodicus guppyii n. sp.

(Pl. XVI, figs. 1-11; Pl. XVII, fig. 2; Pl. XVIII.)

This species was received from Dr. F. W. Urich, Port of Spain, Trinidad, May 25, 1911, on Rheedia latiflora L. The large brown maculation on forewing of adult insect readily separates it from any form heretofore described. The insect infests the lower surface of the large leathery leaves of its host plant, principally the basal twothirds (see Pl. XVIII). This area is more or less covered with a powdery white wax secreted from the abdomen of the adults, in which are embedded the immature stages.

DESCRIPTION.

Egg.-Size about 0.32 by $0.16 \mathrm{~mm}$. Subelliptical in outline, the stalk very short, attached to one side of end of egg. Color on leaf brownish; lighter under transmitted light, without markings (Pl. XVI, fig. 1).

Pupa case.-Size rather variable, averaging about 1.13 by $0.70 \mathrm{~mm}$. Elliptical in outline, the dorsum but little convex, though the case is prominently raised from the surface of the leaf by a vertical rim all around of white wax. Dorsum void of secretion, except the usual glassy wax rods from the compound wax pores. This secretion, however, is meager, the rods being short and fragmentary (Pl. XVI, fig. 2).

On leaf, under hand lens, the color is yellow or brownish-yellow; and under microscope yellowish white to darker. Margin of case with very light crenulations, but no distinct marginal rim. On the submarginal area, however, are innumerable closely set small pores, forming a broad band all around the case (Pl. XVI, fig. 5).

On the dorsum are seven pairs of compound wax pores (Pl. XVI, fig. 4), one pair on the cephalic region and four pairs on the ab$61201^{\circ}-13-5$ 
dominal region, and two pairs of smaller pores on anal segments; on caudal end of case there are two pairs of scalelike markings on the thorax, and a pair of simple pores near cephalic margin. Abdominal segments distinct.

From within the margin of case all around arises a series of slender spines, or setæ, about 12 on each side. There is a pair of minute setæ just cephalad of the vasiform orifice, and two pairs of setæ are present on the thoracic region.

Vasiform orifice (Pl. XVI, fig. 3) subcordate to subcircular, little longer than wide. Operculum subrectangular, concave on distal margin, almost twice as wide as long. Lingula as usual, spatulate, with two pairs of spines on distal end. Operculum and lingula minutely spinose. On ventral surface of case the legs are quite evident, terminating in a single, hooked claw. Antenna as usual, two-jointed, the distal joint numerously ringed.

Adult female.-Length 1.9 to $2 \mathrm{~mm}$. Forewing, length $2.60 \mathrm{~mm}$., width $1.23 \mathrm{~mm}$. Body and wings dusted with white wax, and there is a copious waxy secretion from ventral surface of abciomen of both sexes. General color of head and thorax dark brown to blackish, abdomen bright red; legs, margins of wings, wing veins, and antennæ reddish.

Eyes plumbeous, constricted, the smaller division below. Forewing (Pi. XVI, fig. 6) marked across the middle with a conspicuous, broad brownish band. This arises from the cephalic margin of the wing and extends caudad usually beyond the media well toward the caudal margin of wing. Hind wing without markings.

Antennæ as usual (Pl. XVI, fig. 8). Tibia of hind leg $0.8 \mathrm{~mm}$. long; first tarsal joint $0.26 \mathrm{~mm}$., second tarsal joint $0.13 \mathrm{~mm}$. in length.

Adult male.-Length $1.3 \mathrm{~mm}$.; valves of anal forceps $0.7 \mathrm{~mm}$. long, curved, inserted in the cylindrical anal segment (Pl. XVI, figs. 10, 11). Forewing $2.1 \mathrm{~mm}$. long by $0.95 \mathrm{~mm}$. wide, marked as described for female. Hind wing unmarked. General color dusky to blackish, more or less covered with white waxy powder.

Type.-No. 14768, U. S. National Museum. Described from numerous eggs, pupæ, and adults of both sexes. Dedicated to Mr. P. L. Guppy.

\section{Aleurodicus jamaicensis Cockerell.}

(Pl. XIX, figs. 1-5.)

Aleurodicus jamaicensis Cockerell, Proc. Acad. Nat. Sci., Phlla., vol. 54, p. 280 (1902).

The type of this species consists of a single parasitized pupa case in a balsam slide mount. From this scant material and the imperfect original description we are quite unable to obtain an adequate con- 

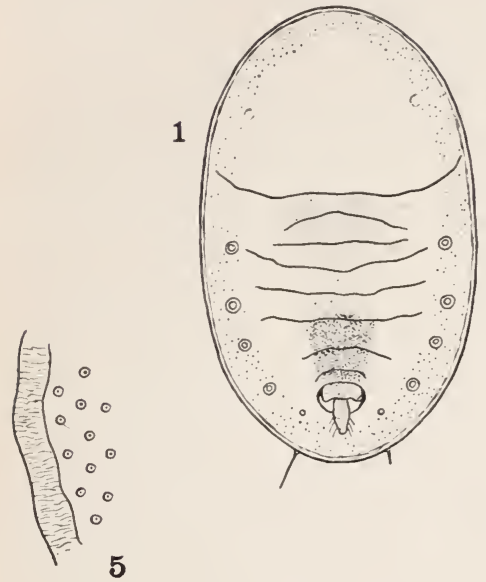

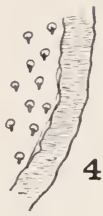

2
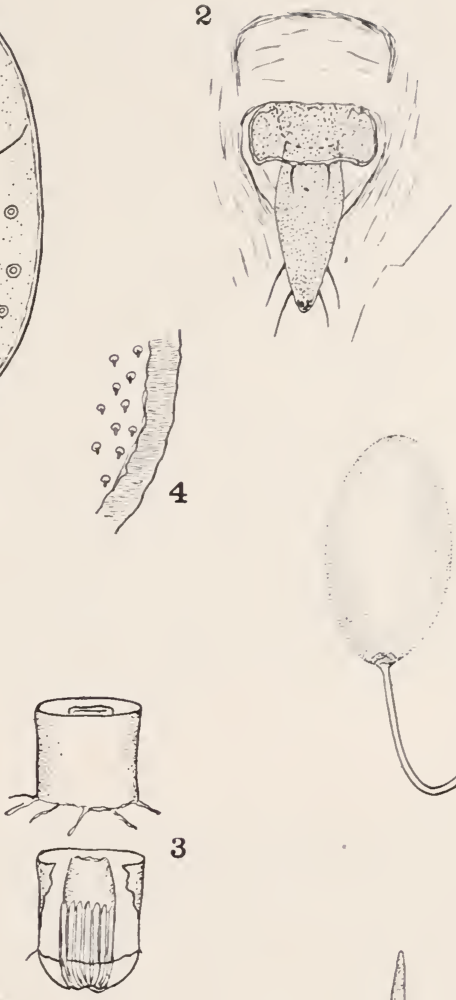

11
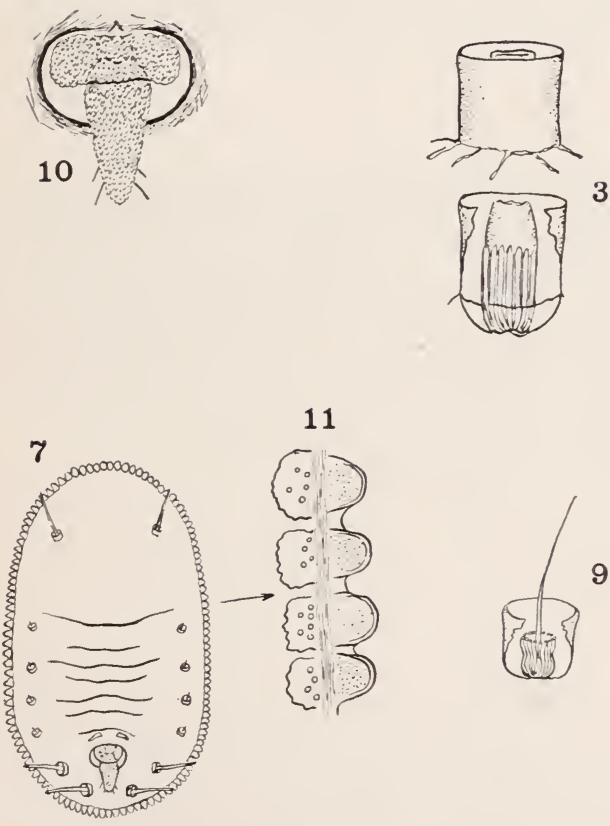

9

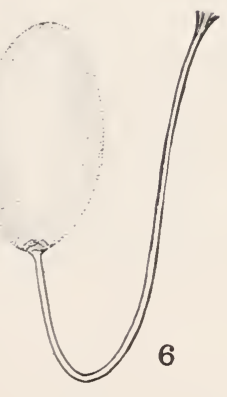

3
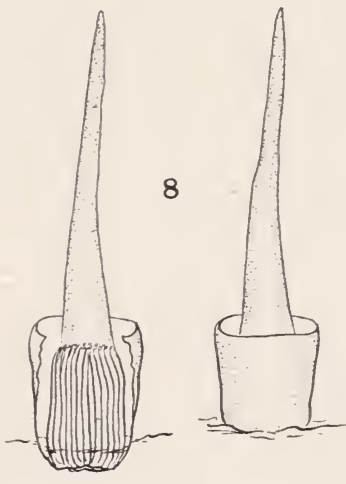

\section{ALEURODICUS JAMAICENSIS AND ALEURODICUS HOLMESII.}

Aleurodicus jamaicensis: Fig. 1.-Pupa case. Fig. 2.-Vasiform orifice. Fig. 3.Compound pores of pupa case. Fig. 4--Margin of parasitized pupa case. Fig. 5.-Margin of normal ease. Aleurodicus holmesii: Fig. 6.-Egg. Fig. 7.-Pupa case. Fig. 8.-Compound wax pores. Fig. 9.-Reduced compound wax pore. Fig. 10.- Vasiform orifice of pupa. Fig. 11.-Margin of case. (Original.) 

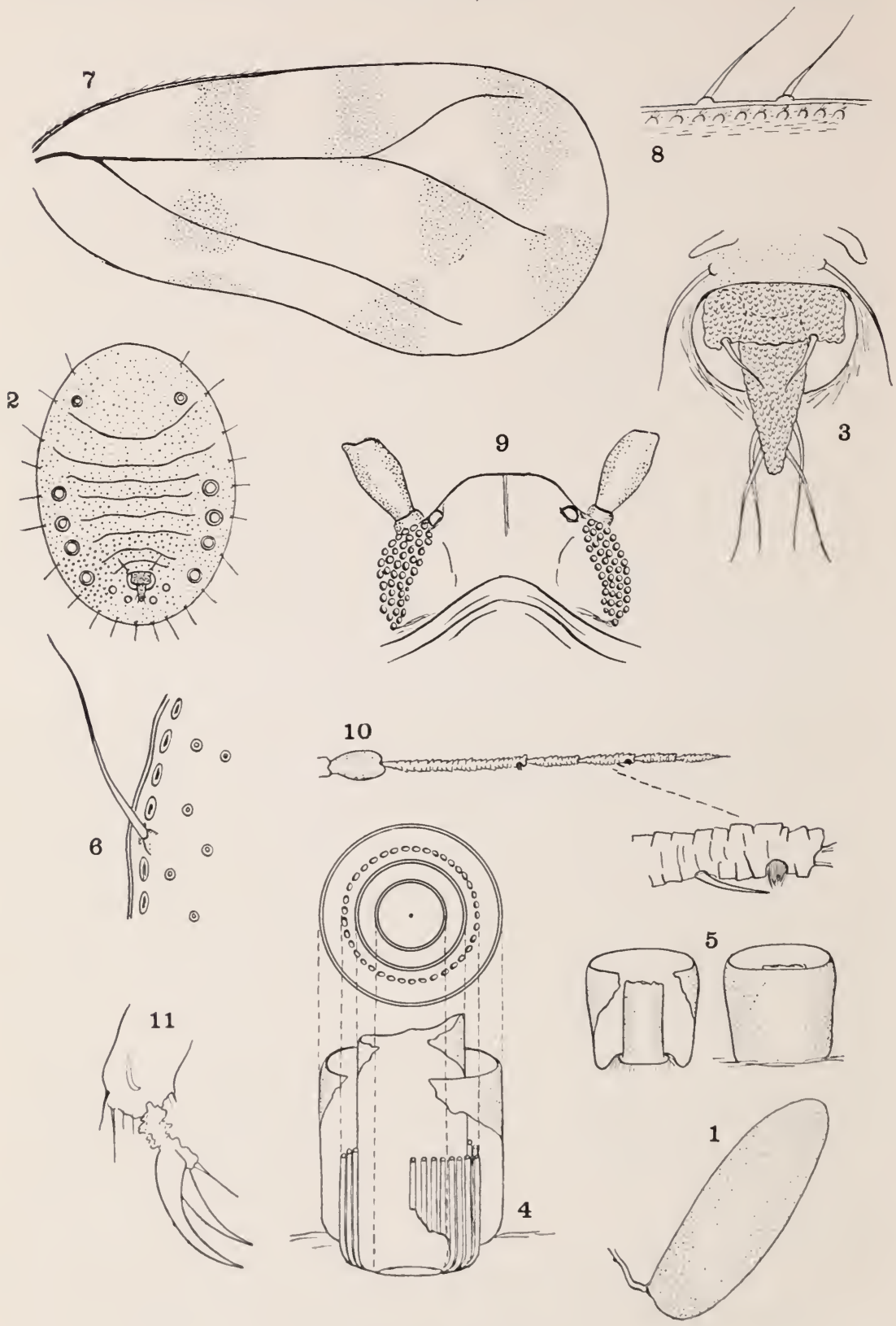

ALEURODICUS NEGLECTUS.

Fig. 1-Egge, Fige '?. P'upia case. Fig. 3. Vasiform orifice of pupa ease. Fig. 4.

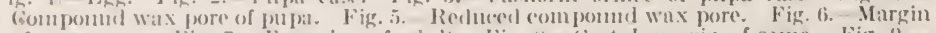
of pulpa case. Fig. 7. Forewing of achuld, Fig. s. costal margin of same. Fig. ?. Hearl of adult. Fig. 10.- Intemin of inlult. Fig. 11.-Foot of achnlt. (Original.) 


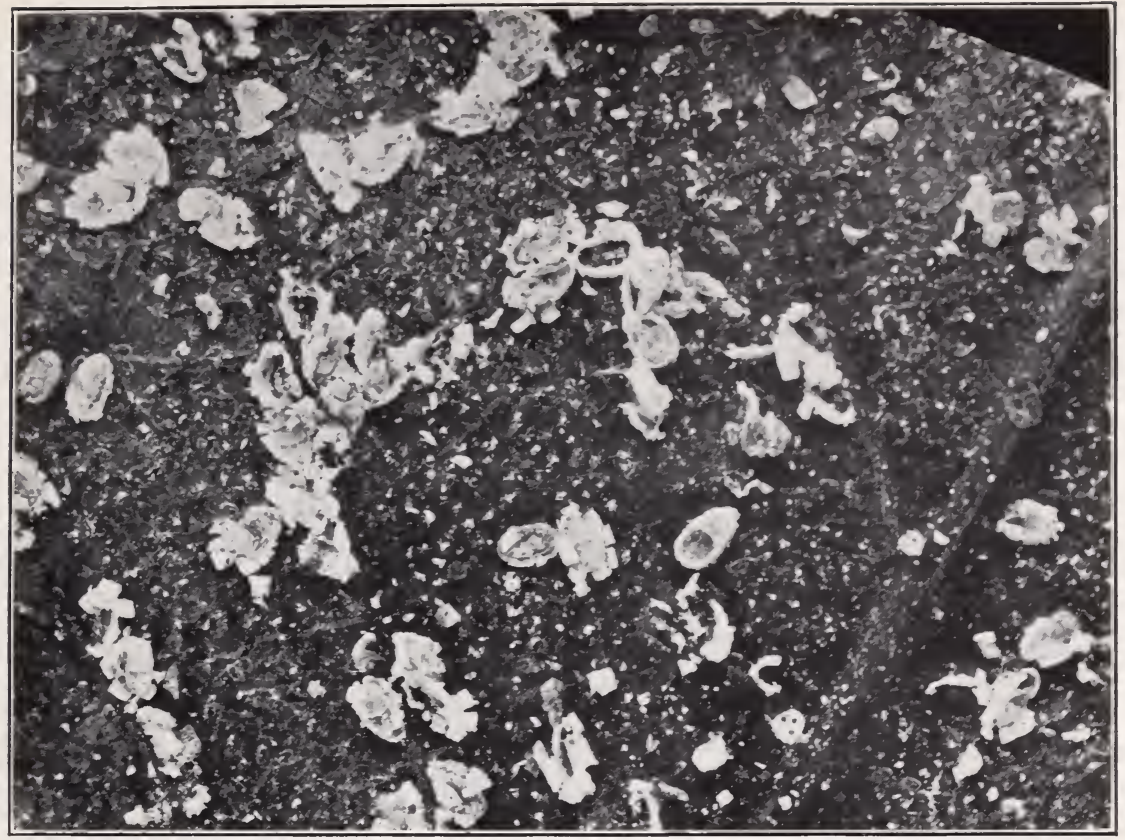

Fig. 1.-Aleurodicus holmesil: Pupe on leaf, Showing Wayy Secretion. (Original.)

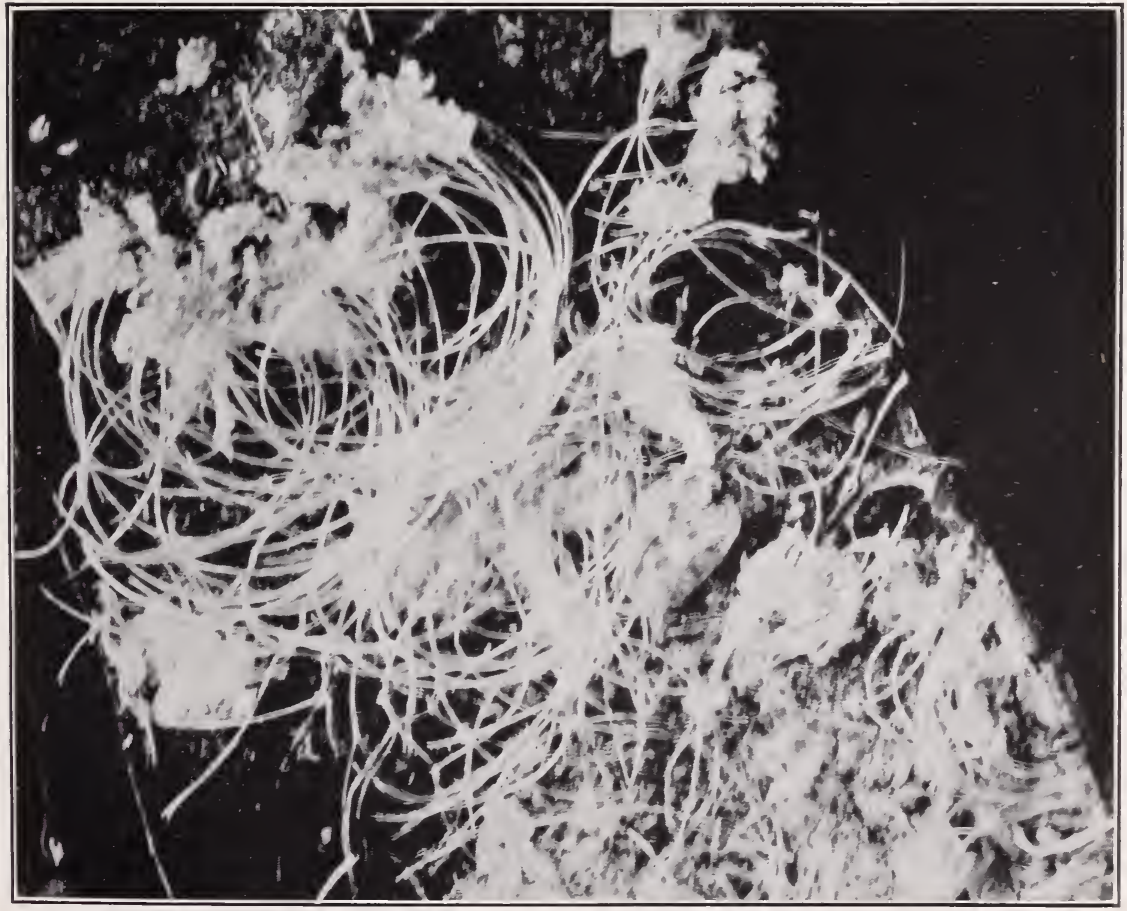

Fig. 2.-Aleurodicus neglectus: Pupe on leaf, Showing Waxy Secretion. 

ception of the characteristics of this form. Prof. Cockerell's description follows:

\section{ORIGINAL DESCRIPTION.}

Alcurodicus jamaicensis was collected by the writer at Kingston, Jamaica, in 1893. The pupa is small (hardly $1 \frac{1}{2} \mathrm{~mm}$. long), with vertical walls, margin resembling that of pulvinata; color bright yellow, with a brownish dorsal cloud, and a diamond-shaped black patch just anterior to the vasiform orifice. Other characters shown in fig. 2.

\section{DESCRIPTIVE REMARKS.}

Pupa case.-Size $1.3 \mathrm{~mm}$. long by $0.89 \mathrm{~mm}$. wide. Color yellow, with dark brown markings as shown in the figure. There is a submarginal area all around marked with many simple wax pores which, in the present specimen, have mostly developed short, stout, spinelike structures, probably due to parasitism (see coccoloboe, p. 50). On the abdomen are five pairs of compound pores, the caudal pair being much reduced in size. (The usual cephalic pair is also probably present, but can not be verified in the specimen at hand.) Caudal margin of case with a single pair of spines. Margin entire. Vasiform orifice cordate, about as broad as long. Operculum short, about twice as broad as long, ends rounded; caudal margin coarsely sinuate and bearing a pair of spines. Lingula large, exserted, subspatulate, bearing distally two pairs of spines.

Type.-No. 14771, U. S. National Museum.

Aleurodicus holmesii (Maskell).

(Pl. XIX, figs. 6-11; Pl. XXI, fig. 1.)

Aleyrodes holmesii Maskell, Trans. N. Z. Inst., vol. 28, p. 435 (1895). Described as Aleyrodes by Maskell and transferred to Aleurodicus by Cockerell (Bul. 67, Fla. Agr. Exp. Sta., p. 644, 1903).

\section{ORIGINAL DESCRIPTION.}

Larva dull-yellow, elliptical, flattish ; length about 1/80 in. Margin thickened, almost entire, the crenulations being very minute and confused. Dorsum bearing, on the thoracic region, six strong rather short spines; of these, two are median, the four others submarginal. In the earliest state there is no fringe, but in the latest stage there is a fragmentary short fringe of white wax.

Pupa-case dull-yellow, rather lighter colored than the larra; form elliptical, flattish, and rather thick; length about 1/25 in. Abdominal segments moderately distinct. Dorsum bearing a submarginal series of strong short spines; two of these on the cephalic region and four on the posterior abdominal region are large and conspicuous, the other eight (four on each side), on the thoracic region, are smaller. From these spines is produced a quantity of white waxy secretion, which is very fragmentary, often entirely absent; it scarcely ever seems to completely cover the dorsum. Margin very distinctly and conspicuously crenulated with large thick segments; these produce a fringe of closely- 
adjacent waxy tubes, which at first is flat, then becomes a rather thick ring or cushion, and at last becomes so thick as to raise the pupa somewhat high above the leaf, and then it seems as if resting on a rery elegantly-fluted white wall; vasiform orifice subelliptical, with concave anterior edge and broadly rounded sides and end; operculum broad and short, the posterior edge concave; lingula very long, extended beyond the orifice. subcylindrical, with emarginate sides and compressed extremity, the end rugose, with four rather long and many very short setæ or hairs.

Adult form unknown.

Hab. in Fiji, on Psidium sp. My specimens were sent by Mr. R. L. Holmes.

The arrangement of the dorsal spines, and the peculiar lingula, will distinguish this species.

\section{DESCRIPTIVE REMARKS.}

The type of this species was unfortunately not in the Maskell collection. We have received, however, what is evidently the same insect from Mr. R. S. Woglum, of this bureau, collected at the Botanic Garden at Buitenzorg, Java, January, 1911, on a plant of the family Sapindaceæ, from which material we have drawn up the following description:

The larvæ and pupæ occur promiscuously over the underside of the leaves, though when few or moderately abundant they occur more along the midrib and larger veins. The surface of foliage on infested plants is more or less covered with the usual growth of "sooty fungus," nourished on the excretion from these insects.

Egq.-Size about 0.2 by $0.1 \mathrm{~mm}$., subelliptical, the distal end pointed. As seen on leaf, dark-brown to blackish in color; many specimens iridescent, without markings. Stalk attached at basal end and about twice length of egg. Eggs scattered promiscuously over leaf and prostrate. In hatching the shell splits longitudinally in two equal parts, which are held together at base (Pl. XIX, fig, 6).

Larva (first stage).- Size about 0.26 by $0.153 \mathrm{~mm}$., elongate elliptical in shape, though somewhat narrowed caudad. Around the margin is a short rim of white waxy secretion. Color on leaf light brown, under microscope light yellowish to whitish. Eye spots reddish, elongate, and often divided. Margin without evident crenulations, except a shallow and variable sculpturing on cephalic end. Dorsum uniform, without evident pores, but little convex. Margin all around with minute setr, the two caudal pairs strongest. Vasiform orifice relatively large, cordate in outline, about as wide as long. Operculum half as long as orifice, the sides rounded. Lingula spatulate, little if at all extended, minutely spinose.

Pupa case.-Size about 1 by $0.53 \mathrm{~mm}$., elliptical in outline, the dorsum little convex; case raised on a vertical rim, all around of white wax, apparently deflexed from the large wax tubes on margin of case. In addition to the above secretion the dorsum is covered with a plate of fused wax, through which project the compound wax 
pores, and the body segments are fairly well indicated (Pl. XIX, fig. 7). From the compound wax pores are produced rather short, brittle, glassy wax rods, usually much broken and lying over surface of leaf. Color on leaf dirty white to yellowish, the empty case clear white. There is no well-marked marginal rim. The margin bears all around conspicuous short wax tubes, broadly rounded distally (Pl. XIX, fig. 11). Abdominal segments moderately distinct, thoracic segments less so. On each side are six compound wax pores, a pair on cephalic region, and five pairs on abdominal region. From the center of each of the two caudal pairs of wax pores and from the cephalic pair arises a strong, brownish-colored process or spine, which is quite conspicuous and morphologically appears to correspond with the central rod-like process in the compound pores in other species of the genus.

This spine-like structure is also present in the remaining wax pores, though much reduced (Pl. XIX, figs. 8 and 9 ). There is a pair of minute spines on the caudo-lateral margin.

Vasiform orifice (Pl. XIX, fig. 10) subcircular in outline, the cephalic margin a straight line, a little wider than long. Operculum short, about twice as broad as long, cephalic margin straight, caudal margin broadly concave, and the ends rounded.

Lingula large, spatulate, somewhat narrowed at base, and bearing distally two pairs of spines. Operculum and lingula minutely setose.

On rentral surface of case legs and antennæ inconspicuous; legs short, conical, without claws. Antennæ short, subronical, ending in a spinulous process and apparently but one-segmented. These structures differ notably from those in typical forms of the genus, wherein the antennæ are two-jointed, the distal joint long and ringed, and each leg terminating in a single claw.

Adult.-Unknown.

\section{Aleurodicus neglectus n. sp.}

(Pl. XX, figs. 1-11; Pl. XXI, fig. 2.)

Guava leaves infested with this insect were collected by Mr. Albert Koebele, at Para, Brazil, in 1882, and forwarded to the Bureau of Entomology. Specimens of the same insect were also received from Robert Newstead on Ficus bengalensis and Anona squamosa, collected in Demerara in 1892. With the appearance of the description of Aleurodicus anonce by Douglas in $1892,{ }^{20}$ the above two lots of material were erroneously referred to anonce and so labeled and carried in the Bureau of Entomology collection, as was also a distinct and much larger species, with clear wings, $A$. giganteus, collected by $\mathrm{Mr}$. Koebele December 28, 1882, at Pernambuco, Brazil. 
The senior author in studying the forms of Aleyrodidæ in the bureau collection ${ }^{21}$ accepted these determinations without critical examination of the material, and thus fell into the error of using the pupæ of neglectus and the adults of giganteus in characterizing anonce in the table of species (1. c., p. 43), and these two species were confused in stating the geographical distribution and food plants of anonce (p. 44). A. neglectus differs from anonce in that the wings of the adult are spotted with dusky. In anonce the wings are stated to be snowy white. A. anonce differs from giganteus in its smaller size and in the shape and structure of the pupa case, notably the presence on the caudal region of the two pairs of reduced compound pores, quite absent in giganteus.

Aleurodicus neglectus was also received from H. Caracciola, Port of Spain, Trinidad, September 28, 1896, on Anona reticulata; and again, from Trinidad, June 7, 1907, on coconut, from Mr. O. WV. Barrett. March 11, 1911, a further lot of material of this species was forwarded by Dr. F. W. Urich, Port of Spain, Trinidad, on Anona squamosa. The species is therefore known from Para, Brazil, and Trinidad, and from the following host plants: Anona reticulata, A. squamosa, Anona sp. (Brazil), and the coconut, Cocos nucifera.

This insect and $A$. destructor on coconut from the Philippines are noteworthy on account of the large size of the compound wax pores of the pupa case and the rather elongate and distally narrowed lingula.

\section{DESCRIPTION.}

Egg.-Length $0.3 \mathrm{~mm}$., light yellow, unmarked; stalk very short; egg lying prostrate on leaf (Pl. XX, fig. 1).

Pupa case.-Size about 1.3 by $0.92 \mathrm{~mm}$., broadly elliptical in outline. Dorsum little convex, the body segments distinct (Pl. XX, fig. 2). There is a copious secretion in the form of more or less fluted bands or masses of white wax from the simple dorsal and submarginal wax pores, extending out on leaf all around, several times the width of the case. From the compound wax pores are produced the long glassy wax rods usual in the genus, but their length in this species is remarkable and very similar to $A$. destructor. The pupe on the leaf are quite hidden under the large mass of wax, which renders them quite conspicuous. In the copious wax on the lower surface of the case the adults occur in numbers. There is evidenced a tendency to congregate along the midrib of the leaf, though individuals are also scattered over the general leaf surface (Pl. XXI, fig. 2).

The color of the case, denuded of wax, is yellowish to darker, some specimens varying to plumbeous. Margin of case apparently entire; just within margin all around is a closely set row of simple wax pores (Pl. XX, fig. 6) and similar pores are scattered generally over 

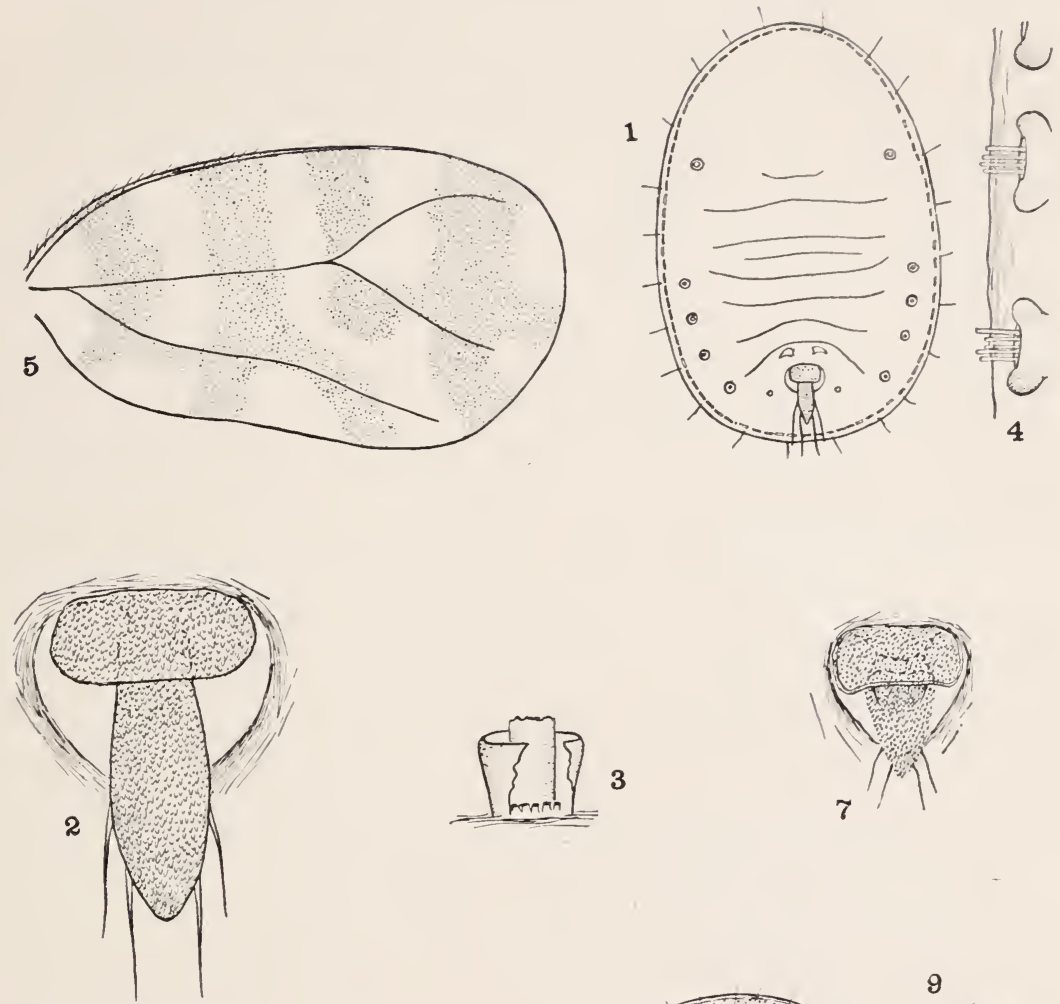

3

7
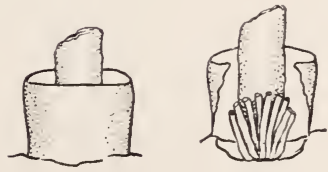

8

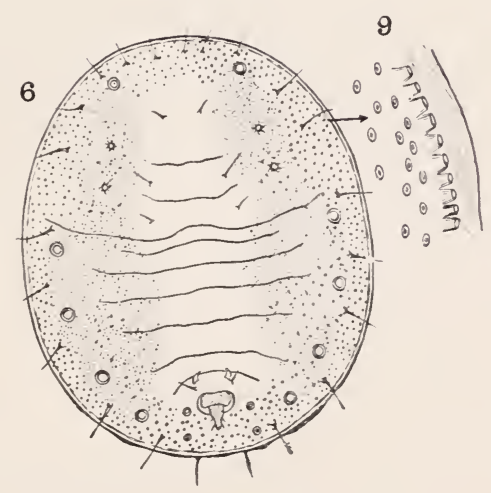

ALEUROdicus ornatus and ALEUROdicus pUlvinatus.

Aleurodicus ornatus: Fig. 1.-Pupa case. Fig. 2.-Vasiform orifice of pupa case. Fig. 3.-Compound pore of pupa case. Fig. 4.-Margin of case. Fig. 5.-W Wing of adult. Aleurodicus pulvinatus: Fig. 6.-Pupa case. Fig. 7.-Vasiform orifice. Fig. 8.-Compound pore of pupa case. Fig. 9.-Mfargin of the case. (Original.) 

the dorsum and from them is produced the waxy secretion before mentioned. On the dorsum of case are the usual compound wax pores (Pl. XX, figs. 4, 5) from which arise the long curling wax rods. In the present species the pores are unusually large, measuring 0.064 $\mathrm{mm}$. in diameter. These pores occur as follows: Four pairs on the abdominal region, two pairs of smaller pores on the caudal end of case, and two on each side of the vasiform orifice. On the cephalic end of the case is also a pair, though they are somewhat smaller than the pores on the abdomen.

Within the margin of the case all around is a row of spines, 11 or 12 to each side. There is also a pair of spines just cephalad of the vasiform orifice.

Vasiform orifice (Pl. XX, fig. 3) subcordate; operculum rectangular, about half filling the orifice, the caudal margin notched on each side, and bearing a pair of spines. Lingula exserted, elongate, and narrowed distally more than usual and with two indentures on each side near end, from each of which arises a strong, often curved spine. On the ventral surface the legs and antennæ are distinct.

Adult female.-Length of body about $1.7 \mathrm{~mm}$. Length of forewing $2.27 \mathrm{~mm}$; width $1.15 \mathrm{~mm}$. Antennæ (Pl. XX, fig. 10) sevenjointed, usual; third segment $0.26 \mathrm{~mm}$. in length; hind tibia $0.81 \mathrm{~mm}$. in length; first tarsal segment $0.2 \mathrm{~mm}$. in length and distal segment about half as long.

Color rather uniformly yellow to darker, legs and antennæ paler, eyes greenish. Forewings (Pl. XX, fig. 7) of both sexes with dusky markings. Hind wings unspotted. Wing surface somewhat iridescent. Adults seem to occur promiscuously among the pupæ, more or less covered by the waxy secretion of the immature stages.

Type.-No. 14774, U. S. National Museum. Described from abundant material of infested foliage and eggs, pupæ, and adults in balsam mounts.

\section{Aleurodicus ornatus Cockerell.}

(Pl. XXII, figs. 1-4.)

Aleurodicus ornatus Cockerell, Ent. Mo. Mag., vol. 29, p. 105 (1893).

We know this species only from the type material in the U.S. National Museum (type No. 14773).

\section{ORIGINAL DESCRIPTION.}

The imago, from head to the tip of the wings, measures somewhat over $2 \mathrm{~mm}$., and structurally agrees so well with the two known species of the genus, that I should not have ventured to bring it forward as new, were it not for the beautiful grey markings of the narrower upper wings. These markings, which distinguish the insect at a glance, consist of four broad, transverse gray bands, and a longitudinal band running from the outermost to the margin a little 
below the apex. On the upper half of the wing (i. e. above the central nervure) the bands are nearly straight and about equidistant, but they mostly enlarge about the middle of the wing. the third and fourth being joined by the inward prolongation of the longitudinal band. The third band is interrupted below its middle, and its lower part is joined to the second band, of which it appears an oblique branch. The true prolongation of the second band bends obliquely inwards, and is joined at one point to the first band. The second band is also joined to the first by a thin process in the region of the central nervure. For the rest, the insect is white, with the abdomen slightly yellowish. The larva is grey, with white secretion. The antennæ, legs, venation, glands of larra, etc.. seem to be practically as in A. anonce, and need not, therefore, be described.

\section{DESCRIPTIVE REMARKS.}

Pupa case.-Elliptical, about $1 \mathrm{~mm}$. long by $0.84 \mathrm{~mm}$. wide. Color under microscope yellow, darker centrally. Margin of case lightly crenulate. Dorsum little elevated, segments distinct (Pl. XXII, fig. 1). Just within margin of case all around is a series of wax pores, resembling somewhat in structure the compound wax pore, and secreting long slender wax rods (Pl. XXII, fig. 4). On caudal margin of case are two pairs of spines, and just within margin all around is a series of spines, the exact number of which can not be determined on account of the imperfect condition of the single pupa case in the type material. There are four pairs of the usual compound wax pores on abdomen and a pair on cephalic end of case (Pl. XXII, fig. 3).

Vasiform orifice broader than long, subcordate; operculum short, twice as broad as long. Lingula protruded and very long $(0.15 \mathrm{~mm}$. from base to tip), spatulate, with two pairs of strong spines at caudal end. The unusually large lingula resembles that of dugesii, though it is not dark in color as in that species (Pl. XXII, fig. 2).

Adult female.-Length of forewing about $2 \mathrm{~mm}$.; width about 1 $\mathrm{mm}$. Body reddish brown. Eyes reniform, plumbeous. Length of fore tibia $0.46 \mathrm{~mm}$. Length of fore tarsus $0.27 \mathrm{~mm}$., the segments subequal in length. Wings banded with dusky, as shown in Plate XXII, figure 5, and about as described by Prof. Cockerell.

\section{Aleurodicus pulvinatus (Maskell).}

(Pl. XXII, figs. 6-9.)

Aleurodes pulvinata Maskell, Trans. New Zealand Inst., vol. 28, p. 439 (1895).

In the Maskell collection of Aleyrodidx loaned to the Bureau of Entomology by the New Zealand Institute are two examples of the pupa case of this species, in balsam slide mounts. This insect has in general the type of case of cocois, but presents distinctive differences. While originally described as an Aleyrodes by Maskell, its resemblance in structure to Aleurodicus was recognized by the describer, 


\section{and it was later referred to this genus by Cockerell. The original} description and remarks by Maskell follow:

Larva not observed.

Pupa-case dark orange, with two broad lateral longitudinal bands of darkbrown, which do not touch the margin, and which denote the inclosed insect. Form roundly elliptical, the cephalic extremity sometimes slightly depressed; dorsum slightly convex; abdominal segments moderately distinct. Length about $1 / 20$ in. The dorsum bears, some distance within the margin, a series of twenty-two tubercular pores, glands or spinneret orifices. Of these, four on the extreme cephalic region are small, with simple circular orifices; the next two (one on each side), on a level with the rostrum, are large and conspicuous, consisting of a cylindrical tube with wide circular orifice; the next four (two on each side) on the median thoracic region are rather small, but larger than the anterior cephalic ones and have circular multiocular orifices; the next eight (four on each side) on the abdominal region are similar to two large ones near the rostrum; the last four (two on each side) near the abdominal extremity are about equal in size to the four on the cephalic region, and are simple. The margin is very finely striated, but not crenulated; and for some distance within it the dorsum is covered with great numbers of rery small circular spinneret orifices, but these do not extend to the median dorsal regions. There is no fringe, properly speaking, but all the organs just described produce secretion as noticed presently. Vasiform orifice rather broader than long, the anterior edge slightly concave, the posterior edge broadly convex; operculum small, corering about one-third of the orifice, with both edges concare, the anterior very deeply, the posterior less, depressed; lingula very long, extending some distance from the orifice, roundly conical, with two rather long setæ near its end.

The spinneret tubes and orifices above mentioned secrete a large quantity of snow-white waxy threads closely felted, and also, scattered amongst these, several long straight glassy rods, which are very brittle; these rods, when closely examined, are seen to be very delicately fluted. The threads appear to be produced from the very numerous minute spinnerets, and the rods from the rows of larger tubes. It results from the absence of small spinnerets on the median dorsal regions that the pupa case in those parts is uncovered; consequently, it appears as if lying on a thick ring or cushion of cotton, from which fact $I$ have derived its specific name.

On turning over the pupa case and dissolving the waxy matter, the rudimentary feet and antennæ are clearly visible; the feet are thick and short, the antennæ rather long, slender, and in the latest stage numerously ringed.

Adult form unknown; but from the appearance of the rudimentary wings in a late pupa examined, which was almost on the point of emerging when it died, I believe that the fore-wings will be dark and banded with dark-brown, or perhaps black.

Hab. In Trinidad, West Indies. My specimens were sent by Mr. F. W. Urich. I think the plant is Jatropha sp.

It has been necessary to be particular in describing and figuring the details of spinnerets, etc., in this species, on account of its similarity in some respects to three West Indian insects: Aleurodicus anonce, Douglas and Morgan; $A$. cocois, Curtis, and A. ornatus, Cockerell. I have already, in my introductory remarks, mentioned that these and other authors employ frequently the term "larva" to denote indiscriminately what I take to be both the larral and the pupal states. Now, first, as to color: the "larva" of $A$. anonce is said to be "ochreous," that of A. cocois (as far as I can make out) is similar; that of 
A. ornatus is "grey." No author mentions dark longitudinal brown bands, such as those which are so conspicuous in A.pulvinata. What is much more important, in $A$. anonce Mr. Morgan gives fourteen "lateral infundibuliform compound spinnerets" and "secreting glands." A. cocois (ap. Riley and Howard) has also fourteen; $A$. ornatus has glands "practically as in $A$. anone; " but in A. pulvinata there are twenty-two of these organs. No author mentions minute dorsal spinnerets within the margin, such as those which are so extremely numerous in A. pulvinata; yet, as these appear to be certainly the producers of the ring of waxy threads, they are of importance. As regards the rasiform orifice and lingula, I find those of $A$. anone (which Mr. Morgan curiously terms the anus. colon, and ilium") and those of $A$. cocois not greatly dissimilar: in fact, they may be said to be practically identical. These organs are not mentioned for $A$. ornatus. In the figure $41 \mathrm{~B}$ of A. cocois (Ins. Life, 1593, p. 314) the lingula of the adult female is shown as protruding considerably from the abdomen; probably this will also be the case in A. pulvinata.

I believe that the wings of $A$. pulvinata will be not far removed from the darkly banded ones of $A$. ornatus, but in the face of the statement that the "larva" of that species is "grey," and in the absence of any further information, I shall not at present so identify the insect, nor shall I yet relegate it to the genus Aleurodicus.

DESCRIPTIVE REMARKS.

Pupa case.-Size $1.33 \mathrm{~mm}$. long by $1.15 \mathrm{~mm}$. wide; very roundly elliptical, but little convex (Pl. XXII, fig. 6). As described above, there are along each side two broad and irregular longitudinal bands of dark-brown color in the derm, and there is a light yellow or semitransparent longitudinal band along the central dorsal area. We are unable to verify Maskell's description in reference to the "twentytwo tubercular pores, glands, or spinneret orifices." It seems clear that the tubercles of certain spines were mistaken for wax pores. On the type specimens the tubercular spines are to be made out with considerable certainty, a series all around case, well within the margin, 10 or 11 on each side, as shown in the figure. There is also a pair of spines on caudal end of case. There are seven pairs of compound wax pores (Pl. XXII, fig. 8), one on cephalic end, and on the abdomen are four pairs of large and two pairs of small pores. There is a pair of spines just cephalad of the vasiform orifice, and three pairs on the thoracic region toward the median line. Also on the thorax are two pairs of stellate, transparent spots. The margin of case is entire. Just within margin all around is a closely set row of minute tubular wax pores resembling those in cocois. Also as in cocois, there is on the submarginal area all around a broad band of minute simple wax pores.

Vasiform orifice (Pl. XXII, fig. 7) broadly cordate, broader than long, cephalic margin straight. Operculum considerably broader than long, anterior margin straight, sides rounded, caudal margin concave and minutely setose, bearing distally two pairs of spines. 

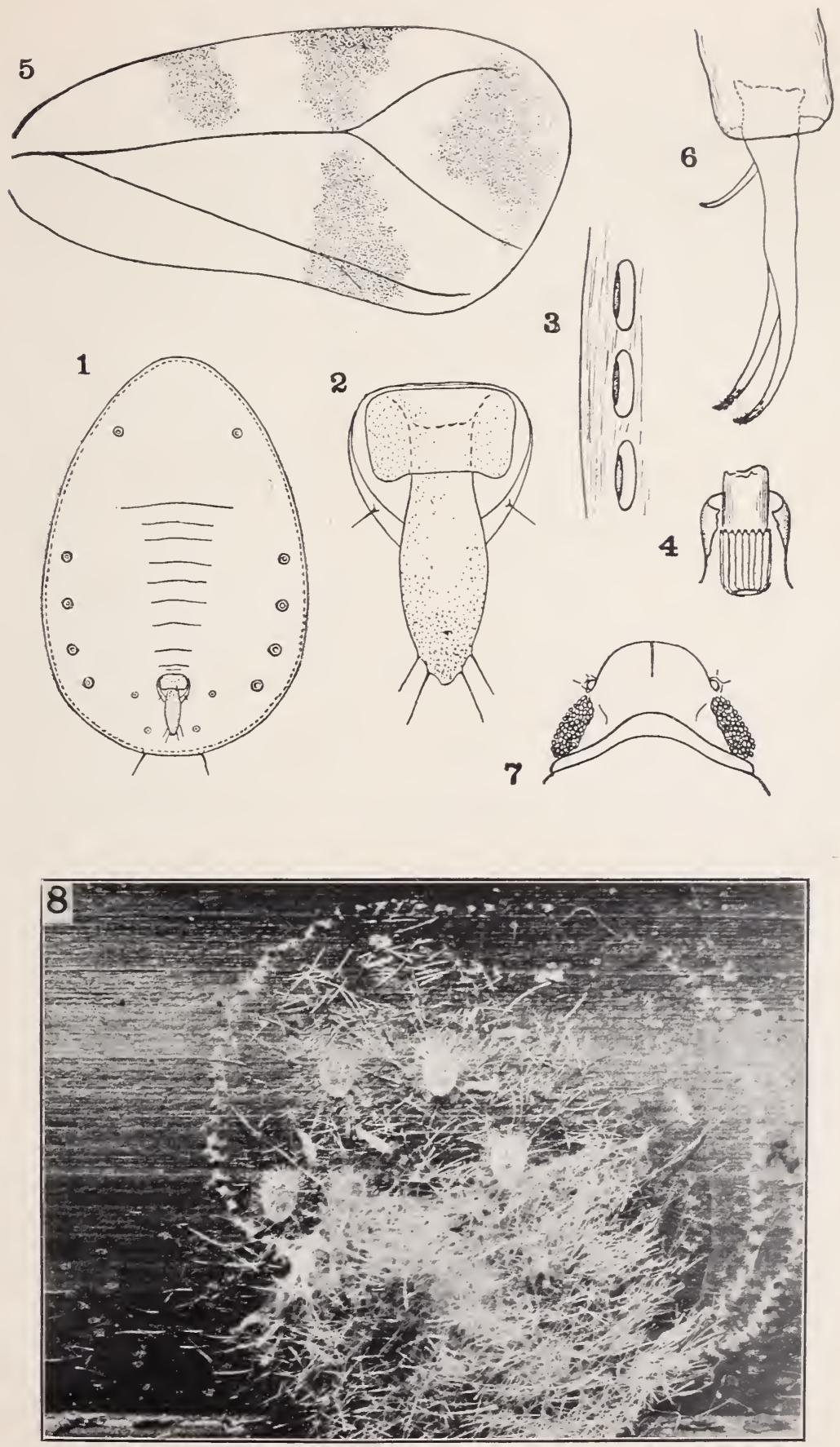

ALEURODICUS TRINIDADENSIS.

Fig. 1.-Pupacase, Fig.2.-Vasiform orifice. Fig. 3.-Margin of pupacase. Fig. 4.Compound wax pore. Fig. 5.-Forewing. Fig. 6.-Claspers of male. Fig. 7.-Head of adult. Fig. 8.-Pupæ on leaf, showing waxy secretion of pupæ and trails of wax left by adults. ( $\mathrm{F}$ ig. $1-\bar{\tau}$, original; fig. $\mathrm{S}$, from Urich.) 


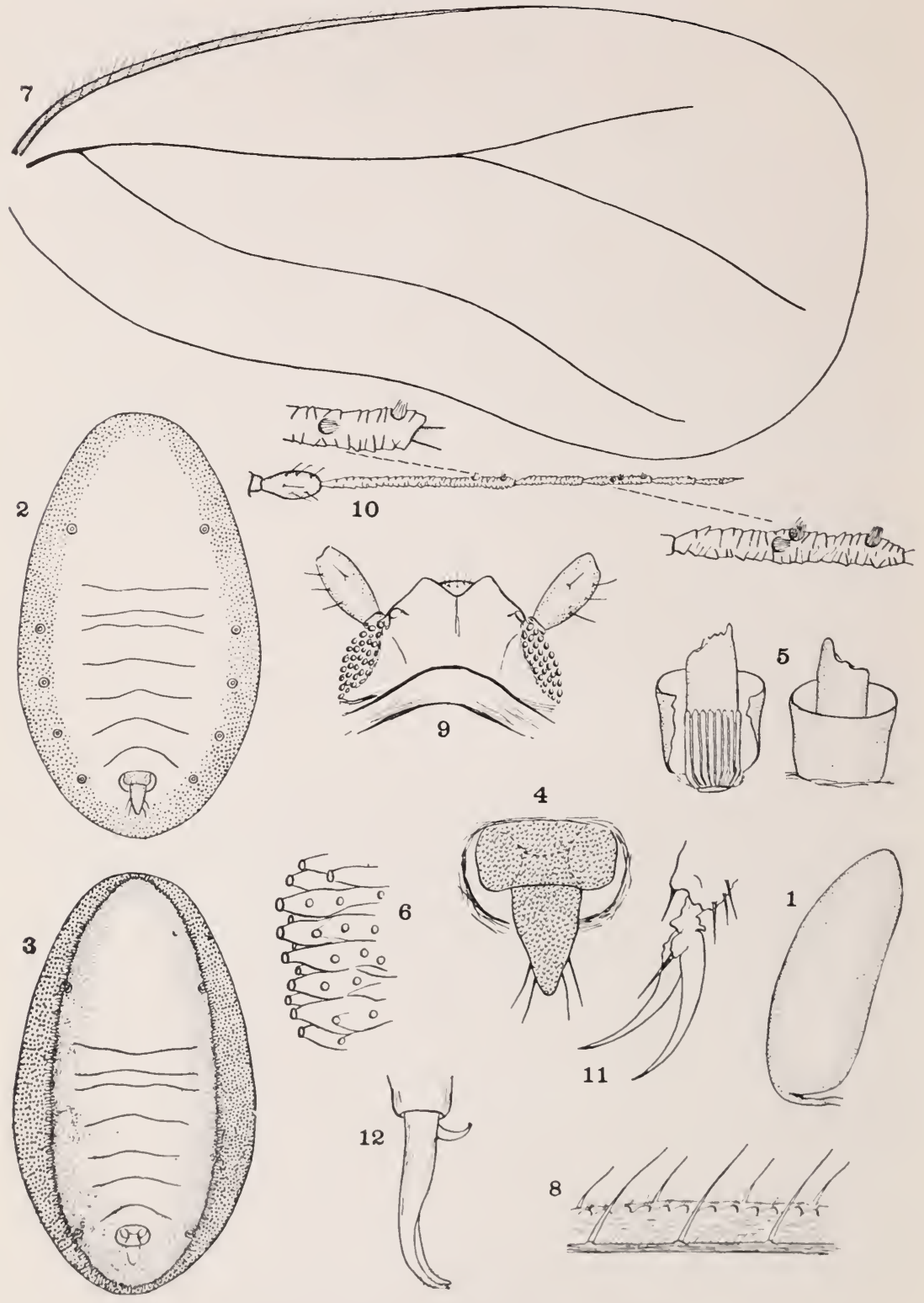

ALEURODICUS (LECANOIDEUS) GIGANTEUS.

Fig. 1.- Eigg. Fig. 2.- l’upa case, dorsal view. Fig. 3. - Pupa case, ventral view. Fig. 4.-Yasiform orifice of pupa cuse, Fig. 5.-Componnd pore of pupal cise. Fig. 6.-Margin of pupa case. Jig. - - Forewing of adult. Fig. s.- ('ostal margiu of forewing. Fig. 9.-lleat of adult. lig. 10.- Intenna of alult. Fig. 11.-Foot of adnlt. Fig. 12.-Male genitalia. (Original.) 


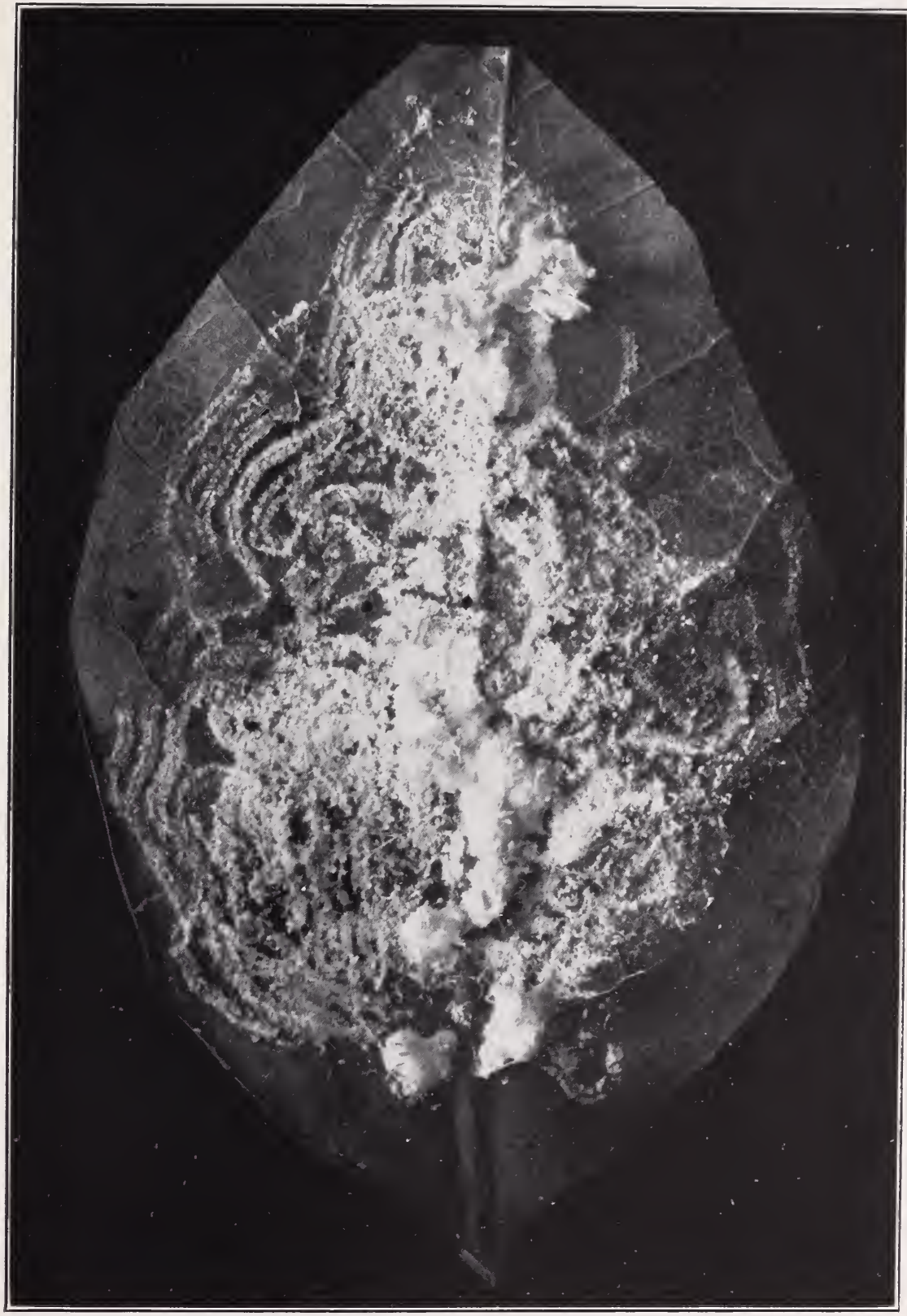

Aleurodicus (Lecanoideus) giganteus. Leaf, Showing Waxy Secretion of Pupe AND TRaILS OF SECRETION LEFT BY AdULTS. (ORIGINAL.) 

Aleurodicus trinidadensis n. sp.

(Pl. XXIII, figs. 1-8.)

Specimens of this insect were received from Dr. F. W. Urich, Trinidad, on March 27, 1912. The pupx are similar to those of dugesii and ornatus in that they possess a very prominent lingula. 'The adults, however, are nearer to those of cocois.

DESCRIPTION.

Pupa (Pl. XXIII, fig. 1).-Color yellowish; empty case transparent, with very faint shadings around the base of some of the compound wax pores. These pores are arranged in seven pairs, one thoracic pair and six abdominal. The two caudal pairs are reducer. The spinnerets of the compound pores (Pl. XXIII, fig. 4) are extended into rods which are about half the length of the outer cup and the central process protrudes some distance from the opening of the pore. Margin (Pl. XXIII, fig. 3) entire and just within it, all around, a series of disc-like pores. Vasiform orifice (Pl. XXIII, fig: 2) subcordate in outline, the anterior margin straight, and the laterocaudal "fold" armed on each side with a bristle. Operculum rectangular, transverse, with the caudal margin slightly indented. Lingula very large and exserted, the distance from the anterior margin of the orifice to the tip of the lingula being about twice the longest diameter of the operculum. Both lingula and operculum are setose and the former is armed with four spines. Shape elliptical, broadest slightly caudad of middle. Size $1.36 \mathrm{~mm}$. by $0.928 \mathrm{~mm}$. On the leaf the waxy secretion does not present a thick mass, but is composed of a large number of distinct waxen rods, many of which become broken (Pl. XXIII, fig. 8). The marginal fringe is composed of a series of fine distinct waxen rods.

Adult.-Color yellowish, the abdomen and appendages of some specimens tinged with reddish. Eyes dark brown. Forewings marked with four dusky areas as illustrated in Plate XXIII, figure 5. The intensity of these markings varies considerably and in some specimens they are hardly noticeable. In others the two dusky areas on either side of the radial fork become united into a band. Hind wings unmarked, excepting a shaded margin sometimes present along the proximal portion of veins. Vertex (Pl. XXIII, fig. 7) rounded; claspers of the male (Pl. XXIII, fig. 6) long and narrow, with the tips sometimes dusky. Penis short, slightly curved.

Forewing 1.9 by $0.96 \mathrm{~mm}$; ; of female $1.6-2.08 \mathrm{~mm}$.; of male 2.16 $\mathrm{mm}$.; claspers from base to tip $0.64 \mathrm{~mm}$. ; last abdominal segment 0.56 $\mathrm{mm}$.; penis $0.288 \mathrm{~mm}$.

Type.-No. 14777, U. S. National Museum. Described from specimens in balsam and dry specimens on infested foliage. Taken on coconut. 
Subgenus LECANOIDEUS n. subgen.

Insects with the characters of the subgenus Aleurodicus, excepting that the vertex of the adult is bilobed and the lateral margin of the pupa case is deflexed, curving under the ventral surface. The pupæ are devoid of the reduced compound pores near the rasiform orifice. Lingula of pupa usually exserted; that of adult narrow and included.

Type, giganteus n. sp.

Species of Subgenus Iecanoideus.

A. Pupa case large and broad, with the anterior pair of compound pores near cephalic extremity mirabilis.

B. Pupa case elongate, with the anterior pair of compound nores a considerable distance from the cephalic extremity. giganteus.

\section{Aleurodicus (Lecanoideus) giganteus n. sp.}

(Pl. XXIV, figs. 1-12; Pl. XXY.)

This aleyrodid was collected by Mr. Albert Koebele at Pernambuco, Brazil, December 28, 1882. The host was not stated by Mr. Koebele, but appears to have been a species of Ficus. As stated with reference to $A$. neglectus, the present species was also carried in the Bureau of Entomology collection as anonce Douglas, and this latter was thus erroneously listed from Pernambuco, Brazil. This is the largest species of the genus thus far recorded, although a much larger member of the family, Udamoselis pigmentaria ( $p 25$ ) from South America, has been described by Enderlein, ${ }^{18}$ with a wing length of $5.5 \mathrm{~mm}$. and a body length of $7 \mathrm{~mm}$.

\section{DESCRIPTION.}

Egg.-Elongate, about $0.4 \mathrm{~mm}$. long. Stalk short; eggs lying prostrate on leaf, on which they are scattered promiscuously; brownish in color and without markings (Pl. XXIV, fig. 1).

Pupa case.-Length from 1.5 to $1.85 \mathrm{~mm}$. Width 0.9 to $1 \mathrm{~mm}$; elongate, somewhat narrowed at each end. Convex, the sides deflexed in mature specimens, resembling a lecanium scale (Pl. XXIV, figs. 2,3). Pupæ are covered by a very abundant secretion of white wax, of a generally flocculent appearance (Pl. XXV). Examined more particularly, there will be observed a group of vertical columns considerably higher than the case is wide, from the abdominal region of the dorsum, very compact at the base, but separating more or less into separate bundles distally. This secretion appears to arise from the abdominal segments, extending completely across the dorsum, from the compound wax pores on each side. Also in this columnar type of secretion are found the glassy wax rods from the compound wax pores which in this species are comparatively slender and short. 
There is also a copious secretion of minute cottony wax threads, from a broad submarginal zone or band of small simple pores completely around the case. From the margin or edge of the case there is a secretion from the tubular wax pores (Pl. XXIV, fig. 6) which extends downward, more or less, under the pupa case in the form of an amorphous wax plate. The color is brownish to very dark brown. Some specimens, however, have a distinctly reddish color, though such individuals are comparatively few. The empty case is very light brown, without distinctive color markings.

The dorsum and margin of case are without spines. On each side of the abdominal region are four compound wax pores (Pl. XXIV, fig. 5) and a pair of similar though smaller pores occurs on the cephalic end of case. The two pairs of small compound pores present on the caudal end of the case, in many members of the genus, are absent in this species.

Vasiform orifice (Pl. XXIV, fig. 4) subcordate, considerably wider than long. Operculum about twice as wide as long, the basal corners rounded, the caudal margin somewhat concave.

Lingula large, exserted, spatulate in shape, bearing toward distal end two pairs of spines. On ventral surface, legs and antennæ very evident; basal segment of leg large, subglobose. Distal segment of leg longer than basal, finger-like, ending in a single curved claw.

Adult female.-Length from head to tip of abdomen about 2.75 $\mathrm{mm}$.; length of forewing 3.50 to $3.75 \mathrm{~mm}$.; width 1.70 to $1.75 \mathrm{~mm}$. (Pl. XXIV, figs. 7 and 8) ; length of hind tibia about $1.23 \mathrm{~mm}$; length of basal segment of tarsus $0.32 \mathrm{~mm}$.; length of distal segment $0.16 \mathrm{~mm}$.

Color of body and head light brownish, the legs and antennæ paler; wings white, without markings, more or less, dusted with powdery wax. Ventral surface of body of the insect with light flocculent wax apparently secreted from the abdomen. Some leares show paths or trails of white wax, evidently made by the adults during the course of their movements (see Pl. XXV). Eyes of the usual constricted form. Antennæ about $1 \mathrm{~mm}$. in length; segments I and II about equal in length to segment VI; segments VI and VII subequal; segment III about one-sixth shorter than segments IV to VII, inclusive ( $\mathrm{Pl}$. XXIV, figs. 9-12).

Male.-Having the general appearance of the female. Genital valves long and slender, penis short and curved near distal end.

Type--No. 14767, U. S. National Museum. Described from abundant material of eggs and pupæ on leaves, and adults on card points, and all of these stages in balsam mounts. 


\section{Aleurodicus (Lecanoideus) mirabilis Cockerell.}

(Pl. XXVI, figs. 1-5; Pl. XXIX, fig. 1.)

Alcurodicus mirabilis Cockerell, Psyche, vol. 8, p. 225 (189S) ; idem, p. 360 (1899).

\section{ORIGINAL DESCRIPTION.}

Pupa (late larva?) $1 \frac{2}{3} \mathrm{~mm}$. long, after boiling transparent and colorless, except some brown stains in the thoracic region. Mouth-parts distinct and well formed; rostral loop short; legs present, very stout, with small, hooked claws. Form oblong, quite elongate, with a border densely dotted with round glands; anteriorly this border is very narrow, and at the extreme hind end it ceases, but all along the sides it is extremely broad. The cephalic portion of the insect, the hind end, and the lateral margins within the border, are also densely dotted with glands. Abdomen distinctly segmented, but the segmentation does not extend to the border. On each side of the abdomen are four curious large glandular processes, of the type of those in A. holmesii Mask. Lingula trowelshaped, extending considerably beyond the broad operculum; at each side of the base of the lingula is an angular prominence. The general type of these parts is that of A. pulvinata Mask., but while the lingula is equally long, it is in our insect gently bowed out at the sides; and the two bristles at the end of the lingula in mirabilis are not nearly so long as in pulvinata.

Externally the insect appears as a large mass (5 to $10 \mathrm{~mm}$. long) of snowwhite cottony tufts, irregularly disposed, from the midst of which spring many very long curved white threads. The pupa itself is entirely covered.

Hab.-Boca del Usumacinta, Tabasco, Mexico, July 8, 1897, on "Laurel," which is not our plant of that name ('Townsend) Div. Ent. 7984. 'This remarkable insect resembles Aleurodicus in several respects; when all its stages are known, it will probably be referred to a new genus.

Prof. C. H. 'T. 'Townsend found this species in quantity at Minatitlan, Mexico, April 25, 1898, on the underside of Anona leaves. Fortunately, he secured a single $\hat{o}$ adult, which shows that the insect belongs to Aleurodicus. The anterior wings are slightly over $2 \mathrm{~mm}$. long and about $1 \frac{1}{3} \mathrm{~mm}$. broad; white, with two very pale gray bands; the first crossing the wing just before the fork of the median vein, but interrupted for a space below the vein; the second a dilute transverse cloud not far from the apex of the wing. Body about $2 \mathrm{~mm}$. long, exclusive of the forceps, which are about $\frac{8}{4} \mathrm{~mm}$. Color of body and legs very pale yellow; base of abdomen white; thorax between wings light orange. Antennie orange at the middle; eyes pale greenish, not divided. Easily known from A. anone Morgan, by the markings on the wiugs of the adult, and the lingula longer than the operculum in the pupa.

\section{Type.-No. 14770, U. S. National Museum.}

\section{DESCRIP'IVE REMARKS.}

This insect in structure of pupa case closely resembles giganteus. The dotted border to which reference is made by Prof. Cockerell is really the deflexed portion of case, seen through the derm above, the margin resembling a suture in the derm (Pl. XXVI, figs. 1, 2). In general shape the case resembles a lecanium scale. There are four pairs of the usual compound wax pores on the abdomen, and a similar pair on the cephalic end (Pl. XXVI, fig. 4). 'The true margin is 

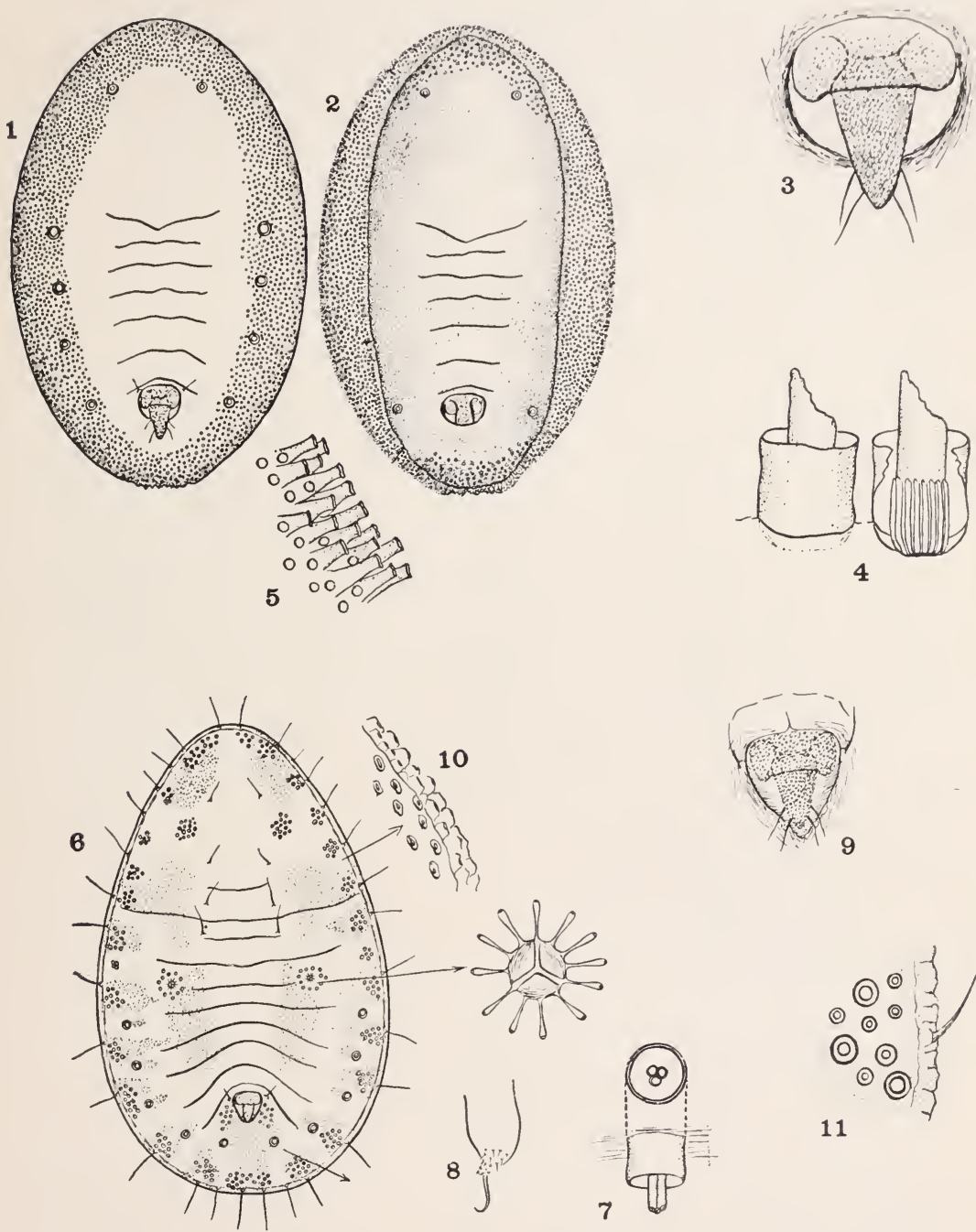

\section{ALEURodicus (LeCANOIdEUS) MIRABILIS AND ALEURodicus (METALEUROdicus) ALTISSIMUS.}

Aleurodicus (Lecanoideus) mirabilis: Fig. 1.-Pupa case, dorsal view. Fig. 2.-Pupa case, ventral view. Fig. 3.-Vasiform orifice of pupa ease. Fig. 4.-Compound wax pores of pupa case. Fig. 5.-Margin of ease. Aleurodicus (1fetaleurodicus) altissimus: Fig. 6.Pupa case. Fig. 7.-Compound wax pore of pupa case. Fig. 8.-Foot of pupa. Fig. 9.-Vasiform orifice of pupa case. Fig. 10.-Margin of pupa case. Fig. 11.-Marginal pore patch. (Original.) 


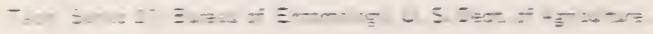

$P_{-1}=\times \times V I$.

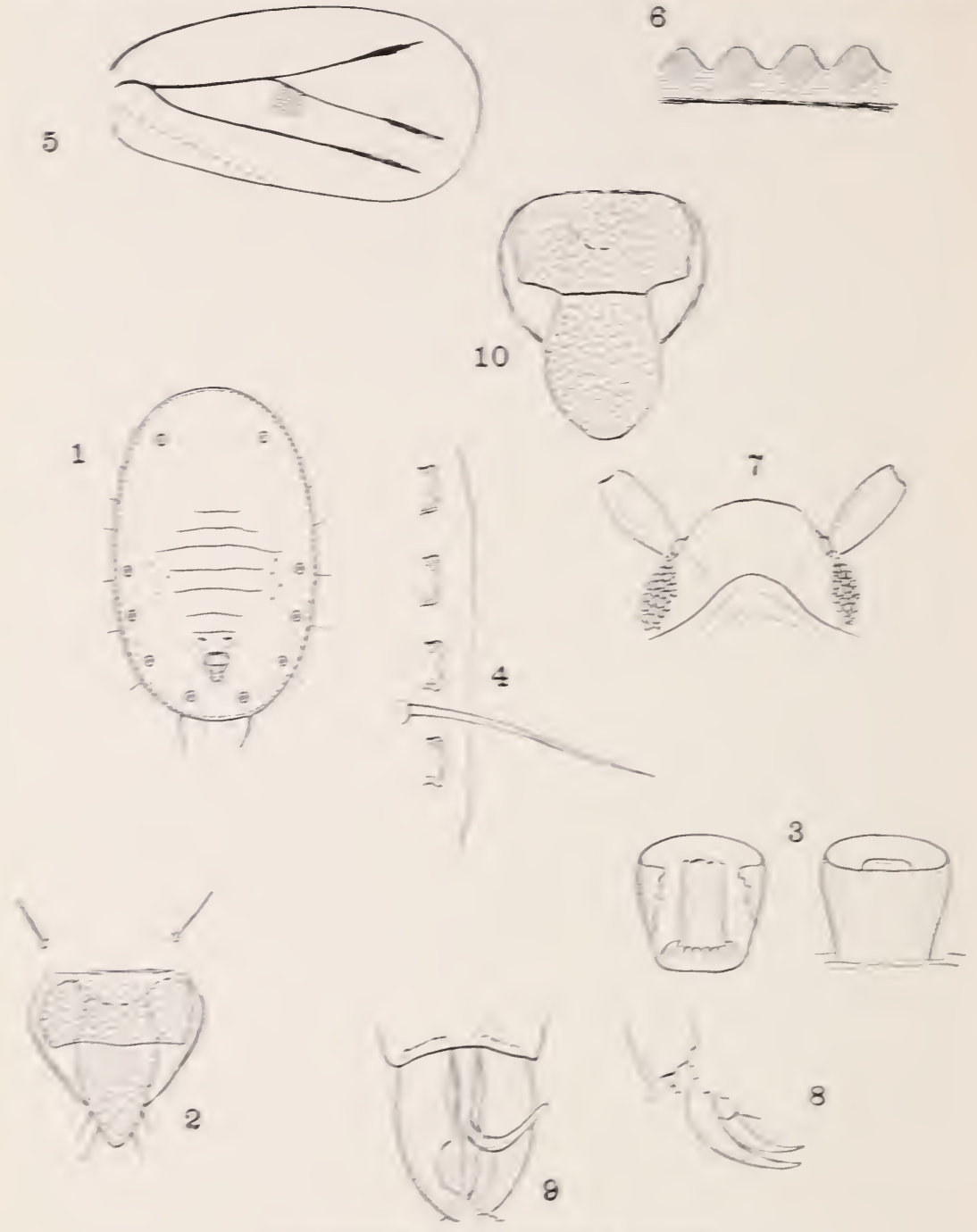

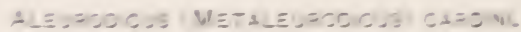

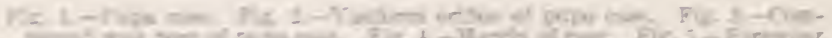

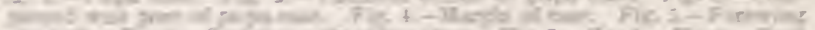

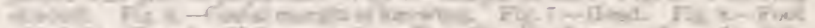

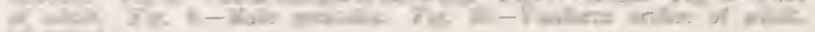


Tec Se $=527$ Bureau of Entomo ogy U S Dep: Ag cu tura

PLATE XXVIII.
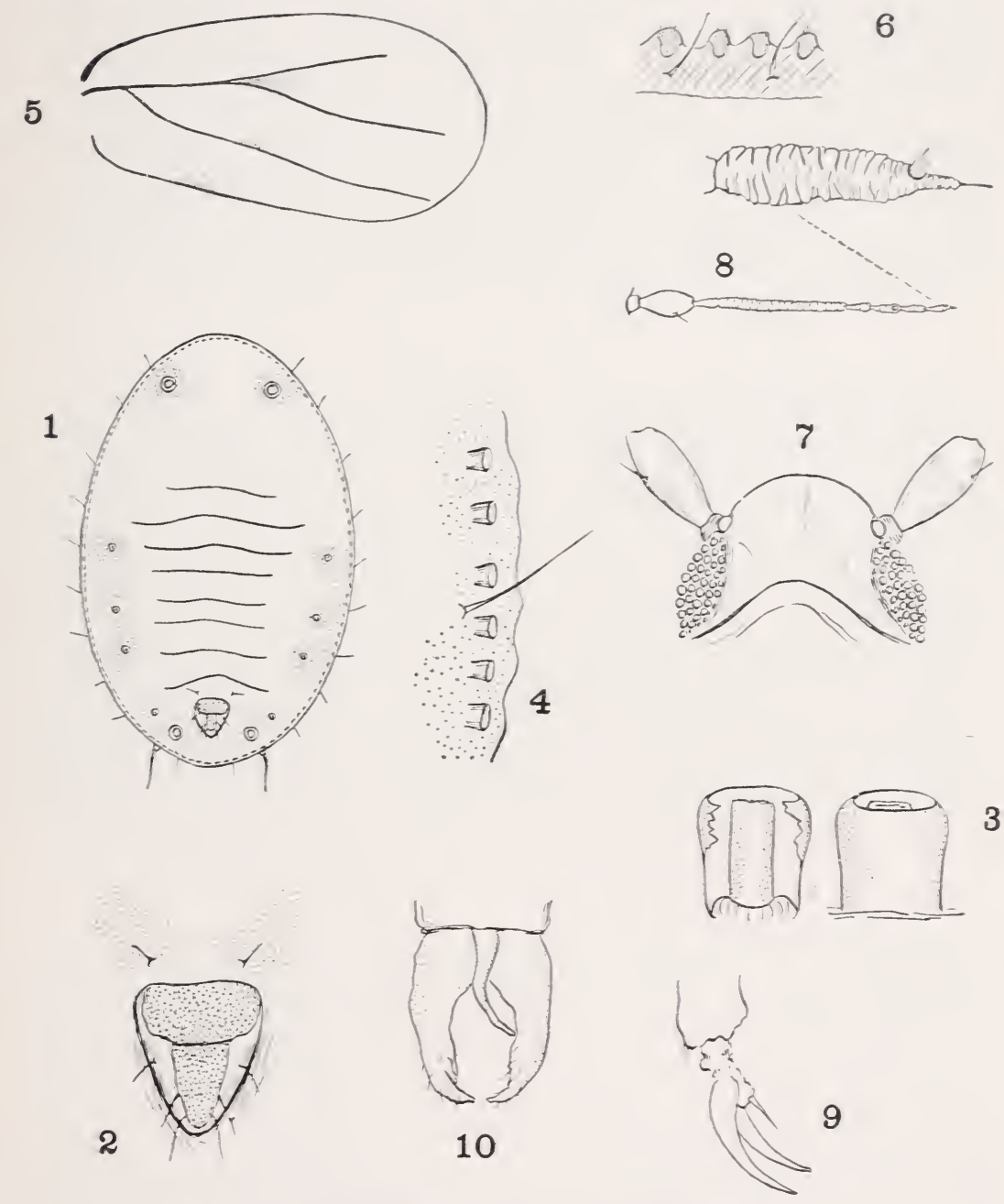

ALEURODICUS I METALEURODICUS MINIMUS.

Fig. 1.-Pupa case. Fig. 2.-Tasiform orifice of pupa case. Fig. 3.-Compound wax pores of pupa case. Fig. 4.-Margin of pupa case. Fig. 5.-Forewing of adult. Fig. 6.-Costal maryin of forewing. Fig. 7.-Head of adult. Fig. S.-Antenna. Fig. 9.-Foot of adult, Fig. 10.-Male genitalia. (Original.) 


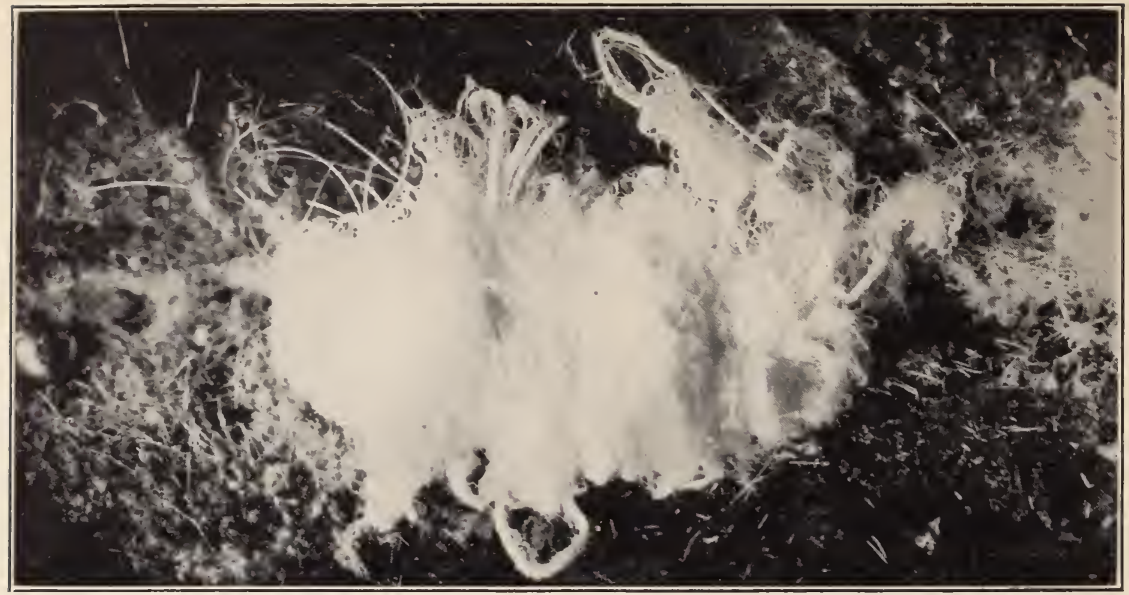

Fig. 1.-Aleurodicus (Lecanoideus) mirabilis: Pupe on Leaf, Showing Waxy SECRETION. (ORIGINAL.)

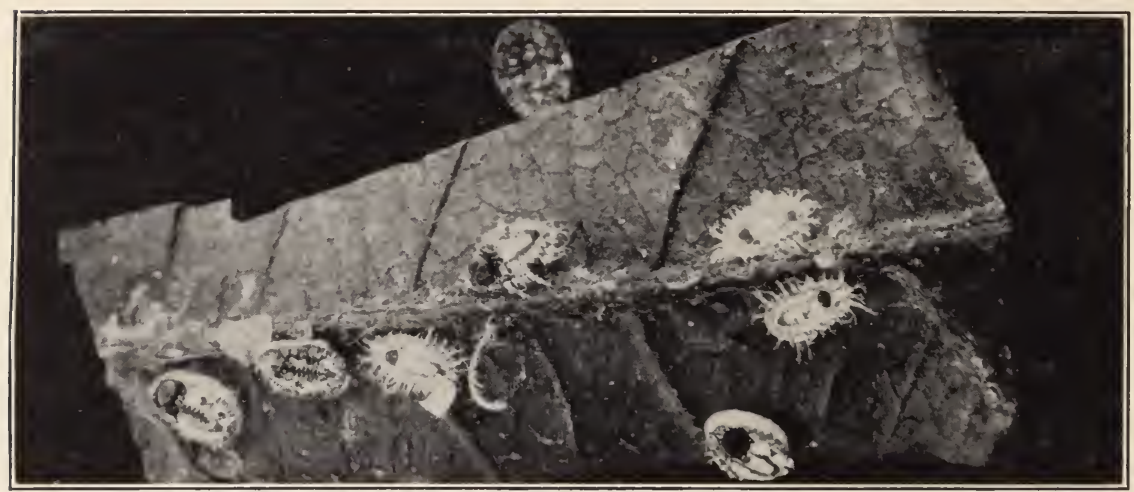

Fig. 2.-Aleurodicus (Metaleurodicus) altissimus: Pupe on Leaf, Showing Waxy SECRETION. (ORIGINAL.)

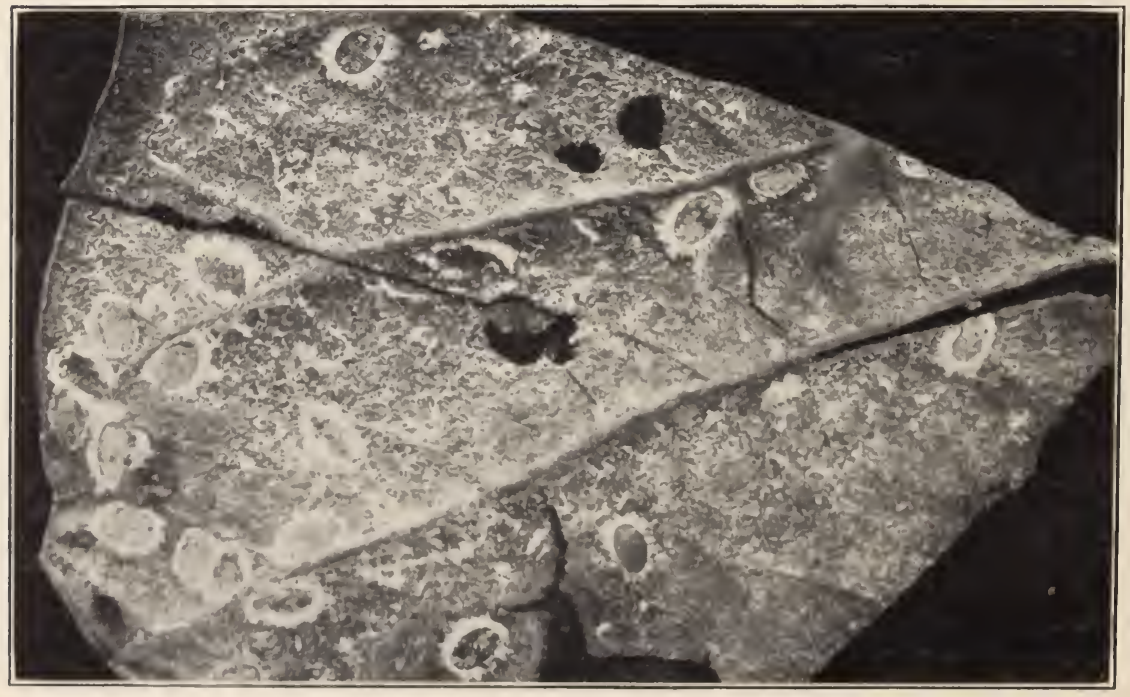

Fig. 3.-Aleurodicus (Metaleurodicus) minimus: Pupa on Leaf, Showing Waxy SECRETION. (ORIGINAL.) 
folded under the case and ends in a series of closely set, superimposed wax tubes (Pl. XXVI, fig. 5). Vasiform orifice (Pl. XXVI, fig. 3) broadly cordate, considerably wider than long. Operculum short and broad. Lingula large, protruded, arrow-shaped, with two pairs of spines, distally. On ventral surface, legs and antennæe very evident. Basal segment of legs large, subglobose; distal segment longer than basal, finger-like, ending in a single strongly curved claw; antennæe long, numerously ringed as usual.

Adult.-The adult we have not seen. It differs from giganteus in being smaller, and in the wing markings as described by Cockerell.

\section{Subgenus METALEURODICUS n. subgenus.}

Forewing with the venation of Aleurodicus, but with radius ${ }_{1}$ much longer; antennæ and feet similar to Aleurodicus; vertex rounded; claspers of male short and thick; penis rather long; pupa case with compound wax pores, but these are different from those of Aleurodicus, being of the type illustrated in Plate XXVI, figure 3 ; lingula of vasiform orifice of pupa setose, short, included, and armed with four spines; that of adult broad, large, and exserted. Size small.

Type, minimus Quaintance.

\section{Species of Subgenus Metaleurodicus.}

A. Abdomen of pupa case with five pairs of equal sized compound pores and on cephalo-median portion of abdomen a stellate structure surrounded by simple pores altissimus.

B. Abdomen of pupa case with five pairs of compound pores of which the caudal are the largest"; forewing with a dark macula within the radial fork minimus.

C. Abdomen of pupa case with four pairs of compound pores; forewing with a dark macula below the radial sector _cardini.

\section{Aleurodicus (MIetaleurodicus) altissimus (Quaintance).}

(P1. XXVI, figs. 6-11; Pl. XXIX, fig. 2.)

Aleurodes altissimu Quaintance, Tech. Ser. 8, Div. Ent., U. S. Dept. Agr., p. 20, (1900).

\section{ORIGINAL DESCRIPTION.}

Larva.-Size about 0.89 by $0.52 \mathrm{~mm}$. ; yellowish white. A series all around of about 30 setæ. On dorsum are 5 pairs of moderately developed setæ, a pair on cephalic segment, a pair on each of the thoracic segments, and a pair at vasiform orifice. Margin of case slightly crenulated. On the dorsum a few pores may occur somewhat promiscuously, and there are a few groups of pores around the margin. This stage in many respects approaches quite close in structure to the pupa-case.

Pupa-case.-Size about 1.79 by $1.26 \mathrm{~mm}$. ; subovate, narrowed cephalad. Color of young pupæ, yellowish to white, and usually without other coloration. In 
more mature examples the color may vary from whitish to those more or less mottled with brownish, with extreme cases almost uniform brownish black, though in these latter cases such examples have plainly been parasitized, and this color may have resulted from this fact. Typically, this brownish coloration occurs in dashes, from the outer margin inward, varying distances, and more or less radially. Along the dorsi-meson there is a more or less clear longitudinal central stripe, with an interrupted stripe of dark brown on each side, these latter varying considerably in extent and distinctness. In well-marked specimens the radial wedge-shaped dashes may extend quite into these subdorsal bands of dark brown.

Pupa-case, when young, with moderately rounded keel, otherwise flat; at length becoming somewhat convex, and raised on an unusually high vertical fringe of white wax. There is no lateral fringe, but just within the margin all around there is a series of groups of waxen rods. These rods arise from groups of from usually 22 to 26 circular pores. Each bundle of rods is surrounded with a rather short cylinder of wax, forming a sheath at base. Individually, the rods are rather small, glistening white, and inclined to curl at tip. These wax bundles vary considerably in length, but are, as a whole, short, curling outward and downward from the case. Along central dorsal region is a broad and somewhat matted secretion of wax extending from vasiform orifice to cephalic end and covering the rounded keel. On each side of this central dorsil secretion is a curved and narrower secretion extending from just laterad of vasiform orifice to cephalic end. These three dorsal lines of wax may be much interrupted transversely, particularly in younger examples, but in older cases each is usually continuous.

There is a very narrow marginal rim and the margin of case is minutely crenulated. Just within the margin all around is a series of rather long and slender tubercled setre, about 30 in all, or 15 on each side. The pores of the submarginal groups are rather small, simple, and circular. These may vary considerably in number in the different groups, and an occasional pore occurs outside of group. These groups of pores are usually in the brownish coloration extending in from the margin. There is usually a group of very small pores on each side of vasiform orifice, and a very pretty group on each side of the second abdominal segment. This consists of an irregular circle of small pores with a central rotate figure. The usual series of brownish colored compound pores with cylindrical rim and central rod are present, though comparatively small. On caudal end 4 of these pores occur in almost a transverse row, caudad of orifice, and from this 3 extend cephalad on each side to about the fourth abdominal segment.

Vasiform orifice cordate, about as wide as long. Operculum subrectangular, about twice as wide as long. Lingula large, broad, spatulate shaped, extending quite to caudal margin of orifice and bearing the usual two pairs of subterminal setre. Margin of orifice extended upward all round, but more pronounced caudad, into a thin and somewhat futed rim. Operculum and lingula minutely setose or punctured. On the ventral surface the reduced legs and antennix are quite distinct.

Adults unknown.

When the adult is discovered it will very likely prove to be an Aleurodicus.

Collected by $\mathrm{Mr}$. C. H. 'T. 'Townsend, July, 1S97, at San Francisco del Peal, Tabasco, Mexico, on a plant called "Palo de Gusano." Div. Eut., No. 7979. Described from numerous pupa cases.

Type.-No. 14763, U. S. National Museum. 


\section{Aleurodicus (Metaleurodicus) cardini Back.}

(P1. XXVII, figs. 1-10.)

Aleurodicus cardini Back, Can. Ent., vol. 44, pp. 14S-151 (1912).

\section{Dr. Back's original description is as follows:}

Egg.-About $0.26 \mathrm{~mm}$. long, width about $0.076 \mathrm{~mm}$. Elongate oval, uniformly pale yellowish, unmarked. Pedicel short; egg lying prone on leaf, often entirely surrounded and concealed by fluffy waxen secretions of the adult. Eggs laid without regard to arrangement on leaf.

Laria.-Crawling first instar. Length about $0.319 \mathrm{~mm}$., width about 0.12 mm. Elongate oval, pale yellowish white in color without darker markings or waxen secretions. Thirteen pairs of marginal spines, short, the posterior two pairs longer; a fourteenth pair located on venter near margin on cephalic end of case. Spine on lower side of distal third of antennæ and terminal spine of antennæ proportionately longer and more distinct than in A. citri or A. nubifera.

Pupa case.-Length about $0.94 \mathrm{~mm}$., width about $0.64 \mathrm{~mm}$. Subelliptical, elevated on a vertical marginal waxen fringe. Color yellowish to rellowish white, after emergence empty case whitish, semitransparent; parasitized specimens appear blackish either throughout or in spots. Margin entire, without pattern of any sort; near margin is a series of wax pores. On venter near margin are eighteen or twenty inconspicuous bristles seen only with high magnification; of these, three pair, one cephalic, and two caudad, are more conspicuous. On dorsum nearer the margin than center are fire pairs of round, welldefined compound pores, four pairs on abdominal segments and one pair on cephalic region. Cephalad of rasiform orifice is a pair of minute bristles. Vasiform orifice elongate cordate, about $0.09 \mathrm{~mm}$. wide at base, and about $0.1 \mathrm{~mm}$. long from base of operculum to tip of lingula; cephalic margin straight, caudal and [end] evenly rounded. Operculum subelliptical nearly one-half as long as orifice. Lingula broad, extending weil beyond caudal end of orifice, on distā fourth which usually lies beyond caudal end of orifice with two pairs of comparatively long setæ. Rudimentary legs and antennæ as usual.

From wax pores on dorsum, there may be frequently seen protruding white glistening waxen rods which frequently break off and fall about the pupæ as in $P$. persece. The dorsal surface of case usually becomes, especially towards maturity, well dusted with a thin coating of white secretions, and at times a very narrow, downwardly directed marginal fringe may be seen outside the vertical fringe.

Adult.-Length, ô, about $1.16 \mathrm{~mm}$; forewing, 우, $1.39 \mathrm{~mm}$. by $0.62 \mathrm{~mm}$.; length hind femur, $0.26 \mathrm{~mm}$. Length hind tibia, $0.35 \mathrm{~mm}$.; length hind tarsi, $0.18 \mathrm{~mm}$; length claws, $0.08 \mathrm{~mm}$; ; proportionately larger. Yellow, covered with whitish waxen secretion; eyes red, not divided, but distinctly constricted. A line extending along side of head, interrupted by upper portion of compound eye, the lateral callosities of prothorax, indistinct traces along suture of proximal segments of abdomen, and portions of vasiform orifice, all blackish. Wings beautifully iridescent, with deep violescent reflections, a small prominent round brownish spot about $0.06 \mathrm{~mm}$. in diameter on each fore and hind wing just behind the posterior distal branch of vein, usually enveloping vein but never filling the angle between veins as shown in A. mimos [minima] (Tech. Bull. 8, Div. Ent., Dept. Agric., Pl. VI, fig. 6), wings otherwise unmarked. Antennæ seven-jointed, the comparative lengths of the various segments as follows: Segments $\frac{1}{25}, \frac{2}{6}, \frac{3}{137}, \frac{4}{8}, \frac{51}{1.5}, \frac{6}{2.5}, \frac{7}{2.4}$.

$61201^{\circ}-13-6$ 
Segments 3 to 7 show usual corrugations; segment 7 with constriction on distal half at which point is borne a distinct bristle.

Habitat.-Type material collected at Havana and Santiago de las Vegas, Cuba, in November, 1910 , by the writer.

Food plant.-Guava, Psidium guajava radii.

Type.-Type material in collection of the U. S. D. A., Bureau of Entomology, and in that of the writer.

This species is really distinguished by its iridescent wing on which the spots described stand out prominently. It differs superticially from iridescens in having a spot on the hind wings and in color of pupa case; from minima it differs in having no appreciable clouding of wings other than the spots described, in shape and location of the spots, and in the pupa calse having but five instead of seren pairs of wax pores. The darkened portions of the vasiform orifice appear as a dark spot on the untreated adult. In crawling about the leaf, the female leaves behind a line of fine fluffy waxell secretion rubbed from a tuft of the same dereloping on the underside of her abdomen. Frequently her path can be distinctly followerl by the aid of these lines of secretions. In mating, the sexes head in the opposite direction, and in this respect differ from those species of Aleyrodes that have come under the observation of the writer.

This species becomes quite abundant on the guava at times, and when not parasitized becomes a nuisance. In Norember, 1910, it was calusing noticeable blackening of the foliage at Santiago de las Tegas. The species is, however, heavily parasitized by a hymenopterous parasite and the red fungus (Aschersonia aleyrodis) which the writer found generally present on affected leaves. Prof. P'atricio Cardin, for whom this species is named, sent the writer specimens in May, 1911, over $90 \%$ of which had been parasitized by a hymenopterous parasite. This is the species of white Hy figured by Cook and Horne as an undetermined aleyrodid on guava (PI. XV, fig. 41, Bull. 9. Estacion Central Agronomical de Cuba), and beyond doubt is that referred to in the Primer Informe Anual of the same station as "Guagua a mosca blanca de la guayabo." Cook and Horne (l. c., p 31), say that Aleyrodes howardi is the species referred to, but in this they are apparently mistakell, as the writer has not found howardi except rery rarely on guava. While howarli was generally present on orange trees close by, this species was found only on guava.

\section{DESCRIPTIVE REMARKS.}

Pupa case.-Form elongate oval; length $0.896 \mathrm{~mm}$.; width 0.616 $\mathrm{mm}$. Dorsum with five pairs of large compound pores with reduced spinnerets (Pl. XXVII, fig. 3). Scattered on the surface of the dorsum are also found a number of minute clear areas, resembling pores. Dorsal margin entire; just within it all around is a row of large simple wax pores (Pl. XXVII, fig. 4). On the caudal extremity, opposite the two caudal compound pores, is a pair of large hairs. Along the margin all around and apparently on the ventral surface is a row of small spines, there being about nine to a side. A pair of small seta is inserted just cephalad of the vasiform orifice. This orifice is subcordate in outline, with the cephalic margin straight. The operculum is almost rectangular in shape, with the caudal,margin wavy. The lingula is somewhat spatulate, slightly exserted, and armed with four long hairs. Both operculum and lingula are setose. 
The color is a light greenish brown.

Adult.-The adults are greenish yellow in color. The vertex is shaded on either side with dusky. The compound eyes are brownishblack and the ocelli clear and surrounded by a conspicuous Indianred area. The thorax is marked with black, which is arranged in more or less broken transverse bands, which sometimes appear as mere spots. Abdomen generally unmarked. Vasiform orifice with the operculum and lingula blackish. Forewings (Pl. XXVII, fig. 5) shaded all over with dusky, giving the wing a smoky look excepting a line representing the cubitus, which is clear, unshaded. Near their tips the veins $R_{1}, R_{s}$, and $M$ are somewhat swollen and clouded, and just at the radial fork below $R_{\mathrm{s}}$ there is a conspicuous dark spot.

The radial forks in the wing are very long, the length of $R_{s}$ being half as long again as the distance between the radial fork and the insertion of the media. The antennæ are absent from the specimens at hand.

Male: Length $1.12 \mathrm{~mm}$.; length of forewing $1.1 \mathrm{~mm}$.; width 0.56 mm.; claspers (Pl. XXVII, fig. 9) $0.14 \mathrm{~mm}$.; hind tibiæ $0.32 \mathrm{~mm}$.; greatest width of genital segment $0.16 \mathrm{~mm}$.

Female: Length $1.4 \mathrm{~mm}$; length of forewing $1.4 \mathrm{~mm}$; width $0.672 \mathrm{~mm}$. Lingula of vasiform orifice very large, exserted, and rounded (Pl. XXVII, fig. 10).

\section{Aleurodicus (Metaleurodicus) minimus Quaintance.}

(Pl. XXVIII, figs. 1-10; Pl. XXIX, fig. 3.)

Alcurodicus minima Quaintance, Tech. Ser. 8, Dir. Ent., U. S. Dept. Agr., 1) $47(1900)$.

\section{ORIGINAL DESCRIPTION.}

Pupa-case.-Size about 1.17 by $0.71 \mathrm{~mm}$., subelliptical, many specimens are somewhat narrowed cephalad. Case usually widest across region of second abdominal segment. Color yellowish, varying to brownish. Empty case semitransparent, except for the irregular brown coloration on margin, and at the dorsal pores. Margins slightly crenulated, with very shallow indentures between the lateral wax tubes. There is no marginal rim. Just within the margin, all around, is a closely set row of short disk-like tubercles or papillæ, from which is produced a fringe of almost straight, tapering, glassy waxen rods from one-third to one-half as long as pupa-case is wide. On the more central dorsal region a light mealy waxen exudation may occur. Pupa-case slightly raised from surface of leaf by vertical fringe of wax, which usually remains attached to leaf on removal of dried specimens. On the dorsum, nearer the margin than center, is a row on each side of seven round and well-defined comnound pores. Considered transversely, these occur in pairs; a pair on cephalic segment; a pair on metathorax; three pairs along the abdominal segments, and two pairs in the region latero-caudad of the vasiform orifice. The caudal pair is somewhat the largest, with the cephalic pair next in size; the rest are sub- 
equal. These pores, individually, consist of a cylindrical, brownish-colored rim with a central, white, rod-like structure. On cephalic margin of case is a pair of setæ and a pair on the caudo-lateral region, a seta on each side. There is a pair of small, tubercled setæ just within caudal margin. Around the margin, just within the submarginal series of papillæ, is a row of small tubercled setæ, usually from 24 to 28 in all.

Vasiform orifice elongate-cordate; about three-fourths as broad as long; cephalic margin straight, caudal end bluntly rounded. Operculum subeliptical, cephalic margin straight, about one-third as long as orifice. Lingula usual, broad, extending quite to caudal end of orifice, bearing two pairs of setre distally. On rentral surface, rudimentary feet and antennæ quite distinct.

Adult ô.-Length, about $0 . \$ 6 \mathrm{~mm}$.; fore-wing, 1.1 by $0.52 \mathrm{~mm}$.; length of hind tarsus, $0.21 \mathrm{~mm}$; ; length of hind tibia, $0.38 \mathrm{~mm}$; length of hind femur, 0.26 mm.; color, yellowish white, with dorsum of thorax brownish. Eyes reddish, undivided, though with a pronounced constriction. Joint 1 of antennæe short, not one-half the length of second. Joint 2, narrow at base, truncate at distal end, widest centrally. Joint 3 long, longer than remaining joints tugether, distal joint ending in an attenuated process, bearing a terminal seta. Anterior tarsus about three-fourths length of posterior. Distal tarsal joint of first pair legs two-thirds length of distal joint of mentum. Wings slightly clouded around margin and with a very dilute oblique transrerse band centrally; at fork of distal branch of vein is a pronounced spot of brownish-black coloration, otherwise wings without spots. Margins of wings and the veins somewhat yellowish. Genitalia quite short for this genus; valves short and stout.

Adult \&.-Unknown.

This species approaches in some particulars quite close to Cockerell's iridescens, but it is much smaller, and the pupa-case differs in several particu. lars. It is quite similar also to Shimer's asarumis. His description is so meager that it will hardly be possible to locate his species unless, peradrenture, the type has been preserved.

Specimens received by the Division of Entomology at Washington, January 28, 1859, on "Guayaba," from A. Busck, Bayamon, Puerto Rico. Mr. Pergande remarks that quite a large number of the insects (pupæ?) had been killed by a very curious fungus. Div. Ent. No. 8422. Pupa-case described from numerous specimens; adult $\hat{\sigma}$ from two specimens.

Type-No. 14769, U. S. National Museum.

\section{Aleurodicus lacerdæ (Signoret).}

Aleyrodes lacerda Signoret, Bul. Soc. Ent. France (6) vol. 8, p. Ixiii (18S3).

This species, from the preliminary description given by Signoret, appears to be an Aleurodicus. It is impossible, however, from his remarks to place it definitely. Cotypes are supposed to exist in this country, but so far we have been unable to locate them. We therefore place the species here and quote his description.

\section{ORIGINAL DESCRIPTION.}

J'ai l'honneur, par l'entremise de notre collègue M. L. Fairmaire, de faire passer sous les yeux de la Societé des feuilles de l'Anonu sylvatica couvertes d'uné sécretion d'aspect cotonneux, ressemblant à de l'amiante et qui m'ont été envoyées par M. Antonio de Lacerda. Cette sécrétion abundante est due à 
la réunion d'un grand nombre d'Aleurodes soit à l'êtat de larve, soit a l'etat d'insecte parfait. J'indique les deux, car je pense que ces deux états conIribuent à cet amas de sécrétion par l'examen même de la forme particulière des diverses lamelles; les unes présentent comme des rubans, les autres comme des filaments, d'autres enfin de simples fils. L'insecte parfait est du double plus grand que l'Aleurodes chelidonii, jaunâtre, aves des macules brunes sur le prothorax; l'abdomen, entièrement jaune dans le mâle, offre deux plaques d'aspect particulier dans la femelle, celle-ci présentant un amas cotonneux d'aspect nacré et de forme bilobé de chaque coté de l'abdomen et sécrêté par les deux plaques rouges de l'extremité de l'abdomen. Devant donner une description complète de cette intéressante espèce, que je nommerai $A$. lacerda, je me contente de présenter aujourd'hui ces feulles vraiment extraordinaires car si l'on connaît déjà des espéces du genre Aleurodes sécrétant des matières ne se sont présentées en aussi grande quantité.

\section{[Translation.]}

I have the honor, through the agency of our colleague, Mr. L. Fairmaire, of exhibiting to the Society some leaves of Anona sylvatica covered with a cottony secretion resembling amiantus and which have been sent to me by Mr. Antonio de Lacerda. This abundant secretion is due to the union of a large number of Aleurodes, either larræ or adults. I mention the two, for I think from the examination of the peculiar form of the various wax plates that both states contribute to this mass of secretion; some of these appear like ribbons, others like filaments, and still others like simple threads. The mature insect is twice as large as Aleurodes chelidonii, yellowish, with brown maculations on the prothorax; the abdomen, entirely yellow in the male, shows, in the female, two peculiar looking plates; this presents on each side of the abdomen a bilobed cottony mass, pearly in appearance and secreted by the two red plates at the extremity of the abdomen. Before giving a complete description of this interesting species, which I will name $A$. lacerdce, I am contenting myself in presenting to-day these really extraordinary leaves, for, although species of the genus Aleurodes which secrete such material are already known, they do not show it in such great abundance.

\section{Aleurodicus phalænoides (Blanchard).}

(Fig. 11.)

Aleurodes phalanoides Blanchard, in Gay's Historia Física de Chile, Zool., vol. 8, p. 319 (1852).

This insect, so far as we know, has not been observed since it was described in 1852, and the description is too meager to show definitely its position. The form and venation of the wing as shown in fig. 11 are, however, those of Aleurodicus. The vertex, on the contrary, appears to be that of Dialeurodicus. When rediscovered, therefore. the insect may prove to fall in a genus older than Aleurodicus, but for 
the present we place it in that genus and quote herewith the original description:

\section{ORIGINAL DESCRIPTION.}

A. tota testaceo-rufa, antennis pedibusque pallidoribus; elytris albis opacis fasciolis duabus interruptis maculaque apicis pallide fuscis; alis totis albis. Long. corp., 1 lin.; extens. alar., $3 \frac{1}{4}$ lin.

Cuerpo enteramente de un testáceo bermejo $\mathbf{y}$ más ó menos salpicalo de blanco. Elitros muy grandes, opacos y adornados de dos fajas transrersales interrumpidas en el medio $\nabla$ hacia la punta por una mancha alargada de color moreno muy claro. Patas pálidas, lo mismo las antenas.

Este insecto es algo común en Santiago sobre las hojas del Parqui y principia a manifestarse en el mes de enero. Copiaremos aquí le que hemos notado en
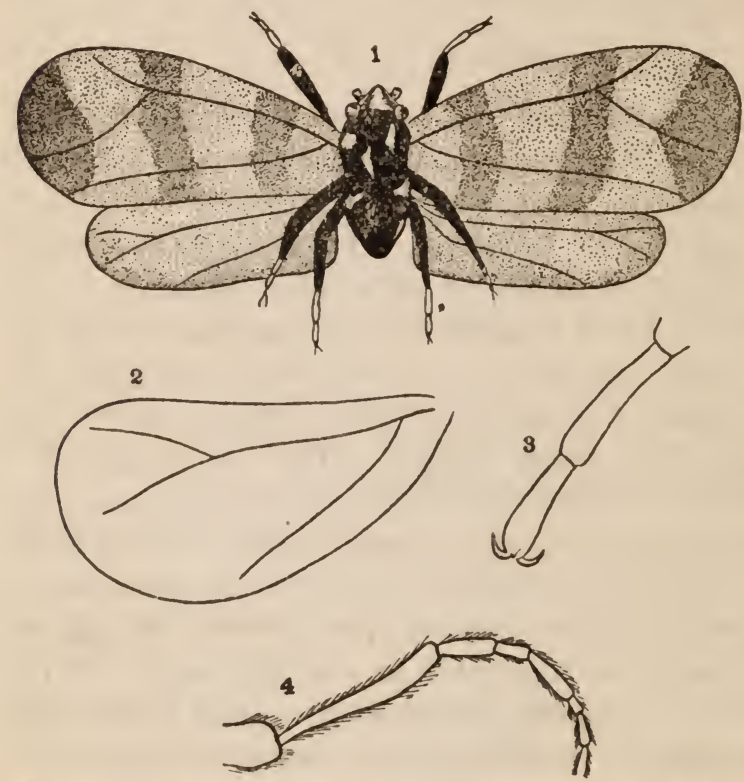

Fir. 11.-Aleurodicus phalanoiles: 1, Adult insect; 2, fore wing of adult; 3 , tarsus of adult; 4, antenna of adult (Redrawn from Blanchard.) nuestro diario sobre este animalito.

En la parte inferior de las hojas nueras del Farqui (Cestrum narqui), se observa una especie de mancha de $m$ verde ligeramente azulenco sembrada de muchos huevecitos perfectamente separados unos de otros, de (p. 320) forma ovalar, de color de tierra, alcauzando apenas un dozaro de lineas de diámetro. Poco después estos huevos cambian de color. vuelrense negruzcos con puntitos blancos, $\boldsymbol{S}$ observados entonces con $u$. lente de augmento se ve que con hembras adornadas con seis puntos dispuestos en dos filis, tres en cada una. Dichos

puntos pequeños y algonados grendecen a la par del animal, prineramente extendiendose del lado de la márgen que sobrepasan para formar una especie de membrana petañosa y recortada á modo de Bissus y en seguida hacia al centro, confundiendose entonces uno con otro para dar lugar a una masa informe, blanquista, algodonada y sembrada de pequeñasgotitas de un licor azucarado, muy apeticido de las hormigas que las visitan con mucha frecuencia. Los machos, provistos de grandes alas, se mantienen quietos, $\sigma$ si le mueven, cambian rara vez de lojas, pero meneando el arbusto, vuelan con precipitación y $\Omega$ poca distancia, por no poder sostener largo tiempo el vuelo. Paran principal. mente debajo de las hojas y son bastante comunes en la estacion del verano.

[Translation.]

Body entirely of a brownish testaceous and more or less variegated with black. Elytra very large, white opaque, and ornamented with 
two transverse bands interrupted in the middle apically with a large spot of very clear yellow. Feet pallid, like the antennx.

This insect is rather common in. San Diego on the leaves of parqui (Cestrum parqui) and infests this plant principally during the month of January. We reproduce here what we have noted about this little animal in our diary.

On the lower portions of the leaves of parqui a peculiar kind of spot was observed of light iridescent green, covered with many perfect eggs separated from each other, of oval form, earth color, measuring about one-twelfth of a line in diameter. A little later these eggs changed color, becoming blackish with white points, and we then observed with a magnifying glass that they were females ornamented with six dots arranged in two series, three in each one. These little dots bearing cotton threads vary with the size of the animal, extend from the side of the margin which they pass beyond to form a reticulated membrane like that of Bissus, and after that run to the center, uniting there with each other to form an irregular mass, whitish, covered with cotton threads, and showing little drops of sweetish liquid very acceptable to the ants which visit them very frequently. The males, provided with large wings, are sedentary, for if they move they rarely leave the leaf, but on jarring the bush they fly precipitately a little distance, but are not able to sustain flight for a long time. They generally inhabit the underside of the leaf and are rather common in summer.

\section{Genus PARALEYRODES Quaintance.}

Forewing with the radial sector and a small rudiment of the media retained; cubitus sometimes faintly indicated by a fold; vertex rounded; antennæ of four segments, of which the third is the longest; claspers of male short and stout; penis bilobed; paronychium of the foot represented by a long stout spine. Pupa case with a number of large compound wax pores of the type illustrated in Plate XXX, fig. 3 ; vasiform orifice with a very long, setose, spatulate, exserted lingula, which is armed with four long spines. Size small.

Type, persece Quaintance.

This genus is the most specialized one in the subfamily and represents the greatest reduction in wings and antennal segments. The two species may be separated as follows:

Species of Paraleyrodes.

A. Wings unmarked; thorax of pupa case with two stellate structures on the caudal part; two anterior pairs of abdominal compound pores often reduced urichii

B. Wings shaded with dusky; thorax of pupa without stellate structures; anterior abdominal pores normal persea 


\title{
Paraleyrodes perseæ (Quaintance).
}

\author{
(Plate XXX, figs. 1-9.)
}

Aleurodes persea Quaintance, 'Tech. Ser. s, Bur. Lut., U. S. Dept. Agr., p. 32. (1900.)

Paraleyrodes (Aleurodicus) persea, ${ }^{a}$ 'Tech. Ser. 12, Bur. Ent., U. S. Dept. Agr., p. 170. (1909.)

\section{The description of the species originally published in 1909 follows:}

Egg.-Elliptical, size about $0.24 \mathrm{~mm}$. by $0.12 \mathrm{~mm}$., with stalk unusually long; smoky in color, the shell smooth; eggs deposited promiscuously in the white, flocculent secretion of the adults.

Larva, first stage.-Size about $0.338 \mathrm{~mm}$. by $0.18 \mathrm{~mm}$., subelliptical, very slightly narrowed caudad; yellowish white, with more or less rectangular spots of orange in the abdominal regions, eye-spots reddish. There is a fringe all around of white wax; on the margin, cephalad of eyes, are six setx, and on lateral margins of thoracic region are three on each side. On caudal margin are six setre, the middle pair of which is considerably longer than others. On ventral surface, just within margin, all around, is a series of sparsely set, small, tubercled setæ. Legs and antennæ well developed. Vasiform orifice practically as in pupa-case.

Pupa-case.b_Size about $0.86 \mathrm{~mm}$. by $0.53 \mathrm{~mm}$. Subelliptical in shape, with slightly undulate outline. Color, under hand lens, yellowish brown: empty pupa-case colorless, very fragile, soon falling from the leaf. On the margin, all around, is a fringe of more or less curled, short, white wax ribbons, and over the case and adjacent leaf area are many fragments of white wax rods. of variable length, profusely produced from the seven pairs of dorsal compound pores, which are situated, a pair on cephalic end and six pairs on the abdominal segments, the cephalic two pairs of which are smaller and nearer the median line. The margin, or rim, of each compound pore is thickened, and from within the cup there arises a rather large, fluted, cylindrical tube, extending upward about one-half its. length beyond the rim of cup. Within tube, at base, is a short conical elevation. The entire structure is brownish in color. Dorsum void of well-developed setæ, save a pair just within caudal margin. A pair of minute setæ occurs on margin near caudal end of case. There is, however, just within margin on case, all around, a row of brownish-colored, tubercled setæ. Vasiform orifice subcordate (fig. $35, c$ ), about as long as widle. Cephalic margin straight, coinciding with cephalic margin of operculum. Operculum subrectangular, the latersl margins somewhat rounded; considerably wider than long and with caudal margin almost straight. Lingula relatively large,

a Extended and corrected from Tech. Ser. 8, Div. Ent., U. S. Dept. Agr., p. 32 (1890).

"In the description of the waxy secretion, as originally glven (1. c.), this was described as follows:

"There is a profuse dorsal exudation: Flrst, a rather short, downward-curving fringe of pearly whlte wax, all around, arising from just within margin and curling outward and downward over margin to near surface of leaf. Thls fringe is hardy continuous lut is more or less split apart into ribbons or bands. Second, more dorsally curving columns. These occur in a trlangle, one on each slde and one at end. These columns of white wax are about as high as pupa-case is wide. The pupa-case is almost obscured by this exudation, when viewed from above."

According to Doctor Morrlll's observations the secretion, as above described, is abnormal to this species and is due to the effect of parasltism. Of many specimens examined by him, showlng the secretion of this character, all were found to be parasitized; and, on the other hand, this type of secretion was never found on pupa-cases not attacked by parasites. The normal secretion therefore is as descrlbed in the text. 
[articularly distally, where it becomes broadly spatulate; longer than orifice, and bearing distally two pairs of seta. Abdominal segments moderately distinct. Rudimentary feet and antennie very evident.

Adult.-Body of living specimens buff or pinkish in color, marked with white. Wings whitish, but clouded with dusky. These are held almost flat along the dorsum, and do not meet along the middle line. A copious amount of floceulent white wax is secreted, which becomes scattererl over the leaf surface, the sluggish adults resting in little depressions here and there in the waxy covering. Antennæ peculiar and apparently of but four joints, due to the evident coalescence into two joints of the ringed segments 3 to 7 . In the forewing there is a single vein, as in Aleyrodes, with a rudimentary branch or fold near basal fifth and a very obscure rudimentary vein at very base of wing. Hind wings with but a single vein. Genitalia in male forcipate, penis bifurcate. Claws long and slender, with central spinous process. In female, length of body, 0.8 to $0.9 \mathrm{~mm}$.; length of forewing, 0.8 to $0.9 \mathrm{~mm}$.; width of forewing, 0.3 to $0.38 \mathrm{~mm}$.; length of antenna, 0.38 to $0.45 \mathrm{~mm}$. ; length of hind tibia, 0.25 to $0.3 \mathrm{~mm}$. Male proportionately smaller.

Food plants.-Orange, Persea carolinensis, persimmon (?), avocado pear. On orange this insect infests the older leaves, rarely or never occurring on the new growth as is the case with Aleyrodes citri.

Doctor Howard has given to the parasite of this species, reared by Doctor Morrill, the manuscript name Encarsia variegatus.

Type.-No. 14775 , U. S. National Museum.

Paraleyrodes urichii n. sp.

(Pl. XXXI, figs. 1-10.)

Received May 25, 1911, from Dr. F. W. Urich, Trinidad. The host is a species of Pithecolobium, and there were also present on the leaves two undescribed species of Aleyrodes. P. urichii differs from persece in its larger size and in having clear white wings, whereas in the latter species these are clouded.

DESCRIPTION.

Pupa case.-About $0.73 \mathrm{~mm}$. long by $0.51 \mathrm{~mm}$. wide; regularly elliptical in outline. (Pl. XXXI, fig. 2). As seen on leaf under hand lens (parasitized specimens only are available), the dorsum is quite convex, and the case is prominently raised from the leaf by a vertical fringe all around of white wax. Dorsum of case covered by a layer of dirty white wax, through which the compound wax pores and body segments may be fairly discerned. From the compound wax pores are produced the usual brittle wax rods, though this type of secretion in the present species is evidently meager. From the margin of case all around is a fringe of white wax more or less broken up into bands or ribbons, extending outward and downward, nearly or quite touching the surface of the leaf.

Under the microscope the color of the nonparasitized individual is yellow. The empty case is colorless. Parasitized specimens appear darker. 
Within the margin of dorsum of case all around is a series of spines, 12 or 13 on each side. Margin faintly crenulate (Pl. XXXI, fig. 5) though the marginal wax tubes are very obscure. On the dorsum are seven pairs of compound wax pores-one pair at cephalic end of case and six pairs on abdominal region. The two cephalic pairs of the abdominal series are about one-half the size of the others and nearer the median line; in these pores the cup is short, reaching scarcely above derm of case. The spinnerets occur in a circle at base of cup, and are not vertically extended into tubes as in many species of Aleurodicus. The central process is well developed and is broken up into some 8 or 10 separate rods (fig. 4). Mesad of each of the first and second pairs of abdominal wax pores is a group on each side of simple wax pores. Cephalad of each of the pores of the first pair of abdominal wax pores is an indistinctly stellate structure. These simple pores and stellate structure are discernible only in the colorless empty case.

Vasiform orifice (Pl. XXXI, fig. 3) broadly cordate, about as broad as long. Operculum about one-half length of orifice, broadly convex on caudal margin, the sides rounded. Lingula large, spatulate, partly exserted, bearing distally two pairs of spines, and minutely setose. On ventral surface rudimentary feet and antennce very evident.

Adult female.-Body about $0.85 \mathrm{~mm}$. long. Color yellow; legs and antennæ paler; wings white, unmarked (Pl. XXXI, figs. 6, 7). Forewing about $0.8 \mathrm{~mm}$. long by $0.33 \mathrm{~mm}$. wide; rudimentary media arising from $R_{\mathrm{s}}$ about basal one-sixth of length of wing. Length of hind tibia $0.3 \mathrm{~mm}$.; tarsal joints of hind legs subequal in length, together measuring about $0.17 \mathrm{~mm}$. Antennæ (Pl. XXXI, fig. 9) four-jointed, about $0.46 \mathrm{~mm}$. long, joint III considerably exceeding joint IV in length. Claws (P!. XXXI, fig. 10) long, slender, with spinous paronychium.

Male.-Not seen.

Type-No. 14776, U. S. National Museum. Described from several parasitized pupæ on leaves, numerous normal and parasitized pupæ in balsam mounts, and several adult females in balsam mounts.

\section{Subfamily Aleyrodina.}

In the members of this subfamily the media of the forewing is lost, but the cubitus is retained as a distinct vein in most genera. The radial sector forms the main vein of the wing, and radius ${ }_{1}$ may or may not be present. No compound pores are present in the pupa case, and the paronychium is broad and hairy.

Genera of tilf Aleyrodin A.

A. Forewing with radius, radial sector, and cubitus present_-_Alcurochiton.

B. Forewing with only radial sectur and cubitus present Aleyrodes.

C. Forewing with only radial sector present Neomaskcllia. 

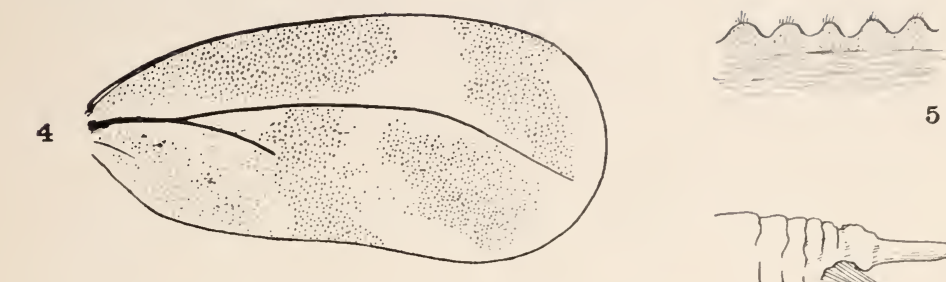

5
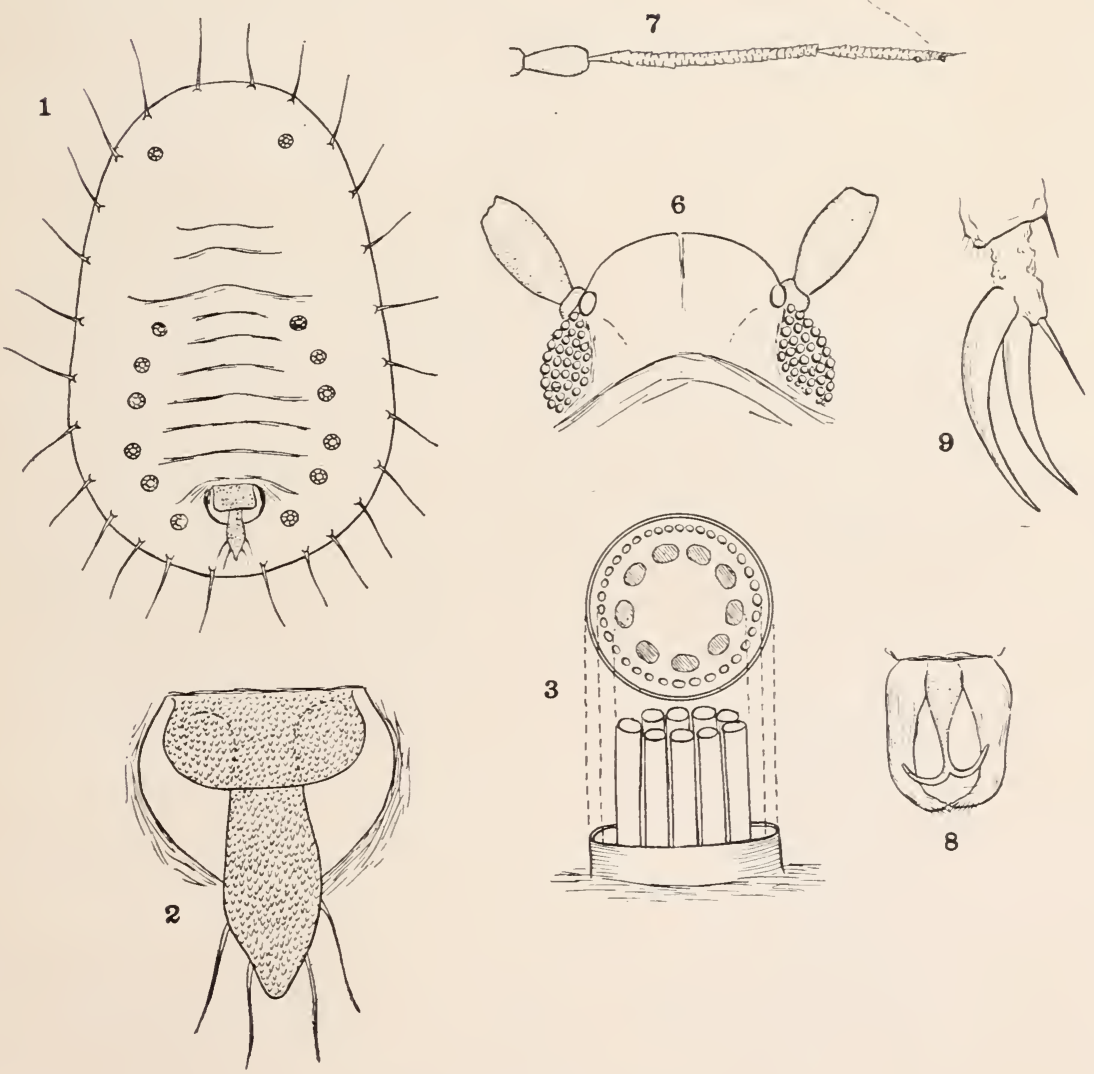

8

PARALEYRODES PERSEA.

Fig. 1.-Pupa case. Fig. 2.-Vasiform orifice of pupa case. Fig. 3.-Compound wax pore of pro - Fig. 4-Forewing of adult. Fig. 5.-Margin of forewing. Fig. 6.-Head of adult. Fig. 7.-Antenna. Fig. 8.-Male genitalia. Fig. 9.-Foot of adult. (Original.) 


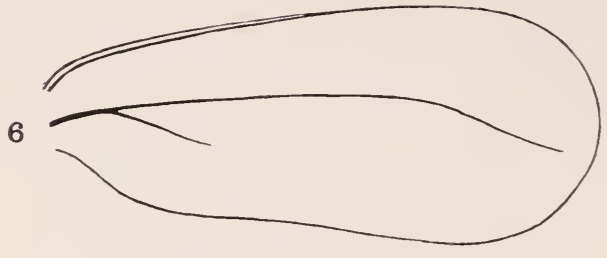

7 aratad

9
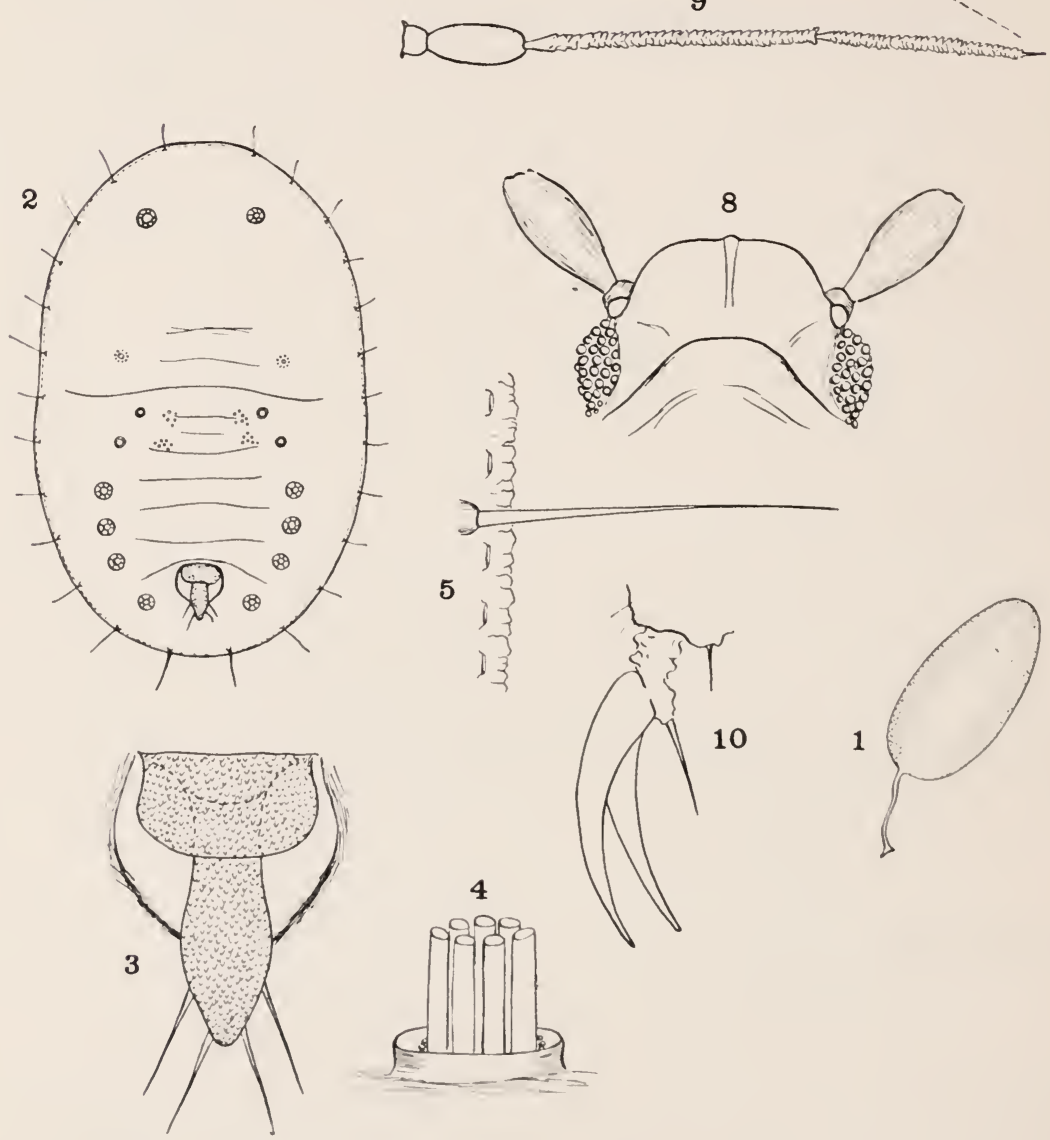

5
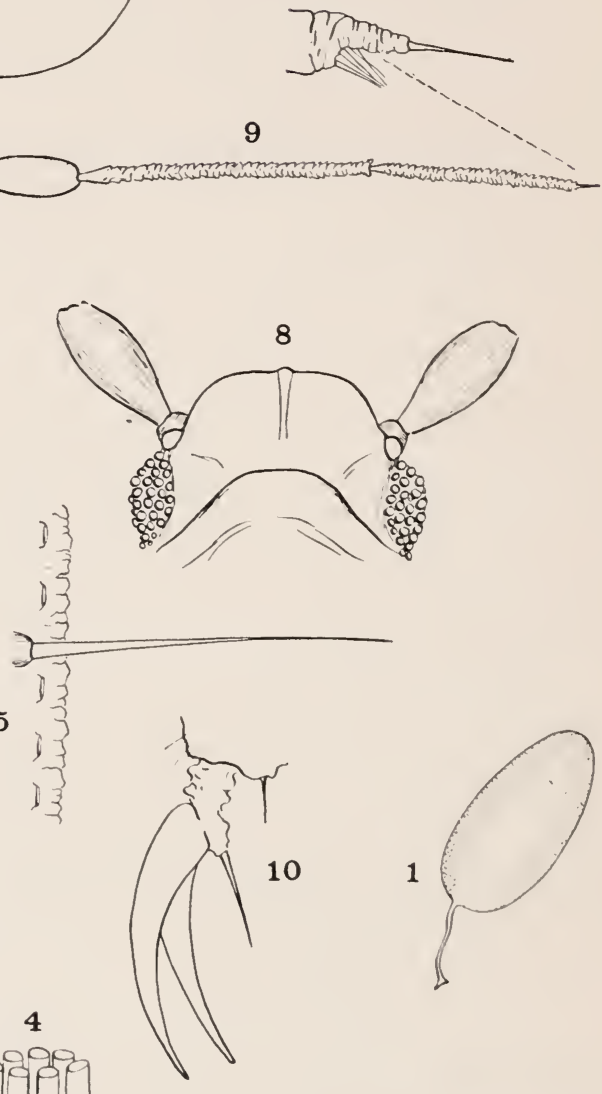

PARALEYRODES URICHII.

Fig. 1.- Eggg. Fig. 2.- l'upa case. Fig. 3.-Vasiform orifice of pupa case. Fig. 4.Compounti wax pore of pupa case. Fig. 5.-Margin of case. Fig. 6.-Forewing of adtult. Fig. 7. Costal mllargin of forewing. Fig. 8.- llead of adult. Fig. 9.Antentia of adult. (1)riginal.) 

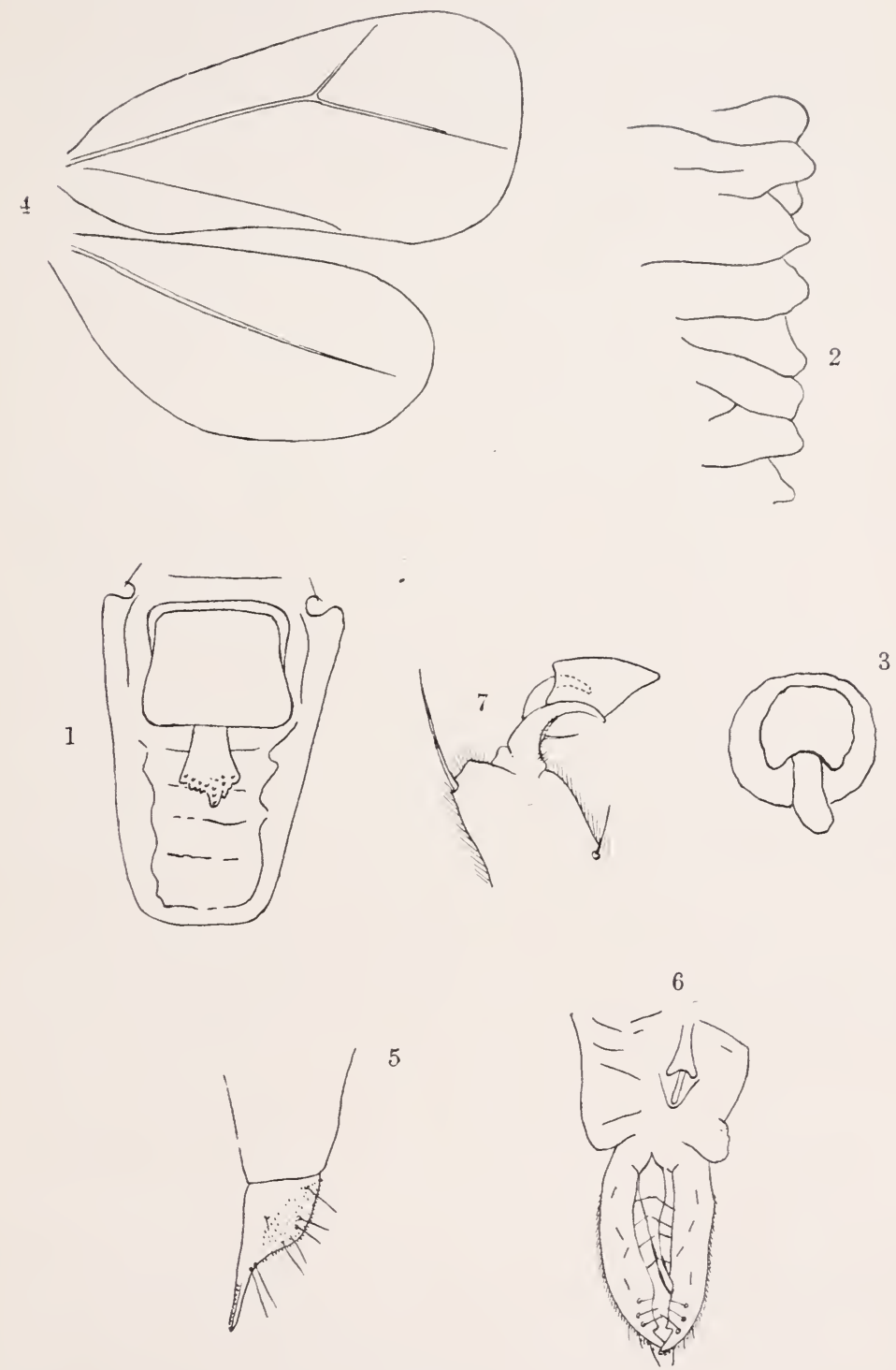

ALEUROCHITON ACERIS.

Fig. 1.-Vasiform orifice of pupa case. Fig. 2.-Margin of case. Fig. 3.- Vasiform orifice of adult. Fig. 4.-Wings of adult. Fig. 5.-Female genitalia. Fig. 6.- Male genitalia. Fig. 7.-Claw. (Redrawn from Tullgren.) 



\section{Genus ALEUROCHITON Tullgren.}

Forewing with radius ${ }_{1}$, the radial sector, and the cubitus retained; vertex rounded; antennæ of seven segments, of which the third is the longest; claspers of male of medium length and thickness; paronychium very large and hairy. Pupa case with no compound pores, but the dorsum crowded with simple ones. Iingula of vasiform orifice short, setose, and included; orifice surrounded by a differentiated area.

Type, aceris Geoffroy.

This genus is the most primitive in the Aleyrodinæ, and from it no doubt Aleyrodes arose by the reduction of radius ${ }_{1}$. It contains only two species, which may be separated as follows:

\section{Species of the Genus Aleurochiton.}

A. Paronychium in adult spatulate; vasiform orifice of pupa case large and subrectangular in outline. aceris.

B. Paronychium in adult long, blade-like, and hairy; vasiform orifice of pupa case subcordate in outline forbesii.

\section{Aleurochiton aceris (Geoffroy).}

(Pl. XXXII, figs. 1-6.)

Chermes aceris ovatus Geoffroy, Hist. Abr. des Insectes, p. 509 (1764). Aleurodes aceris Barensprung, Zeitschrift f. Zool., p. 176 (1849).

Aleurochiton aceris Tullgren, Ark. f. Zool., Bd, 3, No. 26, p. 15 (1907).

\section{ORIGINAI DESCRII'TION.}

Cette petite espèce est assez aplatie \& ovale. Elle est d'un brun clair, \& a dans son milieu une bande longitudinale brune foncée, aux deux côtés de laquelle sont des bandes de couleur blanche cendrée. Elle se trouve sur les fenilles de l'érable du côté du revers de la feuille.

Tullgren's description is the only complete one for this species that has appeared, and we quote it in full:

IMAGO.

Farbenzeichnung.-Die Exemplare, die dieser Untersuchung zu Grunde liegen, waren ein und halbes Jahr in Alkohol aufbewahrt. Sie sind alle einfarbig gelb, aber an der Spitze des Rostrums braunschwarz. Die Augen sind schwarzrot und die Flïgel einfarbig weiss.

Morphologische Merkmale-Weibchen.-Länge $1.79 \mathrm{~mm}$. Kopf ohne Mittelfurche, von der Seite gesehen $1 \frac{1}{2}$ mal so lang als breit. Augen lang und schmal nierenförmig, ungeteilt. Punktauge gross und deutlich, tangiert fast den Oberrand des Auges.

Die Antennen sind kürzer als Kopf und Thorax zusammengelegt. Das zweite Glied ist breit birnförmig, länger als das halbe dritte Glied. Dies ist $0.241 \mathrm{~mm}$. lang; lär zer als die folgenden zusammen. Glied IV $0.048 \mathrm{~mm}$., V $0.075 \mathrm{~mm}$.. VI $0.058 \mathrm{inm}$. und VII $0.051 \mathrm{~mm}$. lang. Die Glieder III-VII sind alle fein quer- 
unzelig und kurz behaart. Das siebente Glied an der Spitze mit einem feinen, ziemlich langen Borstchen. Die Glieder III,V-VII, mit kleinen Geruchsorganen.

Rostrum 3-gliederig. Das dritte Glied doppelt so lang und ein wenig schmäler als das zweite. Alle Glieder fein behaart und mit einzelnen kurzen Börstchen.

Scutellum triangelförmig, mit Längsfurche.

Die Beine sind ziemlich lang. Tibia I, $0.46 \mathrm{~mm}$., II, $0.53 \mathrm{~mm}$., III, $0.75 \mathrm{~mm}$. lang. Metatarsus I, $0.189 \mathrm{~mm}$., II, $0.172 \mathrm{~mm}$., III, $0.214 \mathrm{~mm}$. lang. Die Glieder besonders fein behaart und mit mehr oder weniger distinkt reihenförmig geordneten Stacheln. Tibia III wie bei Al. proletella, fragarice u. s. w. Klauen 2, kurz und so lang wie das Apikalborstchen des Tarsus. Das Paronychium gross, blatt- oder spatenförmig erweitert, fast doppelt so lang als die Klauen.

Flügel wie bei $A$ l. proletella gerandet. Länge $2.2 \mathrm{~mm}$., Breite $1.1 \mathrm{~mm}$. Die Mittelrippe Gleich hinter der Mitte gegabelt. Die Rippenzweige erreichen den Flügelrand. Die Submedianrippe lang und fein. Die Mittelrippe der Hinterflügel vollkommen einfach.

Abdomen gross, oval. Die vier Ventralplatten feiner retikuliert als bei $z$. B. Al. proletella. Das Operculum der Analöffnung ebenso lang wie breit, am Hinterrande ausgerandet; die Lingula ron der Länge des Operculums. Die Genitalanhïnge scharf zugespitzt.

Männchen.-Die Analöffnung kleiner mit längerem, schmälerem und mehr ausgerandetem Operculum. Der Penis ist nur wenig aufgebogen. Die Genitalanhïnge schwächer gebogen, am Ende klauenförmig zugespitzt und unter der Spitze mit einem kleinen, scharfen Zahn. Die Spitze trägt einige lange Börstchen.

Das Puparium gewölbt, eiförmig, am Vorderrande quer und am Hinterrande ein wenig ausgerandet. Die Rückenseite ist fast vollständig von einer weissen Wachskruste bekleidet. Nur die Analöffnung und zwei Flecken vorn sind immer nackt. In der Kruste sind auch feine Risse, die die Segmentgrenzen mehr oder weniger markieren. Wird die Kruste weggenommen, ist das Puparium braun, fein körnig und von einer unregelmässigen, netzförmigen Struktur, die von feinen, eingedrïckten Linien veiursacht wird. Die Segmentgrenzen sind nur längs der Mitte der Dorsalseite dentlich. Der Rand ist krenuliert. Längere und gröbere Börstchen fehlen vollständig. Dagegen sind eine Menge von kurzen und feinen Haaren über die ganzen Rückentliche ausgestreut. Die Analöffnung liegt in einer langgestreckten, fast triangelförmigen Vertiefung. Das Operculum, das ziemlich stark gewölbt ist, ist ungefähr quadratisch. Die Lingula, die nur wenig sichtbar ist, ist an der Spitze breiter und mit feinen Zähnen bewaffnet. Ihr fellen vollstïndig die langen für die Aleurodes Arten charackteristischen Börsten. Länge c. 1.7 mm., • Breite c. $1.3 \mathrm{~mm}$.

Entwickelte Tiere habe ich bei Slïfringe in der Provinz östergöthnd gefunden (2, VI; 1905); Puparia waren auf Ahornblattem auf dem Experimentalfelde bei Stockholm sehr allgemein (Nov. 1906).

[Translation.]

IMAGO.

Color.-The specimens which are here described had been preserved in alcohol for about a year and a half. Their color is entirely a uniform yellow. The end of the rostrum is brownish black. The compound eyes are blackish red, and the wings are of a uniform white color. 
Morphological characteristics-Female.-Length $1.79 \mathrm{~mm}$. Head without median suture; viewed from the side, one and one-half times as long as wide. Compound eyes long and reniform, not divided. Ocellus large and distinct, very nearly touching the upper margin of the compound eye.

The antennæ are shorter than the combined length of head and thorax. The second joint is broadly pyriform in shape; it exceeds in length the half of the third joint. The length of the third joint is $0.241 \mathrm{~mm}$., longer than all the succeeding joints combined. Joint IV $0.048 \mathrm{~mm}$.; joint V $0.75 \mathrm{~mm}$. ; joint VI $0.058 \mathrm{~mm}$.; joint VII 0.051 $\mathrm{mm}$. in length. Joints III-VII are all provided with fine crosswise wrinkles and with short hairs. The seventh joint is provided at its terminus with fine bristles that are rather long. Joints III, V-VII have small sensory organs.

Rostrum three-jointed. The third joint twice as long and a little more contracted than the second. All the joints provided with fine hairs and with short scattered bristles.

Scutellum triangular. provided with a longitudinal suture.

The legs are rather long. Tibia: Joint I $0.46 \mathrm{~mm}$; II $0.53 \mathrm{~mm}$; III $0.75 \mathrm{~mm}$. in length. Metatarsus: Joint I $0.189 \mathrm{~mm}$.; II 0.172 $\mathrm{mm}$.; III $0.214 \mathrm{~mm}$. in length. The joints provided with very fine hairs and with spines that are more or less distinctly arranged in rows. Third joint of the tibia more or less like that in Aleurodes proletella, fragaria, etc.; it has two claws, short and of the same length as the apical bristles of the tarsus. The paronychium is large, - extended in spatulate or foliate shape, almost trvice as long as the claws.

Wing bordered as in Al. proletella. Length $2.2 \mathrm{~mm}$. Width 1.1 $\mathrm{mm}$. The middle vein forked behind the middle. The main branch reaches the wing border. The submedian vein is long and delicate. The middle vein of the hind wing is unbranched.

Abdomen large, oval. The four ventral plates more finely reticulated than in Aleurodes proletella. The operculum of the anal aperture is as long as it is wide; its posterior margin sinuate. The lingula as long as the operculum. The genital appendages sharply pointed.

Male.-The anal aperture is smaller, the operculum is longer, more contracted, and more strongly sinuate. The penis is only slightly bent upward. The genital appendages are not so decidedly curved; their terminus is pointed with shape of a claw, and below the end there is a small sharp tooth. The terminus is provided with a few long bristles.

The puparium is arched, oval, slightly sinuate at the posterior margin, and also sinuate across the anterior margin. The dorsal side is almost completely covered with a white waxy crust. ' Only 
the anal aperture and two spots near the anterior margin are always naked. There are fine rents in the waxy crust, which more or less define the limits of the segments. If the crust is removed, the puparium appears brown, fine grained, and of an irregular reticulated structure, which is caused by fine lines that are impressed on the body. The limits of the segments are distinguishable only along the middle of the dorsal side. The margin is crenulate. There are no long and robust bristles present. On the other hand, there is a great number of short fine hairs scattered over the whole surface of the dorsum. The anal aperture lies in a long, extended, almost triangular pit. The operculum is strongly arched and approximately rectangular. The lingula is scarcely visible. broadening out at the end, and provided with fine teeth. The long bristles which are characteristic of the rarious species of Aleurodidæ are entirely wanting in this case. Length approximately $1.7 \mathrm{~mm}$., width about $1.3 \mathrm{~mm}$.

I have found adult specimens of this insect at Slafringe in the Province of Ostergotland, Sweden (June 2, 1905). Puparia were very common on the naple leaves of the experimental field near Stockholm (Nov., 1906).

\section{Aleurochiton forbesii (Ashmead).}

(Pl. XXXIII, figs. 1-9.)

Aleurodes aceris Forbes, 14th Rept. Ill. State Ent., p. 110 (1884) ; Bul. 45, U. S. Nat. Mus., p. 294 (1893).

\section{ORIGINAL DESCRIPTION.}

I have noticed for several years, a peculiar bark louse upon the leaves of the maple, but have not bred it until the present year. The fully developed pupal scale is oval in general outline, somewhat lyrate, broadest posteriorly, contracted in front of the middle. Margins entire, surface densely granulated. The color is chocolate, mottled with white, the white rarying in amount and tending to form three transverse bands. The central segmented area is usually irregularly mottled with white, and a quadrate patch, including the vent, is almost always brown; but, otherwise, the color may vary from nearly uniform brown to almost white. Outline sometimes slightly emarginate nosteriorly. Length, .095 of an inch; greatest width, .045; width at anterior fourth, 036.

'J'he imago is pale yellow throughout; legs and abdomen pale; wings milky white; rostrum black at the extreme tip; veins yellowish: first joint of the antemar scarcely longer than wide, the remaining joints filiform, the second nearly as long as the four following and about four times as long as the tirst, the fourth longer than the third, the third and fifth about equal, the sixth fusiform.

At Tamaroa, in southern Illinois, soft maple trees were found budly infested by this bark lonse, but elsewhere it has ocemred in only trivial numbers. There are apparently two broods of this species in a year, scales collected in Augnst, 1883, emerging April 10 to 24, 1854, and others, collecterl during the present 
summer, emerging August 4. From these larvæ several hymenopterous parasites belonging to the genus Elaptus escaped September 6 , the species of which is ayparently new.

Elaptus aleurodis, n. s. Plate XI, fig. 6. Female. Length .03 of an inch; the lead .005 inch; front wings .032 of an inch long and .001 inch wide; posteriod wings .0032 inch wide at the widest point; antenux as long as the head and whole body; scape stout, arcuate, rising to the top of the head, about as long as the three following joints, nearly smooth, as is also the second joint; remaining joints densely pilose; the club not jointed, as long as the three joints precerling; first joint obconic, second about the same length but narrower. Color black, surface shining, abdomen alutaceous, head and thorax punctured, antennæ yellow, legs entirely yellow, femora and tibixe of the middle and posterior legs black, their tarsi yellow.

Described from three specimens bred from Aleurodes aceris.

In 1893, Dr. W. H. Ashmead pointed out (Bul. 45, U. S. Nat. Mus.; p. 294) that Forbes's name was preoccupied by aceris Geoffroy, a European species, and proposed for this species the name forbesii.

In his excellent paper "Uber einige Arten der Familia Aleurodidx" (Arkiv fur Zoologi, Bd. 3, No. 26, p. 15̆, 1907), Dr. Tullgren has shown that the European species (aceris Geoffroy) really represents a new genus, for which he proposed the name Aleurochiton. The general similarity of the pupa case of forbesii to that of aceris suggested that the two forms were closely related if not identical, which supposition was the more strengthened for the reason that they have similar food plants. Although forbesii is fairly common on maple in the eastern United States, it is only recently that we have had opportunity to examine the adults of this insect. During the summer of 1910 , Dr. C. W. Hooker secured the adults in some numbers at Cranmoor, Wis., and also the following season, at Vienna, Va. Our species proves to belong to Aleurochiton, but appears to be distinct from aceris Geoffroy, as will be seen from the description which follows:

Aleurochiton forbesii is fairly common on Acer.rubrum, A. saccharinum, and A. dasycarpum, ranging from Georgia to New York, north into Canada and west to Wisconsin, Illinois, and Missouri. So far as we are aware the insect has never been so abundant as to cause injury to its host plants. The European member of the genus, however, has recently attracted attention by its injuries as shown by $\mathrm{Mr}$. Max Wolf in a lengthy article "Ein Beitrag zur Kentniss von Aleurochition aceris Geoffroy," etc., in "Centrallblatt fur Bakter, Parasiten Kunde, U. Infektions Krankheiten, Bd. 26, April, Zweite Abteilung, 1910, page 643 .

\section{DESCRIPTIVE REMARKS.}

Egg.-Length about $0.24 \mathrm{~mm}$. exclusive of stalk. Fusiform in shape, not quite one-third as wide as long; stalk about one-fourth length of egg. Color white, without markings, though the globu- 
lar contents are plainly visible: stalk dark brown, attached a little to one side.

Pupa case.-Size about 1.45 by $1 \mathrm{~mm}$.; seen from above ovoid in outline, narrower cephalad, the dorsum almost flat; rasiform orifice depressed. Case raised on a relatively high vertical fringe of dirty white wax, which varies in height according to age, in mature specimens reaching as high as two-thirds diameter of case (Pl. XXXIII, figs. 2 and 6). Dorsum covered with a plate of dirty white wax of a granular structure, the vasiform orifice being naked and the body segments more or less evident. There is a shallow and broad longitudinal depression in the wax plate, with an evident central keel. Denuded of wax plate, and examined under microscope, the outer - third of dorsum all around is seen to be of a coarsely granular structure, which is absent on the more central dorsal disk. (Pl. XXXIII; fig. 4.) The granular structures or markings in the derm vary greatly in size and outline, and are apparently wax-secreting in function. Margin of case deflexed (PI. XXXIII, fig. 5), ending in a rim all around of large wax tubes, which may be seen through the derm above; apparent margin of case crenulate, due to granulations above mentioned; on caudal margin there are three pairs of spines of which the central pair is strongest; color variable. Mature specimens in the fall are generally dark brown and blackish, with large, irregular, semitransparent spots in the derm, usually three on caudal end, three on cephalic end, and one on each side. There is also usually a similar spot just cephalad of vasiform orifice, and one on the first and second abdominal segments near median line. In the latitude of Washington, and probably elsewhere, there are two broods of pupæ each season; the insect winters in the pupal condition on the fallen leaves. Pupæ of the first or early summer brood are almost colorless and do not show the dark coloration above mentioned.

Vasiform orifice (PI. XXXIII, fig. 3) small, cordate, not quite as wide as long; sides and caudal margin rounded; lingula not extended beyond orifice, spatulate, the basal portion unusually thick and stout, minutely setose, and bearing distally a pair of spines. Extending caudad to margin of case from orifice is a broad and widening depression or furrow. On ventral surface the stubby, rudimentary legs are easily discernible; they are two-jointed, disklike at tips.

Adult (female).-Length about $1.5 \mathrm{~mm}$.; length of forewing (Pl. XXXIII, fig. 7) $1.7 \mathrm{~mm}$; width 0.8 to $0.9 \mathrm{~mm}$.; length of hind tibia $0.66 \mathrm{~mm}$. ; length of basal tarsal joint $0.15 \mathrm{~mm}$. : length of distal tarsal joint $0.107 \mathrm{~mm}$. ; antenna (fig. 8) $0.42 \mathrm{~mm}$. long; third joint $0.16 \mathrm{~mm}$. long; joints IV to VII inclusive $0.2 \mathrm{~mm}$. in length ; joint II' subpyri- 

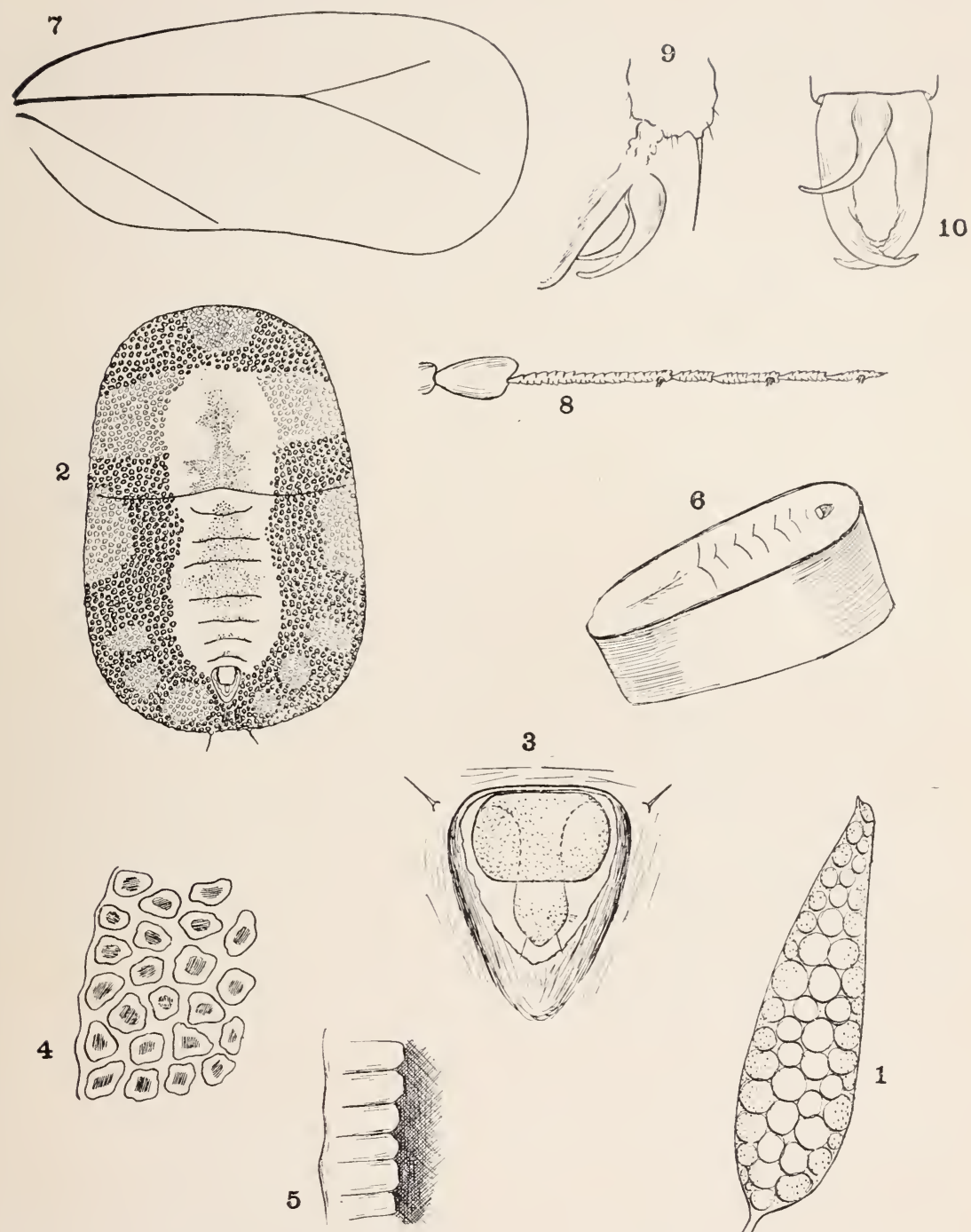

3
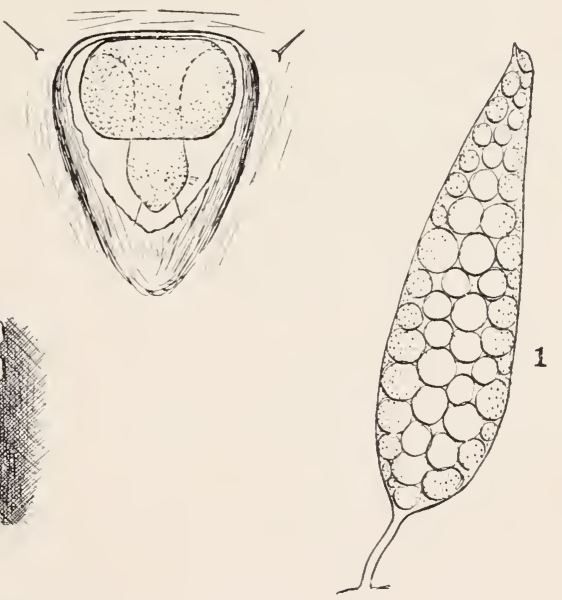

ALEUROCHITON FORBESII.

Fig. 1.-Egg. Fig. 2.-Pupa ease. Fig. 3.-Vasiform orifice of pupa case. Fig. 4.Margin of case and edge of dorsum. Fig. 5.-Margin of case, ventral view. Fig. 6.Pupa case, showing box-like nature. Fig. 7.-Forewing of adult. Fig. 8.-Antenna, Fig. 9.-Foot of adult. Fig. 10.-Male genitalia. (Original.) 


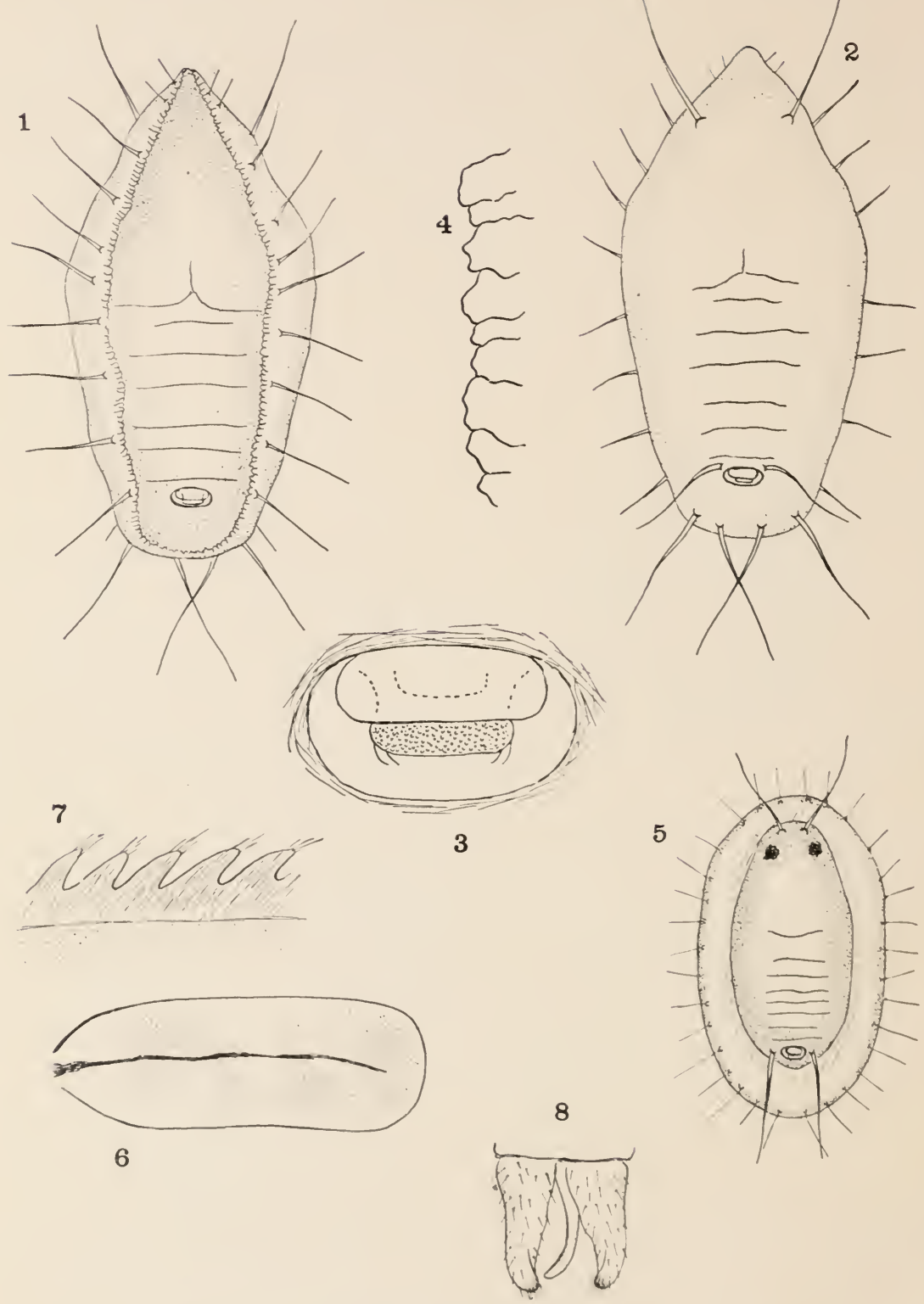

NEOMASKELLIA COMATA.

Fig. 1. - J'upa case, dorsal view. Fig. 2. - Sume, ventral view. Fig. 3.-Vasiform

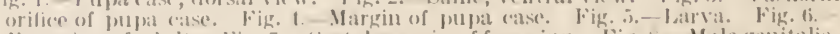

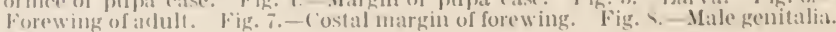
(Original.) 
form; joints III to VII slender; numerously ringed; joints IV and VI, and V and VII subequal in length; compound eyes reniform; large ocellus almost touching the compound eye near its upper margin.

General color of body yellow; legs and antenna paler; wings white, unmarked; venation typical for Aleurochiton; abdomen of gravid females large, distended with equally developed eggs, as many as 50 having been counted in one instance.

The so-called paronychium (Pl. XXXIII, fig 9) is blade-like, considerably longer than claws, and fringed on lower edge with hairs. In aceris this structure is spatulate and almost twice length of claws.

Adult (male).-A single specimen only of this sex is at hand; general structure as in female; genitalia forcipate (Pl. XXXIII, fig. $10)$, the valves rather short and stout, strongly curved at tip; penis enlarged at base and strongly curved.

Described from numerous pupæ on leaves, and pupæ, adult females, and one male in balsam mounts.

\section{Genus ALEYRODES Latreille.}

Forewing with radial sector and cubitus retained and a very small rudiment of the media rarely present ( $\mathrm{Pl}$. I, fig. 11) ; antennæ variaable, of seven segments, sometimes the third longest, sometimes the seventh; vertex rounded; paronychium of moderate length and hairy; claspers of the male usually short and thick. Pupa case with no compound pores, but with or without simple pores variously arranged; orifice variable, showing several different types.

Type, proletella Linné. This genus is the original one and upon it the family was erected. At present a great variety of forms are here included which, when carefully studied, will no doubt, as previously mentioned, necessitate the breaking up of the genus.

Genus NEOMASKELIIA n. gen.

Forewing with radial sector only present; antennæ of seven segments, of which the third is the longest; claspers of the male short, very hairy, and psyllid-like. Pupa case without compound wax pores and apparently few simple ones, but with numerous prominent spines; vasiform orifice of pupa case short, broad, and included.

Type, comata Maskell.

This genus is erected to include a species with the most reduced wing venation known in the family and with the claspers of male somewhat more primitive than the usual type. It would appear to be an early offshoot from the Aleurochiton branch.

$$
61201^{\circ}-13 \longrightarrow 7
$$


Neomaskellia comata (Maskell).

(P1. XXXIV, figs. 1-8.)

Aleurodes comata Mraskell. Trans. New Zealand Inst., rol. 28, p. 426 (1895).

Among Maskell's types are examples of the species described by him as Aleurodes comata. In examining these we find the species very different from other Aleyrodes and therefore describe and figure it in this connection. Maskell's original description is as follows:

\section{ORIGINAL DESCRIPTION.}

Eggs yellowish-brown, elliptical; length about $1 / 130$ in.; peduncle rather short.

Larva yellow, somewhat thick, flattish, regularly elliptical; length about $1 / 55$ in. Dorsum bearing four longish fine hairs, of which two are on the cephalic region and two close to the rasiform orifice. Margin entire, not thickened, bearing a row of rather long, strong hairs, sixteen on each side, and two shorter ones at the abdominal extremity. Rudimentary eres dark-red, tubercular, may be made out. Vasiform orifice broad, short, subelliptical; operculum short. transversely divided; lingula obsolete.

Pupa-case yellow; elliptical; length about $1 / 25$ in. The dorsal four hairs its in the larva, and there is usually a small quantity of dorsal white meal. Abdominal segments indistinct. Margin with wide shallow crenulations; marginal hairs as in the larva. Vasiform orifice, operculum, and lingula as in the larva. On turning orer the pupa-case the rudimentary feet, antemnæ, \&c., are clearly visible.

Aflult of general normal form; length of body about $1 / 30 \mathrm{in.}$ Head and thorax dark-yellow. Abdomen lighter yellow. Genitalia brown. Wings narrow, crey; nervure straight; the basal branch very short. almost obsolete: mar. gius of wings minutely serratulate, each serration bearing a minute spine; on the anterior edge of the hind wing are four rery fine hairs. The fore-wing bears four faint brownish patches difficult to distinguish; they form almost two transverse bands, but do not seem to meet at the nerrure. Genitalia of male and female normal; each arm of the forceps of the male bears a few shori hairs.

Hab. in Fiji, on a gramineous plant unknown to me. Mr specimens were sent l,y Mr. R. I. Holmes.

"This species may be distinguished by the marginal and dorsal hairs of the larra and pupa. Something similar may be seen in A. citri, Riley and Hownrd, us figured in Insect Jife, 1893, 1. 219, but that species has four cephalic and four yosterior long dorsil hairs; its wings are immaculate, and the adult male loars remarkable tufta of wax on the abdomen: the serrations of the wing margins are also different."

DESCRIPTIVE IREMARKS.

The larva (PI. XXXIV, fig. 5) is sufficiently characterized by Maskell.

Pupa case.-Size $0.88 \mathrm{~mm}$. by $0.1 \mathrm{~mm}$. Elongate oval, with attenuated cephalic portion (Pl. XXXIV, figs. 1,2). Edge of the case deflexed and armed with sixteen long spines and two pairs of small cephalic ones. Maregin irregularly crenulate or dentate (Pl. 
XXXIV, fig. 4). Dorsum armed with four pairs of very long spines, one pair on cephalic portion, one pair inserted before the vasiform orifice, and two pairs near the caudal margin. Vasiform orifice elliptical and transverse. Operculum of the shape indicated in Plate XXXIV, figure 3, its greatest width being $0.03 \mathrm{~mm}$. The exposed portion of the lingula is short, setose, and armed, with two pairs of spines.

Adult male.-The type slides of this species are dissections and of the adults only the wings and claspers are represented. The forewing ( $\mathrm{Pl}$. XXXIV, fig. 6) is $0.68 \mathrm{~mm}$. long and $0.24 \mathrm{~mm}$. wide, and is of almost an equal width throughout. The radial sector only is present, and it is irregularly thickened. Maskell figures another vein in the wing, but in the types it does not exist and the wing is also of a different form from other species in Aleyrodes. The costal margin is armed with curved teeth on which are small hairs (Pl. XXXIV, fig. T). The claspers (Pl. XXXIV, fig. 8) are unique. They are short, thick, hairy, and psyllid-like. The penis is almost equal in length to the claspers and slightly curved.

\section{ITTERATURE REFERRED TO IN TEXT.}

1. Plant Louse Aleyrodes. Bul. 96, Maine Agr. Exp. Sta., pp. 127 (1903).

2. Mémoires des Insects, vol. 2, p. 307 (1736).

3. The white fly or plant louse Alejrodes. Bul. 140, Conn. Agr. Exp. Sta. (1902).

4. The woolly white fly, Bul. 64, Part VIII, Bur. Ent., U. S. Dept. Agr. (1910).

5. Mededelingen van het Proefstation Oost. Java, New Series, No. 37 (1897).

6. White flies injurious to citrus in Florida, Bul. 92, Bur. Ent., U. S. Dept. Agr., pp. 57 (1911).

7. Notes on some Aleyrodes from Massachusetts, with description of new species. (a) Psyche, April, 1903. (b) Tech. Bul. No. 1, Mass. Agr. Exp. Sta., pp. 31-33 (1903).

8. Proc. U. S. Nat. Mus., vol. 27, p. 475 (1904).

9. Proc. Ent Soc. Wash., vol. 3, p. 24 ( 1895 ).

10. Kans. Unir. Sci. Bul., vol. 5, No. 9, p. 133 (1910).

11. Gardeners' Chronicle, p. 852 (1856).

12. The function of the rasiform orifice of the Aleurodidæ. Journal of the Asiatic Society of Bengal, vol. 72, part 2, pp. 6-7 (1903).

13. Arkir. f. Zoologi, Bd. 3, No. 26, p. 3 (1907).

14. Homologies of the wing reins of the Aphididæ, Psyllidæ, Aleurodidæ, and Coccidæ. Arn. Ent. Soc. Amer., vol. 2, p. 101 (1909).

15. Essai monographique sur les Aleurodes. Ann. Soc. Ent. France (4) vol. 8. p. 383 (1867).

16. Tideskrift for Landbrugets Planteral, p. 288 (1909).

17. Note on the Respiration of Aleyrodes citri. Can. Ent., vol. 33, pp. 173-176 (1901).

18. Udamoselis eine neue Aleurodiden Gattung. Zool. Anzeiger. Bd. 34, N. $7 / 8$, pp. 230-233 (1909).

19. Ann. \& Mag. Nat. Hist., ser. 7, vol. 8, p. 387 (1901).

20. Ent. Mo. Mag. (2) vol. 3, p. 32 (1892).

21. Tech. Ser. 8, Bur. Ent., U. S. Dept. Agr. (1900). 

